Deposits of Pre-1980

Pyroclastic Flows and Lahars from

Mount St. Helens Volcano, Washington

U.S. GEOLOGICAL SURVEY PROFESSIONAL PAPER 1444

2nd SET
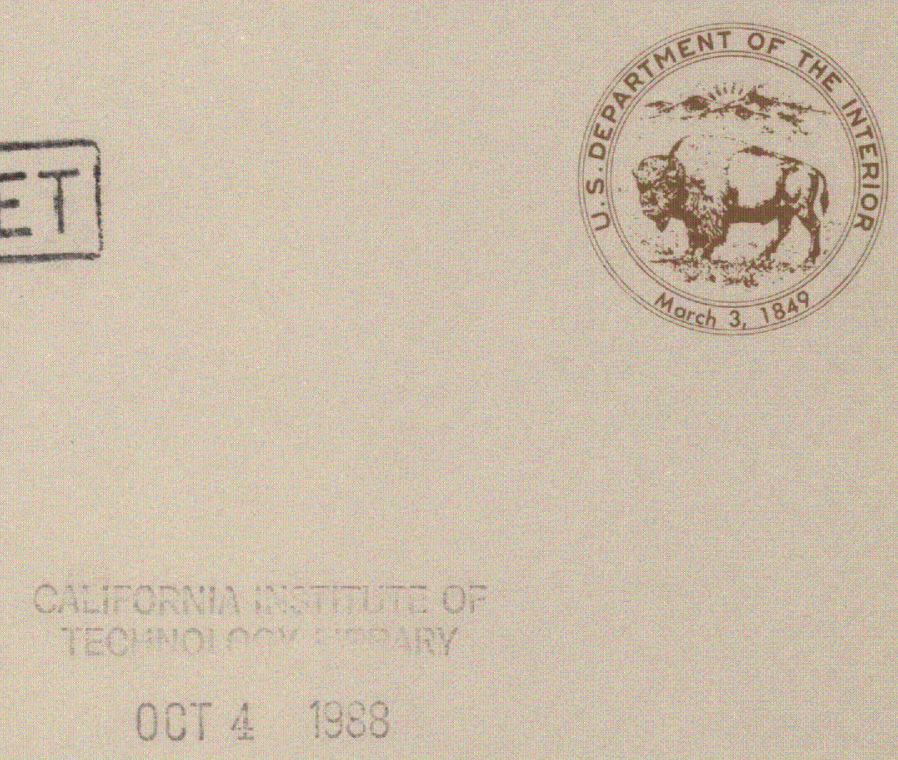

U.S. COVERNMENT DEPOSITORY 

DEPOSITS OF PRE-1980 PYROCLASTIC FLOWS AND LAHARS FROM MOUNT ST. HELENS VOLCANO, WASHINGTON 


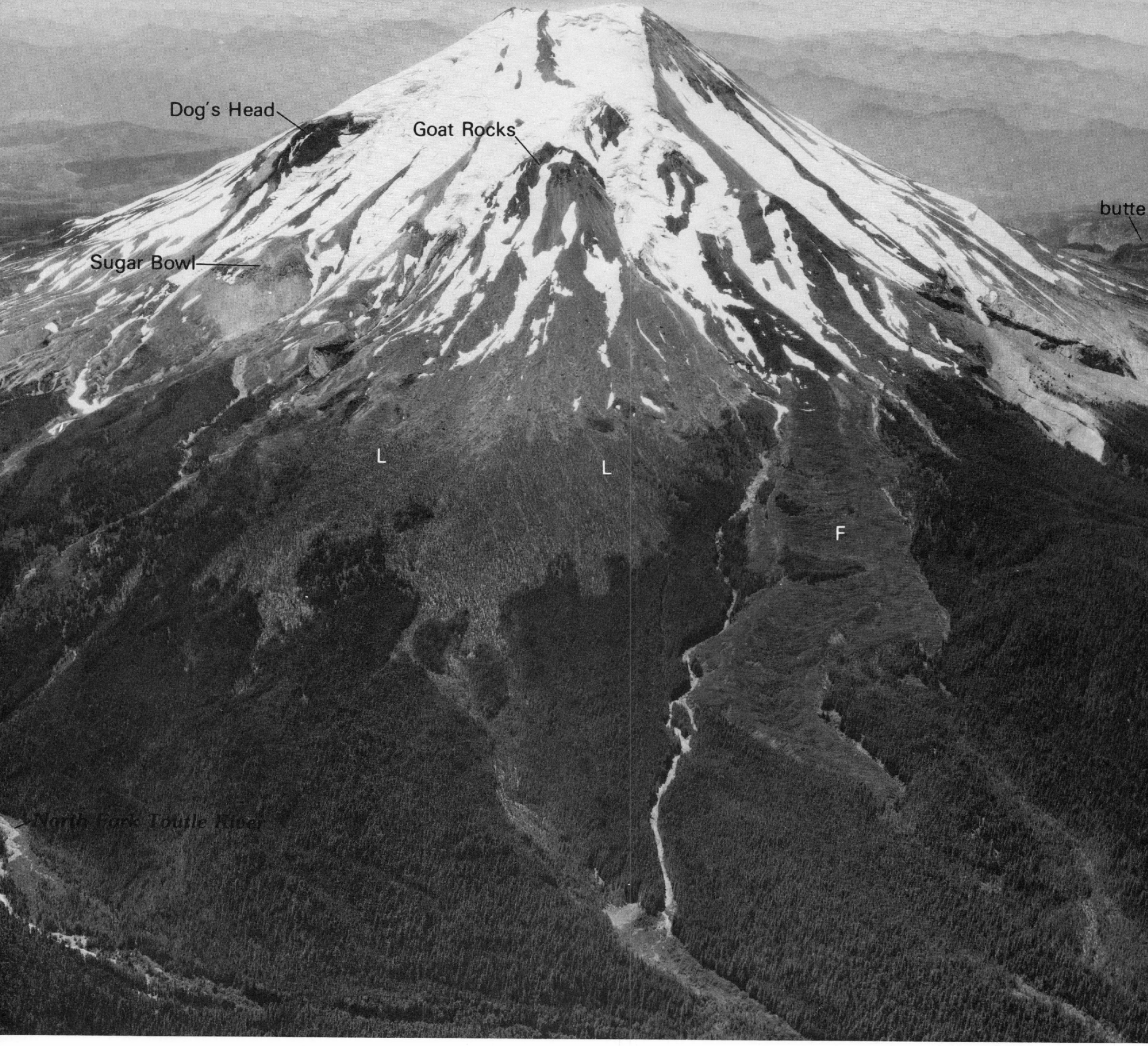

Frontispiece.-Aerial view of northwest side of Mount St. Helens showing "floating island" lava flow (F) and fan of lahars (L) downslope from Goat Rocks dome, all of which were formed during the 19th century. Copyrighted photograph by Delano Photographics. 


\section{Deposits of Pre-1980}

Pyroclastic Flows and Lahars from Mount St. Helens Volcano, Washington

By DWIGHT R. CRANDELL

U.S. GEOLOGICAL SURVEY PROFESSIONAL PAPER 1444

Lithology and stratigraphy of unconsolidated

deposits, other than air-fall tephra, formed

by eruptions during the past 40,000 years

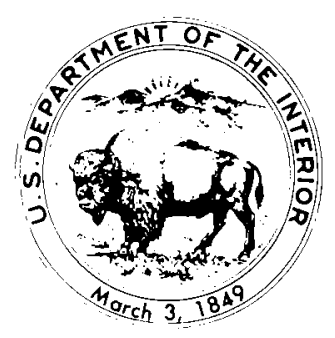




\section{DEPARTMENT OF THE INTERIOR}

DONALD PAUL HODEL, Secretary

\section{U.S. GEOLOGICAL SURVEY}

Dallas L. Peck, Director

\section{Library of Congress Cataloging-in-Publication Data}

Crandell, Dwight Raymond, 1923-

Deposits of pre-1980 pyroclastic flows and lahars from Mount St. Helens volcano, Washington.

(U.S. Geological Survey professional paper ; 1444)

Bibliography: p.

Supt. of Docs. no.: I 19.16:1444

1. Volcanic ash, tuff, etc.-Washington (State)-Saint Helens, Mount. 2. Lahars-Washington (State)-Saint Helens, Mount. 3. Geology-Washington (State)-Saint Helens, Mount. I. Title. II. Series: Geological Survey professional paper ; 1444.

QE461.C847 $1987 \quad 552^{\prime} .2^{\prime} 0979784 \quad 86-600117$

For sale by the Books and Open-File Reports Section, U.S. Geological Survey,

Federal Center, Box 25425, Denver, CO 80225 


\section{CONTENTS}

Abstract

Introduction

Topographic and geologic setting of the volcano

Hot dry flows of particulate material and associated ash clouds . . . . . . . . . . . . . . . . . .

Pyroclastic flows $\ldots \ldots \ldots \ldots \ldots \ldots \ldots \ldots \ldots$

Pyroclastic surges

Ash clouds

Lahars

Tephra

Methods used to date deposits

Summary of the eruptive history of Mount St. Helens

Deposits of pre-Mount St. Helens glaciations . . . . . . . . . .

Ape Canyon eruptive stage $\ldots \ldots \ldots \ldots \ldots \ldots \ldots \ldots$

Deposits . . . . . . . . . . . . . . . . . .

Nature and age of volcanism $\ldots \ldots \ldots \ldots \ldots \ldots \ldots$

Cougar eruptive stage

Deposits

South and southwest sides of the volcano

West side of the volcano

Southeast side of the volcano $\ldots \ldots \ldots \ldots \ldots \ldots$

Nature and age of volcanism . . . . . . . . . . .

Glacial deposits of Fraser age ..................

Swift Creek eruptive stage $\ldots \ldots \ldots \ldots \ldots \ldots \ldots \ldots \ldots$

Deposits

South side of the volcano $\ldots \ldots \ldots \ldots \ldots \ldots \ldots, 27$

West side of the volcano . . . . . . . . . . . . . 29

East side of the volcano $\ldots \ldots \ldots \ldots \ldots \ldots \ldots \ldots . \quad 30$

Southeast side of the volcano ............ 34

Nature and age of volcanism $\ldots \ldots \ldots \ldots \ldots \ldots \ldots \quad 36$

Spirit Lake eruptive stage $\ldots \ldots \ldots \ldots \ldots \ldots \ldots \ldots \ldots, 36$

Smith Creek eruptive period $\ldots \ldots \ldots \ldots \ldots \ldots \ldots \ldots$

Deposits ....................... 36

East side of the volcano $\ldots \ldots \ldots \ldots \ldots \ldots, \quad 38$

North side of the volcano . . . . . . . . . . . 40

Nature and age of volcanism $\ldots \ldots \ldots \ldots \ldots \ldots, \quad 41$

Pine Creek eruptive period $\ldots \ldots \ldots \ldots \ldots \ldots \ldots \ldots, 41$

Deposits ....................... $\quad 41$

Pine Creek valley ................. 44

Valleys of Coldspring Creek, Kalama River, and South Fork Toutle River

Valleys of North Fork Toutle River and Castle Creek

Nature and age of volcanism
Spirit Lake eruptive stage-Continued

Castle Creek eruptive period $\ldots \ldots \ldots \ldots \ldots \ldots \ldots \ldots$

Deposits ...................... 53

Pyroclastic-flow deposits and lava flows in and near the Castle Creek valley .............. 53

Lava flows on the north and northeast sides of the volcano

Pyroclastic-surge deposit in Ape Canyon ....

Dome on the east side of the volcano ........

Lahars and lava flows on the southeast side of the volcano $\ldots \ldots \ldots \ldots \ldots \ldots \ldots \ldots \ldots$

Deposits in the Kalama River valley ........

Lava flows on the south and southwest sides of

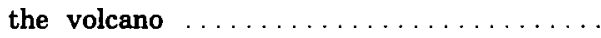

Nature and age of volcanism $\ldots \ldots \ldots \ldots \ldots \ldots \ldots$

Sugar Bowl eruptive period ............... 63

Fragmental deposits associated with the Sugar Bowl dome $\ldots \ldots \ldots \ldots \ldots \ldots \ldots \ldots \ldots \ldots, 64$

Air-fall tephra $\ldots \ldots \ldots \ldots \ldots \ldots \ldots \ldots, 64$

Ballistic fragments $\ldots \ldots \ldots \ldots \ldots \ldots \ldots, 65$

Wind-transported tephra .......... $\mathbf{6 5}$

Pyroclastic-flow deposits $\ldots \ldots \ldots \ldots \ldots \ldots, \quad 65$

Lahars .................... 66

Origin of the Sugar Bowl fragmental deposits ... 67

East dome $\ldots \ldots \ldots \ldots \ldots \ldots \ldots \ldots \ldots, \quad 67$

Kalama eruptive period $\ldots \ldots \ldots \ldots \ldots \ldots \ldots \ldots \ldots \quad 69$

Deposits of early Kalama age . . . . . . . . . . 69

Deposits of middle Kalama age . . . . . . . . . . $\quad 76$

Deposits of late Kalama age $\ldots \ldots \ldots \ldots \ldots \ldots, \quad 80$

Nature and age of volcanism . . . . . . . . . . . $\quad 82$

Glacial deposits of Holocene age . . . . . . . . . . 83

Goat Rocks eruptive period . . . . . . . . . . . . . . 84

Deposits .......................... 84

Tephra layer $\mathrm{T} \ldots \ldots \ldots \ldots \ldots \ldots \ldots \ldots, \mathbf{8 4}$

"Floating island" lava flow . . . . . . . . . . . $\quad 85$

Tephra erupted in $1842 \ldots \ldots \ldots \ldots \ldots \ldots, \quad 86$

Goat Rocks dome ............... $\quad \mathbf{8 7}$

Nature and age of volcanism $\ldots \ldots \ldots \ldots \ldots \ldots . \quad 88$

47 The future $\ldots \ldots \ldots \ldots \ldots \ldots \ldots \ldots \ldots \ldots \ldots$

References $\ldots \ldots \ldots \ldots \ldots \ldots \ldots \ldots \ldots \ldots \ldots \ldots \ldots$

Appendix A $\ldots \ldots \ldots \ldots \ldots \ldots \ldots \ldots \ldots \ldots \ldots \ldots$

\section{ILLUSTRATIONS}

Frontispiece. Aerial view of northwest side of Mount St. Helens

Plate 1. Map of Mount St. Helens and vicinity showing localities referred to in the text $\ldots \ldots \ldots \ldots \ldots \ldots \ldots$ In pocket

Figure

1. Location map of the Mount St. Helens region 
FIGURE 2-21. Photographs showing:

2. Disintegrating block of prismatically jointed dacite from the Goat Rocks dome $\ldots \ldots \ldots \ldots \ldots \ldots$

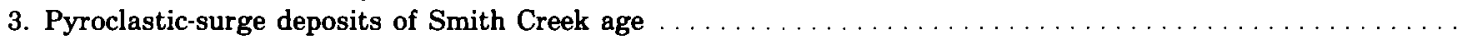

4. Beds of lithic ash of tephra set $\mathbf{C}$ overlying bouldery till of Hayden $\mathbf{C r e e k}($ ?) age $\ldots \ldots \ldots \ldots \ldots \ldots$

5. View west along lateral moraines of Hayden Creek(?) age

6. View to the west across the Smith Creek valley toward Ape Canyon and Mount St. Helens $\ldots \ldots \ldots \ldots \ldots$

7. Pumiceous pyroclastic-flow deposits of Ape Canyon age interbedded with air-fall tephra

8. Pyroclastic-flow deposit of Cougar age exposed in cut along Forest Road 90

9. Pyroclastic-flow deposit of Cougar age consisting of pumice blocks with almost no ash matrix

10. View westward of till of Fraser age exposed in cut along Forest Road 83

11. Till of Fraser age exposed along Forest Road 83

12. Bouldery till of Fraser age overlain by postglacial tephra upslope from a rock quarry in the Smith Creek valley

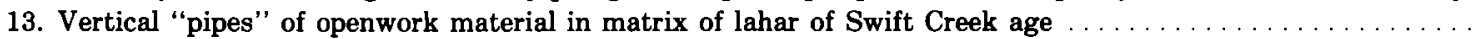

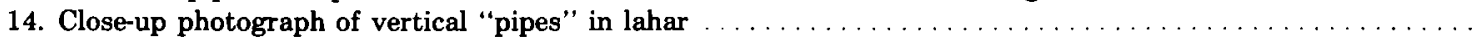

15. Interbedded lahars and pyroclastic-flow deposits of Swift Creek age $\ldots \ldots \ldots \ldots \ldots \ldots \ldots \ldots \ldots \ldots$

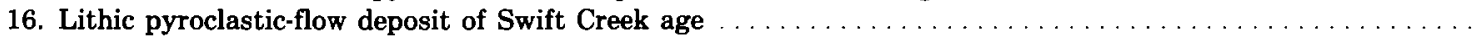

17. Aerial view northeastward across lower part of Ape Canyon

18. Lahar of Swift Creek age overlying tephra of set $\mathbf{S}$ and outwash sand and gravel of Fraser age $\ldots \ldots \ldots \ldots$

19. Deposits of a pyroclastic flow and a hot lahar of Smith Creek age

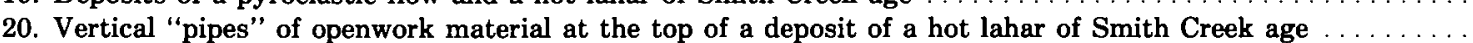

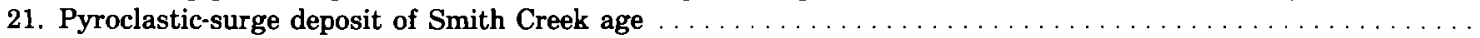

22. Sketch map showing inferred original extent of pyroclastic-flow deposits, lahars, and alluvium formed during

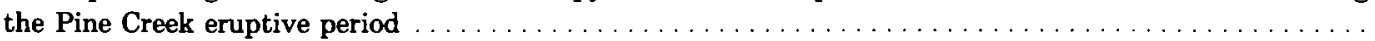

23-29. Photographs showing:

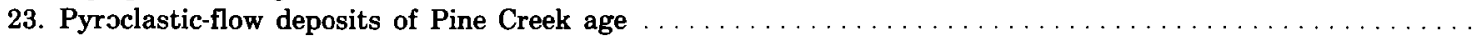

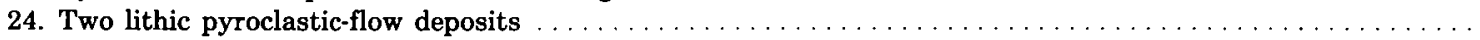

25. Two pyroclastic-flow deposits of predominantly lithic and pumiceous rock debris of Pine Creek age $\ldots \ldots$

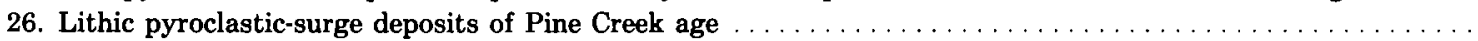

27. Crossbedded and planar-bedded ash deposits between pyroclastic-flow deposits of Pine Creek age $\ldots \ldots \ldots$

28. View northward toward the valley of Castle Creek

29. Lahars of Pine Creek age overlying a fluvial deposit and a lahar of Smith Creek(?) age

30. Sketch map showing inferred distribution of pyroclastic-flow deposits, lahars, fluvial deposits, and a dome of Castle Creek age

31-34. Photographs showing:

31. View north-northwest toward the north canyon wall of the South Fork Toutle River $\ldots \ldots \ldots \ldots \ldots \ldots$

32. View northeast toward the north canyon wall of the South Fork Toutle River $\ldots \ldots \ldots \ldots \ldots \ldots \ldots$

33. Lahars of Castle Creek age overlying a pyroclastic-flow deposit of Pine Creek age . . . . . . . . . . .

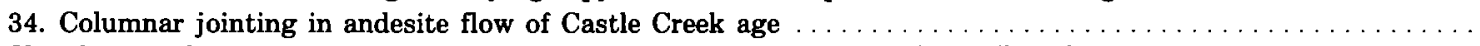

35. Sketch map showing inferred distribution of air-fall tephra and pyroclastic-flow deposits of Sugar Bowl age ...

36. Photograph showing pyroclastic-flow deposit resulting from a lateral blast from Sugar Bowl dome $\ldots \ldots \ldots \ldots$

37. Sketch map showing inferred original extent of lava flows, pyroclastic-flow deposits, dome, lahars, and fluvial deposits formed during the Kalama eruptive period

38-54. Photographs showing:

38. Two pyroclastic-flow deposits of Kalama age exposed in the walls of a gravel pit in the Kalama River valley

39. Pyroclastic-surge deposit consisting of lenticular beds of lithic ash

40. Horizontal lenses of pumice lapilli and blocks within a pyroclastic-flow deposit $\ldots \ldots \ldots \ldots \ldots \ldots \ldots$

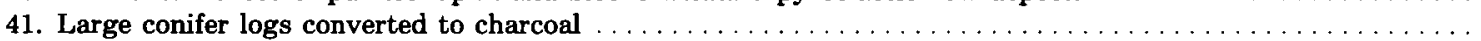

42. Vertical "pipe" from which fine-grained component of matrix of pyroclastic flow has been removed ......

43. Fluvial deposits of Kalama age that were derived from pyroclastic flows in the Kalama River valley ......

44. Aerial view of complex of andesite lava flows of Kalama age on the southeast side of Mount St. Helens ...

45. View northward across surface of pyroclastic-flow deposits of Kalama age southwest of Mount St. Helens .

46. Pyroclastic-flow deposit consisting of scoriaceous blocks of black andesite in an ash matrix ..........

47-54. Photographs showing:

47. Breadcrusted block of scoriaceous black andesite in pyroclastic-flow deposit of Kalama age ...........

48. View down "butte canyon" on southwest flank of Mount St. Helens showing pyroclastic-flow deposit of Kalama

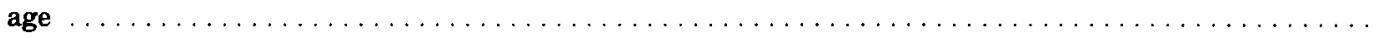

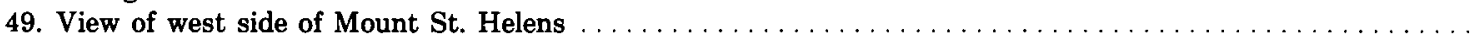

50. Aerial view of southeast side of Mount St. Helens showing fan of Kalama age $\ldots \ldots \ldots \ldots \ldots \ldots \ldots$

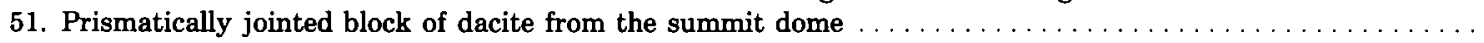

52. Lahars exposed in a pit near the confluence of the Muddy River and Smith Creek $\ldots \ldots \ldots \ldots \ldots \ldots$

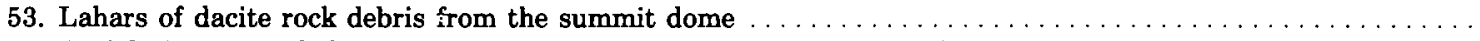

54. Aerial view toward the canyon of the South Fork Toutle River on the west side of Mount St. Helens ..... 


\section{TABLES}

TABLE 1. Comparison of vertical and horizontal distances (meters) traveled by some pyroclastic flows from Mount St. Helens

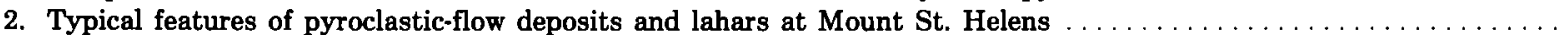

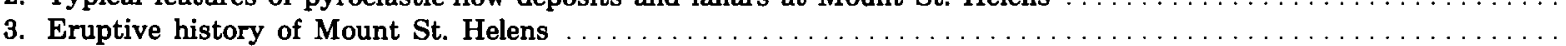

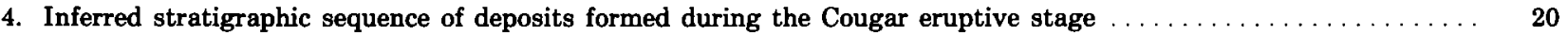

5. Stratigraphic sequence of deposits formed during the Swift Creek eruptive stage $\ldots \ldots \ldots \ldots$

6. Radiocarbon dates on samples that date or limit the ages of deposits of the Smith Creek eruptive period ...... 37

7. Radiocarbon dates on samples that date or limit the ages of deposits of the Pine Creek eruptive period ....... 42

8. Radiocarbon dates on samples that date or limit the ages of deposits of the Castle Creek eruptive period ...... 54

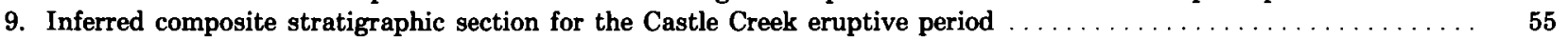

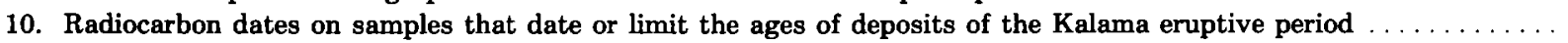





\title{
DEPOSITS OF PRE-1980 PYROCLASTIC FLOWS AND LAHARS FROM MOUNT ST. HELENS VOLCANO, WASHINGTON
}

\author{
By Dwight R. CRAndell
}

\begin{abstract}
Mount St. Helens in southern Washington has been one of the most active and most explosive volcanoes in the Cascade Range since its birth about 40,000 years ago. In this report its history is divided into four eruptive stages, the most recent of which is subdivided into six eruptive periods. Prior to 2,500 years ago the volcano erupted tephra, domes, and pyroclastic flows, but only a few lava flows that were large enough to extend beyond the base of the volcano. Most products of volcanism were dacite or silicic andesite. Eruptive behavior changed about 2,500 years ago, and since then the volcano has produced more mafic rock types as well as dacite.

The initial eruptions of the volcano were preceded by repeated glaciations of much of the Mount St. Helens region, most recently during the next-to-last glaciation when the Hayden Creek Drift was formed. The initial eruptions of Mount St. Helens during the Ape Canyon eruptive stage, which began sometime before 40,000 years ago and lasted until about 35,000 (?) years ago, produced lithic and pumiceous airfall tephra and pumiceous pyroclastic flows. The following Cougar eruptive stage began shortly before 20,000 years ago during the Fraser glaciation and produced tephra, pyroclastic flows, and a large lava flow of silicic andesite on the south side of the volcano. Lahars during the early part of the stage were followed by a large avalanche of rock debris from the south side of the volcano that extended as far as the Lewis River valley. Two pumiceous pyroclastic flows later crossed the Lewis River valley near the site of Swift Dam. During this eruptive stage, lahars and fluvial deposits formed a thick fill in the Lewis River valley southwest of the volcano. Subsequently, during the Fraser glaciation, alpine glaciers developed on the flanks of the volcano and in the adjacent mountains. At that time the largest glacier in the Mount St. Helens area extended down the North Fork Toutle River to a point about $27 \mathrm{~km}$ downvalley from Spirit Lake.

The Swift Creek eruptive stage began about 13,000 years ago, after the alpine glaciers had retreated or disappeared. Eruptive products of this stage include pumiceous air-fall tephra, both lithic and pumiceous pyroclastic flows, and lahars that partly filled valleys heading on the volcano. The Swift Creek stage ended sometime before 10,000 years ago, after which the volcano was dormant until about 4,000 years ago when explosive eruptions of the Smith Creek eruptive
\end{abstract}

period initiated the Spirit Lake eruptive stage. These eruptions produced large volumes of air-fall tephra as well as pumiceous and lithic pyroclastic flows. The Smith Creek eruptive period ended about 3,300 years ago and after a dormant interval of about 300 years was followed by the Pine Creek eruptive period which lasted until about 2,500 years ago. Small volumes of tephra were erupted during Pine Creek time, and repeated pyroclastic flows and lahars formed thick fills in valleys around the volcano. The Castle Creek eruptive period followed an apparent dormant interval of about 300 years. This period is distinguished by the initial appearance of significantly more mafic rock types than those of earlier stages and periods. Castle Creek time included, from older to younger, eruptions of andesitic lava flows, dacitic pyroclastic flows and tephra, andesitic lava flows, dacitic tephra, and basaltic tephra and lava flows. The period ended before 1,600 years ago and was followed by a dormant interval that apparently lasted about 600 years. It was interrupted by the extrusion of a dacite dome during the Sugar Bowl eruptive period. The extrusion of this dome at the north base of the volcano about 1,150 years ago was accompanied by lateral blasts, small pyroclastic flows, a small volume of air-fall tephra, and lahars.

The Kalama eruptive period began late in the 15th century, probably in A.D. 1480, with an explosive eruption of dacite tephra. This was accompanied and followed by lithic and pumiceous pyroclastic flows on the west side of the volcano and by other tephra eruptions. These early events were followed by the eruption of andesitic tephra, lava flows, and pyroclastic flows, after which the extrusion of a dacite dome formed a new summit of the volcano. Avalanches of rock debris from the dome spilled down all sides of the volcano to form lithic pyroclastic flows and lahars. The Kalama eruptive period ended about 350 radiocarbon years ago after a small pumiceous pyroclastic flow descended the northwest flank of the volcano. A subsequent dormant interval of about two centuries ended in A.D. 1800 when an explosive eruption of pumiceous dacite tephra initiated the Goat Rocks eruptive period. The next recorded eruption of that period produced an andesite lava flow northwest of the volcano, followed by the extrusion of the Goat Rocks dacite dome probably during the 1840 's. The last significant eruption of the period evidently occurred in 1857 . but several small steam explosions were recorded between 1898 and 1921. 
The early part of the Kalama eruptive period may be analogous to the dacitic eruptive activity that began at Mount St. Helens in 1980 with an explosive eruption followed by dome extrusion. If the current eruptive sequence repeats the events of Kalama time, future volcanic activity will include multiple eruptions of dacite in the form of domes, tephra, and pyroclastic flows, and andesite in the form of lava flows, tephra, and pyroclastic flows, and will continue intermittently for at least a century.

\section{INTRODUCTION}

Mount St. Helens lies in southwestern Washington about $70 \mathrm{~km}$ northeast of Portland, Oreg. The volcano is near the west margin of the Cascade Range at the heads of the Toutle and Kalama River valleys, about 10 km north of the Lewis River valley (fig. 1).

This report describes the character, origin, age, and extent of deposits of pyroclastic flows and lahars that were formed at Mount St. Helens before 1980, and their stratigraphic relations to other rocks and deposits of volcanic and glacial origin. Pyroclastic flows and lahars typically reach far beyond the base of a volcano, and, like tephra, commonly come to rest in places where they are readily preserved; indeed, some such deposits are the only remaining evidence of a period of volcanism. Not only are significant parts of a volcano's eruptive history recorded by pyroclastic flows and lahars, but the abundance of organic material characteristically preserved in the deposits makes the radiocarbon dating of volcanic events possible. These deposits are important parts of the stratigraphic framework on which other studies of a volcano and its products can be based. Pyroclastic flows and lahars also threaten life and property in their paths because of their high speeds, possible great thicknesses, and the high temperatures of pyroclastic flows. Thus an understanding of the modes of origin and extent of these phenomena in the past, gained from a study of their deposits, is important in forecasting hazards from future eruptions (Crandell and Mullineaux, 1978).

This study is part of a broader investigation into the pre-1980 geology of Mount St. Helens. Air-fall tephra erupted at the volcano before 1980 has been studied in detail by D. R. Mullineaux (U.S. Geological Survey); it is the subject of separate reports. The lava flows and domes, as well as some other eruptive products, have been mapped and studied by C. A. Hopson (University of California at Santa Barbara, 1971), who generously provided copies of his unpublished maps and other information during my study. R. P. Hoblitt (U.S. Geological Survey) is investigating stratigraphy and chemical variations of rocks produced at the volcano during the last 500 years, in an attempt to understand Mount St. Helens' behavior in sufficient detail to anticipate the character of future eruptions (Hoblitt and others, 1980).
Certain aspects of the volcano's eruptive activity have previously been discussed by Mullineaux and Crandell (1962, 1981), Crandell and Mullineaux (1973), Crandell and others (1975), Hyde (1975), and Mullineaux and others (1975), and hazards from future eruptions have been described by Crandell and Mullineaux (1978).

The chronology of eruptive activity at Mount St. Helens is based principally on 65 radiocarbon dates (Crandell and others, 1981), most of which (sample numbers preceded by the letter $W$ ) were determined in the radiocarbon laboratory of the U.S. Geological Survey in Reston, Va., under the supervision of Meyer Rubin. Rocks that are called dacite in this report contain at least 62 percent $\mathrm{SiO}_{2}$ and two or more of the following iron-magnesium silicate minerals: hypersthene, cummingtonite, hornblende, and biotite. These rocks typically are medium to light shades of gray and red. Mediumto dark-gray rocks with 54-61 percent $\mathrm{SiO}_{2}$ that contain hypersthene or augite or both, and perhaps minor olivine or hornblende, are called andesite. Very dark gray to black rocks with less than 54 percent $\mathrm{SiO}_{2}$ that contain abundant olivine are called basalt. Chemical analyses of some samples of rocks of Kalama age and older are given in appendix A, and additional analyses of rocks formed during the last 1,500 years are provided by Hoblitt, Crandell, and Mullineaux (1980). Ironmagnesium silicate minerals that are reported here as phenocrysts were concentrated from crushed rock samples by panning and bromoform separation. These minerals are described in each rock in their decreasing order of abundance.

This report is based mostly on field investigations between 1970 and 1974 . It was virtually complete before the current episode of eruptions began on March 27, 1980. Some deposits described here were buried by a debris avalanche and eruptive products on May 18, 1980, and may never be visible again. Other deposits, which were poorly exposed prior to 1980 , were stripped of their vegetative cover and eroded during the May 18 eruption, and they are now strikingly displayed in the banks of streams. I did not study these new outcrops comprehensively before completing this report. U.S. Geological Survey Professional Paper 1250 (Lipman and Mullineaux, 1981) provides details of the 1980 eruptions. The present report describes most localities on and around the volcano as they were prior to the eruptions of 1980 , and localities are so shown on plate 1 .

\section{TOPOGRAPHIC AND GEOLOGIC SETTING OF THE VOLCANO}

Mount St. Helens straddles a glaciated and deeply dissected divide of Tertiary bedrock between the 


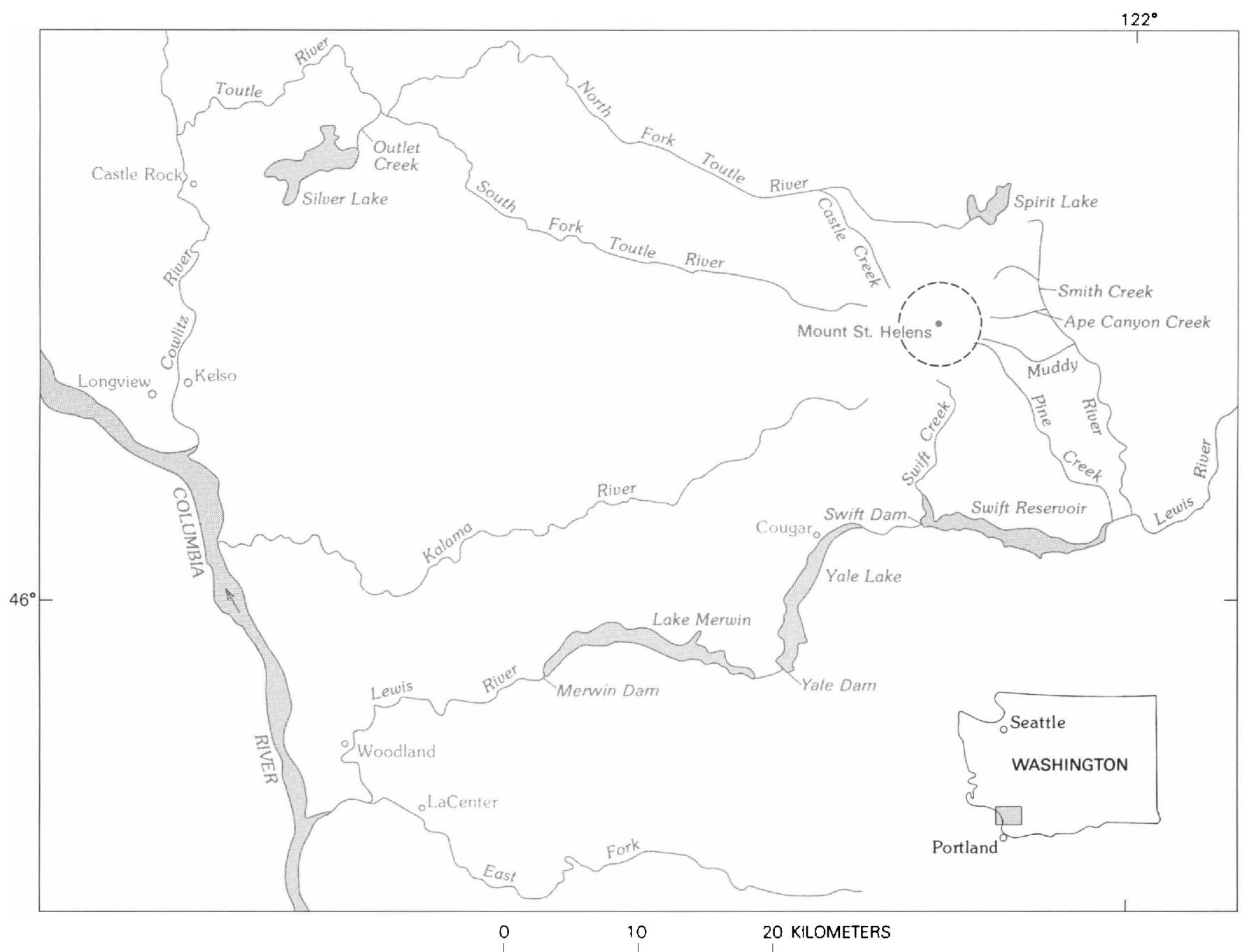

FIGURE 1.-Location map of the Mount St. Helens region. Dotted circle indicates a generalized outline of the base of the volcano.

west-trending valleys of the North Fork Toutle River and the Lewis River, but the base of the volcano is closer to the Toutle (about $3 \mathrm{~km}$ ) than to the Lewis (about 8 $\mathrm{km}$ ) (fig. 1). This divide probably reached altitudes of $1,200-1,500 \mathrm{~m}$ before the volcano appeared, and extended eastward from near the head of Castle Creek to the vicinity of Windy Pass. Thus, the pre-1980 summit of the volcano probably was only $1,400-1,700 \mathrm{~m}$ above the higher parts of its bedrock foundation. Drainage at the volcano extends southward to the Lewis River via the valleys of Swift and Pine Creeks, westward via the Kalama and South Fork Toutle Rivers, and northward via Castle Creek and several other tributaries of the North Fork Tbutle River. Each of these valleys contains a fill, now partly trenched by the rivers, of fragmental material derived from the volcano. The fill in the Kalama River valley includes at least two lava flows that have prevented deep dissection of the valley fill. Between the heads of the various valleys, the broad, outward-sloping fans that border the volcano are interrupted by bedrock ridges of the pre-volcano topography. Immediately east of the volcano, a north-northwest-trending bedrock ridge separates Mount St. Helens from the south-trending valley of Smith Creek and the lower Muddy River. The presence of the ridge evidently prevented large quantities of volcanic debris from entering the valley of Smith Creek and the Muddy River, so the floor of that valley is now some $200 \mathrm{~m}$ lower than the surface of the fill in the Pine Creek valley at a similar distance downstream from the volcano.

Mount St. Helens consists of two main parts. The younger part is the volcano we see today, which was mostly formed during the last 2,500 years. This volcano, whose base covers an area of about $80 \mathrm{~km}^{2}$, occupies the site of an older eruptive center, called "old Mount St. Helens" by Verhoogen (1937), which evidently first 
appeared sometime before 40,000 years ago and was intermittently active until about 2,500 years ago. The nature and size of this older volcanic center are not well known, but the character of many pyroclastic flows and lahars derived from it suggests that it consisted mostly of volcanic domes and short, thick lava flows. This interpretation is supported by the presence of remnants of old dacite domes that crop out in the walls of the present crater as high as an altitude of about $2,225 \mathrm{~m}$ on the east side and about $2,285 \mathrm{~m}$ on the west side (Hopson and Melson, 1982). The largest lava flow from the old center extends from a maximum altitude of about $1,825 \mathrm{~m}$ southward for $6 \mathrm{~km}$ to a point beyond the base of the volcano (C. A. Hopson, unpub. map, 1977). Debris derived from the "old Mount St. Helens" filled valleys around the periphery of the volcano, such as those of Swift and Pine Creeks, to depths of $100 \mathrm{~m}$ or more. This smoothed the pre-existing topography so that the modern cone was built on a broad, convex surface formed of fragmental deposits surrounding a central vent area occupied by remnants of domes and flows.

\section{HOT DRY FLOWS OF PARTICULATE MATERIAL AND ASSOCIATED ASH CLOUDS}

Hot dry flows of particulate volcanic rock mixed with gases include pyroclastic flows and pyroclastic surges, which are differentiated chiefly by their solid:gas ratios-flows have a higher proportion of particulate material during movement than do surges. Wohletz and Sheridan (1979) have suggested that a pyroclastic flow is a continuing stream of particulate material that maintains its kinetic energy over an extended period, whereas pyroclastic surges occur as a pulse or series of pulses of particulate material in which there is a rapid decrease of kinetic energy. The rapid loss of energy of pyroclastic surges is presumed to result from their relatively low mass. As pyroclastic flows and pyroclastic surges move away from a volcano, fine particulate material elutriated from them rises convectively to form ash clouds that can be carried downwind. These three processes of transport are discussed in the following sections.

\section{PYROCLASTIC FLOWS}

A pyroclastic flow is a hot dry flow of vesicular or nonvesicular rock fragments of diverse sizes that is mobilized by gravity and lubricated by intermixed air and other gases. Pyroclastic flows have a relatively high density and move along the bottoms of valleys or other depressions in contact with the underlying ground surface. The term is used here in a broad sense to include volcanic phenomena that have been called glowing avalanches, hot avalanches, nuées ardentes, pumice flows, ash flows, and block-and-ash flows.

Pyroclastic flows like those recorded by deposits at Mount St. Helens originate in many ways. First, pyroclastic flows of pumiceous or scoriaceous rock fragments can be formed when a gas-rich magma expands and disaggregates into ash and larger fragments. Masses of this fragmental material rise in the conduit, fill the crater, and then pour over the crater rim and down one or more sides of the volcano as an "emulsion" of particulate material and gas. Second, vertically directed explosions may expel fragmental material to form a column above the vent. Subsequent collapse of part or all of such a column can produce pyroclastic flows on one or more flanks of a volcano. Third, a laterally directed explosion can throw hot rock debris onto the sides of the volcano; the debris may then avalanche downslope and form pyroclastic flows. Fourth, pyroclastic flows of predominantly lithic ${ }^{1}$ material can originate from domes. The flanks of a growing dome typically are unstable, and avalanches of hot and cold rock debris can be triggered by explosions within the dome, by earthquakes, or by oversteepening of the dome's flanks.

Movement within pyroclastic flows has never been observed directly, but has been inferred both by analogy with debris flows mobilized by water and from sedimentary structures preserved in pyroclastic-flow deposits. In debris flows, experimental and field evidence and theoretical considerations indicate that an increase in concentration of dispersed solids results in greater viscosity and inhibits turbulence (Fisher, 1971, and references cited therein). Because of their high density, pyroclastic flows are more likely to move by laminar flow than by turbulent flow. Sparks (1976, p. 177) suggested that turbulence in a pyroclastic flow is most likely during its early stages when it is highly inflated and moving very rapidly, and that laminar flow develops as the flow deflates, viscosity and strength increase, and velocity decreases. A study of a pyroclastic-flow deposit by Wright and Walker (1981) indicated that while the flow had a high particle concentration, it moved initially by laminar flow, but then moved as a "semi-rigid plug" overriding a sheared basal layer as its solid:gas ratio decreased. They also inferred that the pyroclastic flow came to rest virtually instantaneously throughout its length.

Pyroclastic flows have been observed or inferred to move at speeds of many tens to more than $100 \mathrm{~km} / \mathrm{h}$. Velocities inferred for pyroclastic flows at Mount St.

\footnotetext{
${ }^{1}$ The term lithic refers to nonvesicular rock and is applied in this report to rock fragments of fresh, juvenile volcanic rock as well as fragments derived from the disruption of previously solidified volcanic rock.
} 
Helens, calculated from the height to which they rose on valley walls, range from $24-44 \mathrm{~m} / \mathrm{s}(87-160 \mathrm{~km} / \mathrm{h}){ }^{2}$ Such velocities are chiefly the result of gravity, although an initial high velocity may be provided by a laterally directed explosion. A high initial velocity can also be caused by the vertical fallback onto a volcano of a debris-charged eruption column.

The great mobility of pyroclastic flows, evidenced at Mount St. Helens by their ability to move distances of many kilometers on gradients as low as $35-50 \mathrm{~m} / \mathrm{km}$, is attributable to reduction of internal friction by several processes: (1) the emission of gas from rock fragments being transported, which acts as a lubricating agent together with an abundance of very fine ash ("rock dust"); (2) fluidization by upward-moving gases being released by rock fragments and by overridden and entrained air (Sparks, 1976, p. 170); and (3) the buoyant effect of dispersive pressures caused by interactions between rock particles ("grain flow" of Lowe, 1976). The moving mass is a dispersion of solid particles in gases; movement stops when escaping gases no longer adequately lubricate the mass or when the kinetic energy of the pyroclastic flow is exhausted. At Mount St. Helens the deposit of the longest known pyroclastic flow consists of nonvesicular material that ought not to have contributed much gas to the moving flow. Internal friction in such pyroclastic flows must have been minimized by entrapped and heated air and by the grain-dispersive effect.

It has been suggested (Francis and others, 1974) that the horizontal distance of movement for a given vertical drop is proportional to the volume of the flow and that many hot pyroclastic flows generated by the disruption of volcanic domes or lava flows on the steep flanks of volcanoes are no more mobile than avalanches of cold rock debris. Data for large avalanches of nonvolcanic origin have been tabulated by Lucchitta (1978). Twentytwo of these avalanches, with volumes of 150 million $\mathrm{m}^{3}$ or less (and roughly comparable to possible volumes of pyroclastic flows at Mount St. Helens), have distance of travel $(\mathrm{L})$ to vertical drop $(\mathrm{H})$ ratios of 2.5:1 to $5.9: 1$; they average $3.8: 1$ (table 1 ).

The relative mobility of some typical pyroclastic flows at Mount St. Helens can be compared by means of their $\mathrm{L}: \mathrm{H}$ ratios. It is assumed that pyroclastic flows formed during the last 2,500 years originated at a height of about $2,800 \mathrm{~m}$, which is about $150 \mathrm{~m}$ lower than the pre-1980 summit of the volcano, but some of these, such as the one represented by deposit no. 2 in table 1, probably originated well below $2,800 \mathrm{~m}$ rather than at or

\footnotetext{
${ }^{2}$ The minimum velocity required to move a mass upslope can be computed from the transformation of the kinetic energy of the flow into potential energy when the flow attained its maximum height. The resulting formula $(v=\sqrt{2 X \text { gravitational acceleration } X \text { height })}$ neglects frictional resistance.
}

near the summit of the volcano. The resulting $\mathrm{L}: \mathrm{H}$ ratios for five pyroclastic flows range from $4: 1$ to $5.9: 1$ and include flows of lithic material as well as those of pumice. These ratios are similar to those of some pyroclastic flows elsewhere in the world (Francis and others, 1974; Sparks, 1976). Comparable L:H ratios for some pyroclastic flows more than 2,500 years old cannot be determined as readily because the height of the volcano when the flows occurred is not known. However, if it is assumed that the source of the pyroclastic flows was at an altitude of about $2,300 \mathrm{~m}$, the $\mathrm{L}: \mathrm{H}$ ratios of two lithic pyroclastic flows and one consisting mostly of pumice are, respectively, 8.2:1, 9.5:1, and 7.6:1.

Pyroclastic flows that occurred during the last 2,500 years, when the volcano was nearly as high as it was before the 1980 eruptions, have $\mathrm{L}: \mathrm{H}$ ratios of less than 6:1 (table 1, nos. 1-4). It might be expected that the longer pyroclastic flows before 2,500 years ago (table 1 , nos. 5-7) were formed when the volcano was even higher. For example, a height of at least $3,400 \mathrm{~m}$ is implied for the source of a pyroclastic flow like that represented by deposit no. 6 , if the flow had a $\mathrm{L}: \mathrm{H}$ ratio of 6:1. However, no independent evidence exists that the volcano was ever as high as this, which suggests that the unusually long pyroclastic flows owed their mobility to factors other than the volcano's height. One way of increasing distance of movement is by providing a high initial velocity. This could be accomplished if a pyroclastic flow resulted from the collapse of a high eruption column. This mechanism has been proposed (Sparks, 1976; Sparks and Wilson, 1976) to explain the great mobility of some pumiceous pyroclastic flows, and it could also explain the length of pyroclastic-flow deposit no. 7, which consists chiefly of pumice. This explanation is less likely for voluminous pyroclastic flows of nonvesicular rock.

The pyroclastic-flow deposits described in this report are unwelded, unsorted to poorly sorted mixtures of clasts ranging in diameter from millimeters to several meters in diameter, set in a fine to coarse ash matrix. Although these deposits are not lithified, they range in consolidation from materials that slump to an angle of repose like that of loose sand to those compact enough to stand for years in vertical outcrops. The deposits are typically structureless, but some show crude planar layering of texturally or lithologically dissimilar materials. For example, some pyroclastic-flow deposits that are mostly lithic material contain horizontal lenses or layers of pumice blocks and lapilli at least a meter thick. Pyroclastic-flow deposits at Mount St. Helens range in thickness from less than $1 \mathrm{~m}$ to at least $15 \mathrm{~m}$, and they extend to distances from the volcano ranging from less than a kilometer to at least $18 \mathrm{~km}$. Lithic clasts in them are typically angular or subangular, and clasts of 
PRE-1980 PYROCLASTIC FLOWS AND LAHARS, MOUNT SAINT HELENS

TABLE 1.-Comparison of vertical and horizontal distances (meters) traveled by some pyroclastic flows from Mount St. Helens

\begin{tabular}{cccll}
\hline Pyroclastic- & Vertical & Horizontal & $\mathrm{L}: \mathrm{H}$ & Lithology \\
flow & drop & distance & ratio & \\
\hline deposit & $(\mathrm{H})$ & $(\mathrm{L})$ & & \\
\hline 1 & 1,950 & 8,500 & $4.4: 1$ & Pumiceous. \\
2 & 2,200 & 13,000 & $5.9: 1$ & One 1ithic, \\
3 & 1,980 & 8,000 & $4: 1$ & Scoria and 1ithic. \\
4 & 2,040 & 9,500 & $4.7: 1$ & Pumiceous. \\
5 & 1,590 & 15,500 & $8.2: 1$ & Lithic. \\
6 & 1,600 & 18,000 & $9.5: 1$ & Do. \\
7 & 1,730 & 15,500 & $7.6: 1$ & Pumiceous. \\
\hline
\end{tabular}

Age (table 3) and location of pyroclastic-flow deposits tabulated above:

1. Deposit of Kalama age in the Castle Creek valley.

2. Two deposits of Kalama age in the Kalama River valley.

3. Deposit of Kalama age near McRride Lake.

4. Deposit of Castle Creek age in the Castle Creek valley.

5. Deposit of Pine Creek age near the center of sec. 15, T. 7 N.,

R. 6 F., in the Pine Creek valley.

6. Deposit of Swift Creek age in the Muddy River valley.

7. Deposit of Cougar age on the south wall of the Lewis River valley.

pumice range from breadcrusted subangular blocks to rounded fragments. Some pyroclastic-flow deposits contain abundant blocks of breadcrusted scoria. In at least one such deposit, some of the blocks are stuck to one another, and others were plastically deformed while still hot after the pyroclastic flow had come to rest. Blocks of nonvesicular dacite or andesite in pyroclastic flows commonly exhibit radial prismatic jointing that has the appearance of a three-dimensional jigsaw puzzle. Such blocks tend to disaggregate along the joints into angular rubble (fig. 2). The matrix of lithic pyroclastic flows generally is a mixture of angular mineral and lithic fragments of silt and sand size, and the matrix of pumiceous pyroclastic flows contains abundant glass.

Pyroclastic-flow deposits can often be recognized by evidence of heat, such as (1) wholly carbonized wood, (2) a red or reddish-gray zone at the top of the deposit, (3) evidence of plastic deformation of individual clasts within the deposit after it was emplaced, (4) a preferred orientation of thermoremanent magnetism (TRM) in clasts, and (5) experimentally determined high emplacement temperatures of clasts.

The presence of carbonized wood suggests a pyroclastic-flow origin if it can be shown that the charring was caused by the enclosing deposit. The presence of hot rock debris in a deposit when it was emplaced is indicated by carbonized logs that are surrounded by a zone from which the silt- and sand-sized components of the matrix have been removed, or logs that have channels or "pipes" of fines-depleted matrix leading away from them. The steam or water expelled from the wood apparently carried away the fine components of the matrix and left the coarser material in an openwork fabric.

A common feature at the top of pyroclastic-flow deposits is a red or reddish-gray zone tens of centimeters to several meters thick. This color seems to result from oxidation of iron-bearing minerals during cooling of the deposits; it has also been attributed to the deposition by fumarolic vapors of finely divided 
hematite or magnetite (Williams, 1960). The presence of a reddened top is thought to be a reliable indicator of a pyroclastic-flow origin. However, this coloration is not present on all pyroclastic-flow deposits. At Mount St. Helens, some pyroclastic-flow deposits that underlie others lack red tops, perhaps because they were immediately buried by another pyroclastic flow that excluded oxygen.

The inference that clasts were hot when a pyroclastic flow came to rest can be tested by determining the direction of TRM in them with a magnetometer. If that direction is the same in all clasts, they must have cooled after the deposit was emplaced. A laboratory procedure can also determine, within certain limits, the actual temperature of emplacement, if that temperature was below the Curie temperatures of the constituent ferromagnetic minerals in the clast. This is done by heating oriented samples of clasts to progressively higher temperatures and recording changes in direction and magnitude of remanent magnetic vectors (Hoblitt, 1978; Hoblitt and Kellogg, 1979). An experimentally determined temperature of several hundred degrees Celsius or more in all clasts in a deposit suggests a pyroclastic flow as the transport mechanism. Deposits in which clasts show a wide range of emplacement temperatures, ranging from ambient to several hundred degrees Celsius, could have been formed either by pyroclastic flows or by lahars carrying hot rock fragments (Hoblitt, 1978; Hoblitt and Kellogg, 1979).

\section{PYROCLASTIC SURGES}

A pyroclastic surge is a relatively dilute flow of mostly fine particulate material and gases. The kinetic energy of a surge can be provided directly by the eruption that produced it and by gravity. Pyroclastic surges are characterized by turbulent movement and can attain speeds similar to those of pyroclastic flows. Surges typically hug the ground because they are denser than air, but the extent to which they are controlled by gravity depends on their speed and density and the amount of relief they encounter.

Pyroclastic surges can result from the ejection of fine material directly from a crater (Taylor, 1958) and its subsequent movement down the flank of a volcano,

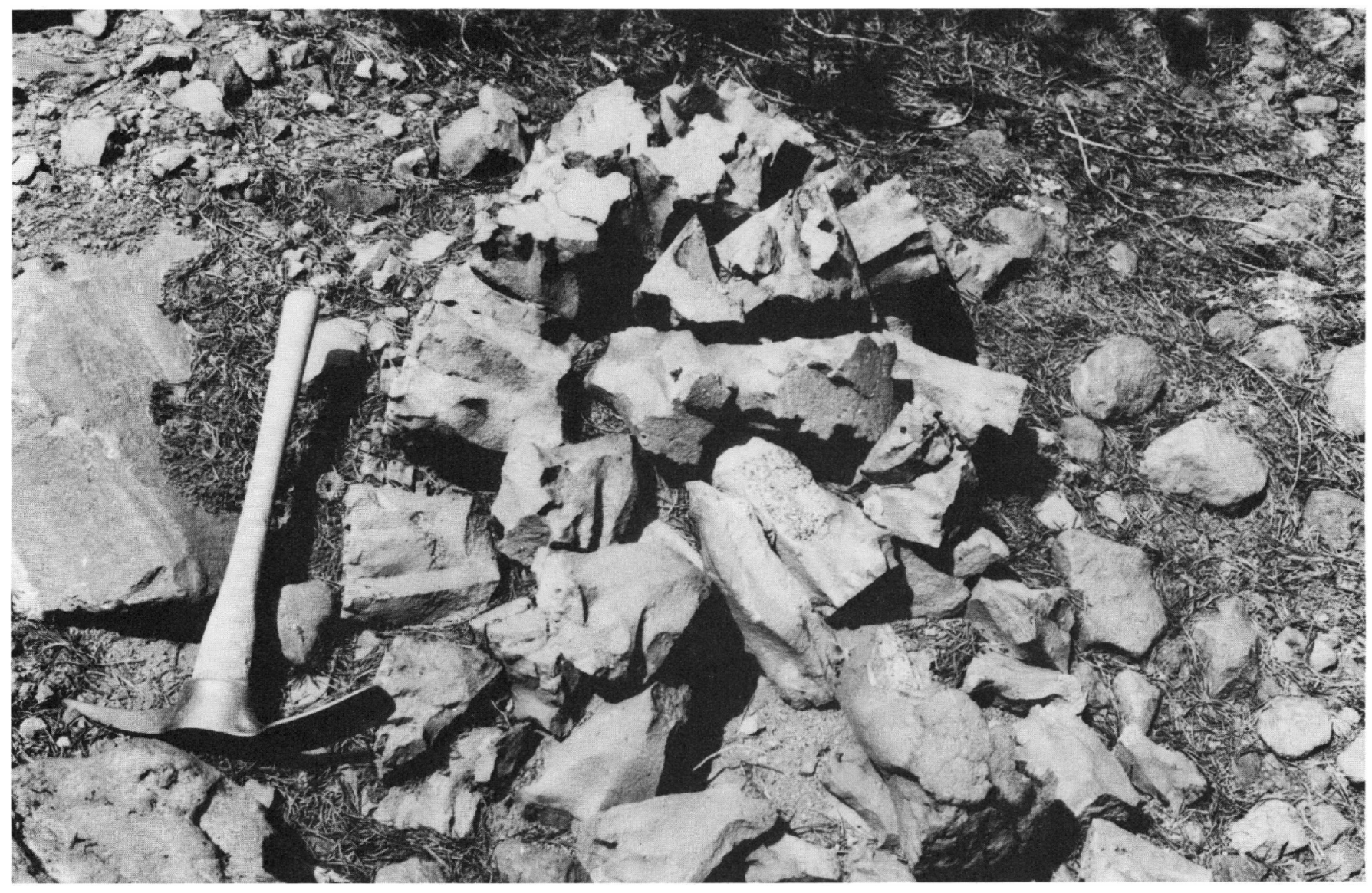

FIGURE 2,-Disintegrating block of prismatically jointed dacite from the Goat Rocks dome. 
from the fallback of a vertical eruption column, from a laterally directed explosive blast like that of May 18, 1980 , at Mount St. Helens, and probably in other ways. Those that are produced by column collapse may precede, accompany, and follow pyroclastic flows derived from the same eruption column, and material elutriated from a moving pyroclastic flow may itself become a pyroclastic surge (Fisher, 1979; Fisher and others, 1980; Fisher and Heiken, 1982).

Pyroclastic-surge deposits described in this report are generally less than $1 \mathrm{~m}$ thick and consist of well-stratified ash and small lapilli. These deposits are planar bedded or crossbedded, or both; and individual beds typically are lenticular (fig. 3). Some surge deposits are mostly lithic material; others are mixtures of lithic and vesicular fragments. Some pyroclastic-surge deposits are interbedded with air-fall tephra, others with pyroclasticflow deposits, and still others are associated with deposits thought to be of ash-cloud origin.

\section{ASH CLOUDS}

The term ash cloud (Crandell and Mullineaux, 1973) is used in this report to describe the clouds of ash that are elutriated from and accompany pyroclastic flows and pyroclastic surges. Ash clouds may rise convectively many hundreds of meters above the flow or surge from which they are derived. As the clouds cool, ash falls to the ground at various distances from the source depending on particle size and density and on windspeeds. Ashcloud deposits commonly blanket topography adjacent to and downwind from pyroclastic flows. They are much less extensive, however, than are layers of air-fall tephra of similar thickness, probably because of the more limited heights reached by ash clouds. Ash-cloud deposits consist mostly of fine to coarse ash, although some contain lapilli at heights of tens of meters above the probable tops of the associated pyroclastic flows. Ash-cloud deposits typically are massive and show no well-defined vertical variations in texture. The lack of well-defined bedding suggests rapid deposition from a stationary or slowly moving ash cloud.

\section{LAHARS}

A lahar is a flowing mass of unsorted or poorly sorted volcanic rock debris, mixed with water, that originates

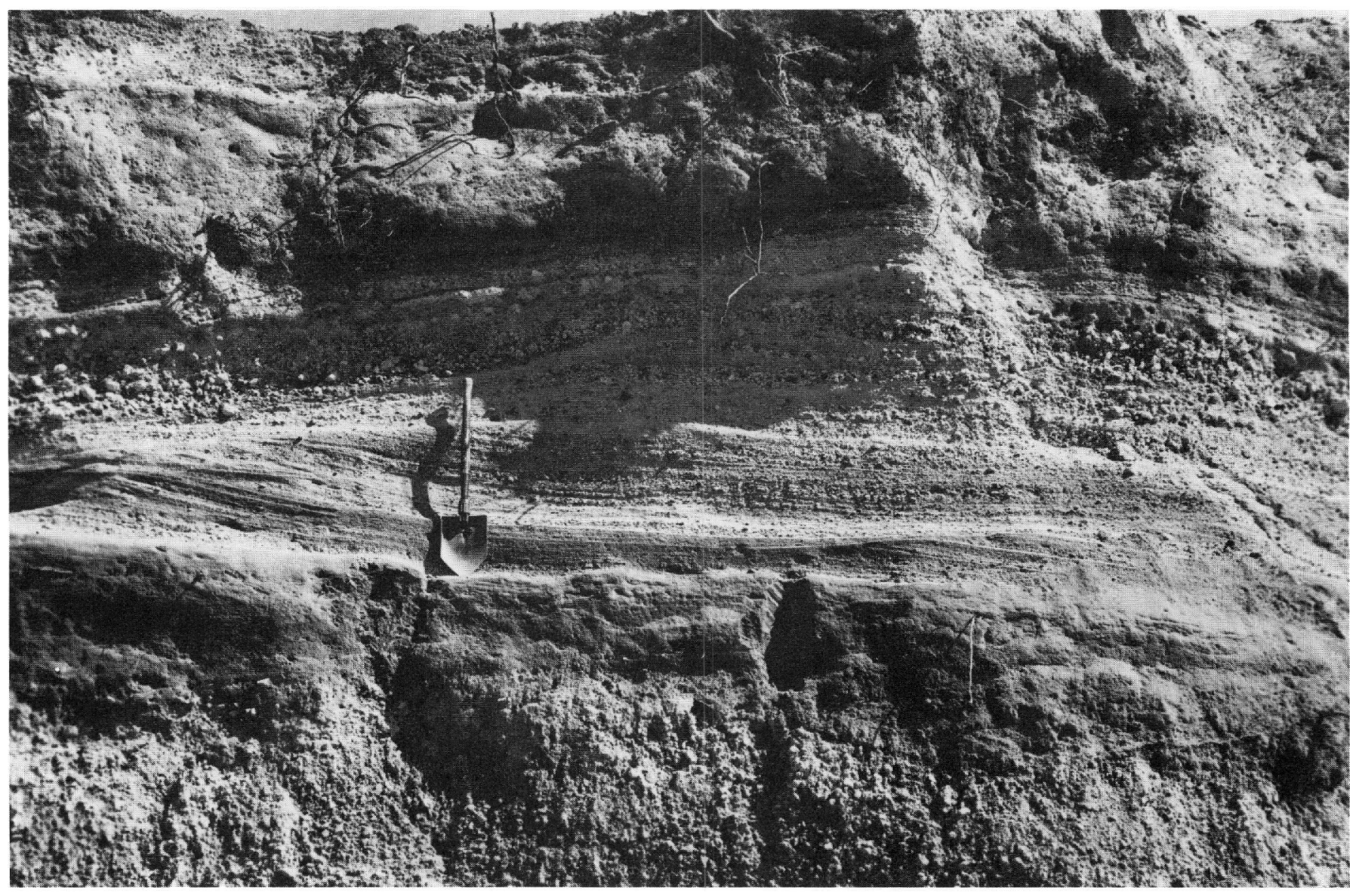

FIgURE 3.-Pyroclastic-surge deposits of Smith Creek age exposed in bank of Muddy River near Forest Road 83. 
on the slopes of a volcano, or on adjacent surfaces as a consequence of volcanic activity. The term is also commonly used to refer to the resulting deposit. Lahars that contain at least 50 percent material of sand size and smaller are mudflows; those with a lower content of fine material are debris flows (Varnes, 1958; Crandell, 1971, p. 3-4).

Lahars form deposits that generally are unsorted or poorly sorted and that have a range in grain size from clay to boulders several meters in diameter. Many lahars show a vertical textural gradation with the largest fragments concentrated in the lower half or two thirds of the deposit (Crandell, 1971, p. 6-7). Some lahars have a basal zone as much as several tens of centimeters thick in which pebble- to boulder-sized clasts are rare or absent (Schminke, 1967). This basal zone of fine material has led some workers to characterize mudflows as being reversely graded, despite a normal textural gradation in the upper part of most mudflows. The way in which the basal zone of fine material develops is not yet fully understood (Fisher, 1971, p. 925, and references cited therein).

Lahars and pyroclastic-flow deposits at Mount St. Helens resemble each other in many respects, such as constituent rock types, range in size distribution, shapes of clasts, texture and nature of the matrix, and range in compaction, although some other criteria are useful in distinguishing the two kinds of deposits (table 2). The distinction between coarse lithic deposits of pyroclastic flows and lahars is complicated by the fact that some lahars carry hot rock fragments; evidence of heat is thus not by itself proof of a pyroclastic-flow origin. Origin as a lahar is probable if wood in a deposit is not charred or if it is charred only where it is adjacent to a large rock fragment. This relation was observed in a deposit thought to have been formed by a hot lahar of Kalama age in the North Fork Toutle River valley that was exposed before 1980 in a streambank near the site of Spirit Lake Lodge (p. 79; Mullineaux and Crandell, 1962). Although few of the criteria shown in table 2 are unequivocal proof of the origin of a specific deposit, in combination they help distinguish some lahars from pyroclastic-flow deposits. Ways in which these deposits can be distinguished from coarse unsorted deposits of some other origins are discussed by Crandell (1971, p. 4-6) and are tabulated by Crandell and Mullineaux (1975).

Lahars, like debris flows and mudflows of nonvolcanic origin, are characterized by laminar flow and plug flow rather than by the turbulent flow that prevails in running water (Johnson, 1965, 1970; Fisher, 1971; Rodine and Johnson, 1976). Laminar flow is attributed to a high concentration of suspended solids, especially of finegrained material. These factors also are responsible for the high bulk density and internal strength that permit such flows to move large clasts long distances on low slopes (Rodine and Johnson, 1976).

A wide range in velocities has been reported for lahars. The fastest occur on the steep slopes of volcanoes, where movement may be in the nature of a debris avalanche, like the one of nonvolcanic origin from Nevada Huascaran in Peru in 1970. That avalanche descended 3,500 $\mathrm{m}$ in the upper $9 \mathrm{~km}$ of its course, where its average velocity was between 270 and $360 \mathrm{~km} / \mathrm{h}$ (Plafker and Ericksen, 1978, p. 301). The debris avalanche, perhaps in part airborne, graded downslope into a mudflow that moved more than $50 \mathrm{~km}$ downvalley at an average speed of $25 \mathrm{~km} / \mathrm{h}$ (Browning, 1973, p. 1340) or $35 \mathrm{~km} / \mathrm{h}$ (Plafker and others, 1971, p. 559). The collapse of a flank of Tokachidake volcano in Japan in 1926, triggered by an eruption, evidently caused an avalanche of rock debris (described as a mudflow) that reached a speed of $180 \mathrm{~km} / \mathrm{h}$ (Murai, 1963). A lahar that resulted from the avalanche reached a point $24 \mathrm{~km}$ downvalley from the volcano 25 minutes after the eruption, an average velocity of about $58 \mathrm{~km} / \mathrm{h}$ (Tada and Tsuya, 1927). Iida (1938, p. 681) reported a lahar at Mount Bandai in Japan in 1938 that had a speed of $90 \mathrm{~km} / \mathrm{h}$. This lahar, which traveled $3 \mathrm{~km}$, was caused by the saturation of volcanic ash by water from melting snow.

Speeds of considerably less than $90 \mathrm{~km} / \mathrm{h}$ are more commonly reported. Lahars that were caused by an eruption of Kelut volcano in Java in 1919 moved from the crater to a village $16 \mathrm{~km}$ downstream in 15 minutes, an average speed of $64 \mathrm{~km} / \mathrm{h}$ (Scrivenor, 1929). An eruption of Cotopaxi volcano in Ecuador in 1877 resulted in pyroclastic flows that moved downslope across snow and ice and created a lahar (Wolf, 1878; Miller and others, 1978) that is estimated to have had an average speed of $27 \mathrm{~km} / \mathrm{h}$ over a distance of $300 \mathrm{~km}$ (Macdonald, 1975). Debris flows that indirectly resulted from ash eruptions of Irazú volcano in Costa Rica in $1963 \mathrm{had}$ velocities of as much as $35 \mathrm{~km} / \mathrm{h}$ (Waldron, 1967). Average velocities of lahars generated by the May 18, 1980 , eruption of Mount St. Helens were generally less than $25 \mathrm{~km} / \mathrm{h}$ over distances of several tens of kilometers (Cummans, 1981).

The large length-to-height ratio of some lahars illustrates their extraordinary mobility. Lahars of Pine Creek age in the Kalama River valley descended from an assumed altitude of $2,000 \mathrm{~m}$ to about $30 \mathrm{~m}$ in a distance of about $53 \mathrm{~km}$; the resulting $\mathrm{L}: \mathrm{H}$ ratio is $29: 1$. Lahars of the same age in the North Fork Toutle River valley, which reached downstream to the Cowlitz River valley, descended from an assumed altitude of $2,000 \mathrm{~m}$ to about $20 \mathrm{~m}$ in a distance of $65 \mathrm{~km}$, resulting in a $\mathrm{L}: \mathrm{H}$ ratio of $35: 1$. 
TABLE 2.-Typical features of pyroclastic-flow deposits and lahars at Mount St. Helens

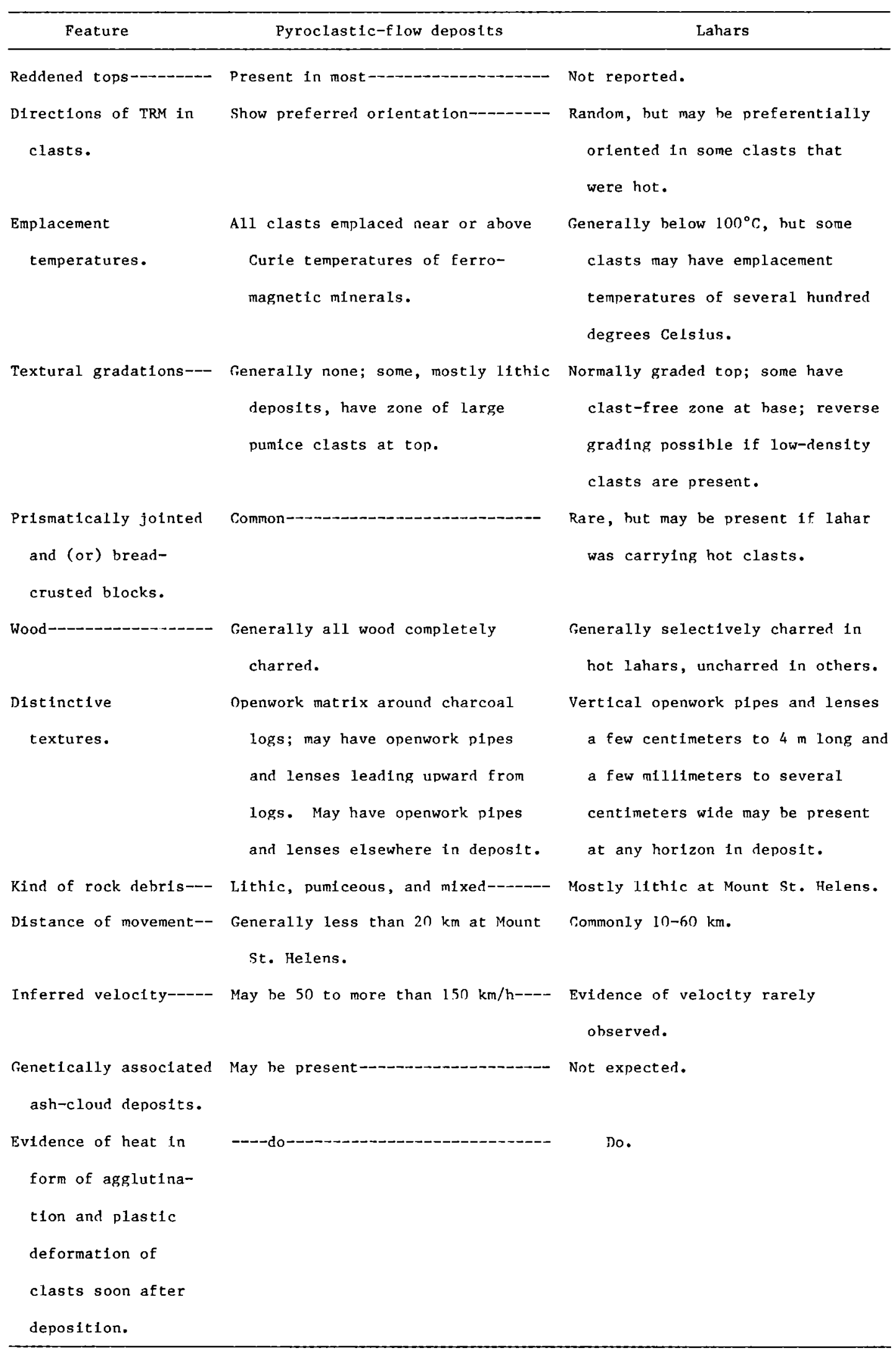


Lahars often result from eruptions and can also occur soon after or long after eruptions if the necessary conditions for their formation are met. These conditions are a source of fragmental material, adequate water to mobilize the debris, and a slope. Eruptions can produce lahars in many ways, including the following:

- eruption through and ejection of a crater lake,

- collapse of a crater wall enclosing a lake (also can occur during dormant periods),

- movement of a lava flow onto ice and snow,

- movement of a pyroclastic flow across ice and snow,

- sudden release of water impounded by a dam formed by a pyroclastic flow or debris avalanche, - avalanche of saturated rock debris,

- torrential rains falling on loose debris.

Lahars that flowed down the North Fork Toutle River valley on May 18, 1980, mainly resulted from the dewatering of the deposit of an enormous debrisavalanche that had moved some $20 \mathrm{~km}$ down the valley floor before coming to rest. Water running across the surface of the incoherent deposit rapidly cut into it and formed lahars that reached at least $120 \mathrm{~km}$ farther downstream (Janda and others, 1981).

Many of the prehistoric lahars at Mount St. Helens probably originated when pyroclastic flows crossed snow-covered areas. This mechanism of formation satisfies two of the requirements for lahars: a large volume of loose rock debris and water to mobilize it.

Lahars also can be formed when water stored within a glacier on a volcano is suddenly released. Such a "glacier-outburst flood" may result from meteorological conditions, release of temporarily blocked subglacial drainage, or from rapid melting of ice due to a steam vent or other source of heat.

\section{TEPHRA}

The term tephra is used in this report only for fragmental material which was erupted into the air at the volcano and which then fell on a ballistic trajectory or was transported laterally by wind before falling to the ground. (See Crandell and Mullineaux, 1973, p. 5-6.) The deposits of pyroclastic flows, pyroclastic surges, and associated ash clouds are excluded, even though these deposits fit one definition of tephra.

Tephra deposits at Mount St. Helens are divided into layers and groups of layers called sets (table 3). Each set consists of layers that contain similar suites of ironmagnesium silicate phenocrysts. The characteristics of the tephra sets at Mount St. Helens have been briefly described previously (Mullineaux and others, 1972, 1975, 1978; Crandell and Mullineaux, 1973; Mullineaux, 1986) and will be discussed in detail by D. R. Mullineaux in other reports.

\section{METHODS USED TO DATE DEPOSITS}

The ages of pyroclastic-flow deposits and lahars were determined mainly by radiocarbon age determinations on organic matter and by stratigraphic relations to other dated deposits such as tephra layers. Growth-ring counts of trees were used in a few places to limit the ages of the underlying deposits.

Radiocarbon dates are by far the most useful indicators of age because they pertain directly to the deposit from which the sample is obtained. Pieces of charcoal ranging from tiny fragments to logs $50 \mathrm{~cm}$ in diameter and $10 \mathrm{~m}$ long are abundant in the deposits of many pyroclastic flows, and partly charred or uncharred wood can frequently be found in lahars. However, there are limits on the accuracy of young radiocarbon dates. First, the ranges of uncertainty that were originally published for many of our radiocarbon dates typically are more than 50 percent of the reported age for samples less than 500 years old. This range of uncertainty can be decreased by reporting one standard deviation, a generally accepted practice that is used in this report, but the accuracy of the radiocarbon date itself is not thereby increased.

Second, dates on organic matter may not accurately reflect calendar years because of past variations in atmospheric radiocarbon that are revealed by radiocarbon dates on tree rings of known ages (Suess, 1970; Stuiver, 1978). These variations may not be significant in samples thousands of years old, because the difference in radiocarbon and calendar ages is only a small proportion of the radiocarbon date. But in young samples the discrepancy between the two kinds of dates may be more significant. Furthermore, some samples of a specified radiocarbon age can have two or three possible calendar ages. For instance, a sample with a radiocarbon age of about 610 years could date from 570 , 600 , or 640 years ago (Stuiver and Pearson, 1986).

A third complication is the range in error that can be introduced by sampling a log from a large tree that may have grown for several hundred years. A wood fragment from the outside of the log will yield a younger radiocarbon age than one from the core and will more closely date the event that killed the tree. This factor may have been contributed to different dates reported from charcoal samples we have obtained from the same deposit.

Ages of deposits only a few hundred years old thus cannot reliably be based on radiocarbon dates alone, but must also depend on stratigraphic relations and other dating criteria. In some places, the ages of deposits formed within the last few hundred years can be approximated or limited by determining the ages of trees growing on the deposits. Tree ages can be measured by coring trunks with an increment borer or by examining 
the stumps of recently cut trees and counting the annual growth rings. This dating method has limited accuracy. First, an interval of unknown duration elapsed between the time the deposit was formed and when the first seedling took root and survived. Second, it is unlikely that one can identify in a forest the first tree that took root and survived on a newly formed deposit. Third, to determine the oldest possible limiting date, it is necessary to cut a tree or bore into it so as to reach the ring formed during the first year of growth; this is seldom possible. These factors can add up to a significant difference between the time a deposit was formed and its apparent age as determined from tree rings.

One of the most useful methods for limiting the ages of pyroclastic-flow deposits and lahars and other eruptive products is to determine their stratigraphic relations to dated tephra layers. For example, a large, undated complex of lava flows on the southeast flank of the volcano is younger than tephra set $W$ because that tephra is not present on the flows even though they are within the fallout area of the tephra. Therefore, the lava flows must have been erupted since about A.D. 1480 , which evidently is the time when layer $W n$, the oldest part of set W, was formed (p. 69; Yamaguchi, 1982, 1983). The usefulness of tephra in bracketing the ages of other deposits is limited to the areas in which the tephra occurs. Because of prevailing westerly winds, most tephra erupted at Mount St. Helens was carried eastward; few such deposits occur west of the volcano. The usefulness of tephra in dating also depends on the distinction of one layer from another and on a knowledge of the ages of various layers. These details have been studied at Mount St. Helens by D. R. Mullineaux (Mullineaux and others, 1972, 1975, 1978; Crandell and Mullineaux, 1973; Mullineaux and Crandell, 1981).

The diameters of certain lichen species that have slow rates of growth have been used in many parts of the world to determine the ages of deposits on which they are found. In the Cascade Range about $120 \mathrm{~km}$ northeast of Seattle, Miller (1969) found that on moraines of various ages the ranges in maximum diameters (in millimeters) of Rhizocarpon sp. (cf. tinei) and Lecanora Aspicilia (cf. cinera) were as follows:

\begin{tabular}{|c|c|c|}
\hline $\begin{array}{l}\text { Moraines (ages } \\
\text { determined by } \\
\text { tree rings) }\end{array}$ & Rhizocarpon & Lecanora \\
\hline Early 20th century & $20-30$ & $15-50$ \\
\hline Late 19 th century & $10-40$ & $20-70$ \\
\hline Mid-19th century . & $40-65$ & $50-150$ \\
\hline 17th/18th centuries & $60-90$ & $70-90$ \\
\hline 16th/17th centuries & $40-100$ & $50-150$ \\
\hline 16th century $\ldots$. & $50-75$ & $100-200$ \\
\hline 15th/16th centuries & $70-100$ & $100-170$ \\
\hline 13th century .... & $80-200$ & $70-170$ \\
\hline
\end{tabular}

Miller used maximum diameters of lichens only in the relative dating of adjacent moraines. Nevertheless, such a broad range in maximum diameters, even in a relatively restricted area, demonstrates the limited usefulness of this dating method for determining the age of a specific deposit. At Mount St. Helens, two moraines that probably were formed near the end of the 19th century, as determined by tree rings, bear Rhizocarpon sp. lichens with maximum diameters of 25 and $30 \mathrm{~mm}$, which are consistent with Miller's data. However, lava flows that are thought to have been erupted in the 16th or 17th century bear Rhizocarpon sp. lichens that have maximum diameters ranging from 137 to $168 \mathrm{~mm}$; these lichens are considerably larger than those found on moraines of roughly the same age that were studied by Miller.

A comprehensive investigation of lichens on deposits and lava flows of various ages was not undertaken at Mount St. Helens because initial studies suggested that the construction of a reliable growth-rate curve from lichens growing on dated surfaces would be difficult, if not impossible. These studies also suggested that rock types influence not only the establishment of lichens but also their subsequent rate of growth. Rhizocarpon sp. lichens seem to colonize surfaces of dacite blocks less extensively than those of andesite, and then they grow more slowly. For example, blocks of dacite from the summit dome, which were deposited by pyroclastic flows and lahars in the late 16th or early 17 th century, bear lichens that have diameters of 50-70 $\mathrm{mm}$, whereas some andesite lava flows less than a century older and at similar altitudes bear lichens with diameters as large as 168 $\mathrm{mm}$.

Lichen sizes mentioned in this report were determined on Rhizocarpon sp. and are described for the record rather than as evidence for either relative or absolute age of the deposits on which they are found.

Many deposits can be dated only by their age relation to other units whose age has been determined between either wide or narrow limits. The ages of some lahars, for example, are limited by their stratigraphic position above deposits of the last major glaciation of the region; thus, they are younger than about 18,000 years.

\section{SUMMARY OF THE ERUPTIVE HISTORY OF MOUNT ST. HELENS}

The history of Mount St. Helens that can be inferred from the products of volcanism comprises repeated eruptions of variable volume, intensity, and duration. Most eruptions were separated by dormant intervals inferred principally from an absence of volcanic products of certain ages. Eruptions documented by the stratigraphic 
record at Mount St. Helens were initially grouped into nine eruptive periods (Crandell and others, 1981; Mullineaux and Crandell, 1981) on the basis of the mineralogy of eruptive products or intervening dormant intervals, or both. In that classification, eruptive periods and dormant intervals before 4,000 radiocarbon years ago had durations of thousands of years, whereas younger ones had durations of centuries. This disparity was an artifact of the way in which eruptive periods were defined and also reflected the greater amount of stratigraphic data available for younger periods than for the older ones. Stratigraphic evidence and radiocarbon dates suggest, however, that each of the three older eruptive periods included times of activity and dormant intervals of lengths similar to those of the last 4,000 years; thus, the frequency and duration of activity did not differ significantly before and after 4,000 years ago. Consequently, in this report, the eruptive history of the volcano is divided into four extended stages of intermittent activity, each lasting two thousand years or longer. The volcano is now in such a stage that began about 4,000 radiocarbon years ago. The long eruptive stages have been separated by dormant intervals of a few thousand to many thousands of years during which there is little or no recognizable evidence of eruptive activity in the stratigraphic record. During each eruptive stage, eruptive periods with lengths on the order of decades or centuries alternated with dormant intervals of similar duration. Eruptive periods of the current eruptive stage are given geographic names in this report; although similar periods are recognized during older stages, they are not yet named.

Some eruptive periods could also be subdivided into eruptive episodes or phases based on stratigraphic successions of different rock types or on the occurrence of dormant intervals during the period. For example, the Kalama eruptive period of 500-350 years ago could be subdivided into early dacite, middle andesite, and late dacite episodes; and the Smith Creek eruptive period of $4,000-3,300$ years ago could be split into two or three eruptive episodes by evidence for one or two dormant intervals. Although the stratigraphic evidence for some subdivisions is described in this report, the subdivisions are not given geographic names.

The history of the volcano as known in 1983 is summarized in table 3 , which lists the general nature of eruptive activity and tephra sets produced during each eruptive stage and period.

The current eruptive period began at Mount St. Helens on March 27, 1980. During the following 5 years the most conspicuous and widespread products of volcanism, and those most likely to be preserved, included (1) air-fall tephra and deposits of pyroclastic flows, lahars, a lateral blast, and a debris avalanche, all of which were formed on May 18, 1980, and (2) a dome whose growth began in June 1980 and continued intermittently through 1985 . Earlier eruptive periods probably also included similarly brief, violent episodes of activity which formed most of the eruptive products preserved in the geologic record and which were separated by long intervals of dormancy.

Unconsolidated deposits of various ages at Mount St. Helens are grouped in the following discussion according to the eruptive stages or periods and glaciations during which they were formed, and some of the discussion is further subdivided according to the side of the volcano or the valley where the deposits are exposed. Specific localities described in the text are identified on the topographic map of the Mount St. Helens area (pl. 1 in pocket).

\section{DEPOSITS OF \\ PRE-MOUNT ST. HELENS GLACIATIONS}

Deposits that record the extent of glacier ice during various glaciations of the Mount St. Helens region have not been studied in detail, although glacial deposits were noted at many scattered localities. These deposits show that the area was mostly or entirely covered by glaciers at least once prior to the last major glaciation (Fraser glaciation, p. 24). These pre-Fraser glaciers predated the appearance of Mount St. Helens.

Glacial deposits older than the volcano crop out at widely scattered localities east, south, and west of Mount St. Helens, and they underlie a broad area more than $30 \mathrm{~km}$ southwest of the volcano between the valleys of the Lewis River and the East Fork Lewis River. East of Mount St. Helens, till of pre-Fraser age is well exposed along a logging road on the north wall of Ape Canyon (locality 13) at an altitude of about $610 \mathrm{~m}$ (measured section 3, p. 33). The till is more than $2 \mathrm{~m}$ thick (fig. 4) and contains faceted and striated stones in a very compact dark-gray matrix of sand and silt. No rocks derived from Mount St. Helens were recognized in the till. The till directly underlies tephra set $\mathrm{C}$, which is believed to be at least 36,000 years old (p. 20) and is the oldest tephra erupted at the site of Mount St. Helens (Mullineaux and others, 1978). A soil at the top of the till, which is represented by a brown $(10 Y R \quad 4 / 3)^{3}$ oxidized zone $75-100 \mathrm{~cm}$ thick, indicates that the till was exposed at the ground surface for a long time before the tephra was deposited. The thickness of the buried oxidized zone is similar to that developed elsewhere in the Cascade Range on till of Fraser age (Crandell and Miller, 1974, p. 29), which has been exposed to weathering processes for about 15,000 years. A similar interval may therefore have elapsed between the eruptions of Mount St. Helens that

${ }^{3}$ Color notations are those of the Munsell system (Munsell Color Company, 1954). 
TABLE 3.-Eruptive history of Mount St. Helens

[Tephra units from Mullineaux and Crandell (1981)]

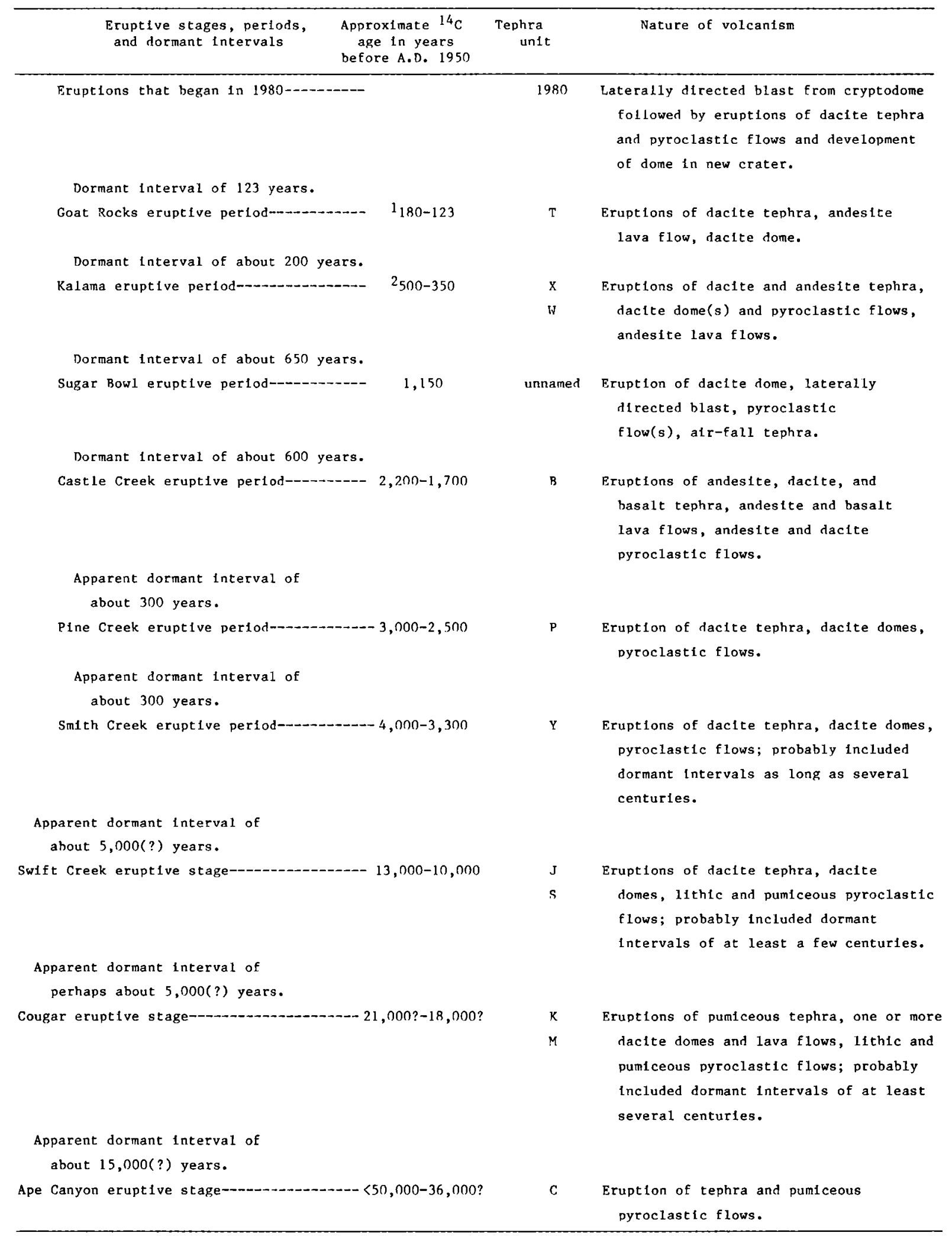

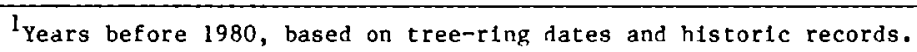

${ }^{2}$ Years before 1980 , based on tree-ring dates and ${ }^{14} \mathrm{C}$ dates. 
produced tephra set $\mathrm{C}$ and the preceding glaciation. The till exposed at Ape Canyon is probably correlative with the Hayden Creek Drift of the Mount Rainier region (Crandell and Miller, 1974), which was formed during the next-to-last major glaciation of that area. Crandell and Miller correlated the Hayden Creek glaciation with world-wide climate and ice-volume variations, which have been inferred from $\mathrm{O}^{18} / \mathrm{O}^{16}$ ratios in deepsea sediments, and suggested that the Hayden Creek glaciation occurred between 80,000 and 40,000 years ago. This is the interval referred to as oxygen-isotope stage 4, which is now thought to have extended from about 73,000 to 61,000 years ago (Hays and others, 1976).

Till also crops out on the west valley wall of Pine Creek at an altitude of about $580 \mathrm{~m}$ (locality 34), where it directly underlies tephra layers of set $\mathrm{C}$. The unoxidized color of the till is dark grayish brown (10YR 4/2), but the upper $60 \mathrm{~cm}$ is oxidized strong brown $(2.5 Y R$ 5/6). The till contains no rocks known to have been derived from Mount St. Helens. A similar till, associated with gravel, is exposed along an abandoned logging road (locality 36) beneath tephra of set $C$, at an altitude of about $518 \mathrm{~m}$.

A pre-Fraser till overlies bedrock at two localities along Forest Road 90 on the north side of the Lewis River valley. One outcrop is near the northeast end of the bridge over Swift Creek (locality 42), and the other is on the west side of the Camp Creek valley (locality 38). Both outcrops are at an altitude of about $335 \mathrm{~m}$ and are beyond the farthest point reached by a glacier of Fraser age in the Lewis River valley (p. 26).

Till that is overlain by tephra of set $C$ crops out in a roadcut on the north side of the Kalama River valley at locality 64 , about $15 \mathrm{~km}$ downvalley from the west base of Mount St. Helens. This exposure is at an altitude of about $460 \mathrm{~m}$ on a spur that separates the Kalama and North Fork Kalama River valleys. The till is oxidized to a depth of about $50 \mathrm{~cm}$ and does not contain any rock debris from Mount St. Helens. Glacial drift was noted but not examined in detail at several localities farther down the Kalama River valley.

Glacial deposits are exposed at many localities in the area between the Lewis River and East Fork Lewis River

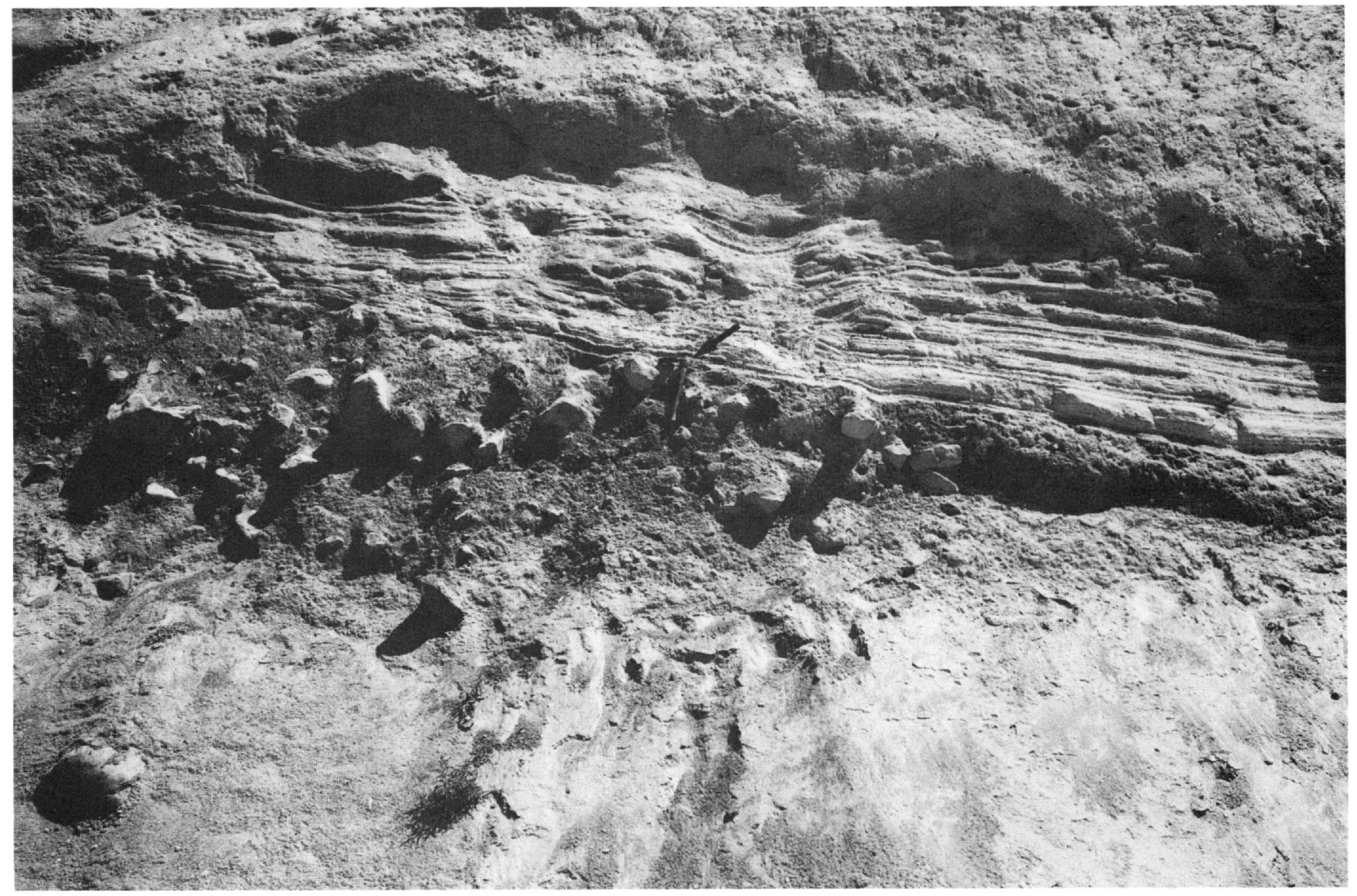

FIGURE 4.-Beds of lithic ash of tephra set C overlying bouldery till of Hayden Creek(?) age in roadcut on north side of Ape Canyon. Pick handle is about $45 \mathrm{~cm}$ long. 
southwest of Yale Dam. Mundorff (1984) concluded that these deposits represent a single glaciation. He described the till in this area as being oxidized to a depth of 1.5-2 $\mathrm{m}$ and containing stones which have weathering rinds with an average thickness of $1.63 \mathrm{~mm}$ and a range of 0.5 to $4 \mathrm{~mm}$. Mundorff suggested that stones with weathering rinds thicker than $2 \mathrm{~mm}$ had been picked up from underlying, more deeply weathered deposits and were then redeposited by the glacier. The origin of the Fargher Lake basin, which is a depression largely enclosed by glacial drift $6 \mathrm{~km}$ south-southeast of Merwin Dam, was attributed by Mundorff to block faulting.

I believe that at least two pre-Fraser glaciations are represented by the glacial drift south of the Lewis River valley. Till deposited by the younger glacier forms moraines 1-2 km west of the Fargher Lake basin, and the basin itself seems to have been formed by the blockage, by till, of pre-existing stream valleys. A representative outcrop of this till is in a roadcut in the SW1/4 SW1/4 sec. 23 , T. 5 N., R. 2 E., on the west slope of the Fargher Lake basin. Inspection of 30 cobbles of basalt taken from the upper $1.5 \mathrm{~m}$ of this till revealed weathering rinds which range in thickness from 1 to $4 \mathrm{~mm}$ and average $2.2 \mathrm{~mm}$. This till may be correlative with the Hayden Creek Drift in the Mount Rainier region, in which stones have similar weathering rind thicknesses (Crandell and Miller, 1974, p. 21-29). Crandell and Miller noted that the terminus of a glacier of Hayden Creek age reached an altitude of about $180 \mathrm{~m}$ in the Cowlitz River valley. The terminus of the Lewis River glacier of the same age may have reached an altitude of about $240 \mathrm{~m}$ west of the Fargher Lake basin.

Many roadcuts west and southwest of the Fargher Lake basin reveal a more extensively weathered till. A representative outcrop of this till is in a roadcut in the NW1/4NE1/4 sec. 9, T. 4 N., R. 2 E., $5.7 \mathrm{~km}$ southwest of the Fargher Lake basin. There, weathering rinds on 30 basalt cobbles in the upper $2 \mathrm{~m}$ of the till were found to range in thickness from 3 to $15 \mathrm{~mm}$ and average $6.2 \mathrm{~mm}$. This outcrop is at an altitude of about $140 \mathrm{~m}$, but the altitude of the glacier terminus is not known. This till seems to be more extensively weathered than that of Wingate Hill age in the Mount Rainier region and thus probably is older.

The absence in this till of stones having thin weathering rinds suggests that the stones with thick rinds were weathered in place and not in some older deposit from which they were subsequently picked up by a glacier and redeposited. Furthermore, the likelihood seems very low that the thick, soft clayey weathering rinds that characterize stones in this till would have survived glacier transport.

The distribution of the glacial deposits south of the Lewis River valley shows that at least two massive glaciers moved westward down that valley during preFraser time, both of which pre-dated the birth of the volcano.

An end moraine in the South Fork Toutle River valley on the east side of Whitten Creek (locality 73) is about $20 \mathrm{~km}$ downvalley from the base of Mount St. Helens. Till exposed at a roadcut through the moraine is not overlain by any other deposit and is oxidized to a depth of more than $1.8 \mathrm{~m}$, and stones in the upper part of the till have weathered rinds as much as $2 \mathrm{~mm}$ thick. It is not known whether this moraine represents the farthest extent of the South Fork glacier or is a recessional moraine. The extent of weathering in the till at Whitten Creek is similar to that on Hayden Creek Drift in the Mount Rainier region (Crandell and Miller, 1974).

A pre-Mount St. Helens valley glacier originating in the North Fork Toutle drainage basin extended between 30 and $35 \mathrm{~km}$ downvalley from the site of Spirit Lake. At a point about $3 \mathrm{~km}$ upvalley from Camp Baker, lateral moraines on both sides of the North Fork valley are as much as $330 \mathrm{~m}$ above the pre-1980 valley floor. On the south side of the valley, till in a pair of parallel lateral moraines (locality 79) (fig. 5) contains stones that have weathered rinds as much as $2 \mathbf{m m}$ thick. Rinds of similar thickness on stones in the weathering profile on till at Mount Rainier are typical of the Hayden Creek Drift (Crandell and Miller, 1974). Glacial deposits were not observed upslope from these two moraines.

\section{APE CANYON ERUPTIVE STAGE}

\section{DEPOSITS}

The time during which the earliest known eruptive products of Mount St. Helens were formed has been named the Ape Canyon eruptive stage. Products of Ape Canyon age near the volcano include air-fall tephra, pyroclastic-flow deposits, and a lahar. The flowage deposits are exposed at only a few places, but this probably is attributable to their removal elsewhere by erosion or to burial by younger deposits.

Explosive eruptions during the Ape Canyon eruptive stage produced tephra set $\mathrm{C}$, in which phenocrysts of hornblende and cummingtonite are abundant, and those of biotite are less common but ubiquitous (D. R. Mullineaux, written commun., 1984). The basal layer of set $\mathrm{C}$ consists chiefly of lithic ash and lapilli and is about $1 \mathrm{~m}$ thick at distances of $10-15 \mathrm{~km}$ east and southeast of the summit of the volcano. At many places this tephra directly overlies a soil developed on till of Hayden Creek(?) age. In the Pine Creek valley $13 \mathrm{~km}$ southeast of the volcano (locality 34), this lithic tephra is about $1.1 \mathrm{~m}$ thick and is oxidized yellowish brown 


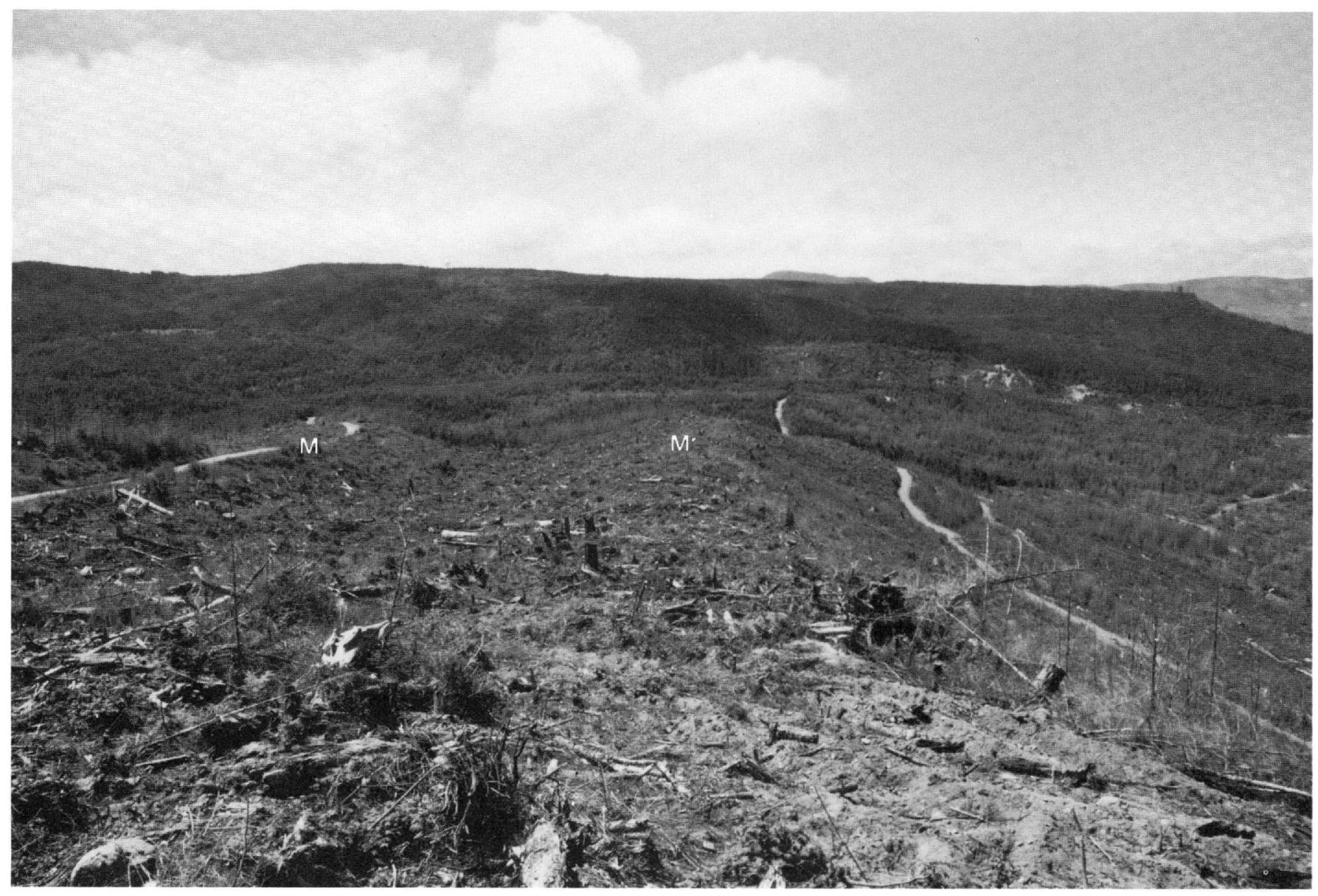

Figure 5.-View west along lateral moraines (M) of Hayden Creek(?) age on the south side of the North Fork Toutle River valley east of Deer Creek.

in the uppermost $20-25 \mathrm{~cm}$. As many as three zones of oxidation have been noted elsewhere within tephra of set C (D. R. Mullineaux, oral commun., 1979).

Zones of oxidation within tephra deposits of Ape Canyon age probably were formed by weathering processes during intervals of many hundreds of years before those deposits were covered by new layers of tephra. The geologic evidence suggests that tephra deposits of Ape Canyon age were formed over successive eruptive periods that together could have spanned several thousand years.

Pyroclastic-flow deposits of Ape Canyon age can be seen interbedded with tephra of set $\mathrm{C}$ along Forest Road 92 100-200 m south of Ape Canyon Creek (locality 16) (fig. 6). Phenocrysts in pumice ash and lapilli that make up the deposits are similar to those in tephra set $\mathrm{C}$. The oldest two deposits of this sequence are conformable and are each a few tens of meters thick; the presence of rock of Tertiary age exposed in a ditch beside the road about $30 \mathrm{~m}$ to the south suggests that the base of the lowest pyroclastic-flow deposit is not far below road level. That deposit consists of a compact unstratified mixture of rounded white pumice lapilli and angular lithic lapilli in a matrix of pumiceous and lithic ash. It is overlain by a few centimeters of horizontally bedded ash, above which is another pyroclastic-flow deposit lithologically similar to the lower one. These deposits are all unconformably overlain by north-sloping beds of pumiceous ash and lapilli about $30 \mathrm{~cm}$ thick (fig. 7). These beds contain a light-yellowish-brown zone of oxidation about $15 \mathrm{~cm}$ thick. The beds, and half a meter of colluvium that overlies them, evidently were deposited on the side of a valley cut into the older pyroclastic-flow deposits.

Banked against this succession of deposits is another pumiceous pyroclastic-flow deposit at least $20 \mathrm{~m}$ thick. It consists of pumice ( 70 percent) and lithic ( 30 percent) lapilli in an ash matrix; nearly all the clasts are less than $10 \mathrm{~cm}$ in diameter. A chemical analysis of a pumice clast from this deposit indicated a $\mathrm{SiO}_{2}$ content of 66.7 


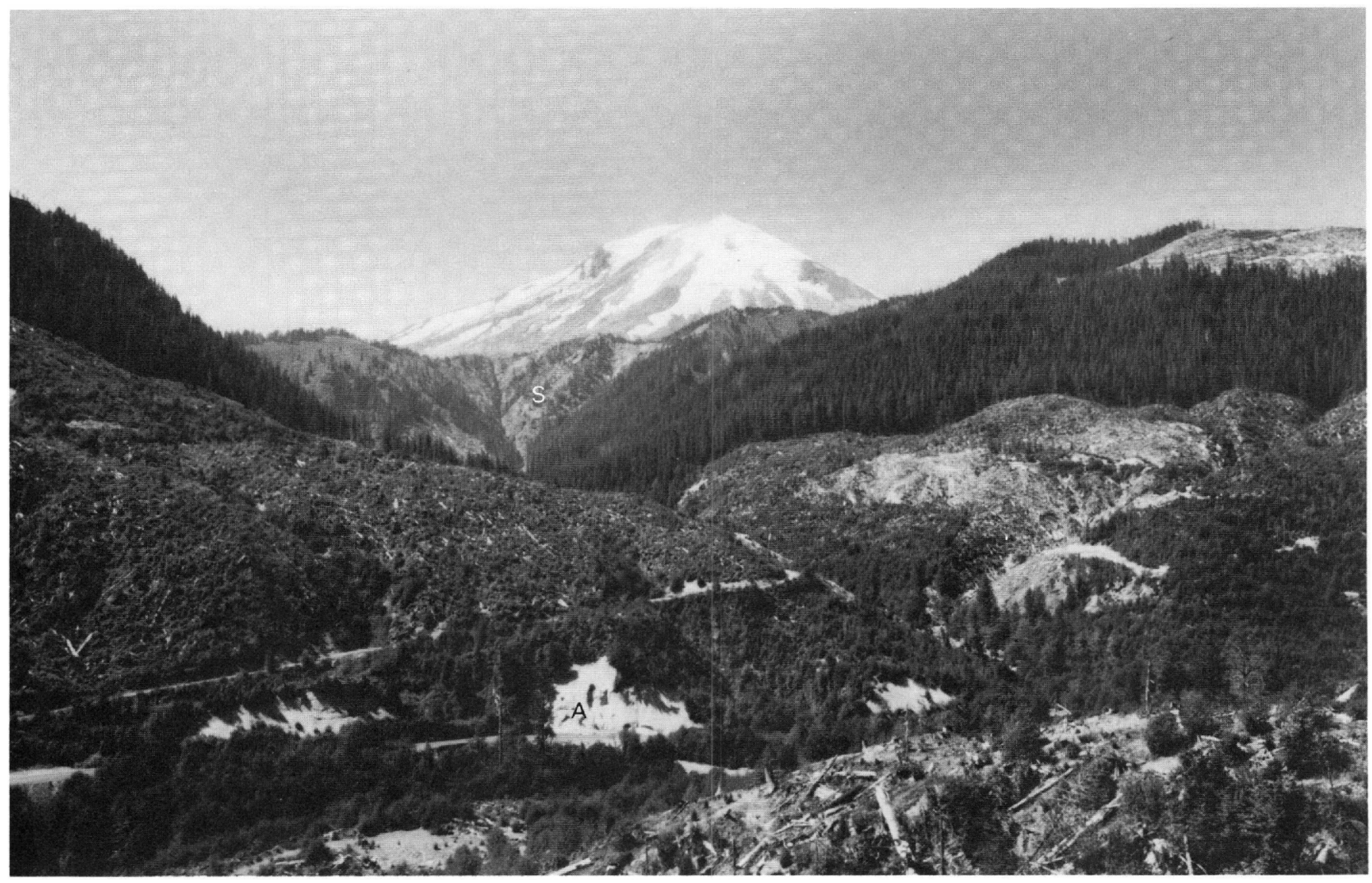

FiguRE 6.-View west across the Smith Creek valley toward Ape Canyon and Mount St. Helens. Large light-colored outcrop (A) in lower center is shown in detail in figure 8. Note scarp (S) at head of canyon that separates Ape Canyon from the base of the volcano. Photograph taken in 1978.

percent (sample 1, app. A). The deposit is overlain by $6 \mathrm{~m}$ of stratified pumiceous ash that contains two weakly oxidized zones, probably formed during periods of weathering between eruptions. The ash is overlain by a lenticular pumiceous pyroclastic-flow deposit as much as $1.5 \mathrm{~m}$ thick, followed by $4 \mathrm{~m}$ of stratified pumiceous ash.

A cut along Forest Road 92, just north of Ape Canyon Creek, exposes lithic tephra of Ape Canyon age resting on clayey dark-brown till of Hayden Creek(?) age. The tephra is unconformably overlain by two pumiceous pyroclastic-flow deposits similar to the older of those exposed along the road south of Ape Canyon Creek. Beneath the unconformity is a south-sloping surface cut into the lithic tephra, and a zone of oxidation about $45 \mathrm{~cm}$ thick in the tephra beneath the unconformity probably represents a weathering interval before the pyroclastic flows occurred.

A lahar of Ape Canyon age crops out in the north bank of the Lewis River about $2.5 \mathrm{~km}$ downstream from Swift Dam (locality 50). The deposit contains clasts of various rock types in a compact matrix of silty sand. Clasts of dense rock are as large as $1 \mathrm{~m}$ in maximum diameter and include fragments of gray dacite, some prismatically jointed, and pumice that contains cummingtonite, hornblende, and biotite and that resembles tephra of set $\mathrm{C}$. The deposit also contains abundant fragments of wood, some partly carbonized. According to Hyde $(1975$, p. 11), pumiceous wood-bearing deposits thought to be lahars were encountered in drill holes at the site of Swift Dam to a depth of about $49 \mathrm{~m}$ below the present river level. These lahars evidently originated during the explosive eruptions of Ape Canyon time.

After the eruption of May 18, 1980, three pumiceous pyroclastic-flow deposits of Ape Canyon age were exposed in the south valley wall of the Muddy River (locality 25). The deposits consist of ash and lapilli of hornblende-cummingtonite-biotite pumice and resemble those exposed near the mouth of Ape Canyon. From bottom to top, the exposed thicknesses of these three deposits are $1.8,1$, and $0.5 \mathrm{~m}$, respectively. They are unconformably overlain by a lithic pyroclastic-flow 


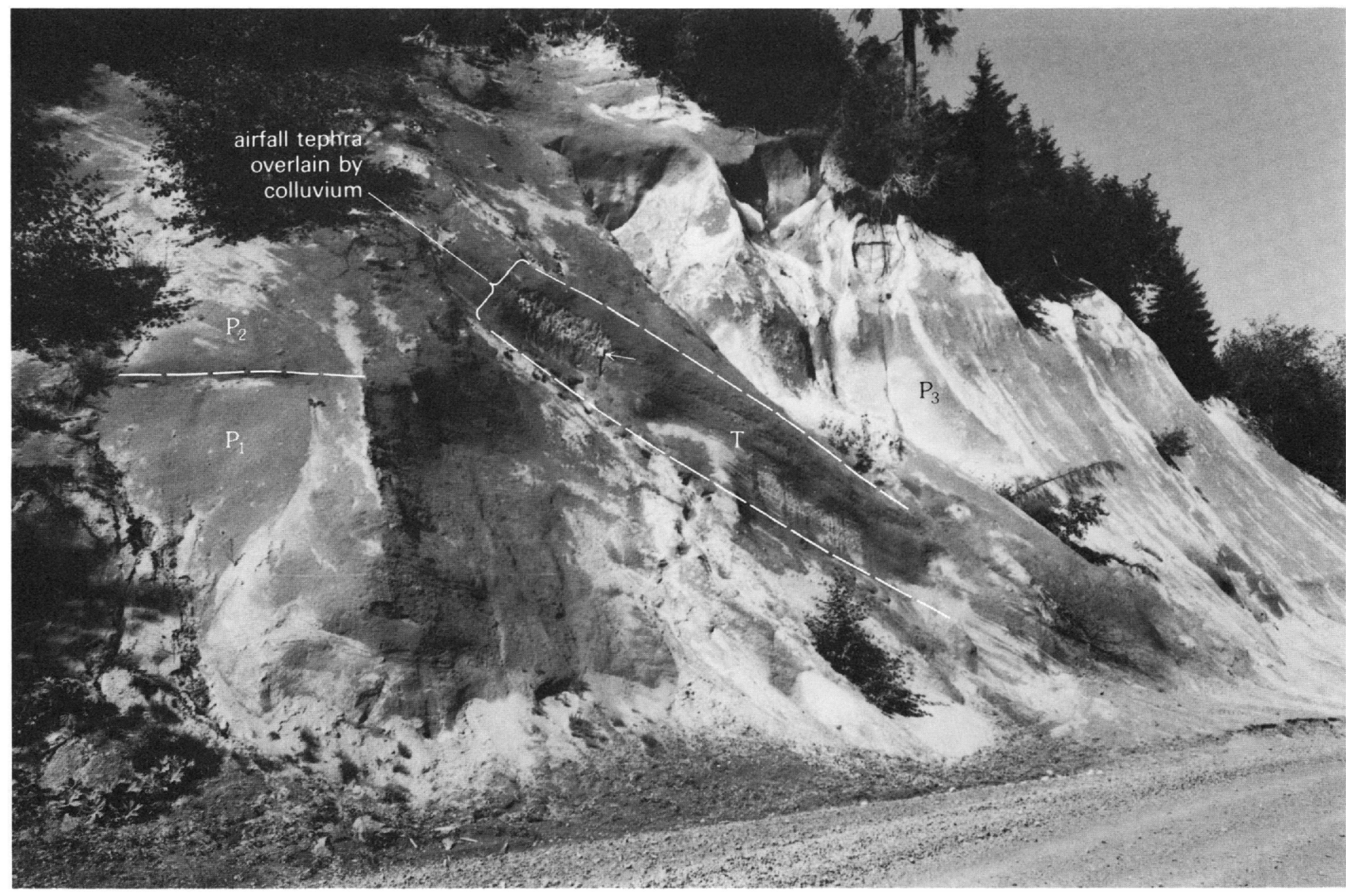

Figure 7.-Pumiceous pyroclastic-flow deposits $\left(\mathrm{P}_{1}, \mathrm{P}_{2}, \mathrm{P}_{3}\right)$ of Ape Canyon age interbedded with ash and lapilli and colluvium (T) in outcrop along Forest Road 92 south of mouth of Ape Canyon. (See fig. 6). Scale is indicated by shovel $70 \mathrm{~cm}$ long (arrow).

deposit of Swift Creek age that is younger than tephra set S. The pyroclastic-flow deposits of Ape Canyon age probably overlie till of Hayden Creek(?) age, which crops out a few hundred meters to the east and which overlies weathered bedrock of Tertiary age.

Sandy alluvium and lahars of Ape Canyon age that consist largely of biotite-bearing pumice are present in the South Toutle River valley about $40 \mathrm{~km}$ downstream from the volcano. A remnant of this valley fill is present on a rock knob in the center of the valley at the Weyerhaeuser Company's "East Area," 7 km eastsoutheast of the community of Toutle Lake. There, alluvium about $5.3 \mathrm{~m}$ thick overlies lenticular gray silt and clay as much as $60 \mathrm{~cm}$ thick and pebble, cobble, and boulder gravel about $2 \mathrm{~m}$ thick. The gravel is mostly oxidized yellowish red ( $5 Y R$ 5/8). Although it is heterolithologic, it contains no rocks derived from Mount St. Helens. The top of the pumiceous alluvium is about $15 \mathrm{~m}$ higher than the adjacent South Fork Toutle River. According to K. M. Scott (written commun., 1984), deposits of Ape Canyon age in the South Fork valley farther downstream include at least five lahars as well as alluvium, and similar deposits are present in the Toutle River valley about $7 \mathrm{~km}$ downstream from the confluence of the North and South Forks.

\section{NATURE AND AGE OF VOLGANISM}

The initial eruptions of the Ape Canyon eruptive stage produced lithic tephra. These were followed by eruptions of lithic and pumiceous tephra and pumiceous pyroclastic flows. Thus, the eruptions that marked the birth of Mount St. Helens were explosive as was much of the volcanism during the subsequent history of the volcano. The presence of prismatically jointed blocks of nonvesicular dacite in the lahar exposed in the bed of the Lewis River suggests, however, that one or more domes or lava flows were erupted at the volcanic center during Ape Canyon time.

The Toutle River valley evidently was aggraded by lahars and alluvium downstream to its confluence with 
the Cowlitz River during Ape Canyon time, and the Cowlitz River valley probably also was aggraded downstream to the Columbia River. The abundance of pumice in the valley-fill deposits indicates that the aggradation was caused by large amounts of newly erupted material being contributed to the drainage system during the initial explosive eruptions of Mount St. Helens.

Radiocarbon dates of $37,600 \pm 1,300(\mathrm{~W}-2661)$ and $36,000 \pm 2,500$ years (W-2976) have been obtained from tephra set $\mathrm{C}$. The older date was on charcoal taken from ash at the base of the set, and the younger date was from charcoal in a stratigraphically higher part of the set (D. R. Mullineaux, oral commun., 1979). A sample of wood from the lahar exposed in the bed of the Lewis River yielded a radiocarbon age of $36,000 \pm 2,100$ years (W-2653; Hyde, 1975, p. 6), a date consistent with those on the tephra. However, charcoal from a pyroclastic-flow deposit near the mouth of Ape Canyon had a radiocarbon age greater than 42,000 years (W-3259). This deposit is stratigraphically younger than part of tephra set C. Its age of more than 42,000 years suggests the possibility that the other dates on deposits of Ape Canyon age represent contaminated samples and thus are not valid. Yet, the close grouping of the three finite dates suggests that they are not due to contamination of old organic matter by younger material. On the basis of the data now available, I believe that the Ape Canyon eruptive stage began some time between 40,000 and 50,000 years ago and lasted until at least 36,000 years ago.

\section{GOUGAR ERUPTIVE STAGE}

\section{DEPOSITS}

The Cougar eruptive stage probably extended from a little more than 20,000 years ago to some time after about 18,000 years ago during the Fraser glaciation when glaciers in the Cascade Range, including the Mount St. Helens area, were at or near their maximum extents (Crandell, 1965, p. 346). Volcanic deposits of Cougar age underlie glacial drift near the volcano in areas reached by glaciers of Fraser age. Volcanic products of Cougar age include pyroclastic-flow deposits, lahars, tephra, at least one lava flow, and a deposit of a debris avalanche from the volcano. The stratigraphic sequence of Cougar deposits is summarized in table 4. Some of the deposits of Cougar age exposed in the valleys of the Lewis River and Swift Creek were described by Hyde (1975) as part of his Swift Creek volcanic assemblage.

Deposits of Cougar age can be distinguished from those of the early part of the following Swift Creek eruptive period by their radiocarbon age and stratigraphic relations to tephra sets. Pyroclastic-flow deposits of Cougar age generally contain hypersthene-hornblende dacite; those of Swift Creek age contain hornblendecummingtonite dacite. However, dacite that contains only hornblende as the iron-magnesium silicate phenocryst is found in deposits of both Cougar and Swift Creek age.

TABLE 4.- Inferred stratigraphic sequence of deposits formed during the Cougar eruptive stage

[Predominant iron-magnesium silicate phenocrysts in tephra are from Mullineaux and others (1978). Tephra set K may have been erupted at about the time Fraser glaciers were at their maximum extents; older deposits locally underlie till of Fraser age. Leaders (----) indicate no data available.]

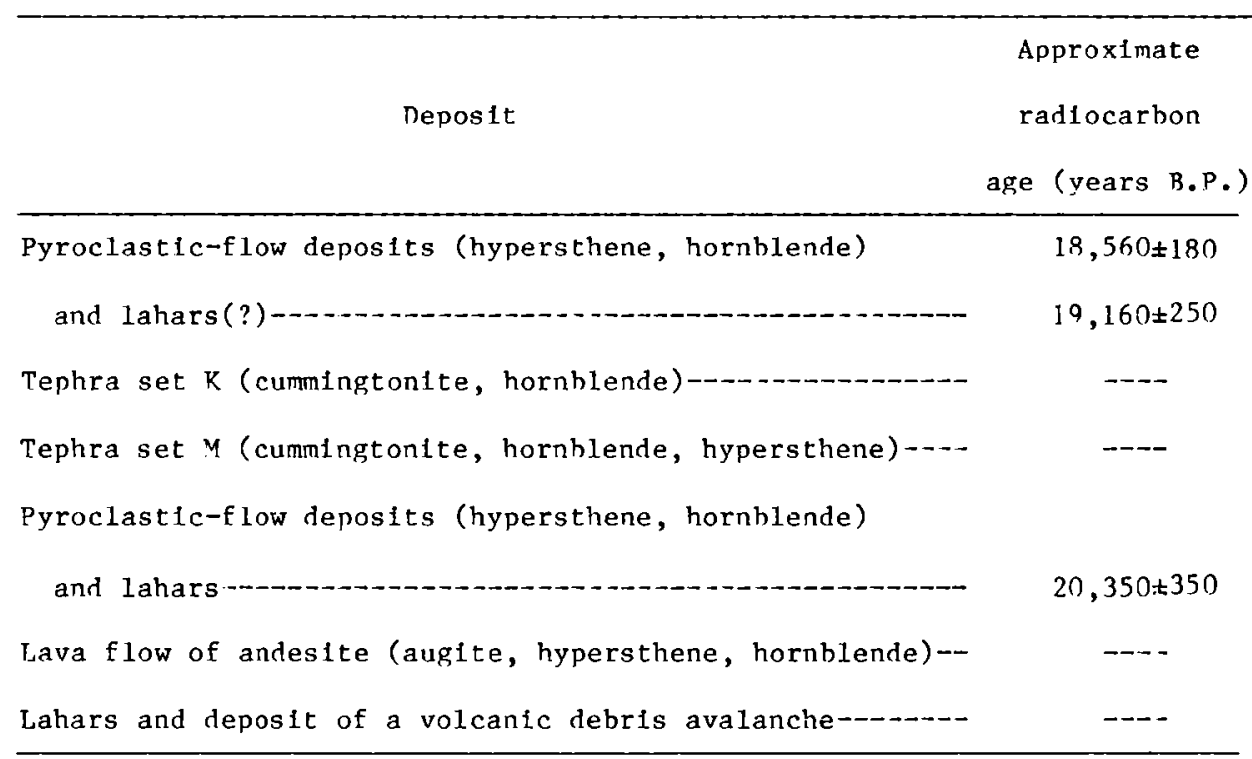


SOUTH AND SOUTHWEST SIDES OF THE VOLCANO

A sequence of lahars probably represents the oldest deposits of Cougar age. These are exposed in roadcuts on both sides of the Lewis River valley just west of Swift Dam and near McBride Lake. The lahar sequence exposed in cuts along Forest Road 90 on the north wall of the Lewis River valley (locality 45) is more than $23 \mathrm{~m}$ thick. At those roadcuts, the lahars contain hornblendehypersthene dacite and are overlain by a deposit about $20 \mathrm{~m}$ thick of angular dacite fragments in a compact silt and sand matrix. The dacite contains hornblende, biotite, and minor amounts of apatite. Most of the deposit is gray, but it includes masses many meters across of red dacite debris. Hyde (1973) reported that rock fragments he sampled had random directions of thermoremanent magnetism (TRM), as did samples taken from two horizons in the deposit by K. S. Kellogg (written commun., 1975); thus, the deposit probably was cold when it was emplaced. It probably was formed by a debris avalanche from the volcano (Mullineaux and Crandell, 1981; Newhall, 1982). The presence in the deposit of clasts containing biotite suggests that it was derived from rocks of Ape Canyon age.

The deposit exposed in a cut along Forest Road 90 is unconformably overlain by a heterolithologic lahar 2-3 $\mathrm{m}$ thick, above which is a pumiceous pyroclasticflow deposit that is about 20,350 years old. The lahar contains clasts of hornblende-hypersthene dacite, some prismatically jointed, and clasts of dacite like those in the underlying debris-avalanche deposit.

A deposit probably correlative with the debris avalanche crops out in a cut along Forest Road 81 near McBride Lake (locality 55). It is more than $8 \mathrm{~m}$ thick and consists of angular dacite fragments as much as $15 \mathrm{~cm}$ in maximum diameter in a compact silt and sand matrix. The dacite clasts are mineralogically similar to those in the debris avalanche exposed near Swift Dam. According to Hyde (1973), rock fragments in the deposit near McBride Lake had random directions of TRM. The base of the deposit is not exposed in the roadcut, but lahars in a gully a short distance to the southeast contain hornblende-hypersthene dacite. These lahars probably are stratigraphically below the debris-avalanche deposit. The debris-avalanche deposit that crops out in the roadcut is overlain by two pyroclastic-flow deposits of Cougar age. The lower of these is as much as $3 \mathrm{~m}$ thick and consists of hornblende-bearing nonvesicular dacite. It is overlain by a pyroclastic-flow deposit of pumiceous hypersthene-hornblende dacite about $70 \mathrm{~cm}$ thick. These two pyroclastic flows are interbedded with fluvial deposits and are overlain by till of Fraser age.

One of the largest lava flows at the volcano, and one of the few lava flows recognized that were erupted prior to 2,500 years ago, extends about $6 \mathrm{~km}$ down the south flank of the volcano from an altitude of $1,825 \mathrm{~m}$ to about $700 \mathrm{~m}$. The flow consists of andesite in which phenocrysts of iron-magnesium silicate minerals include augite, hypersthene, and hornblende; the $\mathrm{SiO}_{2}$ content of the andesite is 61 percent (C. A. Hopson, written commun., 1971). The flow evidently moved down and filled an ancestral valley of Swift Creek, and south-flowing drainage subsequently was established along both its margins. The flow is as much as $180 \mathrm{~m}$ thick and about $1.8 \mathrm{~km}$ wide, and covers an area of at least $6 \mathrm{~km}^{2}$. If an average thickness of $90 \mathrm{~m}$ is assumed, the volume of the flow probably is at least $0.5 \mathrm{~km}^{3}$.

Exposures along Forest Road 83 in the Swift Creek valley (locality 44) show the lava flow to be overlain by a pumiceous pyroclastic-flow deposit of Cougar age. Pumice blocks in the pyroclastic-flow deposit contain hypersthene and hornblende and resemble those in similar deposits on the south side of the Lewis River valley which are described below. The lava flow and the overlying deposit are overlain in the roadcut outcrops by pyroclastic-flow deposits and lahars of Swift Creek age.

If this large lava flow was erupted at a central crater, its distribution on the south side of the volcano may have resulted from earlier destruction of a south crater wall by the slope failures that are thought to have produced the large debris avalanche.

The oldest pyroclastic-flow deposit of Cougar age recognized in the Swift Creek valley consists of ash and blocks of hypersthene-hornblende pumice, formed by a pyroclastic flow which moved southward from the volcano as far as the Lewis River valley. The deposit is about $20 \mathrm{~m}$ thick where exposed in a deep roadcut near the southwest end of the Forest Road 90 bridge across the Swift Creek valley (locality 43 ) (fig. 8). Lightto medium-gray pumiceous dacite makes up about 55 percent of the clasts in this deposit; the rest are of nonvesicular rock. Some of the blocks are breadcrusted, and almost all clasts in the uppermost few meters of this deposit are pumiceous. The deposit is directly and conformably overlain by a similar one 8-10 $\mathrm{m}$ thick in which nonvesicular rock makes up about 65 percent of the clasts, and the remainder are of dark- and light-gray pumiceous dacite. Some breadcrusted blocks of this rock have a maximum diameter of $1.8 \mathrm{~m}$.

A pyroclastic-flow deposit consisting of blocks of dark-gray hypersthene-hornblende pumice is exposed in a borrow pit (locality 46) on the south side of the Lewis River valley about $1.5 \mathrm{~km}$ west of Swift Dam (Hyde, 1975, p. 13), where it is about $12 \mathrm{~m}$ thick. Pumice makes up about 85 percent of the clasts in this deposit. Charcoal from the deposit at the borrow pit yielded a radiocarbon date of $20,350 \pm 350$ years $(\mathrm{W}-2540)$. The 


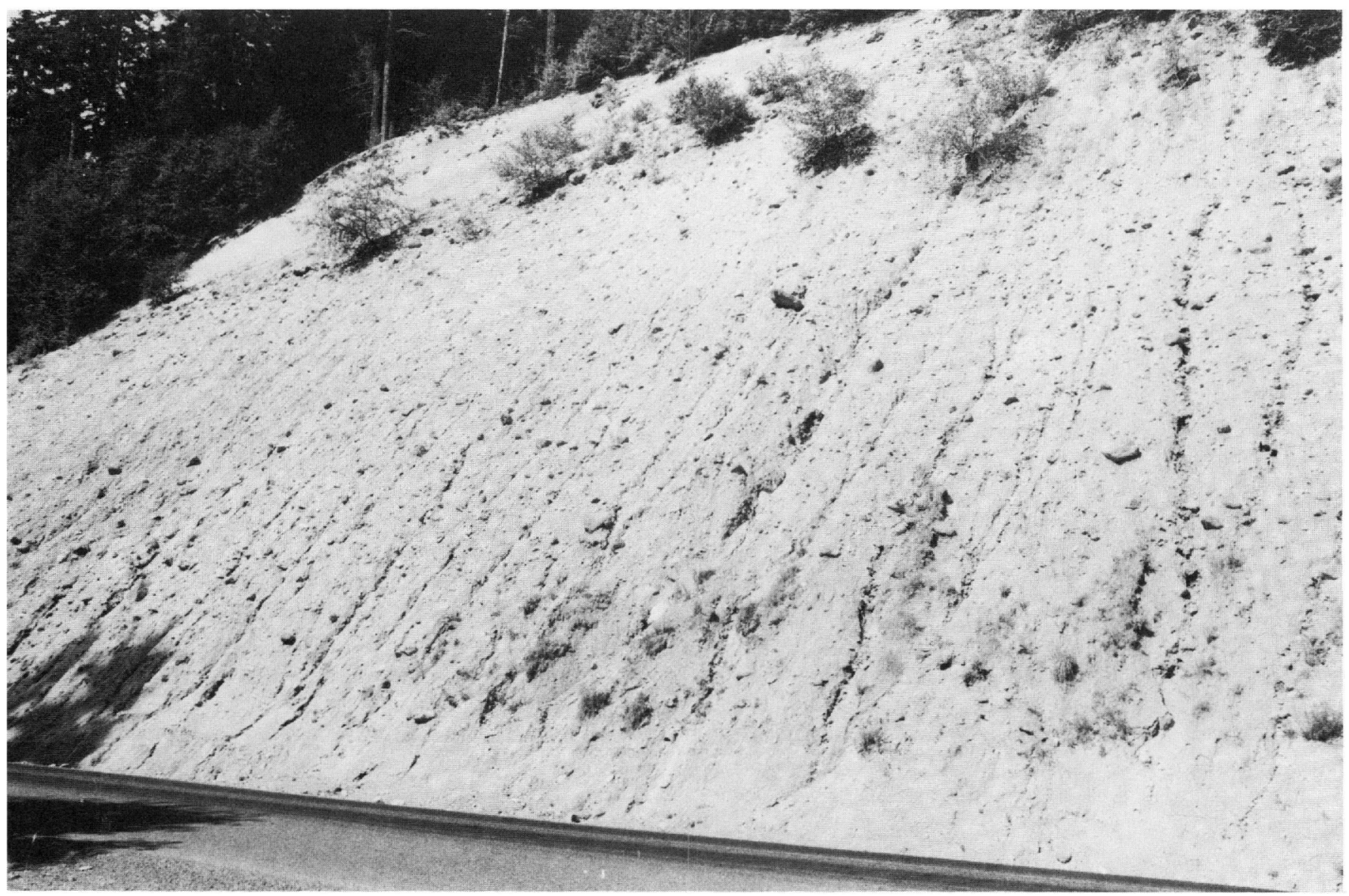

Figure 8.-Pyroclastic-flow deposit of Cougar age exposed in cut along Forest Road 90 at south end of bridge across Swift Creek about $12 \mathrm{~km}$ south of the summit of Mount St. Helens. The largest block in the upper center of the photograph is about $1 \mathrm{~m}$ across.

pyroclastic flow extended at least $14 \mathrm{~km}$ from Mount St. Helens and was one of the longest such flows in the history of the volcano. Samples of pumice clasts from this pyroclastic-flow deposit and one overlying it both had a $\mathrm{SiO}_{2}$ content of 62.6 percent (samples 2 and 3 , app. A).

This pyroclastic-flow deposit is overlain by tephra of sets $M$ and $K$ and by another pyroclastic-flow deposit of hypersthene-hornblende pumice. The radiocarbon age of charcoal from this second pyroclastic-flow deposit is $18,560 \pm 180$ years ( $W-2413$; Hyde, 1975).

The radiocarbon ages of these large pyroclastic flows suggest that they occurred just before or during the time that alpine glaciers in the Mount St. Helens area reached their maximum extents. The pyroclastic-flow deposits were, however, not seen in contact with glacial drift of Fraser age.

Lahars and alluvium derived from pyroclastic flows and other products of volcanism during the Cougar eruptive stage temporarily filled the Lewis River valley to a height of $90 \mathrm{~m}$ above the river at least as far downstream as the area occupied by the upper end of Lake Merwin. Some of the lahars are preserved beneath a terrace $1-3 \mathrm{~km}$ west of Yale Dam; the terrace is 70-75 $\mathrm{m}$ above the level of the Lewis River prior to the construction of Merwin Dam and creation of Lake Merwin. Brown silt that may be loess overlies the terrace deposits and contains scattered pumice lapilli at its base, probably of set M (p. 29).

A lahar within the fill of Cougar age is exposed in a borrow pit about $1 \mathrm{~km}$ west of Yale Dam (locality 53). It contains large masses of unconsolidated sand and gravel and blocks as much as $2.5 \mathrm{~m}$ in diameter of semiconsolidated pyroclastic-flow deposits. This lahar has vertical "pipes" of openwork as much as $10 \mathrm{~cm}$ wide and as long as $4 \mathrm{~m}$. Some of these extend to the top of the lahar and others seem to terminate within the deposit.

Lahars that are probably part of the valley fill of Cougar age also are exposed in a gravel pit near the mouth of Speelyai Creek. This fill was deposited in a valley that is now followed by Speelyai Creek, but the 
valley was formerly occupied by the Lewis River. The present valley of the Lewis probably originated as an ice-marginal channel during a pre-Fraser glaciation. Both channels were filled by lahars during Cougar time, and it may be a coincidence that the present river follows the southernmost course.

\section{WEST SIDE OF THE VOLCANO}

Deposits of Cougar age are exposed along a logging road on the south side of the South Fork Tbutle River valley about $5 \mathrm{~km}$ west of the base of the volcano (locality 71) where a succession of pumiceous and lithic pyroclastic-flow deposits is overlain by till of Fraser age. Upslope to the east, the till forms a west-trending lateral moraine along the south valley wall (locality 70 ). Pumice from one of the pyroclastic-flow deposits contains hornblende and hypersthene accompanied by a small amount of augite. The vertical distribution of pyroclastic-flow deposits and till in the South Fork Toutle River valley suggests that the valley-filling succession of volcanic deposits was trenched to the level of the flood plain before a glacier moved downvalley and built the lateral moraine.

A lahar tentatively assigned to the Cougar eruptive stage has been observed by K. M. Scott (written commun., 1984) in the Cowlitz River valley about $3 \mathrm{~km}$ northwest of Castle Rock. The deposit is at least $1.3 \mathrm{~m}$ thick and is overlain by rhythmically bedded fluvial slackwater sediments that probably represent the downvalley correlative of scabland flood deposits of Fraser age in eastern Washington. Scott suggested that the lahar was large enough to have reached the Columbia River.

\section{SOUTHEAST SIDE OF THE VOLCANO}

Pyroclastic flows and lahars extended southeastward into the valley of Pine Creek during the Cougar eruptive stage and may also have moved into Ape Canyon and the Smith Creek valley. A pyroclastic flow of Cougar age that evidently spilled over the Pine Creek-Smith Creek divide southeast of Mount St. Helens is exposed in a roadcut a few hundred meters north of Forest Road 83 (locality 20). The deposit, $2.4 \mathrm{~m}$ thick, consisting chiefly of blocks of hypersthene-hornblende pumice (fig. 9), overlies colluvium derived from local bedrock. The deposit crops out in a $30^{\circ}$ east-facing slope that leads down to the northeast-trending segment of the Muddy River valley. The ridge crest upslope from the deposit trends northward; thus, a pyroclastic flow moving southeastward from the volcano must have overridden the ridge at an oblique angle. Other deposits of this pyroclastic flow were not recognized.
Two pumiceous pyroclastic flows of post-K, pre-S age crop out in the Pine Creek valley about $10 \mathrm{~km}$ southeast of the base of the volcano. They are exposed in a cut along an abandoned logging road on the south side of a tributary of Pine Creek (locality 36). The lower deposit is about $0.7 \mathrm{~m}$ thick and overlies an oxidized zone developed on tephra set K (D. R. Mullineaux, oral commun., 1977). The deposit consists of pumice and lithic lapilli in a loose matrix of pumiceous and lithic ash; ironmagnesium silicate minerals in the pumice include hypersthene and hornblende in addition to a very small amount of augite. Charcoal collected from $5 \mathrm{~cm}$ above the base of the pyroclastic-flow deposit yielded a radiocarbon age of $19,160 \pm 250$ years (Crandell and others, 1981). The pyroclastic-flow deposit is overlain by $0.7 \mathrm{~m}$ of compact, unstratified lithic ash, above which is a pyroclastic-flow deposit $0.8 \mathrm{~m}$ thick that consists

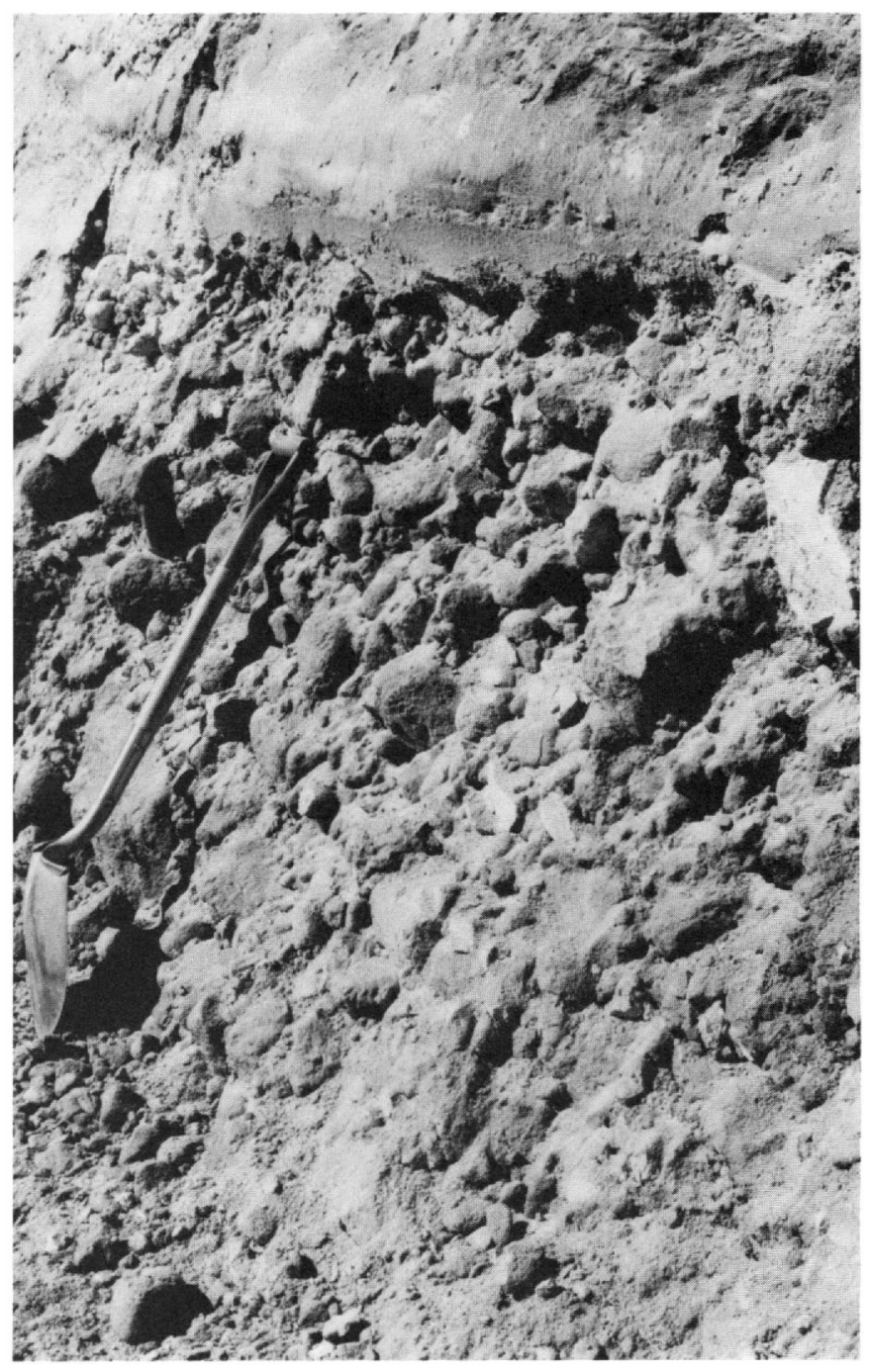

Figure 9.-Pyroclastic-flow deposit of Cougar age consisting of pumice blocks with almost no ash matrix. 
of pumice blocks as much as $20 \mathrm{~cm}$ in diameter in an ash matrix. Iron-magnesium silicate phenocrysts in the pumice include hypersthene as well as minor amounts of augite and hornblende. The extents of these two pyroclastic-flow deposits are not known.

\section{NATURE AND AGE OF VOLGANISM}

The Cougar eruptive stage seems to have begun with the eruption of hornblende-hypersthene dacite, represented by lahars on the south side of the volcano. These lahars apparently were followed by a large debris avalanche derived from rocks of Ape Canyon age at the volcano. The debris avalanche was followed by more lahars of hornblende-hypersthene dacite, and some of these evidently carried hot rock debris. The next inferred event was the eruption of a lava flow of high-silica andesite that moved down the south flank of the volcano, perhaps localized by a previous disruption of a south crater wall or a south flank of the volcano that had produced the debris avalanche. The lava flow was followed by pumiceous pyroclastic flows of hypersthenehornblende dacite on the southeast, south, and west sides of the volcano and by the eruption of tephra sets $\mathrm{K}$ and $\mathrm{M}$.

Pyroclastic flows and lahars moving into the Lewis River valley filled it to a height of as much as $115 \mathrm{~m}$ at some places, and farther downstream lahars aggraded the valley to form a fill $70-75 \mathrm{~m}$ above the river at the site of Yale Dam. This fill is believed to have been trenched by the Lewis River as soon as the fragmental material ceased to be contributed by the volcano to the drainage system (Hyde, 1975, p. 19). The valley fill has been recognized downstream only as far as Speelyai Bay near the upper end of Lake Merwin, but during Cougar time lahars and fluvial deposits undoubtedly aggraded the Lewis River downstream to its confluence with the Columbia.

Flowage deposits of Cougar age have not been recognized on the north side of the volcano, but this probably is a consequence of subsequent erosion and burial because a lahar of Cougar(?) age is present in the Cowlitz River valley near Castle Rock.

Little can be inferred about the actual duration of the Ape Canyon-Cougar interval between the radiocarbon bracketing dates of about 20,350 and 36,000 years, and the age limits of the Cougar eruptive stage are poorly defined because charcoal has been found in only three deposits. According to D. R. Mullineaux (oral commun., 1979), tephra set $K$ contains several oxidized zones that probably represent periods of weathering during accumulation of the tephra. Mullineaux finds that tephra set $\mathrm{K}$ has few well-defined beds and commonly is mixed.
He attributes these features to deposition of the tephra during conditions of relatively severe climate and unstable ground that accompanied the climax of the Fraser glaciation.

At the end of the eruptive stage, the summit of the volcano was at an altitude above $1,825 \mathrm{~m}$, as indicated by the uppermost outcrop of the andesite lava flow of Cougar age.

\section{GLACIAL DEPOSITS OF FRASER AGE}

Cirque and valley glaciers developed at Mount St. Helens and in the adjacent mountains during the last major glaciation. Altitudes of cirque floors suggest that accumulation areas for these glaciers were at and above about $975 \mathrm{~m}$.

A glacier that moved southward from the Mount St. Helens volcanic center extended about $1.5 \mathrm{~km}$ south of June Lake and probably terminated near the north base of Marble Mountain at an altitude of about $800 \mathrm{~m}$. This glacier built small lateral moraines (localities 39,40 ) that jut southward from rock knobs on both sides of the June Lake valley. Farther west, a south-moving glacier deposited till that is more than $30 \mathrm{~m}$ thick along Forest Road 83 where that road crosses the valley of West Fork Swift Creek (locality 47) (figs. 10, 11). This till consists predominantly of rock debris derived from the volcano. At the top it is locally oxidized to a depth of $10-25 \mathrm{~cm}$, and the till is buried by pyroclastic flows of Swift Creek age that are interbedded with tephra of set $\mathrm{S}$. The till is not overlain by the pumiceous pyroclasticflow deposit of Cougar age that is about 18,560 years old, which suggests that the glacial advance occurred some time after that date. The presence of set $\mathrm{S}$ tephra above the till indicates that the advance occurred some time before 13,000 years ago. The glacier that deposited the till may have terminated near the site of Ape Cave (locality 48), $1.5 \mathrm{~km}$ farther downvalley at an altitude of about $600 \mathrm{~m}$ (Hyde, 1975). This glacier also formed moraines that are crossed by Forest Road 81 just west of the valley of West Fork Swift Creek (locality 49) (Hyde, 1975, p. 7, fig. 2).

South of the volcano, basalt at an altitude of about 900 $m$ on the northwest flank of Marble Mountain is glacially smoothed and striated. One or more small glaciers must have been present on the higher parts of the mountain during Fraser time, but their extents are not known.

A glacier that headed at the volcanic center during Fraser time moved westward down the South Fork Toutle River valley, where it is recorded by a lateral moraine at a height of about $180 \mathrm{~m}$ above the valley floor at locality 70 . The moraine overlies a thick sequence of pyroclastic-flow deposits and lahars and is overlain by 


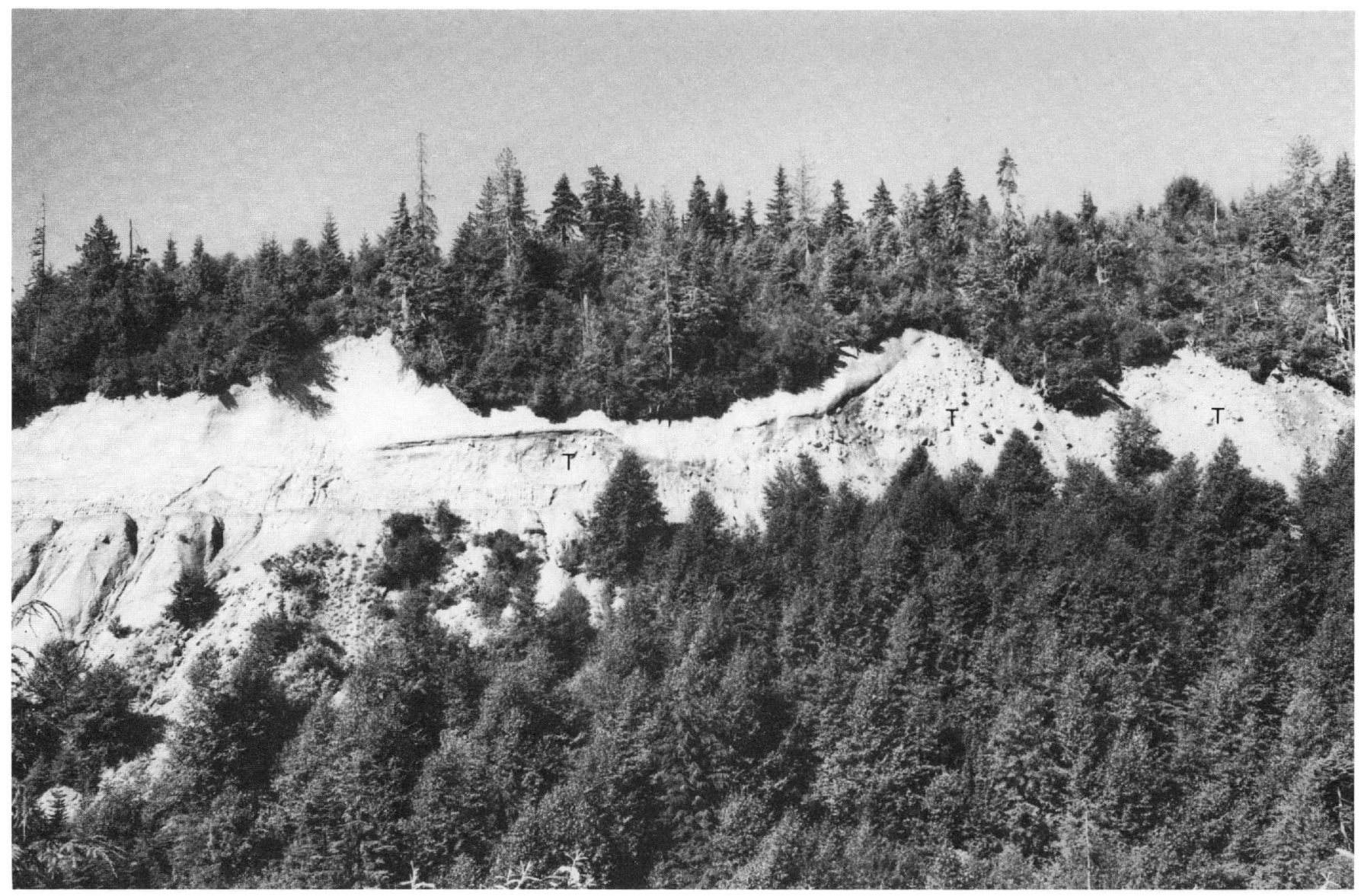

Figure 10.-View westward of till of Fraser age (T) exposed in cut along Forest Road 83 near the bridge across the West Fork of Swift Creek. The south-sloping surface of the till may be the front of a moraine. Most fine-grained units above the till were deposited by pyroclastic flows of Swift Creek age.

tephra of set $\mathrm{S}$. The glacier was joined by small valley glaciers that headed in cirques along the ridge that borders the south side of the South Fork valley.

Till that crops out in a roadcut just north of McBride Lake (locality 55) contains no rock debris from Mount St. Helens even though the till is interbedded with fragmental deposits derived from the volcano. Abundant clasts of a fine-grained black igneous rock in the till evidently were derived from Tertiary rocks that form the valley wall and ridge south of McBride Lake. A glacier moving northward from this ridge and valley wall may also have deposited till $1 \mathrm{~m}$ thick, which can be seen overlying striated bedrock at a rock quarry on the southeast spur of Goat Mountain (locality 60). This till also lacks rock fragments derived from the volcano. Striations on the bedrock beneath the till trend almost directly north. These two outcrops of till evidently represent a small local glacier. Their presence suggests that glaciers from the volcanic center did not reach as far southwest as these localities in the Kalama River valley, both of which are at an altitude of about $850 \mathrm{~m}$.
Farther down the Kalama River valley, a small lateral moraine of Fraser age that borders the south side of the Dry Creek valley (locality 58 ) was formed by a small glacier that originated near Cinnamon Peak. This moraine is at an altitude of about $500 \mathrm{~m}$. Several outcrops of till at an altitude of about $975 \mathrm{~m}$ were noted northeast of Cinnamon Peak along a logging road on the south side of the ridge south of $\mathrm{McBride}$ Lake.

A glacier that moved northward from Goat Mountain into the valley of Coldspring Creek deposited till that crops out at an altitude of about $900 \mathrm{~m}$ along a logging road (locality 67). Rock debris in the till consists of biotite-hornblende dacite derived from Goat Mountain. The glacier may have extended down the Coldspring Creek valley to join the South Fork Toutle glacier.

The laterally directed blast of May 18, 1980, stripped a mature forest from a prominent lateral moraine nearly $300 \mathrm{~m}$ above the floor of the North Coldwater Creek valley. During the late spring and summer of 1980 , South Coldwater Creek cut down to bedrock and exposed extensive deposits of till beneath tephra on the valley floor. 


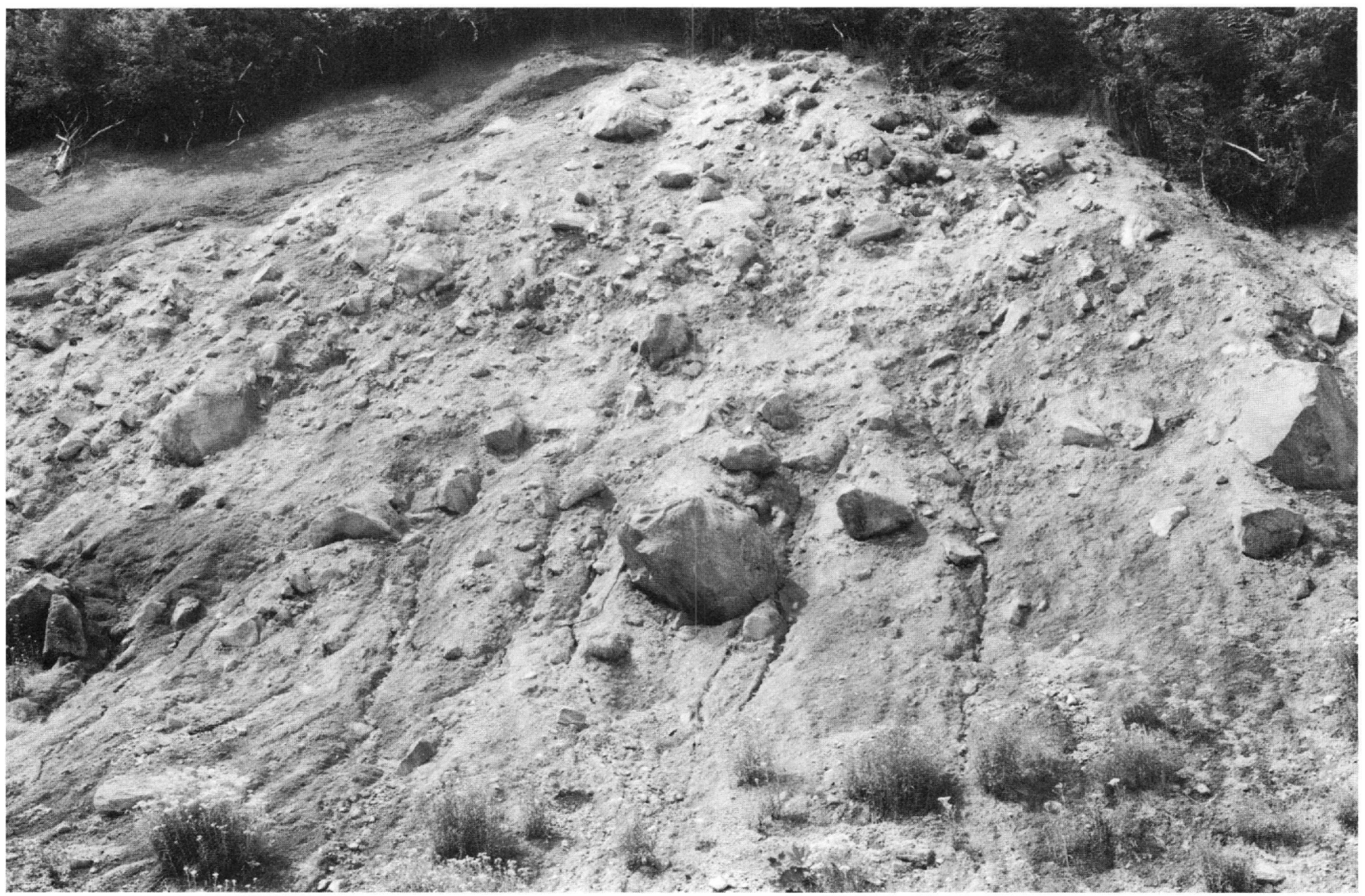

FIGURE 11.-Till of Fraser age exposed along Forest Road 83 (fig. 10) contains glacially faceted and striated cobbles and boulders in a compact matrix of silt and sand. The large boulder in the center of the photograph is about $1 \mathrm{~m}$ in diameter.

Glaciers originating in the Coldwater Creek drainage basin merged with another glacier in the North Fork Toutle River valley, and together they extended about $16 \mathrm{~km}$ farther downvalley. The North Fork Toutle glacier formed lateral moraines on both valley walls about $3 \mathrm{~km}$ east of Camp Baker and probably terminated between Deer Creek and Camp Baker at an altitude of about $320 \mathrm{~m}$.

East of the volcano, a glacier extended southward down the valley of Smith Creek to an altitude at least as low as $730 \mathrm{~m}$ and probably to $600 \mathrm{~m}$. Till deposited by this glacier is well exposed beneath tephra of set $S$ and younger sets above a rock quarry adjacent to Forest Road 92 (locality 6) (fig. 12).

A large glacier that headed on Mount Adams and in the area to the west moved westward down the Lewis River valley, terminating about $2.5 \mathrm{~km}$ upvalley from the east end of Swift Reservoir. A lateral moraine formed near the terminus of the glacier is crossed by Forest Road 90 near Curley Creek (locality 30). Till in the moraine is oxidized strong brown $(7.5 Y R 5 / 6)$ to a depth of about $75 \mathrm{~cm}$; the unoxidized color of the till is very dark grayish brown (2.5Y 3/2). A more conspicuous lateral moraine, about $60 \mathrm{~m}$ above the Lewis River, is crossed by the road $1 \mathrm{~km}$ northeast of the Curley Creek bridge. Just east of this moraine, Forest Road 51 crosses another lateral moraine on the south wall of the Lewis River valley about $240 \mathrm{~m}$ higher than the river.

Till of Fraser age on the upland northwest of the Lewis River crops out near the head of Pepper Creek at a rock quarry (locality 27), about $290 \mathrm{~m}$ above the floor of the adjacent Lewis River valley. The till is oxidized to dark yellowish brown (10YR 4/4) to a depth of $33 \mathrm{~cm}$, below which the unoxidized color is very dark brown (10YR 3/3). The till is overlain by more than $1 \mathrm{~m}$ of tephra of set $S$ and younger sets. At this point, the Lewis River glacier was about $6 \mathrm{~km}$ from its inferred downvalley terminus.

Cobble and boulder gravel, rich in vesicular basalt, forms a terrace $43 \mathrm{~m}$ above the Lewis River near the Forest Road 9059 bridge across the Lewis (locality 29). The gravel, probably part of an outwash valley train, is oxidized to a depth of about $60 \mathrm{~cm}$ and is overlain 


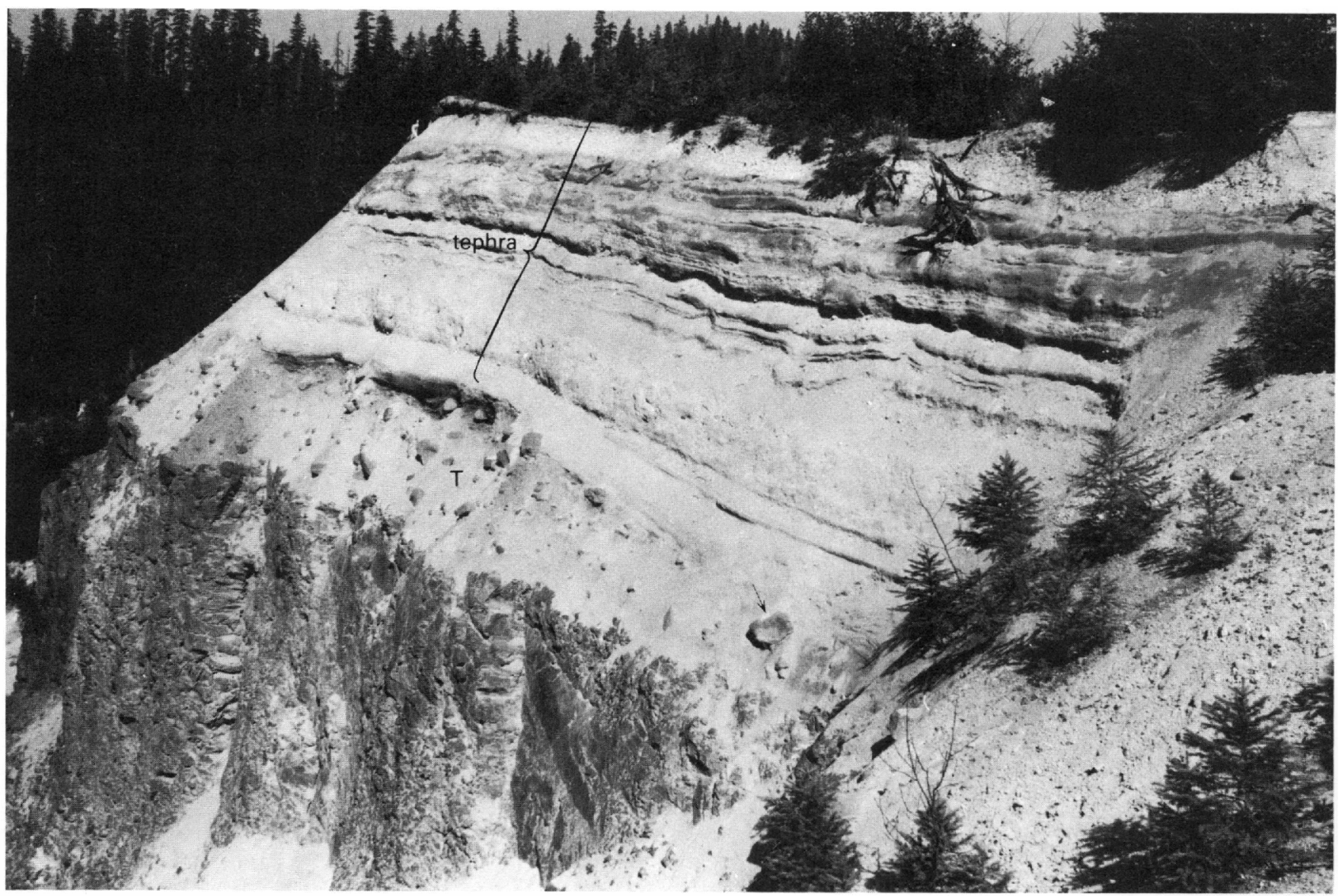

FigurE 12,-Bouldery till (T) of Fraser age overlain by tephra of sets $S$ through $W$ upslope from a rock quarry in the Smith Creek valley about $9 \mathrm{~km}$ northeast of the summit of Mount St. Helens. The large boulder (arrow) is about $50 \mathrm{~cm}$ in diameter. Photograph taken in 1978.

by tephra of set $S$ and a lahar of Swift Creek age from Mount St. Helens (Crandell and Mullineaux, 1973, p. 11-12).

Although eruptive activity occurred at Mount St. Helens between 18,000 and 20,000 years ago, while glacial ice evidently covered or partly covered the volcanic center, no evidence was found of interactions between volcanic phenomena and glaciers.

\section{SWIFT CREEK ERUPTIVE STAGE}

\section{DEPOSITS}

The Swift Creek eruptive stage began about 13,000 years ago and ended before 10,000 years ago. Deposits of this stage locally overlie till and outwash gravel of Fraser age; the stratigraphic sequence of these deposits is summarized in table 5. The deposits include some of those Hyde (1975) described as part of his Swift Creek volcanic assemblage; those younger than tephra set $\mathrm{S}$ were included in the older part of the Pine Creek assemblage by Crandell and Mullineaux (1973; p. 41).

\section{SOUTH SIDE OF THE VOLCANO}

Deposits of Swift Creek age are especially well exposed in the valley of Swift Creek along and below Forest Road 83 (locality 47) (fig. 3) where a succession of pre-S pyroclastic-flow deposits with a combined thickness of at least $28 \mathrm{~m}$ overlies till of Fraser age. An oxidized zone about $25 \mathrm{~cm}$ thick in the uppermost part of the till indicates that some weathering occurred before the overlying volcanic deposits were formed. A sample of a prismatically jointed block of nonvesicular dacite from the uppermost pyroclastic-flow deposit (unit 6 , measured section 1) had a $\mathrm{SiO}_{2}$ content of 67.2 percent (sample 4, app. A). Above tephra set $\mathrm{S}$ at this locality is a pyroclastic-flow deposit about $1 \mathrm{~m}$ thick which is overlain by tephra set $\mathbf{J}$ and younger tephra.

Near the northeast end of the Forest Road 90 bridge over the Swift Creek valley (locality 42), charcoal from 
TABLE 5.-Stratigraphic sequence of deposits formed during the Swift Creek eruptive stage [Age of tephra set $\mathrm{J}$ is from Mullineaux (1986). Predominant iron-magnesium silicate phenocrysts in tephra sets are from Mullineaux and Crandell (1981). hy, hypersthene; hb, hornblende; ag, augite; cm, cummingtonite]

\begin{tabular}{lc} 
Deposits & $\begin{array}{c}\text { Approximate radiocarbon } \\
\text { age (years B.p.) }\end{array}$ \\
\hline Tephra set .T (hy, hb) & $11,000-10,000$ \\
Pyroclastic-flow deposits and lahars (hy, hb, ag)-- & $12,000-11,500$ \\
Tephra set S (cm, hb, hy) & 13,000 \\
Pyroclastic-flow deposits and lahars (cm, hb) & 13,000
\end{tabular}

a pre-S pumiceous pyroclastic-flow deposit yielded a radiocarbon date of $12,910 \pm 160$ years $(\mathrm{W}-3141)$. A lenticular lahar beneath this deposit is underlain by silt and fluvial gravel that is weathered (Hyde, 1973). These deposits all lie within a valley cut into a thick pumiceous pyroclastic-flow deposit of Cougar age.

Measured section 1

[Location-roadcut along Forest Road 83 on west side of Swift Creek valley at locality 47 in the SE1/4NE $1 / 4$ sec. 5, T. 7 N., R. 5 E. Units 2 and 3 crop out downslope from the road] Thickness

Deposits of Swift Creek age:

11. Tephra of set $\mathrm{J} \ldots \ldots \ldots$. . . . . . . . . . . .

10. Pyroclastic-flow deposit: angular and subangular fragments as large as $50 \mathrm{~cm}$ in diameter of gray and reddish-gray hornblende-hypersthene dacite in reddish-gray matrix of fine lithic ash

9. Tephra of set S: yellow pumiceous ash and lapilli as much as $6 \mathrm{~cm}$ in diameter, and lithic fragments as much as $2 \mathrm{~cm}$ in diameter; includes $2 \mathrm{~cm}$ of fine ash at top

8. Pyroclastic-flow deposit: angular to subrounded fragments as much as $40 \mathrm{~cm}$ in diameter of cummingtonite-hormblende pumice and gray hornblende dacite in matrix of fine gray ash; some dacite blocks prismatically jointed; about twothirds of clasts are pumice and one-third are nonvesicular rock, a few of which are from Tertiary bedrock

7. Interbedded lahars and fluvial deposits

6. Pyroclastic-flow or pyroclastic-surge deposit: rock fragments $5 \mathrm{~cm}$ or less in diameter of hornblende dacite and cummingtonite-hornblende pumice in matrix of fine gray lithic ash; about two-thirds of clasts are of nonvesicular rock, a few of which were derived from bedrock of Tertiary age, and the remainder are pumice; lenticular

5. Pyroclastic-flow deposit: similar to unit 4; lenticular 2.0-4.0

4. Lahars interbedded with thin fluvial(?) deposits: contain pumice and nonvesicular rock fragments as much as $35 \mathrm{~cm}$ in diameter; lenticular . . . . . .

3. Pyroclastic-flow deposit: clasts of nonvesicular gray dacite as large as $50 \mathrm{~cm}$ in diameter in reddish-
Deposits of Swift Creek age-Continued gray pumiceous and lithic ash matrix; some clasts prismatically jointed $\ldots \ldots \ldots \ldots \ldots \ldots$

2. Pyroclastic-flow deposit: clasts of hornblendecummingtonite pumice and nonvesicular cummingtonite-hornblende dacite mostly less than $10 \mathrm{~cm}$ in diameter in matrix of brownish-gray pumiceous and lithic ash; some lithic clasts prismatically jointed

Deposits of Fraser age:

1. Till: compact mixture of angular to subrounded dacite fragments as much as $2 \mathrm{~m}$ in diameter chiefly derived from Mount St. Helens, in gray silt and sand matrix; oxidized yellowish brown in uppermost 10-25 cm; upper surface of till slopes southward ................... $>40.0$

Lahars of Swift Creek age that are both older and younger than tephra set $\mathrm{S}$ were described at several places in the Lewis River valley south of the volcano by Hyde (1975, p. 16-19).

Lahars moving down the Lewis River valley during Swift Creek time formed a fill similar to that of Cougar time, but generally not as high as the older fill. A valley fill of pre-S age underlies the terrace on which the community of Cougar is situated. Lahars at the top of this fill crop out in a pit at the west edge of the community and in the valley walls of Dog Creek farther west.

Three pre-S lahars are exposed in the walls of the gravel pit. The uppermost lahar is about $1 \mathrm{~m}$ thick and consists of dacite fragments in a lithic sand matrix. Most clasts are less than $3 \mathrm{~cm}$ in diameter at the base of the deposit, and the uppermost part consists mostly of sand and granule-sized material. This lahar is locally underlain by a lenticular sandy lahar that is as much as $40 \mathrm{~cm}$ thick. Beneath it, a third lahar is more than $5 \mathrm{~m}$ thick. Rock fragments in this lahar are as large as $10 \mathrm{~cm}$ in diameter, and the deposit grades upward into sand and granule-sized material. This lahar contains innumerable vertical openwork "pipes" (figs. 13, 14), 
which are as much as $50 \mathrm{~cm}$ long and 2-5 mm wide on the west side of the pit. Many are less than $10 \mathrm{~cm}$ long and terminate within the lahar. On the south side of the pit, "pipes" are as long as $1 \mathrm{~m}$ and as wide as $4 \mathrm{~cm}$. The "pipes" seem to be tabular rather than cylindrical; some were traced into the outcrop as far as $15 \mathrm{~cm}$. The orientation of these tabular "pipes" seems to be random in the horizontal plane. Five of the largest rock fragments found in the lahar were examined with a fluxgate magnetometer, and their TRM directions seemed to be random. The lack of independent evidence that the lahar was carrying any hot debris suggests that the openwork "pipes" were formed by escaping water rather than gases.

Lahars of Swift Creek age are also exposed in roadcuts along State Highway 503 on the north side of the Lewis River valley just north of the highway bridge over Lake Merwin (locality 54), where they are banked against deposits of Cougar age. One lahar was deep enough while moving to overtop the older, higher fill. Its deposit now crops out at a height of about $73 \mathrm{~m}$ above the present valley floor. The deposit can be seen in a roadcut $100 \mathrm{~m}$ southwest of the junction of Highway 503 and the Yale Dam access road, where it is $1 \mathrm{~m}$ thick and overlies brown silt (loess?) about $2 \mathrm{~m}$ thick. The brown silt overlies a layer of air-fall pumice lapilli, probably part of set $M$. The top of the main fill of Swift Creek age forms a terrace about $3 \mathrm{~m}$ lower than the top of the Cougar-age fill. Several hundred meters down the highway to the southwest, a small borrow pit exposes two sandy lahars separated by a nearly horizontal layer of pumiceous ash of set $S$ about $1 \mathrm{~cm}$ thick, which is about $5 \mathrm{~m}$ below the top of the Swift Creek fill terrace.

The presence of these deposits so high above the valley floor at the head of Lake Merwin implies that the Lewis River valley was aggraded by lahars downstream to its mouth during Swift Creek time. Remnants of this fill, however, have not been seen downvalley from Highway 503 .

\section{WEST SIDE OF THE VOLCANO}

Roadcuts and gullies reveal deposits of post-S pyroclastic flows and lahars that form a broad apron bordering the western base of the volcano. The apron slopes southwestward into the Kalama River valley where most deposits of Swift Creek age are covered by younger units. Deposits of the apron also extend westward down the valley of Coldspring Creek, where they form a fill that merged with deposits in the valley of South Fork Toutle River. A remnant of this fill is

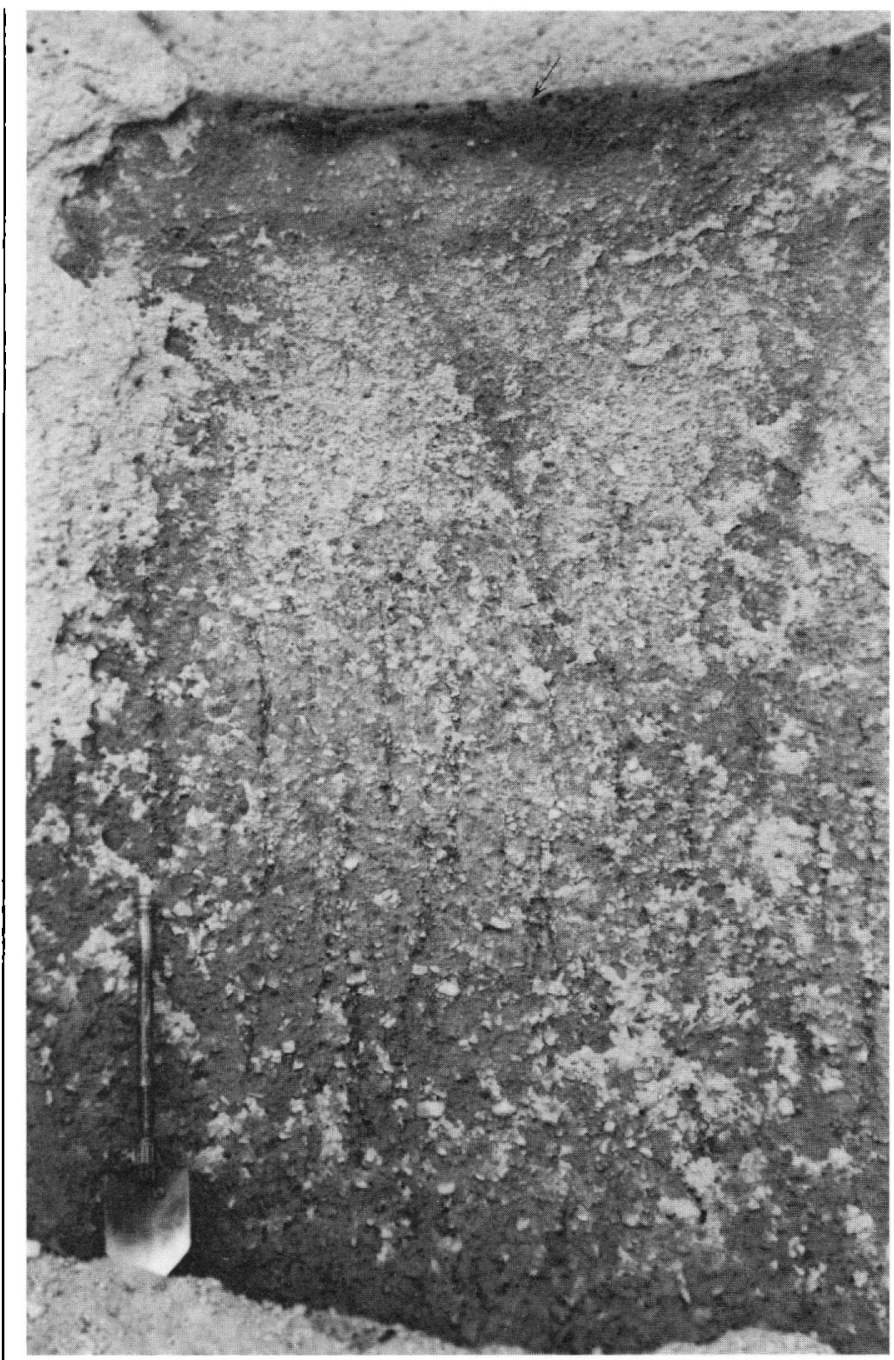

FIGURE 13.-Vertical "pipes" of openwork material in matrix of lahar of pre-S Swift Creek age exposed in west wall of gravel pit at Cougar. Arrow indicates the top of the lahar.

exposed in the east-facing front of a terrace in the Coldspring Creek valley (locality 69). Near the head of Coldspring Creek (locality 68), eight coarse rubbly deposits each $30 \mathrm{~cm}$ to more than $3 \mathrm{~m}$ thick are interbedded with layers of ash a few centimeters to nearly $50 \mathrm{~cm}$ thick. Rock samples taken from the coarse deposits in a cut along Forest Road 8123 had random directions of TRM; thus these deposits probably were emplaced as lahars. Clasts are wholly of nonvesicular dacite in some of these deposits, chiefly of pumice in others, and mixtures of both in still others. The lahars are overlain by tephra of set $\mathbf{J}$ and by younger tephra and pyroclastic-flow deposits. In a roadcut outcrop about $1.7 \mathrm{~km}$ to the south, east of Blue Lake, a pyroclastic-flow deposit more than $2 \mathrm{~m}$ thick below tephra of set $J$ has a pink top and contains prismatically jointed blocks of nonvesicular dacite. 


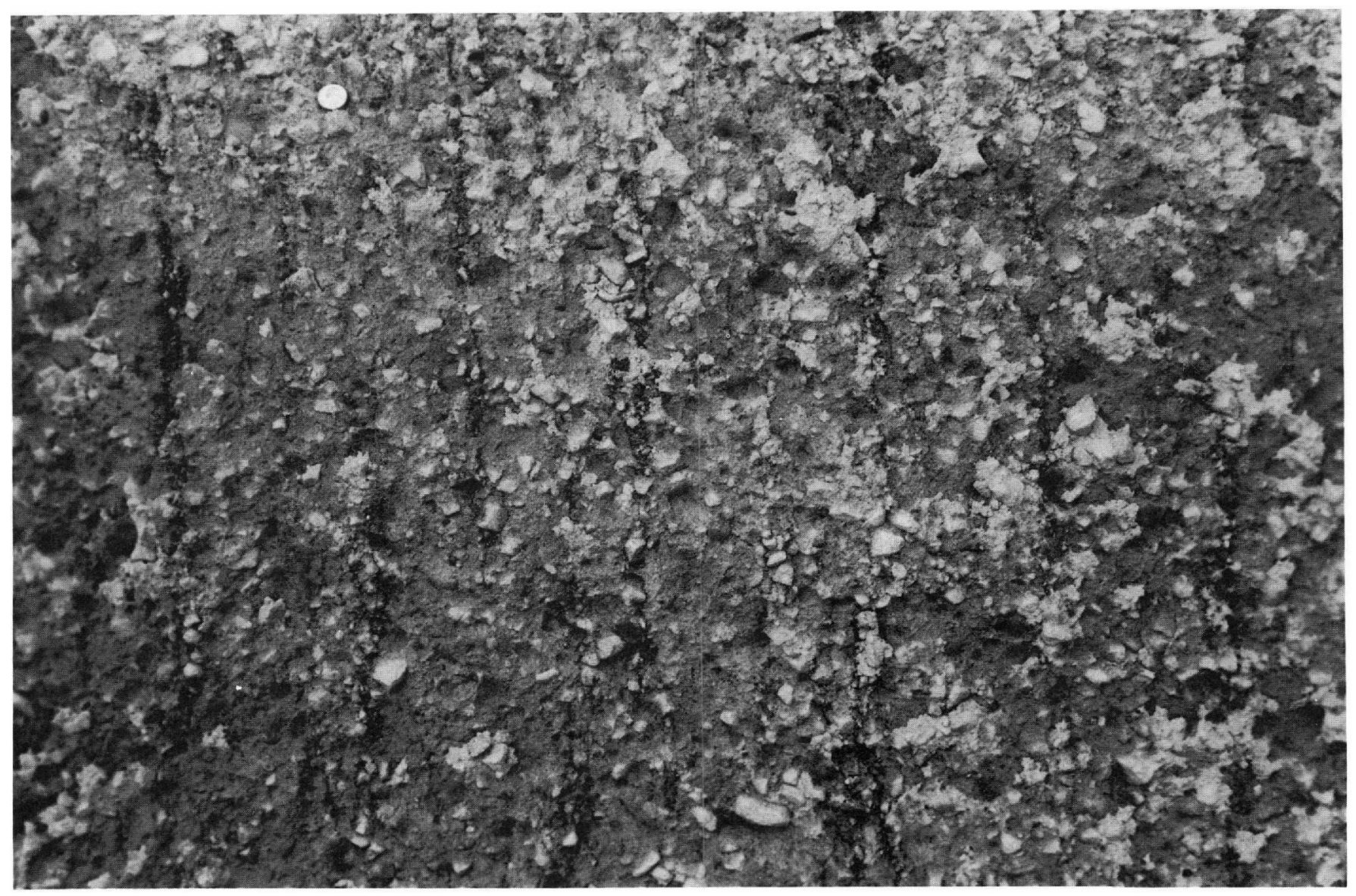

FIGURE 14.-Close-up photograph of vertical openwork "pipes" in lahar shown in figure 13. Quarter coin shows scale.

Deposits of Swift Creek age underlie remnants of a thick west-sloping fill near the head of the South Fork Toutle River. The deposits are at least $200 \mathrm{~m}$ thick where they crop out in the south wall of a valley tributary to the South Fork (locality 76). Lahars are interbedded there with lithic pyroclastic-flow deposits (fig. 15) and, near the top of the fill, with tephra derived from set $S$. The tephra, which occurs as lenses and beds throughout a vertical interval of nearly $15 \mathrm{~m}$, clearly was carried downslope by running water. The deposits of lithic pyroclastic flows below these fluvial beds can be recognized by the presence of reddish-gray zones at the tops of some individual units. Interbedded with the pyroclastic flows are layers of silt- to sand-sized ash a few centimeters to a meter thick that may be ash-cloud and pyroclasticsurge deposits. Other layers of coarse rubble less than a meter thick probably are lahars. When viewed from a distance, the deposits have a stratified appearance because they include many thin individual units.

Farther west, lahars of Swift Creek age younger than tephra set $\mathbf{S}$ form a terrace near the bottom of the South
Fork Toutle River valley. Charcoal from sand at the top of the lahars at a roadside borrow pit (locality 72) had a radiocarbon age of $12,270 \pm 90$ years ( $W-3145)$. The same terrace $3.5 \mathrm{~km}$ farther downvalley is about $12 \mathrm{~m}$ higher than the flood plain of the South Fork Toutle River.

A succession of six lahars exposed by erosion on and after May 18, 1980, has been recognized in the west bank of the Toutle River at Toutle Lake (Gilmore Corners) by K. M. Scott (written commun., 1984), who assigned them to the Swift Creek eruptive stage. The lahars range from 0.5 to more than $6 \mathrm{~m}$ in thickness and consist chiefly of nonvesicular rocks. Similar lahars of the same age were observed by Scott farther down the Toutle River valley.

\section{EAST SIDE OF THE VOLCANO}

Before the 1980 eruptions, a pyroclastic-flow deposit of post-S, pre-J age cropped out in a steep bank on the 


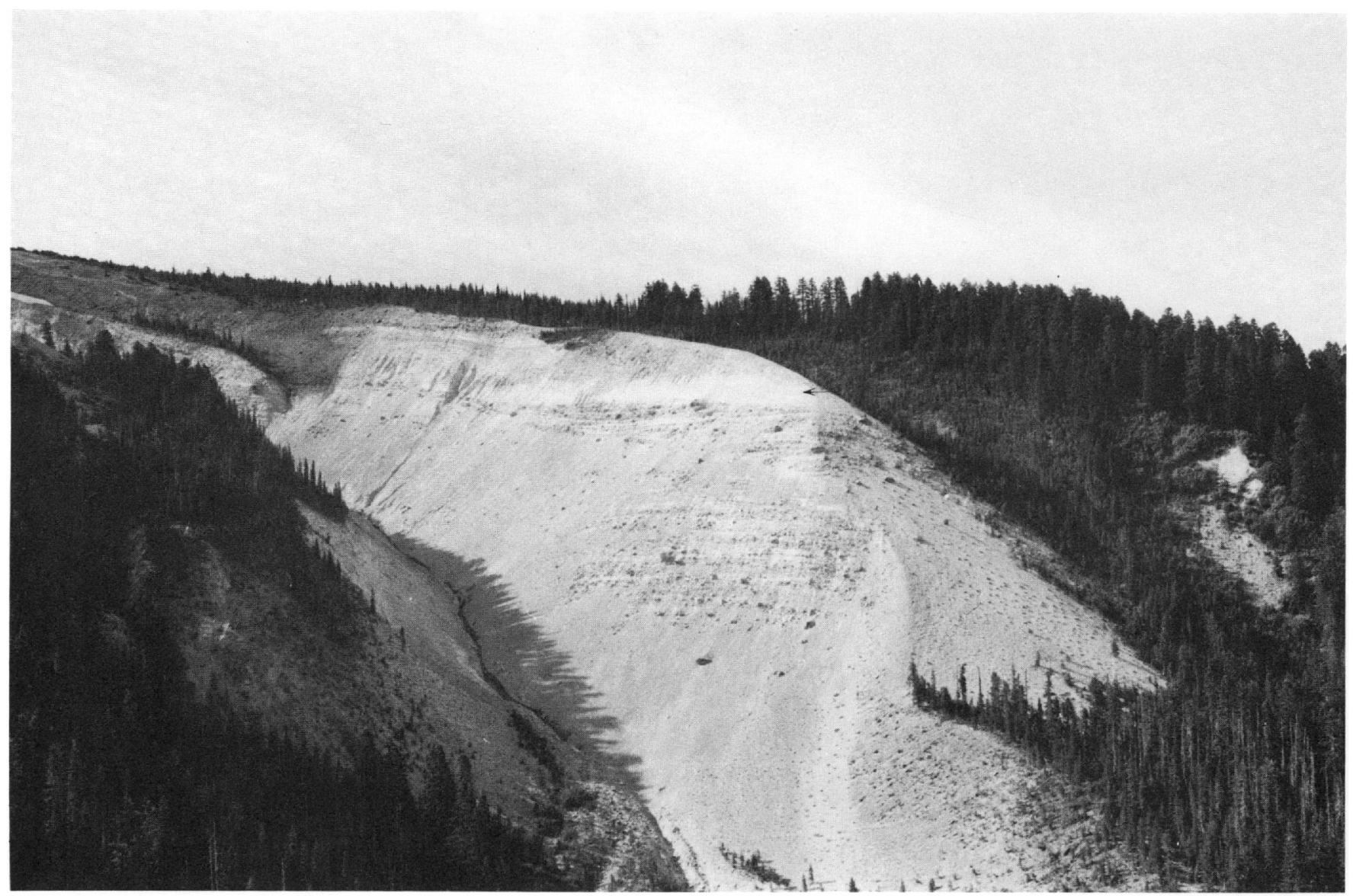

FIGURE 15.-Interbedded lahars and pyroclastic-flow deposits of Swift Creek age exposed in canyon tributary to South Fork Toutle River (locality 76). Fluvial deposits of pumice derived from tephra set $S$ are indicated by arrow. Photograph taken in 1977.

east side of Smith Creek at locality 12 (fig. 16). The principal rock type in the deposit was gray dacite that contained hypersthene, hornblende, and augite; some clasts of this rock were prismatically jointed and as large as $30 \mathrm{~cm}$ in diameter. Chemical analysis of a prismatically jointed block from this deposit contained 64.4 percent $\mathrm{SiO}_{2}$ (sample 5, app. A). The deposit was more than $10 \mathrm{~m}$ thick and its base was below the level of Smith Creek.

About $0.5 \mathrm{~km}$ upstream from this outcrop, a succession of five pre-J lahars underlay a terrace on the southwest side of the Smith Creek valley (locality 11) (measured section 2). The absence of a pyroclastic-flow deposit here suggests that these lahars postdate the pyroclastic-flow deposit farther downstream.

Farther south, a succession of post-S, pre-J pyroclastic flows and lahars moved into the Smith Creek valley through Ape Canyon. The resulting deposits crop out about $200 \mathrm{~m}$ north of Ape Canyon Creek in a cut along Forest Road 92 (locality 14), where they overlie more than $2 \mathrm{~m}$ of stream-deposited pumice. The two lowest deposits above the pumice consist of fragments of dacite in a sand and silt matrix. They are 0.6 and $1.1 \mathrm{~m}$ thick, respectively, and were formed either by pyroclastic flows or lahars. They are overlain by a pyroclastic-flow deposit(?) of similar texture that contains irregular masses of reddish-gray material. These deposits are in turn overlain by 3 or $4 \mathrm{~m}$ of fluvial sand and gravel that predate tephra set $\mathrm{J}$.

Pre-J deposits of Swift Creek age also crop out in the Smith Creek valley immediately south of Ape Canyon Creek (locality 15) in an east-facing scarp cut by floods and mudflows on May 18, 1980. They overlie alluvium consisting mostly of pumice derived from deposits of Ape Canyon age and include lithic lahars and pyroclastic-flow deposits, fluvial sand and gravel, and a pyroclastic-flow deposit $4 \mathrm{~m}$ thick of cummingtonitehornblende pumice. 


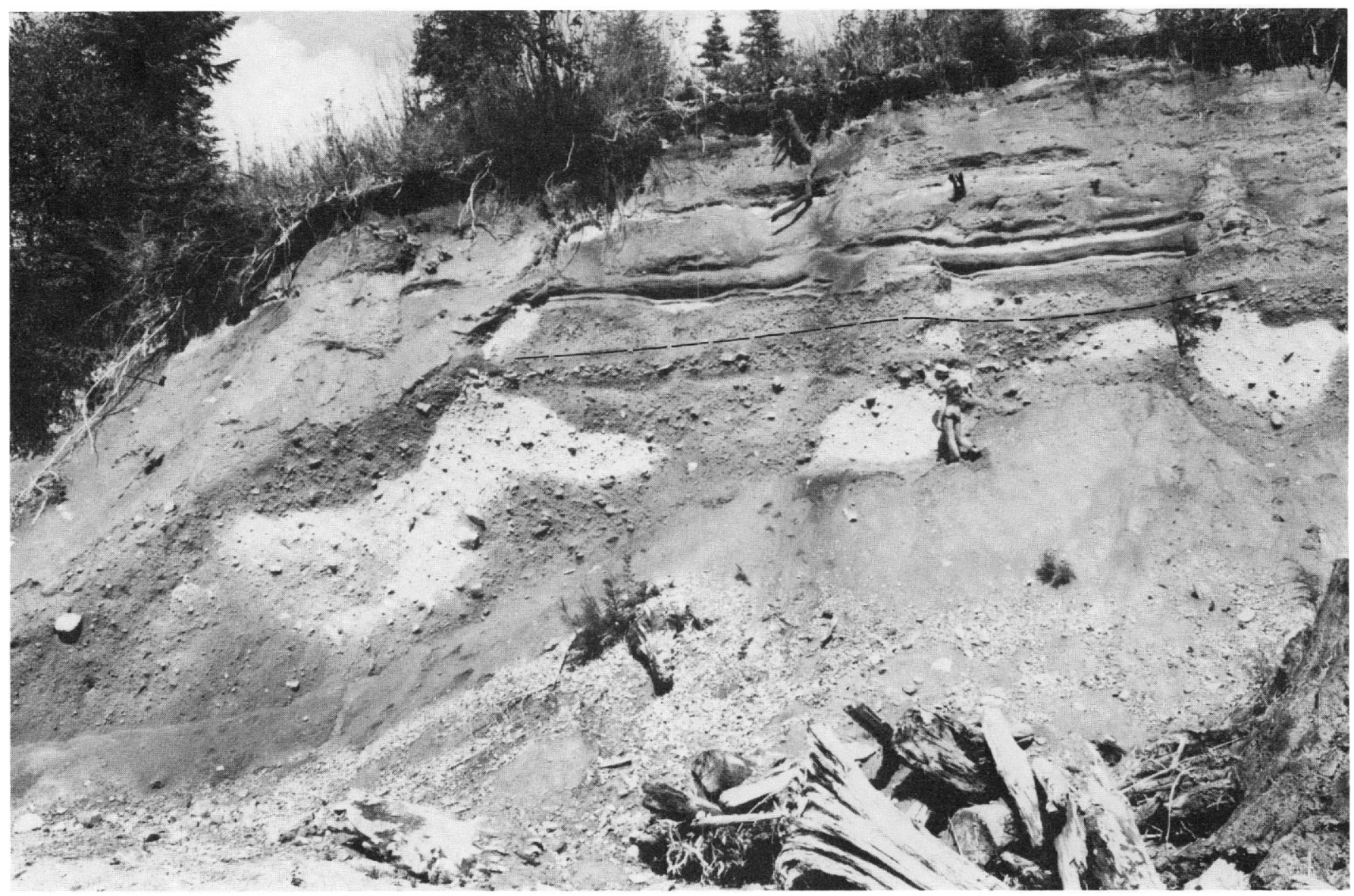

Figure 16.-Lithic pyroclastic-flow deposit (below dashed line) of Swift Creek age exposed in cutbank of Smith Creek (locality 12). Tephra sets $J$ through $W$ form the overlying stratified deposits. Photograph taken in 1978.

Measured section 2

[Location-roadcut in Smith Creek valley at locality 11 in the NE1/4SE1/4 sec. 30, T. 19 N., R. 6 E. Section measured before 1980]

9. Undifferentiated tephra Deposits of Swift Creek age:

8. Tephra of set $\mathbf{J}$

7. Lahar: unsorted mixture of angular and subangular dacite fragments as large as $30 \mathrm{~cm}$ in diameter in very compact matrix of gray sand

6. Ash, fine, brownish-gray, and scattered lapilli of nonvesicular rock and hypersthene-hornblende pumice

5. Lahar: chiefly compact poorly sorted medium to coarse sand and granules; contains scattered cobbles

4. Lahar: unsorted mixture of rock fragments mostly less than $3 \mathrm{~cm}$ in diameter in very compact matrix of gray silty sand; grades upward into chiefly fine sand

3. Lahar: unsorted mixture of subangular and subrounded rock fragments as large as $40 \mathrm{~cm}$ in diameter in compact gray sand matrix; largest

\section{Thickness (meters)}

5.0

.4

1.5

Deposits of Swift Creek age-Continued clasts derived from bedrock of Tertiary age; most other rock debris from Mount St. Helens

Thickness

(meters)

wahar: unsorted mixture of subangular and subrounded rock fragments mostly smaller than $3 \mathrm{~cm}$ in diameter in very compact gray sand matrix; contains scattered pumice lapilli

1. Lahar: unsorted mixture of angular and subangular rock fragments in compact gray sand matrix; contains scattered lapilli of hypersthene-hornblende pumice

Three lithic pyroclastic-flow deposits of Swift Creek age crop out along a former logging road on the north side of Ape Canyon about $100 \mathrm{~m}$ above the canyon floor (locality 13) (measured section 2) (fig. 17), and three similar deposits were noted on the south wall of the canyon about $2 \mathrm{~km}$ to the west and at about the same height above the canyon floor.

The height of these deposits above the canyon floor seemingly requires a special explanation. The 


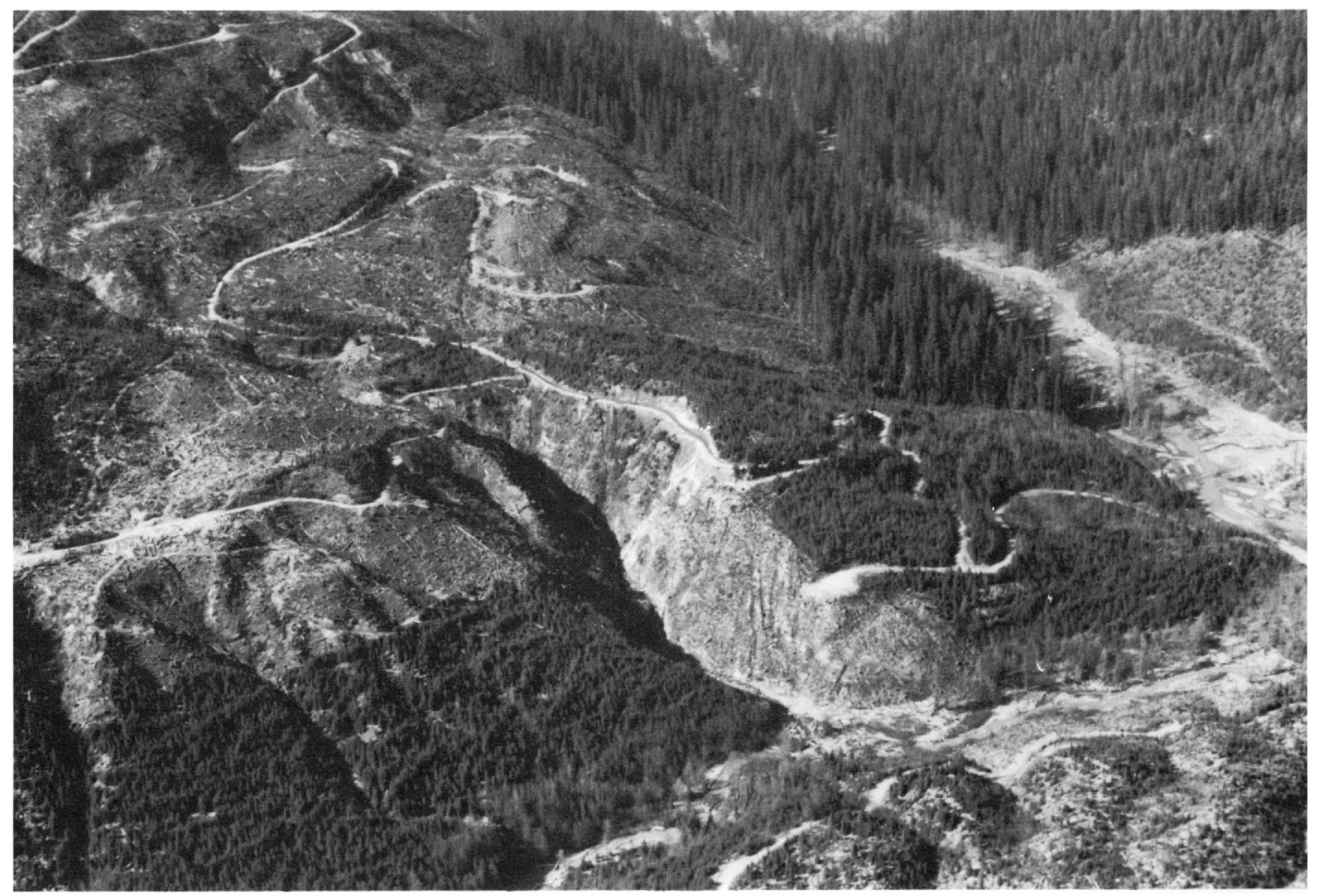

Figure 17.-Aerial view northeastward across lower part of Ape Canyon. Three thin pyroclastic-flow deposits lie between tephra sets S and $\mathrm{J}$ in roadcut (indicated by arrow), about $100 \mathrm{~m}$ above the canyon floor. Photograph taken in April 1980.

distribution of the deposits on the canyon walls cannot be explained by the presence of a shallower canyon during this part of the Swift Creek eruptive stage, because deposits of pyroclastic flows and lahars of similar age are found at the level of the canyon floor near the mouth of Ape Canyon. Moreover, there is no evidence of a thick fill of deposits either within Ape Canyon or in the Smith Creek valley at the mouth of the canyon. The canyon thus was not filled to a height of $100 \mathrm{~m}$ and subsequently reexcavated to its present level. Instead, the post-S, pre-J pyroclastic-flow deposits on the canyon walls seem to have been formed as veneers generally less than a meter thick.

\section{Measured section 3}

[Location-cut along logging road on north side of Ape Canyon at locality 13 in the NE1/4NW $1 / 4$ sec. 5, T. 8 N., R. 6 E.

11. Tephra of post-J age Thickness (meters) 11. Tephra of post-J age
Deposits of Swift Creek age: 10. Tephra of set $J$
Not determined Not determined
Deposits of Swift Creek age-Continued

9. Pyroclastic-flow deposit: unsorted mixture of angular and subangular fragments of hornblende dacite as large as $10 \mathrm{~cm}$ in diameter in ash matrix; contains abundant charcoal fragments including twigs and small branches that have a radiocarbon age of $12,100 \pm 110$ years ( $W-2868$ ); contains scattered pumice lapilli

8. Fine ash, mottled yellowish-brown and reddish-gray; contains scattered lithic and pumiceous lapilli

7. Pyroclastic-flow deposit: unsorted mixture of angular and subangular fragments of hypersthenehornblende dacite, as large as $35 \mathrm{~cm}$ but mostly mostly less than $4 \mathrm{~cm}$ in diameter, in gray ash matrix

Thickness (meters)

6. Very fine ash, pinkish-gray

5. Pyroclastic-flow deposit: unsorted mixture of angular and subangular fragments of hornblendehypersthene dacite in fine to coarse ash matrix; contains a few pumice lapilli and charcoal fragments that have a radiocarbon age of $11,550 \pm 230$ years $(W-2870)$ 
Deposits of Swift Creek age-Continued

Thickness (meters)

4. Tephra of set S: chiefly pumiceous ash and lapilli but also contains some lithic fragments; charcoal from soil zone at top yielded radiocarbon date of $11,900 \pm 190$ years $(W-2866)$

Deposit of undetermined age:

3. Colluvium: mixture of pumiceous ash and lapilli and small lithic fragments in fine ash matrix; yellowish brown. Thickness estimated

Deposit of Ape Canyon age:

2. Tephra of set $\mathrm{C}$ : mostly planar-bedded lithic ash and lapilli, interbedded with a few layers of pumiceous ash and lapilli $70-80 \mathrm{~cm}$ above base; light gray. Thickness approximate

Hayden Creek(?) Drift:

1. Till: mixture of rock fragments in very compact silt and sand matrix; dark gray, oxidized to brown (10YR 4/3) in upper $75-100 \mathrm{~cm}$ (buried soil); some cobbles and boulders striated and faceted, all of rock types found in local bedrock of Tertiary age $>4.0$

The unusual height of these deposits above the canyon floor may have resulted from pyroclastic flows that had sufficient velocity to run up opposite sides as they followed sinuous courses down the canyon. If it is assumed that the pyroclastic flows were moving along the canyon floor, a velocity of at least $44 \mathrm{~m} / \mathrm{s}(158 \mathrm{~km} / \mathrm{h})$ would have been necessary for them to have run up the canyon wall to a height of $100 \mathrm{~m}$ (p. 5).

A more likely explanation is that the deposits were emplaced by highly inflated, surgelike flows that momentarily filled the canyon to a depth of at least $100 \mathrm{~m}$ while they were moving. These flows were so mobile that they continued down the canyon, leaving veneers of material high on the valley walls.

Macdonald and Alcaraz (1956, p. 171) examined the distribution of pyroclastic-flow deposits formed during eruptions of Hibok-Hibok volcano in the Philippines in 1951. There, the walls of a valley on the north slope of the volcano were scoured, and remnants of pyroclasticflow deposits were left $50 \mathrm{~m}$ higher than the principal "permanent" deposit in the valley bottom. Macdonald and Alcaraz suggested that the height difference was due to compaction of the pyroclastic flow after it came to rest and lost its gas, and perhaps also to a decrease in the thickness of the flow after its crest moved downvalley.

The height of pyroclastic-flow deposits on the sides of Ape Canyon may have been indirectly caused by a precipitous scarp at the head of the canyon (fig. 6). The top of the scarp is only $1 \mathrm{~km}$ from the present base of the volcano. Pyroclastic flows descending $500 \mathrm{~m}$ in a distance of about $1.3 \mathrm{~km}$ across this scarp probably became highly turbulent and may have expanded greatly as they mixed with and heated large volumes of air. The relatively diffuse and highly mobile pyroclastic flows could then have left veneers on the canyon walls as they moved down the canyon.

\section{SOUTHEAST SIDE OF THE VOLCANO}

Few deposits of Swift Creek age are exposed in the upper part of the Pine Creek valley, probably because of burial by younger deposits. A pre-J deposit crops out in a cut along Forest Road 83 northeast of the Muddy River (locality 23). It is about $60 \mathrm{~cm}$ thick and contains rock fragments as large as $7 \mathrm{~cm}$ in diameter in a massive gray lithic ash matrix. Although some fragments in the deposit are as much as $7 \mathrm{~cm}$ in maximum diameter, most are less than $1 \mathrm{~cm}$. The overall fine texture of the deposit suggests that it was formed by an ash cloud or pyroclastic surge. Interbedded layers of fine ash and small lapilli beneath it may have been formed by a pyroclastic surge.

Floods and lahars caused by the May 18, 1980, eruption stripped vegetation from broad areas along the Muddy River and created many new outcrops, one of which is along the northeast bank of the Muddy River near Forest Road 83 (locality 24). Three deposits occur there between tephra sets $S$ and J. The lowest unit consists of lithic fine ash about $50 \mathrm{~cm}$ thick, probably the deposit of an ash cloud or pyroclastic surge. Above it is a deposit of angular fragments of nonvesicular dacite, mostly less than $1 \mathrm{~cm}$ in diameter but as large as $7 \mathrm{~cm}$ in diameter, in an ash matrix. The deposit is lenticular, and the maximum observed thickness was $50 \mathrm{~cm}$. It was formed by either a pyroclastic surge or a pyroclastic flow. It is overlain by a pyroclastic-flow deposit that contains blocks of lithic dacite as large as $30 \mathrm{~cm}$ in diameter. This deposit also is lenticular and locally is $2.5 \mathrm{~m}$ thick. It may be correlative with a similar pyroclastic-flow deposit that is exposed at a quarry near the confluence of Smith Creek and the Muddy River (locality 19).

The pyroclastic-flow deposit at the quarry outcrop is $30-50 \mathrm{~cm}$ thick and consists of angular fragments of nonvesicular dacite as large as $15 \times 35 \times 40 \mathrm{~cm}$ in a lithic ash matrix. The deposit occurs at a height of about $30 \mathrm{~m}$ above the valley floor and probably reached this height because of the speed of the pyroclastic flow. Such a height suggests a minimum velocity of $24 \mathrm{~m} / \mathrm{s}(87 \mathrm{~km} / \mathrm{h})$. Roadcuts on the sides of the Muddy River valley in section 15 expose lenticular ash-cloud deposits as much as $15 \mathrm{~cm}$ thick between tephra sets $S$ and J. Similar deposits in the same stratigraphic position also crop out in cuts along Forest Road 83 southwest of Bear Lake.

During the post-S part of the Swift Creek eruptive stage, lahars and pyroclastic flows of nonvesicular dacite moving down the Pine Creek valley built a fan across the Muddy River valley at Cedar Flats. The fan deposits are more than $50 \mathrm{~m}$ thick and underlie an area about $1.5 \mathrm{~km}$ wide and $5 \mathrm{~km}$ long. This fan temporarily dammed the Lewis River and at least one lahar extended $8 \mathrm{~km}$ upstream along the Lewis River valley from the 


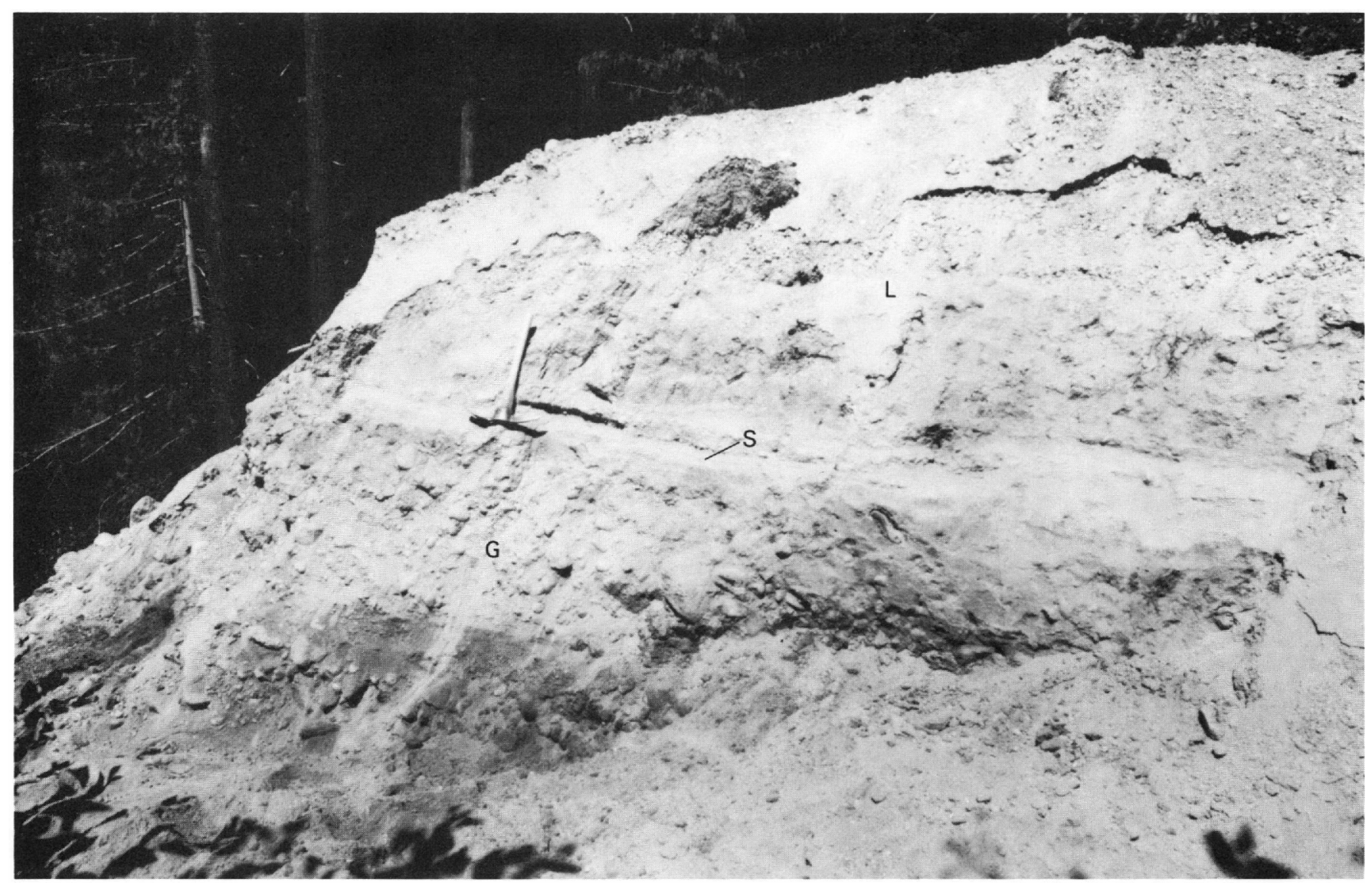

FIgure 18.-Lahar (L) of Swift Creek age overlying tephra of set S (S) and outwash sand and gravel (G) of Fraser age in the Lewis River valley at locality 29 . The deposits form a terrace that is about $43 \mathrm{~m}$ above the Lewis River.

mouth of the Muddy River (Crandell and Mullineaux, 1973) (locality 29) (fig. 18). The sequence of lahars and one pyroclastic-flow deposit is well exposed along a logging road near the mouth of the Muddy River (locality 32) (measured section 4). Soon after the fan was formed, it was eroded by the Muddy River, and a lahar subsequently moved down the resulting trench. Wood from the deposit of this lahar yielded a radiocarbon date of $11,800 \pm 90$ years ( $W-2655$ ).

\section{Measured section 4}

[Location-cuts along logging road in west valley wall of Muddy River at locality 32 in the NW1/4SE1/4 sec. 24, T. 7 N., R. 6 E.]

Deposits of Smith Creek and younger ages:

Thickness (meters)

17. Tephra of set $\mathrm{Y}$ and younger tephra

16. Lahar: unsorted and unstratified mixture of .3 subangular and subrounded rock fragments as much as $15 \mathrm{~cm}$ in diameter in sand matrix; fragments consist of hypersthene-hornblende dacite and hornblende dacite, some containing a trace of augite
Deposits of Swift Creek age:

15. Tephra of set $\mathbf{J}$

14. Lahar: unsorted mixture of subangular and subrounded rock fragments as much as $1 \mathrm{~m}$ in diameter in very compact matrix of gray silt and sand; fragments consist of hypersthene-hornblendeaugite dacite and hornblende-hypersthene dacite; clasts have random directions of TRM (K. S. Kellogg, written commun., 1975)

13. Lahar: unsorted mixture of subangular and subrounded rock fragments in matrix of brownishgray sand and granules; fragments consist of hypersthene-hornblende dacite and hypersthenehornblende-augite dacite; clasts have random directions of TRM; zone 10-15 cm thick at base has fewer clasts than rest of lahar

12. Lahar: unsorted mixture of angular to subrounded dacite fragments in matrix of brownish-gray sand and granules; grades upward into wellsorted medium sand at top; separated from overlying unit by silt parting about $1 \mathrm{~cm}$ thick; most clasts less than $3 \mathrm{~cm}$ in diameter; some of a slightly vesicular light-gray rock as much as 20 $\mathrm{cm}$ in diameter

Thickness (meters)

.3 
Deposits of Swift Creek age-Continued

11. Lahar: unsorted mixture of rock fragments as much as $7 \mathrm{~cm}$ in diameter in brownish-gray sand matrix; fragments consist of hypersthene-hornblende dacite, some also containing augite; some fragments resemble segments of prismatically jointed blocks

10. Lahar: unsorted mixture of subangular and subrounded rock fragments as much as $75 \mathrm{~cm}$ in diameter in gray sand matrix, contains some lenses of openwork gravel; overlies westward sloping erosional unconformity. As much as . .

9. Pyroclastic-flow deposit: unsorted mixture of subangular and subrounded rock fragments as much as $1 \mathrm{~m}$ in diameter in very compact fine ash matrix, gray with faint purplish cast; contains irregular masses of reddish-gray material; rock fragments consist of hypersthene-hornblende dacite containing a trace of augite; clasts have a preferred direction of TRM and thus evidently were hot when deposited

8. Silt and very fine sand

7. Lahar: unsorted mixture of subangular and subrounded dacite fragments in compact matrix of pinkish-gray sand

6. Lahar: unsorted mixture of subangular and subrounded dacite fragments as large as $20 \mathrm{~cm}$ in diameter in compact matrix of gray sand ...

5. Lahar: unsorted mixture of subangular and subrounded rock fragments as much as $30 \mathrm{~cm}$ in diameter in compact matrix of purplish-gray sand; some fragments consist of hornblende dacite, others of hypersthene-hornblende dacite containing small amounts of augite; lahar contains scattered lapilli of cummingtonite-hornblende pumice

4. Silt and very fine sand, pinkish-gray and yellowishgray; contains scattered lapilli of cummingtonitehornblende pumice

3. Lahar: unsorted mixture of subangular rock fragments as much as $20 \mathrm{~cm}$ in diameter in very compact matrix of gray silty sand; fragments consist of hornblende dacite and hypersthene-hornblende dacite containing small amounts of augite; lahar also contains scattered lapilli of cummingtonitehornblende pumice

2. Openwork gravel of angular and subangular lapilli of cummingtonite-hormblende pumice and scattered lapilli of nonvesicular hypersthenehornblende dacite; lenticular. As much as

1. Lahar: unsorted mixture of subangular and subrounded rock fragments as much as $15 \mathrm{~cm}$ in diameter in compact matrix of yellowish-gray sand; fragments consist of hypersthenehornblende dacite containing a small amount of augite, and scattered lapilli of cummingtonitehormblende pumice; grades upward to silt and fine sand at top

\section{NATURE AND AGE OF VOLCANISM}

The Swift Creek eruptive stage began about 13,000 years ago when explosive eruptions produced pumiceous tephra as well as lithic and pumiceous pyroclastic a change occurred after Pine Creek time. A new eruptive style that began with the Castle Creek eruptive period, in which dacite eruptions alternated with those of more mafic rock types, has characterized most of the subsequent history of Mount St. Helens.

\section{SMITH CREEK ERUPTIVE PERIOD}

\section{DEPOSITS}

The Smith Creek eruptive period probably began about 4,000 radiocarbon years ago (table 6) and ended an apparently dormant interval at the volcano that had 
TABLE 6.-Radiocarbon dates on samples that date or limit the ages of deposits of the Smith Creek eruptive period

[Corrected dates are based on the treering correction curve of Pearson and Stuiver (1986). Dates are in years before 1950. A onesigma standard deviation is not shown for the corrected dates.]

\begin{tabular}{|c|c|c|c|}
\hline $\begin{array}{c}\text { Radiocarbon } \\
\text { date }\end{array}$ & $\begin{array}{l}\text { Corrected } \\
\text { date }\end{array}$ & $\begin{array}{c}\text { Sample } \\
\text { No. }\end{array}$ & Stratigraphic position and location \\
\hline $2,900 \pm 70$ & $\begin{array}{c}3,020 \text { or } \\
3,040\end{array}$ & $w-2875$ & $\begin{array}{l}\text { Carbonized wood in soil proftle above } \\
\text { lahar of Smith Creek age. Cravel } \\
\text { pit near mouth of Alder Creek, North } \\
\text { Fork Toutle River valley, SWl/4 } \\
\text { sec. } 15, \text { T. } 10 \text { N., R. } 2 \text { E. }\end{array}$ \\
\hline $2,930 \pm 60$ & $\begin{array}{c}3,080 \text { or } \\
3,100\end{array}$ & $W-2829$ & $\begin{array}{l}\text { Wood from base of tephra set P. Smith } \\
\text { Creek valley, NEl/4 sec. 9, T. } 8 \mathrm{~N} \text {, } \\
\text { R. } 6 \mathrm{E} \text {. }\end{array}$ \\
\hline $2,960 \pm 50$ & $\begin{array}{c}3,120,3,165 \\
\text { or } 3,200\end{array}$ & $W-2675$ & Same as sample $\mathrm{W}-2829$ \\
\hline $1_{3,280 \pm 90}$ & $\begin{array}{c}3,480,3,520 \\
\text { or } 3,540\end{array}$ & $W-3262$ & $\begin{array}{l}\text { Charred wood in deposit of hot lahar } \\
\text { 1nterbedded with layers of tephra set } \\
\text { Y. Cut along Forest Road } 921 \text { n } \\
\text { NE } 1 / 4 \text { sec. } 30, \text { T. } 9 \text { N., R. } 6 \text { E. }\end{array}$ \\
\hline $1_{3,350 \pm 50}$ & 3,625 & $W-2549$ & $\begin{array}{l}\text { Charcoal from ash-cloud deposit above } \\
\text { tephra layer Ye and beneath other } \\
\text { layers of set } \mathrm{Y} \text {. Cut along Forest Road } \\
92, \mathrm{SE} 1 / 4 \mathrm{NE} 1 / 4 \mathrm{sec} .30, \mathrm{~T} .9 \mathrm{~N} \text {, } \\
\text { R. } 6 \mathrm{E} \text {. }\end{array}$ \\
\hline $1_{3,380 \pm 60}$ & 3,640 & $W-3144$ & $\begin{array}{l}\text { Charcoal from lithic pyroclastic-flow } \\
\text { deposit interbedded with upper layers } \\
\text { of tephra set } Y \text {. Same location as } \\
W-3262 \text {. }\end{array}$ \\
\hline $3,510 \pm 80$ & $\begin{array}{c}3,780 \text { or } \\
3,830\end{array}$ & $W-1752$ & $\begin{array}{l}\text { Charcoal at base of tephra layer Yn. } \\
\text { Cut along Forest Road } 99, \mathrm{NE} 1 / 4 \\
\text { sec. } 24, \text { T. } 9 \text { N., R. } 5 \text { E. }\end{array}$ \\
\hline $3,850 \pm 70$ & 4,285 & $W-3911$ & $\begin{array}{l}\text { Charcoal from base of tephra set } Y \text {. } \\
\text { Cut along Forest Road } 115, \text { SEl } / 4 \\
\text { sec. } 9 \text {, T. } 10 \text { N., R. } 6 \text { E. }\end{array}$ \\
\hline $3,900 \pm 50$ & 4,410 & $W-2677$ & $\begin{array}{l}\text { Charcoal from base of tephra set } \mathrm{Y} \text {. } \\
\text { Cut along Forest Road } 92 \text { in Smith } \\
\text { Creek valley, NWl/4 sec. } 9 \text {, T. } 8 \text { N., } \\
\text { R. } 6 \text { E. }\end{array}$ \\
\hline
\end{tabular}

${ }^{1}$ Date on deposit that resulted from an eruption. 
lasted more than 5,000 years. The eruptive period is named for the valley of Smith Creek northeast of the volcano, where pyroclastic-flow deposits and lahars are interbedded with tephra of set $\mathrm{Y}$. These deposits are discussed below, followed by a description of deposits of Smith Creek age elsewhere around the volcano.

\section{EAST SIDE OF THE VOLCANO}

Before the 1980 eruptions, a succession of flowage deposits interbedded with tephra of set $Y$ cropped out in a cut along Forest Road 92 and in an adjacent streambank downslope from the road (locality 10) (measured section 5). The lowest unit in the streambank was a mudflow whose base was below Smith Creek. It contained boulders as much as $2 \mathrm{~m}$ in diameter derived from the local bedrock; the mudflow may not have been related in any way to Mount St. Helens.

\section{Measured section 5}

[Location-roadcut along Forest Road 92 and adjacent bank of Smith Creek at locality 10 in the SW1/4SE1/4 sec. 30 , T. 9 N., R. 6 E.]

10. Tephra of set $\mathrm{Y}$ and younger sets

9. Pyroclastic-flow deposit or lahar: lapilli of cummingtonite-hornblende pumice and light-gray dacite in ash matrix; mottled purplish gray and light yellowish brown; contains scattered angular fragments of bedrock; lenticular. As much as

8. Pyroclastic-flow deposit: angular and subangular fragments of light-gray and reddish-gray hornblende-cummingtonite dacite, mostly less than $5 \mathrm{~cm}$ in diameter, but as much as $20 \mathrm{~cm}$ in diameter, in loose matrix of dark-gray lithic ash; massive; clasts in lower $60 \mathrm{~cm}$ are mostly less than $1 \mathrm{~cm}$ in diameter; contains charcoal logs that have a radiocarbon age of $3,380 \pm 60$ years $(W-3144)$ as well as scattered pumice lapilli

7. Tephra of set $Y$ : pumiceous ash and lapilli

6. Lahar: clasts mostly less than $10 \mathrm{~cm}$ in diameter of cummingtonite-hornblende pumice and nonvesicular cummingtonite-hornblende dacite in semicompact sand matrix; some pumice blocks breadcrusted and most dacite blocks prismatically jointed; contains both charred and uncharred wood, which has a radiocarbon age of $3,280 \pm 90$ years (W-3262), as well as abundant fragments of tree bark

5. Tephra of set $Y$ : pumiceous ash and lapilli; lower part stained by yellowish-brown iron oxides

4. Sand, fine; contains wood fragments

3. Sand, fine, brownish gray

2. Sand and gravel consisting chiefly of pumice lapilli interbedded with fine sand; lenticular layer of pebbles and cobbles of nonvesicular rock at top; stained with iron oxides

Erosional unconformity

1. Mudflow: heterolithologic; contains boulders as much as $2 \mathrm{~m}$ in diameter; extends below Smith Creek
The thick lahar in the outcrop (unit 6, measured section 5) (fig. 19) included clasts of both pumice and nonvesicular dacite in a matrix of sand and granules. The clasts occurred in about equal proportions and contained cummingtonite and hornblende. The deposit contained abundant wood fragments, some of which were charred. Progressive thermal demagnetization suggests that one clast in the deposit was emplaced at a temperature between $300^{\circ}$ and $400^{\circ} \mathrm{C}$, and another between $200^{\circ}$ and $400^{\circ} \mathrm{C}$ (R. P. Hoblitt, oral commun., 1979). Three other clasts were below the Curie temperatures of their constituent ferromagnetic minerals, which are probably between $500^{\circ}$ and $600^{\circ} \mathrm{C}$, but these data do not permit emplacement temperatures to be estimated. The paleomagnetic data, as well as the presence of both charred and uncharred wood, are consistent with the interpretation that the deposit was formed by a hot lahar.

An interesting feature of the lahar was the presence of fragments of tree bark. These probably were incorporated several kilometers upvalley, where the valley floor precipitously descends about $440 \mathrm{~m}$ in a distance of about $1 \mathrm{~km}$. The lahar must have been moving at high speed in this segment of the valley and carrying rock fragments that battered and stripped bark from tree trunks. Deposits of the lahar were not seen farther downvalley and may have been removed by stream erosion soon after they were formed.

A notable feature at the top of the lahar was the presence of vertical channels or "pipes" of material from which the sand-sized component of the matrix had been removed to produce an openwork texture (fig. 20). These ranged in width from about a centimeter to $6 \mathrm{~cm}$ and in length from $10 \mathrm{~cm}$ to $1 \mathrm{~m}$. Twenty of these openwork "pipes" were noted in a lateral distance of $3 \mathrm{~m}$. Granules and small pebbles in the "pipes" typically were coated with yellowish-brown iron oxides. It is inferred that after the lahar came to rest, the "pipes" were formed by the upward expulsion of water or steam, or both, which removed the fine components of the matrix. The "pipes" at the top of the lahar did not seem to be genetically related to charcoal in the deposit.

The pyroclastic-flow deposit (unit 8, measured section 5) above the lahar consisted mostly of clasts of nonvesicular cummingtonite-hornblende dacite in a loose ash matrix. This rock debris probably was derived from the disruption of a dome as it was being extruded. A chemical analysis of a prismatically jointed block from this deposit showed a $\mathrm{SiO}_{2}$ content of 64.6 percent (sample 6, app. A).

Vertical "pipes" of openwork texture extended upward from charcoal logs in this deposit. Rock fragments in these "pipes" were coated with a black film, probably an organic compound distilled from the logs as they 


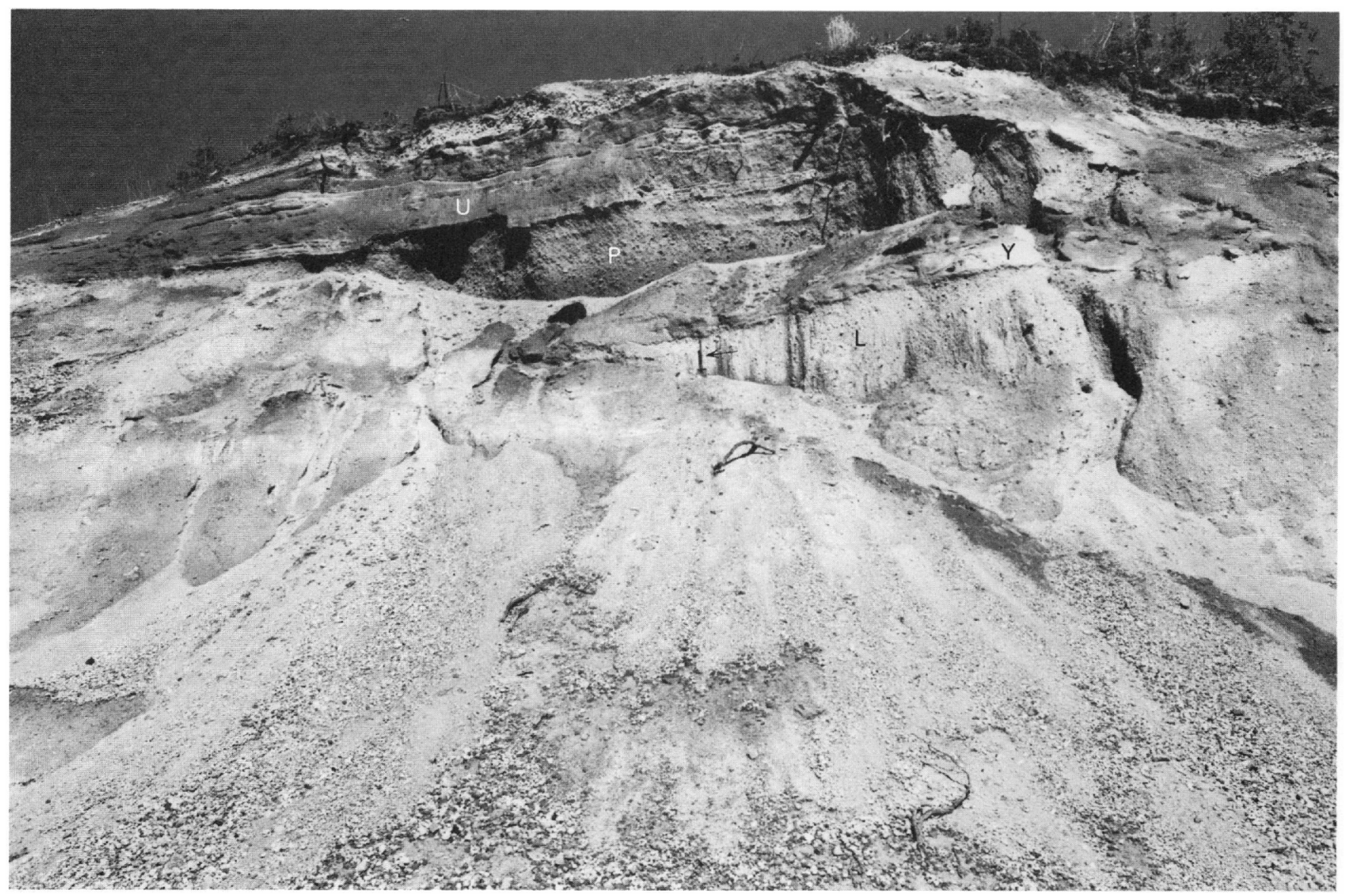

Figure 19.-Deposits of a pyroclastic-flow (P) and a hot lahar (L) of Smith Creek age in the Smith Creek valley at locality 10. Tephra layers of set $\mathrm{Y}(\mathrm{Y})$ both overlie and underlie the pyroclastic-flow deposit; younger tephra units (U) form the stratified deposits at the top of the outcrop. Scale is indicated by shovel $70 \mathrm{~cm}$ long (arrow). Photograph taken in 1978.

were being cooked in the hot deposit. The matrix of the pyroclastic-flow deposit within half a meter of a charcoal log also was darker than other parts of the matrix; this darker "halo" also is thought to have resulted from the deposition of organic compounds derived from the $\log$.

Ash-cloud deposits are interbedded with tephra of set $Y$ on the sides of the Smith Creek valley. At a cut along Forest Road 92 (locality 8), an ash-cloud deposit that is younger than layer Ye of tephra set $Y$ is about $20 \mathrm{~cm}$ thick (D. R. Mullineaux, oral commun., 1977). This locality is about $125 \mathrm{~m}$ higher than the pyroclastic-flow deposit just described and about $0.8 \mathrm{~km}$ to the northnortheast. Charcoal in the ash-cloud deposit yielded a radiocarbon date of $3,350 \pm 50$ years ( $W-2549$; Mullineaux and others, 1975). In a roadcut on the ridge top $1.5 \mathrm{~km}$ to the northeast (locality 9), an ash-cloud deposit as much as $15 \mathrm{~cm}$ thick and in the same stratigraphic position occurs at a height of about $500 \mathrm{~m}$ above the Smith Creek valley floor.
A charcoal-bearing pyroclastic-flow deposit of Smith Creek age crops out at several places along a logging road on the south side of Ape Canyon nearly $100 \mathrm{~m}$ above the canyon floor. The emplacement of similar deposits so high on the canyon wall was discussed previously (p. 34). The deposit is as much as $1.8 \mathrm{~m}$ thick and consists of breadcrusted blocks of cummingtonite-hornblende pumice and nonvesicular dacite in a loose ash matrix. It directly overlies tephra set $\mathrm{J}$ and may be older than any of the Smith Creek deposits described in measured section 5 . The pyroclastic-flow deposit is locally overlain by about $1 \mathrm{~m}$ of pumiceous and lithic ash that may be an ash-cloud deposit, above which is tephra of set $\mathrm{Y}$.

Farther south, along the east side of the Muddy River where the river is crossed by Forest Road 83 (locality 24), a lithic and pumiceous pyroclastic-surge deposit of Smith Creek age is interbedded with layers of tephra set Y (fig. 21). The lenticular surge deposit is as much as about a meter thick and consists mostly of planar 


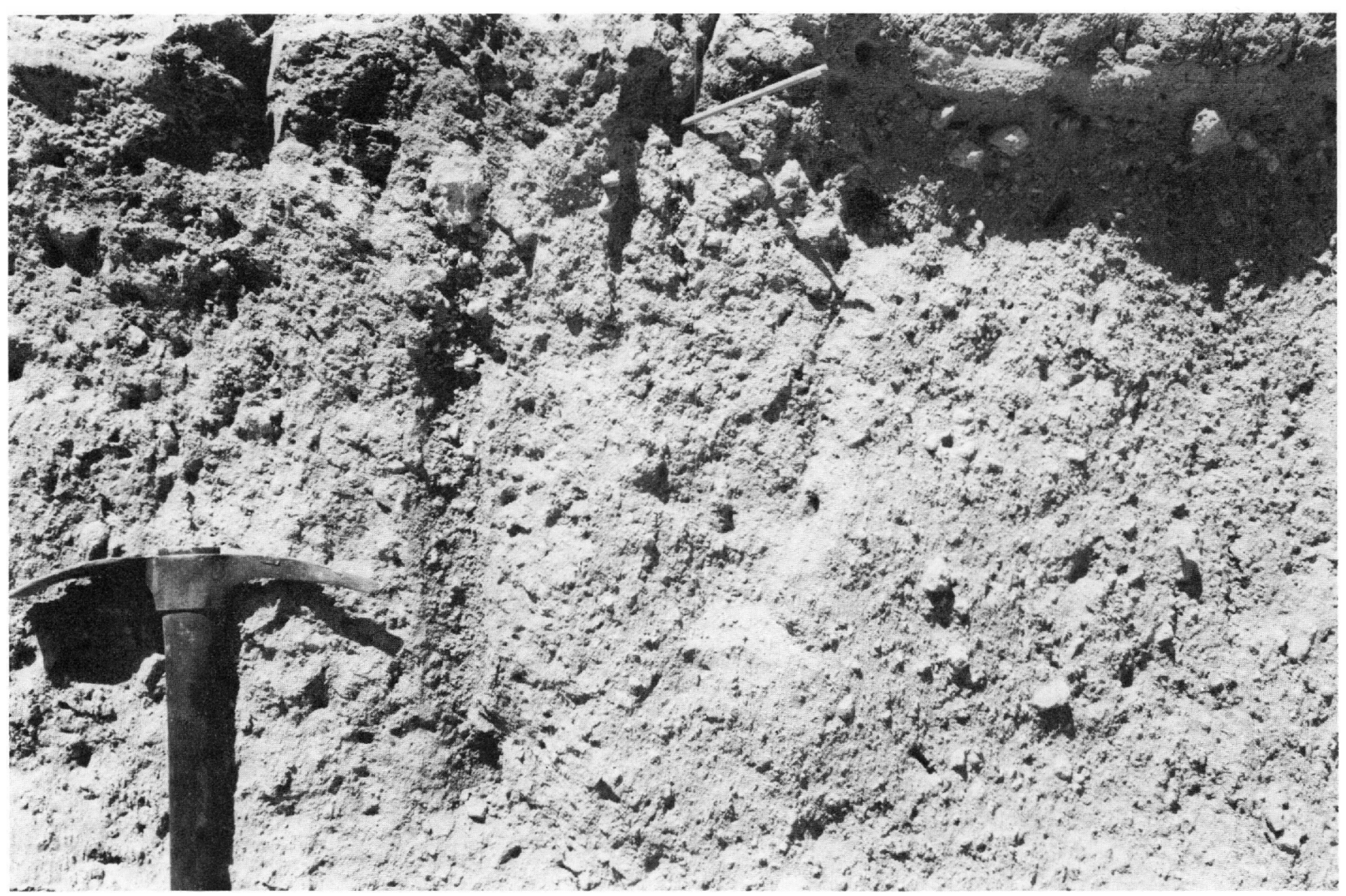

FIgURE 20.-Vertical "pipes" of openwork material at the top of a deposit of a hot lahar of Smith Creek age shown in figure 19 (locality 10). One "pipe" is to the right of the pick and another is near the top of the lahar below point of pencil.

and crossbedded ash at the base which coarsens upward into lapilli and small blocks.

\section{NORTH SIDE OF THE VOLCANO}

During Smith Creek time the North Fork Toutle River valley west of Spirit Lake was partly filled by lahars and pyroclastic flows that descended the north slope of the volcano. Before the 1980 eruptions, remnants of the valley fill cropped out in roadcuts west of Spirit Lake Lodge; in 1974 they were especially well exposed in a landslide scar about $1 \mathrm{~km}$ west of the lodge. A series of lahars could be seen there in contact with the bedrock that forms the steeply sloping valley wall. A lithic pyroclastic-flow deposit near the top of the sequence was capped by reddish-gray fine ash about $0.5 \mathrm{~m}$ thick. The ash contained charcoal fragments and probably was the deposit of an ash cloud associated with a pyroclastic flow. The ash was overlain by about $1 \mathrm{~m}$ of coarse pumice lapilli of tephra layer Yn. The deposits formed a narrow terrace which was nearly $40 \mathrm{~m}$ above the North Fork Toutle River and which was only slightly lower than the pre-1980 level of Spirit Lake; thus, the deposits represented a fill that probably blocked the North Fork valley and impounded a lake.

Farther downvalley, lahars of probable Smith Creek age can be seen beneath those of Pine Creek age in exposures at Alder Creek, $30 \mathrm{~km}$ from the volcano, and near Toutle Lake (Gilmore Corners) (locality 77), $50 \mathrm{~km}$ from the volcano (p. 51). The lahar at Alder Creek is exposed in a gravel pit on the south side of the North Fork Toutle River valley (locality 81 ), where it is overlain by a soil containing wood fragments that have a radiocarbon age of $2,900 \pm 70$ years (W-2875). Wood from a similar soil in the outcrop near Toutle Lake was dated as $2,810 \pm 70$ years old (W-3265).

K. M. Scott (written commun., 1984) suggested that the deposits at Alder Creek and near Toutle Lake represent the same lahar and are correlative with similar deposits he observed down the Toutle River nearly to its mouth. The extent and thickness of the deposits 


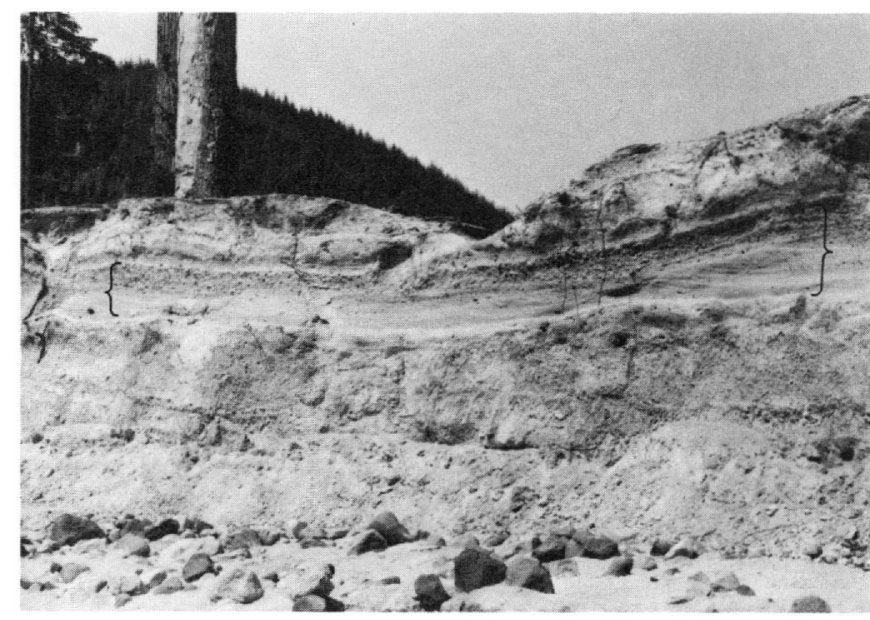

FIGURE 21.-Pyroclastic-surge deposit (brackets) of Smith Creek age interbedded with layers of tephra set $Y$ on east side of Muddy River at Forest Road 83. Pyroclastic-surge deposit is about $1 \mathrm{~m}$ thick. Photograph taken in July 1982.

suggested to Scott that the lahar reached downstream to the Columbia River.

\section{NATURE AND AGE OF VOLCANISM}

Large-volume eruptions of pumice occurred several times during the Smith Creek eruptive period. Tephra set $Y$, which was formed during this time, consists of at least a dozen discrete pumice layers, some of which extend tens to hundreds of kilometers from the volcano (Mullineaux and others, 1975). The abundance of nonvesicular rock fragments in pyroclastic-flow deposits and lahars of Smith Creek age suggests that dome extrusion alternated with explosive eruptions.

The volume of lahars and pyroclastic flows of Smith Creek age seems to be smaller than that of Swift Creek time and perhaps an order of magnitude smaller than that of Pine Creek time. The volume of pumiceous tephra erupted during Smith Creek time was greater than that of any other eruptive period of postglacial time; it may have been equaled only by that of the Ape Canyon eruptive period (D. R. Mullineaux, oral commun., 1978).

The oldest radiocarbon date from a deposit formed directly by an eruption during Smith Creek time is $3,380 \pm 60$ years ( $W-3144$ ); older dates were determined on samples taken from horizons immediately beneath tephra layers formed during the eruptive period.

Near Mount St. Helens, the youngest radiocarbon date from deposits beneath tephra set $Y, 3,850 \pm 70$ years, was reported on a sample immediately beneath tephra layer $\mathrm{Yb}$, the basal layer of the set (Mullineaux and others, 1975, p. 331; Crandell and others, 1981, p. 9).
Thus, dates from near the volcano seem to imply that the eruptive period began less than about 4,000 radiocarbon years ago.

The youngest date on a deposit of Smith Creek age is $3,280 \pm 90$ years ( $W-3262$ ), but this deposit underlies one on which a radiocarbon date of $3,380 \pm 60$ years (W-3144) was obtained. The data now available thus suggest that the eruptive period continued until some time after 3,400 radiocarbon years ago. The oldest radiocarbon date on a deposit formed during the ensuing Pine Creek eruptive period is $2,910 \pm 70$ years (W-2980).

When corrected for variations in atmospheric radiocarbon, the limiting date of 3,850 years represents a calendar date of about 4,285 years ago (table 6). The radiocarbon date of 3,280 represents a calendar age of between 3,540 and 3,480 years ago, and the radiocarbon date of 3,380 is corrected to 3,640 years ago. These corrected dates suggest that the Smith Creek eruptive period lasted a little more than 600 years.

\section{PINE CREEK ERUPTIVE PERIOD}

\section{DEPOSITS}

The Pine Creek eruptive period probably began about 3,000 radiocarbon years ago and ended about 2,500 years ago (table 7). Large pyroclastic flows of lithic dacite rock debris and pumice repeatedly moved outward from the volcano in most, if not all, directions during Pine Creek time; and lahars flowed many tens of kilometers down valleys that head at the volcano. Some of the resulting deposits were described in an earlier report (Crandell and Mullineaux, 1973) that introduced the informal term "Pine Creek volcanic assemblage." The assemblage included the deposits of what we now regard as three periods of volcanism that extended from about 13,000 to 2,500 years ago. Subsequent work has clarified details of the eruptive history of Mount St. Helens, and we now believe the deposits of the Pine Creek assemblage of our previous report to be products of the Swift Creek, Smith Creek, and Pine Creek eruptive periods, as shown below.

\begin{tabular}{|c|c|c|c|c|}
\hline $\begin{array}{c}\text { Eruptive } \\
\text { period }\end{array}$ & $\begin{array}{c}\text { Approximate } \\
\text { radiocarbon } \\
\text { age }\end{array}$ & Reference & $\begin{array}{l}\text { Flowage } \\
\text { deposits }\end{array}$ & $\begin{array}{l}\text { Correla- } \\
\text { tive } \\
\text { tephra } \\
\text { set }\end{array}$ \\
\hline Pine Creek & $3,000-2,500$ & $\begin{array}{l}\text { Pine Creek } \\
\text { assemblage of } \\
\text { Crandell and } \\
\text { Mullineaux } \\
\text { (1973). }\end{array}$ & $\begin{array}{l}\text { Pyroclastic } \\
\text { flows and } \\
\text { lahars. }\end{array}$ & $\mathbf{P}$ \\
\hline Smith Creek & $4,000-3,300$ & do & do & $\mathrm{Y}$ \\
\hline Swift Creek & $13,000-10,000$ & do & do & $J$ and $S$ \\
\hline
\end{tabular}


PRE-1980 PYROCLASTIC FLOWS AND LAHARS, MOUNT SAINT HELENS

TABLE 7.-Radiocarbon dates on samples that date or limit the ages of deposits of the Pine Creek eruptive period

[Corrected dates are based on the tree-ring correction curves of Stuiver and Pearson (1986) and Pearson and Stuiver (1986). Dates are in years before 1950. A one-sigma standard deviation is not shown for the corrected dates.]

\begin{tabular}{|c|c|c|c|}
\hline $\begin{array}{l}\text { Radiocarbon } \\
\text { date }\end{array}$ & $\begin{array}{l}\text { Corrected } \\
\text { date }\end{array}$ & $\begin{array}{l}\text { Sample } \\
\text { No. }\end{array}$ & Stratigraphic position and location \\
\hline $1_{2,450 \pm 90}$ & 2,480 & $w-3266$ & $\begin{array}{l}\text { Charcoal from stratigraphically highest } \\
\text { lithic pyroclastic-flow deposit at point } \\
\text { between two forks of Pine Creek, NEl/4 } \\
\text { SE } 1 / 4 \text { sec. } 9, \text { T. } 7 \text { N., R. } 6 \text { E. }\end{array}$ \\
\hline $1_{2,580 \pm 60}$ & 2,750 & W-2529 & $\begin{array}{l}\text { Charcoal from near top of a lithic pyro- } \\
\text { clastic-flow deposit. Cut along logging } \\
\text { road in NE1/4 sec. } 26 \text {, T. } 8 \text { N., R. } 5 \text { E. }\end{array}$ \\
\hline $1_{2,670 \pm 70}$ & 2,775 & $W-2451$ & $\begin{array}{l}\text { Charcoal from pumiceous pyroclastic-flow } \\
\text { deposit of Pine Creek age. Cut along } \\
\text { abandoned logging road on west side of } \\
\text { Pine Creek valley near center of NWl/4 } \\
\text { sec. } 9 \text {, T. } 7 \text { N., R. } 6 \text { E. }\end{array}$ \\
\hline $2,810 \pm 70$ & $\begin{array}{l}2,890,2,905 \\
\quad \text { or } 2,935\end{array}$ & $W-3265$ & $\begin{array}{l}\text { Charcoal from humified sand beneath lowest } \\
\text { Pine Creek lahar in streambank adjacent } \\
\text { to gravel pit at Toutle Lake (Gilmore } \\
\text { Corners), near center sec. } 30, \mathrm{~T}, 10 \mathrm{~N} \text {, } \\
\text { R. } 1 \mathrm{E} \text {. }\end{array}$ \\
\hline $1_{2,840 \pm 100}$ & 2,950 & W-2873 & $\begin{array}{l}\text { Charcoal from lithic pyroclastic-flow } \\
\text { deposit on west side of Castle Creek } \\
\text { valley, SEl/4NWl/4 sec. } 24, \text { T. } 9 \mathrm{~N} \text {, } \\
\text { R. } 4 \mathrm{E} \text {. }\end{array}$ \\
\hline $1_{2,850 \pm 60}$ & 2,960 & $W-2452$ & $\begin{array}{l}\text { Charcoal from lowest pumiceous pyroclastic- } \\
\text { flow deposit (unit } 3 \text {, measured section 6) } \\
\text { in east trench wall of Plne Creek. NE } 1 / 4 \\
\text { SE } 1 / 4 \text { sec. } 9, \text { T. } 7 \text { N., R. } 6 \text { E. }\end{array}$ \\
\hline $2,900 \pm 70$ & $\begin{array}{c}3,020 \text { or } \\
3,040\end{array}$ & $W-2875$ & $\begin{array}{l}\text { Carbonized wood in soll beneath Pine Creek } \\
\text { lahars exposed in walls of gravel pit near } \\
\text { mouth of Alder Creek, in valley of North } \\
\text { Fork Toutle River, SWl/4 sec. } 15 \text {, } \\
\text { T. } 10 \mathrm{~N} ., \text { R. } 2 \text { E. }\end{array}$ \\
\hline$I_{2,910 \pm 70}$ & 3,050 & $W-2980$ & $\begin{array}{l}\text { Charcoal from pumiceous pyroclastic-flow } \\
\text { deposit of Pine Creek age. Cut along } \\
\text { Forest Road } 8123 \text { in valley of Coldspring } \\
\text { Creek, SW } 1 / 4 \mathrm{SE} 1 / 4 \text { sec. } 12 \text {, T. } 8 \text { N., } \\
\text { R. } 4 \mathrm{E} \text {. }\end{array}$ \\
\hline $2,930 \pm 60$ & $\begin{array}{c}3,080 \text { or } \\
3,100\end{array}$ & $W-2829$ & $\begin{array}{l}\text { Wood from base of tephra set P. Smith } \\
\text { Creek valley, NW } 1 / 4 \mathrm{NW} 1 / 4 \mathrm{sec} \cdot 9, \mathrm{~T} \cdot 8 \mathrm{~N} \cdot \text {, } \\
\text { R. } 6 \mathrm{E} \text {. }\end{array}$ \\
\hline $2,960 \pm 50$ & $\begin{array}{l}3,120,3,165 \\
\text { or } 3,200\end{array}$ & $W-2675$ & $\begin{array}{l}\text { Same horizon and location as sample } \\
\qquad W-2829 \text {. }\end{array}$ \\
\hline
\end{tabular}

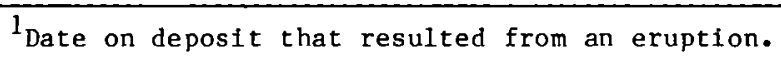




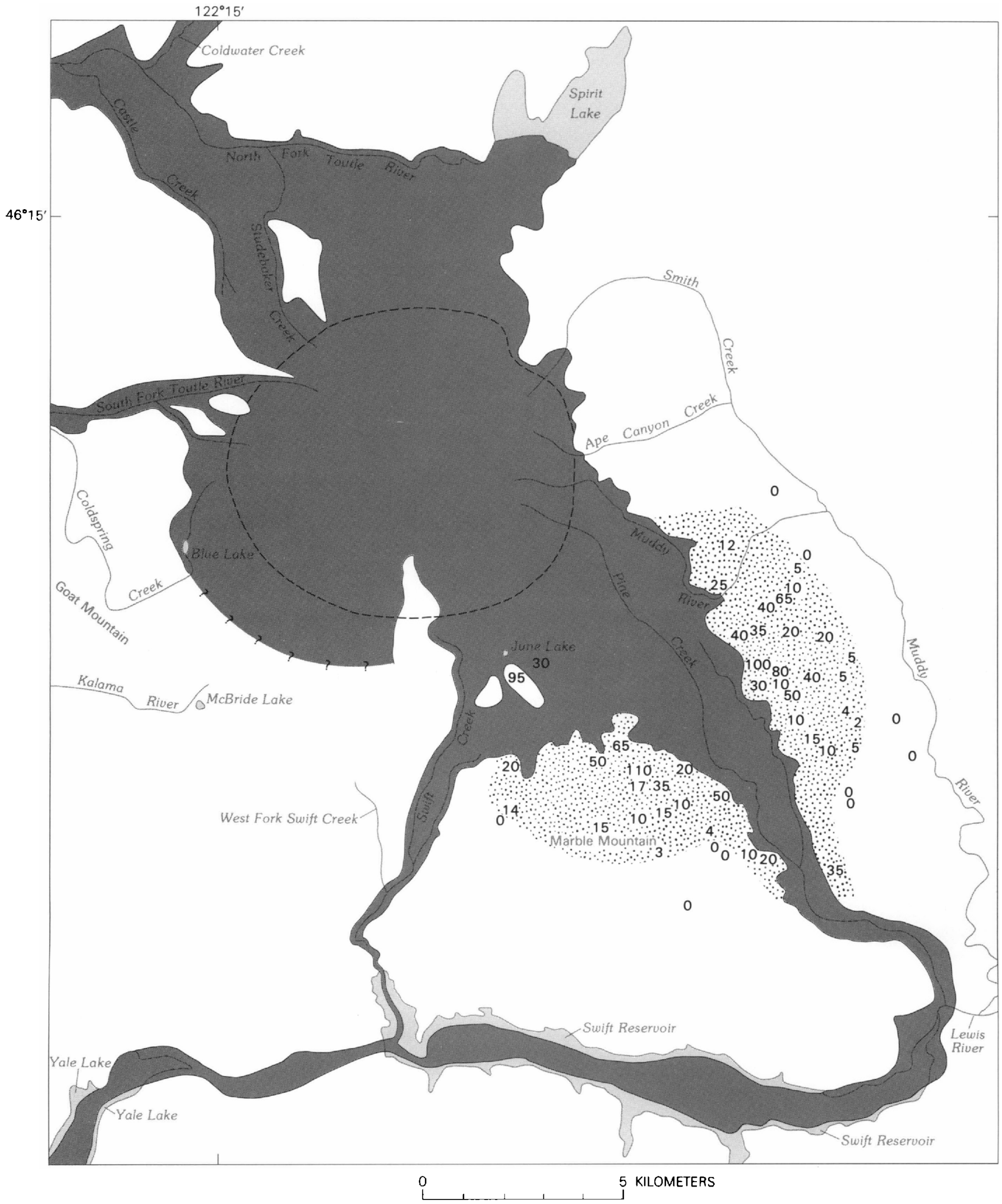

Figure 22.-Sketch map showing inferred original extent of pyroclastic-flow deposits, lahars, and alluvium formed during the Pine Creek eruptive period (solid pattern). Stippled pattern shows known areas of ash-cloud and pyroclastic-surge deposits; numbers show representative thicknesses in centimeters. Dashed line shows the base of the volcano. 
Deposits of Pine Creek age crop out at only a few places on the lower flanks of the volcano, but underlie broad areas immediately beyond the base of the volcano and form fill terraces in valleys at greater distances (fig. 22). These deposits are described here according to the valley system in which they are found, from the valley of Pine Creek clockwise around the volcano.

\section{PINE CREEK VALLEY}

Beyond the southeast base of the volcano, deposits of Pine Creek age form a broad south-sloping fan that is bounded on the east by the Muddy River and on the west by Swift Creek. Deposits that make up the fan are at least $125 \mathrm{~m}$ thick in places. Those exposed in the steep valley walls of Pine Creek consist mostly of pyroclastic-flow deposits at least as far southeastward as the E1/2 sec. 15, T. 7 N., R. 6 E. Farther downstream, the Pine Creek deposits form terraces in a valley cut into deposits of Swift Creek age. These terraces extend to the Lewis River valley, where they are now inundated by Swift Reservoir. A topographic map ${ }^{4}$ of the Lewis River valley surveyed in 1935 before the reservoir was created shows the terraces as far downstream as $5 \mathrm{~km}$ east of Swift Dam, where they evidently merged with the Lewis River flood plain. Deposits that underlie terraces along Pine Creek for a distance of $3 \mathrm{~km}$ upstream from the reservoir consist mainly of fluvial sand and gravel interbedded with lahars less than $1 \mathrm{~m}$ thick. These deposits probably were formed by fluvial reworking of pyroclastic flows soon after they came to rest upvalley.

Remnants of the valley fill of Pine Creek age were not recognized between Swift and Merwin Dams, but a terrace in the lower Lewis River valley near Woodland is underlain by gray, pumice-bearing sandy alluvium that evidently is the downstream correlative of the pyroclastic-flow deposits and lahars closer to the volcano (Crandell and Mullineaux, 1973). Pumice in the alluvium is mineralogically similar to that of other Pine Creek deposits, and the alluvium bears an immature soil that also is consistent with a Pine Creek age. The terrace is 7-8 $\mathrm{m}$ above the Lewis River and records a temporary aggradation of the river in response to large volumes of volcanic rock debris contributed to the drainage basin by eruptions at Mount St. Helens.

Within about $16 \mathrm{~km}$ from the base of the volcano, most of the deposits exposed along the Pine Creek valley seem to have been formed by pyroclastic flows. As many as 10 such deposits, from 1 to $12 \mathrm{~m}$ thick, can

\footnotetext{
${ }^{4}$ Plan and profile of Lewis River to mile 87 and tributaries, Washington (scale 1:31,680; contour interval $20 \mathrm{ft}$ on land) published by the U.S. Geological Survey in 1938.
}

be seen in a single outcrop (fig. 23). Some consist mainly or wholly of nonvesicular dacite fragments; others are mostly pumice (fig. 24). Pyroclastic-flow deposits composed of nonvesicular rock debris typically have a wider range of sizes and contain larger clasts (as much as $10 \mathrm{~m}$ in diameter) than do pumiceous pyroclastic-flow deposits, in which few clasts are larger than $30 \mathrm{~cm}$ in diameter. Both pumiceous and lithic pyroclastic-flow deposits commonly have reddish-gray zones $0.5-2 \mathrm{~m}$ thick at their tops; although both generally are very compact in outcrops, none are welded.

A chemical analysis of a prismatically jointed block from a lithic pyroclastic-flow deposit (unit 7, measured section 6) showed a $\mathrm{SiO}_{2}$ content of 64.2 percent (sample 7, app. A).

The most voluminous pyroclastic-flow deposits consist mostly or wholly of nonvesicular rock debris. One deposit that might have been formed by a single pyroclastic flow occurs at the top of the Pine Creek deposits over an area of at least $30 \mathrm{~km}^{2}$ at the southeast base of the volcano. It consists of large clasts of angular and subangular dacite in a lithic ash matrix and has a reddish-gray zone 1-3 m thick at the top. The deposit was observed to be $10-15 \mathrm{~m}$ thick at many outcrops; if the average thickness is $10 \mathrm{~m}$ for the area of $30 \mathrm{~km}^{2}$, the volume would be $0.3 \mathrm{~km}^{3}$. The similarity in overall aspect and stratigraphic position from one locality to another does not prove that the deposit was formed by a single pyroclastic flow, but this estimate probably represents a maximum volume for any pyroclastic flow of Pine Creek age.

Although intervals of fluvial erosion occurred during the accumulation of the Pine Creek deposits, none were necessarily of long duration. At measured section 6 (locality 33), a southeast-trending(?) channel at least $10 \mathrm{~m}$ deep that was cut into pyroclastic-flow deposits was subsequently filled with a succession of similar deposits. In the northeast wall of the Pine Creek trench farther upstream (locality 31 ), a south-trending channel at least $15 \mathrm{~m}$ deep was cut into a compact pumiceous pyroclastic-flow deposit and then filled with lenticular lahars 1-5 m thick chiefly of nonvesicular rock debris. A lithic pyroclastic-flow deposit, also of Pine Creek age, overlies these deposits; it is about $10 \mathrm{~m}$ thick and forms the present ground surface (fig. 25).

Measured section 6

[Location-east bank of Pine Creek at locality 33 in the NE1/4SE1/4 sec. 9. T. 7 N., R. 6 E. Temperature estimates provided by R. P. Hoblitt from progressive thermal demagnetization of clasts in the deposits]

Deposits of Pine Creek age:

Thickness (meters)

13. Pyroclastic-flow deposit: angular to subrounded lithic rock fragments and scattered pumice lapilli in gray ash matrix; compact and massive. Estimated 


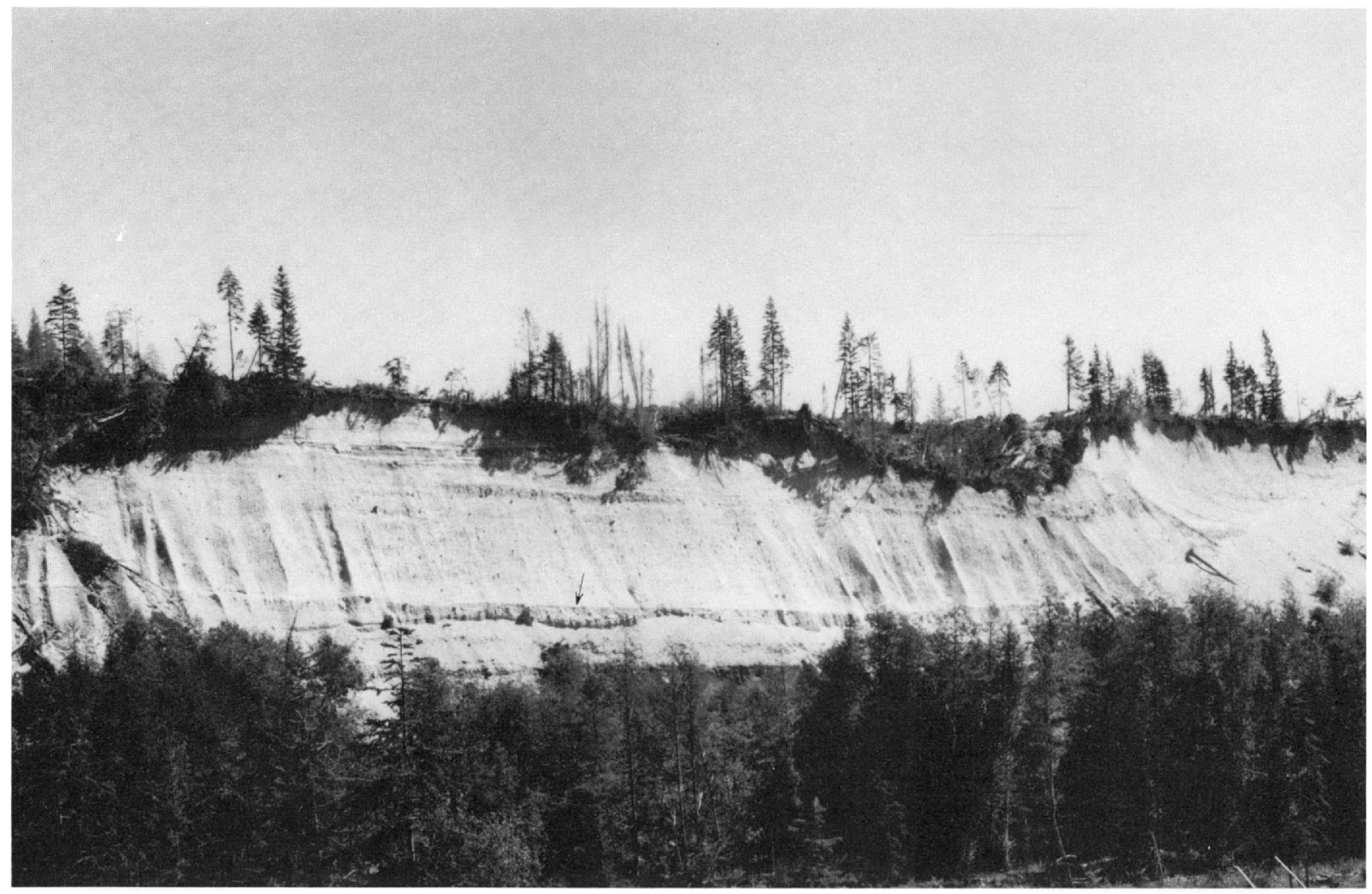

Figure 23.-Pyroclastic-flow deposits of Pine Creek age in east bank of Pine Creek $14.5 \mathrm{~km}$ southeast of the summit of Mount St. Helens (locality 33). Arrow points to a red-topped lithic pyroclastic-flow deposit (unit 7, measured section 6) that is $0.5-5 \mathrm{~m}$ thick.

Deposits of Pine Creek age-Continued

12. Pyroclastic-flow deposit: chiefly densely packed lapilli and small blocks of hypersthenehornblende pumice in fine ash matrix; blocks have preferred orientation of TRM, hence were probably emplaced at a temperature above $500^{\circ} \mathrm{C}$; compact, massive, and lenticular. As much as . ............

(Units 12 and 13 thicken southward, seem to merge, and fill a valley cut into older units; there they have an estimated combined thickness of about $20 \mathrm{~m}$ ).

11. Ash, planar bedded (inaccessible). Estimated .

10. Pyroclastic-flow deposit(?): chiefly rock fragments less than $5 \mathrm{~cm}$ in diameter in gray ash matrix; len. ticular (inaccessible). Estimated as much as .

9. Pyroclastic-flow deposit: chiefly angular to subangular lithic blocks in gray fine ash matrix; faint reddish-gray zone at top; includes poorly defined lenticular layers of pumice blocks; estimated emplacement temperature above $500^{\circ} \mathrm{C}$. Estimated.

8. Ash, gray, horizontally bedded; contains fragments of charcoal and pumice lapilli; lenticular. As much as

7. Pyroclastic-flow deposit: angular lithic blocks as much as $1.2 \mathrm{~m}$ in diameter in gray ash matrix; massive; reddish-gray in upper 1-1.5 m; contains abundant carcoal logs and local concentrations of
Deposits of Pine Creek age-Continued pumice blocks; estimated emplacement temperature above $500^{\circ} \mathrm{C}$

6. Ash, gray; horizontally bedded and locally crossbedded on small scale; most beds lenticular; locally contains charcoal fragments. As much as

5. Pyroclastic-flow deposit: angular and subangular lapilli of pumice and lithic dacite mostly less than $2 \mathrm{~cm}$ in diameter in gray ash matrix; locally contains a lens of pumice blocks as much as $\mathbf{4 0} \mathrm{cm}$ in diameter

4. Pyroclastic-flow deposit: blocks of pumice as much as $50 \mathrm{~cm}$ in diameter and angular lithic fragments less than $3 \mathrm{~cm}$ in diameter in white fine ash matrix; estimated emplacement temperature above $500^{\circ} \mathrm{C}$

3. Pyroclastic-flow deposit: blocks and lapilli of hypersthene-hormblende pumice, mostly less than $20 \mathrm{~cm}$ in diameter, and angular lithic lapilli in ash matrix; basal 30-40 cm lacks blocks; deposit contains abundant charcoal fragments and logs that have a radiocarbon age of $2,850 \pm 60$ years (W-2542)

2. Sand; locally oxidized; lenticular. As much as

1. Sand and cobble to boulder gravel; rock types chiefly andesite and dacite from Mount St. Helens
Thickness (meters) 


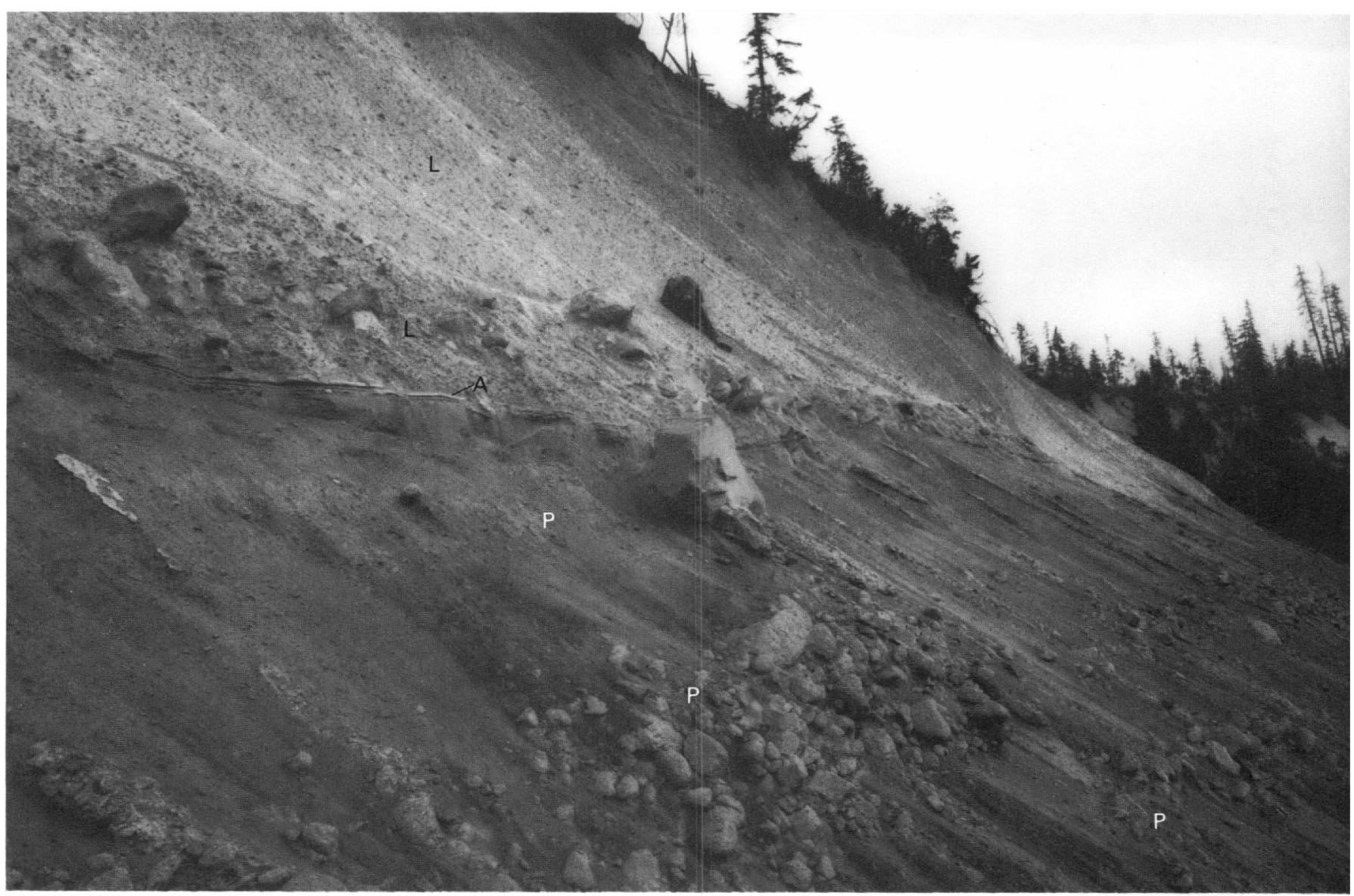

FIgure 24.-Two pyroclastic-flow deposits of lithic rock debris (L) overlying three pyroclastic-flow deposits (P) that consist of lapilli and blocks of pumice. Detail of the outcrop that is shown in figure 23. Thin beds of ash (A) overlie the pumiceous pyroclastic-flow deposits.

Hillsides adjacent to the valley fill of pyroclastic-flow deposits along Pine Creek are veneered with air-fall tephra; interbedded with tephra of set $P$ of Pine Creek age are layers of fine to very coarse lithic ash a few centimeters to a meter thick. Because of their proximity to the pyroclastic-flow deposits and their limited areal extent, most of the layers of lithic ash are believed to be fallout from clouds of fine material that were generated by and accompanied pyroclastic flows (Crandell and Mullineaux, 1973). The lithic ash deposits are typically massive, but locally are planar bedded and crossbedded (fig. 26). The crossbedded deposits probably were formed by pyroclastic surges, and some of the planar bedded and massive deposits may have had a similar origin. All these deposits commonly contain small angular lapilli of nonvesicular rock or pumice or both. The deposits extend up hillsides for hundreds of meters above the surface of adjacent pyroclastic-flow deposits, but are generally limited to a zone a few kilometers wide adjacent to those deposits. Lithic ash deposits within this zone generally decrease in grain size and thickness with increasing height and with distance from the margins of the pyroclastic-flow deposits.

The general distribution and representative thicknesses of ash-cloud deposits in the Pine Creek area were described by Crandell and Mullineaux (1973) and are shown in figure 22. These deposits generally become thinner away from their source, but they vary greatly in thickness within distances of only hundreds of meters. Such variations in thickness distinguish them from most air-fall tephra layers, which typically become gradually thinner over distances of many kilometers.

Ash-cloud deposits have been recognized at three horizons within tephra set $P$; the thickest and most widespread deposits are at the lower horizon, which is near the middle of the tephra set (Crandell and Mullineaux, 1973, p. 18). Ash-cloud deposits are rarely seen on top of or within successions of pyroclastic-flow deposits of Pine Creek age, but units 6 and 8 in measured section 6 probably were formed partly or wholly by ash clouds. Unit 6 is as thick as $15 \mathrm{~cm}$ and contains a bed that resembles a tephra layer of set $P$; this unit 


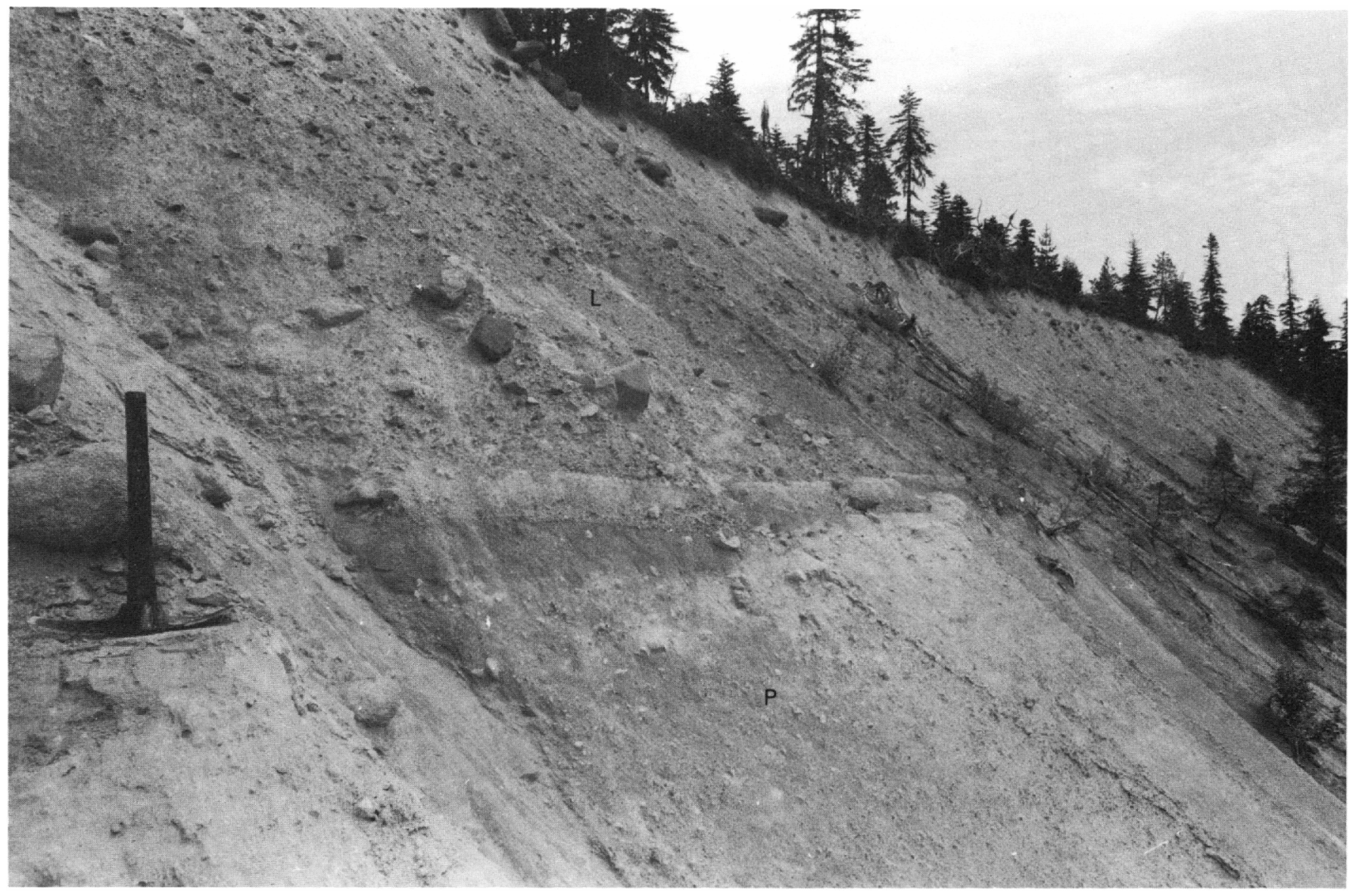

Figure 25.-Two pyroclastic-flow deposits of predominantly lithic (L) and pumiceous (P) rock debris in the bank of Pine Creek about $7 \mathrm{~km}$ southeast of the base of Mount St. Helens (locality 31).

is draped over undulations in the surface of the underlying pyroclastic-flow deposit and evidently was not disturbed during emplacement of the overlying pyroclastic flow (fig. 27). Crossbedded ash deposits, probably formed by one or more pyroclastic surges, are $50-80 \mathrm{~cm}$ thick at a roadcut exposure about $0.5 \mathrm{~km}$ northwest of measured section 6 , which is on the west side of the Pine Creek valley higher than the top of the pyroclastic-flow deposits. About $0.5 \mathrm{~km}$ east of the measured section, correlative ash deposits are massive and about $35 \mathrm{~cm}$ thick at a locality only a few hundred meters east and a few meters higher than the margin of the pyroclastic-flow deposits.

Closer to the volcano, at a locality about $0.9 \mathrm{~km}$ eastnortheast of June Lake, lithic pyroclastic-surge deposits $25-35 \mathrm{~cm}$ thick are exposed in a roadcut (locality 37) over a pyroclastic-flow deposit $50 \mathrm{~cm}$ thick. The surge deposits consist of very fine to coarse ash and very small lapilli; they are both horizontally bedded and foreset bedded. These deposits, which thicken to nearly a meter at a point about $0.7 \mathrm{~km}$ to the west, probably were formed by a pyroclastic surge moving southward from the volcano. In this area the deposits extend at least $200 \mathrm{~m}$ higher than the floor of the valley and are also present on top of a rock knob on the west side of the June Lake valley.

\section{VALLEYS OF COLDSPRING CREEK, KALAMA RIVER, AND SOUTH FORK TOUTLE RIVER}

Deposits of Pine Creek age crop out at only a few localities at the west base of the volcano. A pyroclasticflow deposit of hypersthene-hornblende pumice of unknown thickness is exposed in a cut along Forest Road 8123 at locality 66 , about $1.5 \mathrm{~km}$ north of Blue Lake. Charcoal from this deposit has a radiocarbon age of 2,910 \pm 70 years (W-2980). The deposit forms a narrow terrace in the valley of Coldspring Creek, and ashcloud deposits at least $1 \mathrm{~m}$ thick blanket the adjacent hillside to the east. About $1.5 \mathrm{~km}$ farther south, in a roadcut east of Blue Lake, a lithic pyroclastic-flow deposit that underlies tephra of set $B$ probably is also of Pine Creek age. 


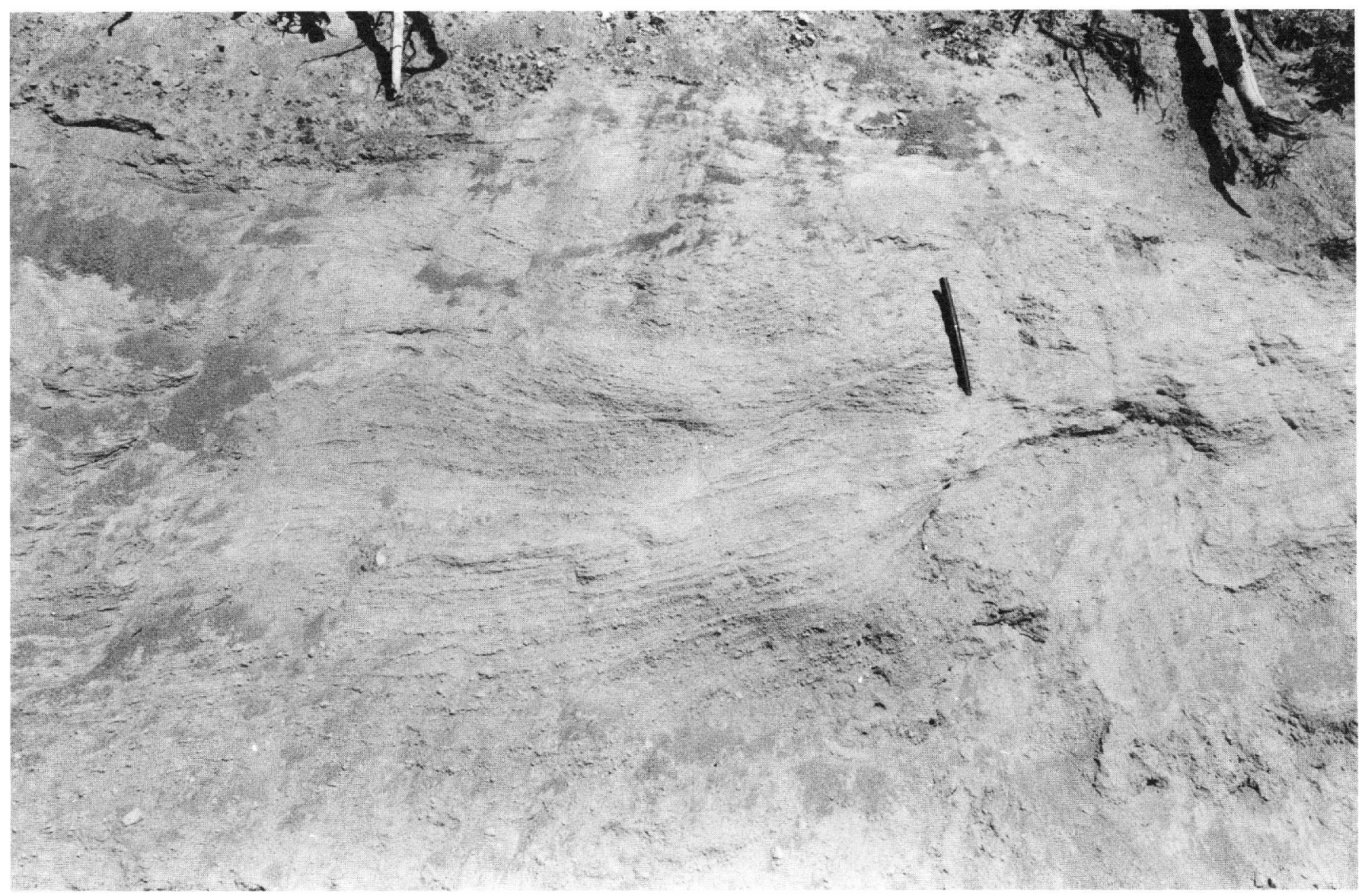

FIGURE 26.-Lithic pyroclastic-surge deposits of Pine Creek age on hillside east of Pine Creek (locality 26).

Lahars and alluvium probably of Pine Creek age are present in the Kalama River valley at a point about $35 \mathrm{~km}$ downvalley from the west base of the volcano (locality 65). There, in a roadcut adjacent to the Kalama River, two lahars interbedded with fluvial sand and gravel underlie charcoal-bearing gravel of Castle Creek age (p. 62). The lahars overlie a lahar of unknown age on which a soil is developed (measured section 7). Although the presence of cummingtonite-hornblende pumice in this older lahar suggests that it is of Smith Creek age, the degree of soil development on the deposit suggests that it is older, perhaps of Swift Creek age. The deposits at this locality form a terrace about $20 \mathrm{~m}$ above the Kalama River.

\section{Measured section 7}

[Location-roadcut adjacent to Kalama River at locality 65 near the center of sec. $31, T$. 7 N., R. 2 E.]

Deposits of Castle Creek age:

9. Lahar: rock fragments as much as $5 \mathrm{~cm}$ in diameter in matrix of gray silty sand; oxidized to depth of about $50 \mathrm{~cm}$
Deposits of Castle Creek age-Continued

Thickness
(meters)

8. Sand and gravel, chiefly rounded pebbles and cobbles of white, hypersthene-hornblende pumice; fragments of carbonized wood near base have a radiocarbon age of $2,200 \pm 60$ years (W-2436) .

Deposits of probable Pine Creek age:

7. Lahar: rock fragments mostly less than $3 \mathrm{~cm}$ in diameter in brownish-gray silty sand matrix .

6. Sand, gray; coarse at base grading to fine at top; contains scattered lapilli of hypersthene-hornblende pumice

5. Sand and pebble to cobble gravel, mottled brownishgray and light-yellowish-brown; mixed lithology includes hypersthene-hornblende pumice blocks as much as $15 \mathrm{~cm}$ in diameter; cut-and-fill stratification $\ldots \ldots \ldots \ldots \ldots \ldots \ldots \ldots \ldots \ldots$

4. Lahar: chiefly hypersthene-hornblende pumice pebbles and cobbles as much as $20 \mathrm{~cm}$ in diameter in gray sand matrix; lenticular. As much as ..... Deposits of unkmown age:

3. Lahar: rock fragments mostly less than $5 \mathrm{~cm}$ in diameter in gray sand matrix; contains fragments of hornblende-cummingtonite pumice; oxidized to depth of about $1 \mathrm{~m}$; humified to depth of about 25

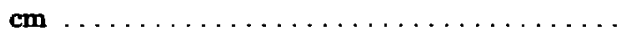




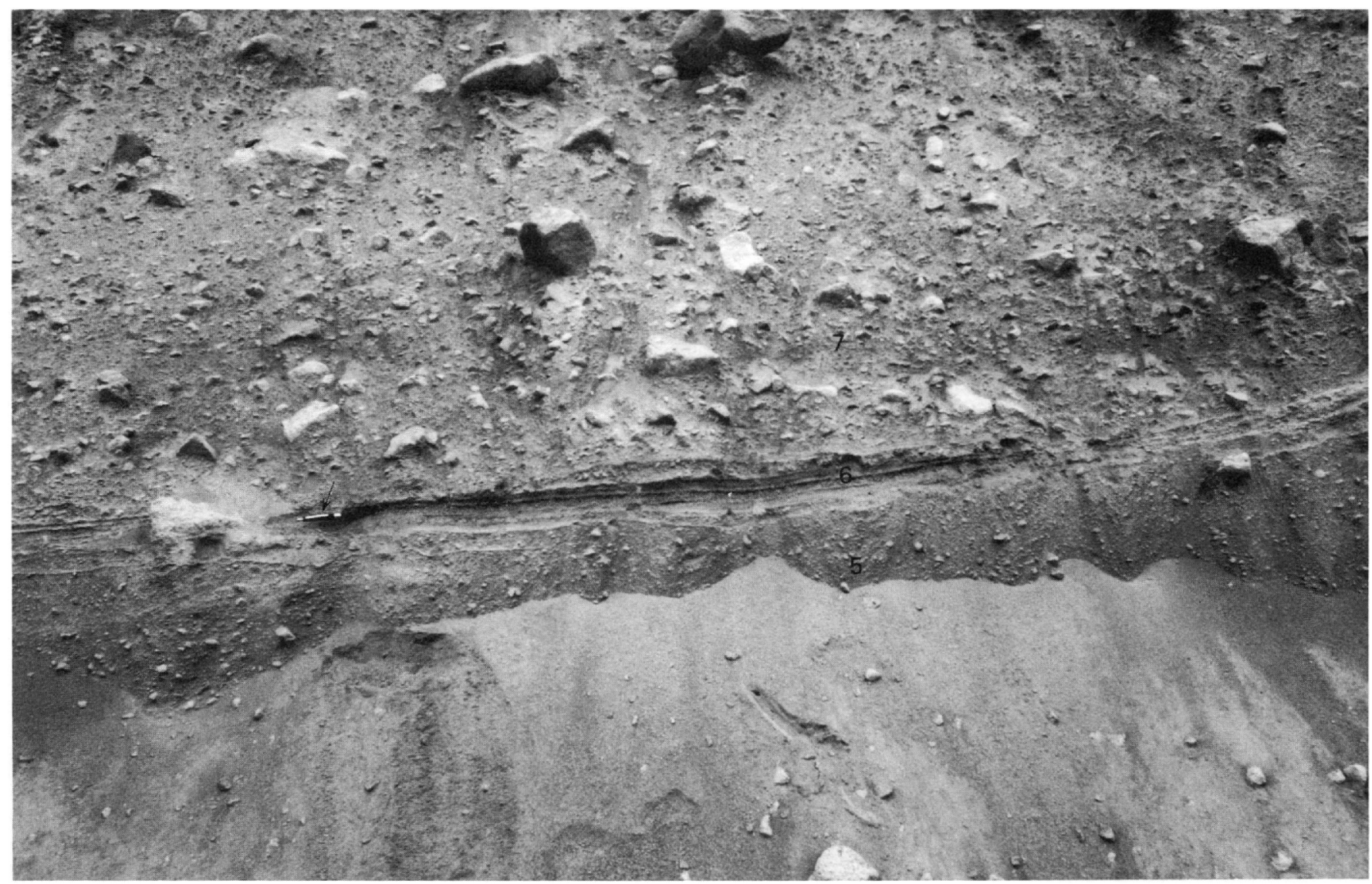

FIGURE 27.-Crossbedded and planar-bedded ash deposits (at pen point) between pyroclastic-flow deposits of Pine Creek age at locality 33 (figs. 23, 24). Numbers refer to units of measured section 6.

Deposits of unknown age-Continued

2. Sand, medium gray, horizontally bedded ..... .02-.03

1. Gravel, pebble to cobble; oxidized to yellowish brown; uppermost part is $50 \mathrm{~cm}$ of oxidized fine sand that contains scattered pebbles

Lahars also moved down the South Fork Toutle River valley during Pine Creek time. In that valley (locality 74), about $17 \mathrm{~km}$ from the west base of the volcano, a terrace about $12 \mathrm{~m}$ above the river is underlain by thin fine-grained lahars of probable Pine Creek age. Beneath the lahars a yellowish-brown deposit of sand and silt overlies cobble and boulder gravel. Lahar deposits of probable Pine Creek age crop out intermittently along the valley farther downstream; lahars moving down the South Fork valley during Pine Creek time probably merged with those in the North Fork valley.

\section{VALLEYS OF NORTH FORK TOUTLE RIVER AND CASTLE CREEK}

Lahars and pyroclastic-flow deposits of Pine Creek age formed a broad north-sloping fan that bordered the north base of the volcano before the 1980 eruptions; it reached westward from a bedrock ridge south of Spirit Lake to a bedrock ridge on the east side of Studebaker Creek (fig. 22). The deposits cropped out in a scarp along the south side of the outlet of Spirit Lake and also about $1.7 \mathrm{~km}$ south of Spirit Lake in roadcuts along the highway to Timberline Viewpoint. Coarse, crudely stratified rock debris of probable Pine Creek age also cropped out in gullies upslope from Timberline Viewpoint, and pyroclastic-flow deposits and lahars were noted in gullies at the head of Smith Creek southwest of Windy Pass.

Pine Creek deposits form a broad dissected fill (fig. 28) in the Castle Creek valley that includes both pyroclastic flows and lahars chiefly of lithic dacite debris. Before the 1980 eruptions, one pyroclastic flow cropped out in a roadcut $11.5 \mathrm{~km}$ northwest of the summit of the volcano (locality 87), where it contained lithic dacite fragments as much as $60 \mathrm{~cm}$ in diameter in a compact ash matrix. The top meter of the deposit had a reddishgray cast, and rock fragments from the deposit showed a preferred orientation of TRM, both indicating 


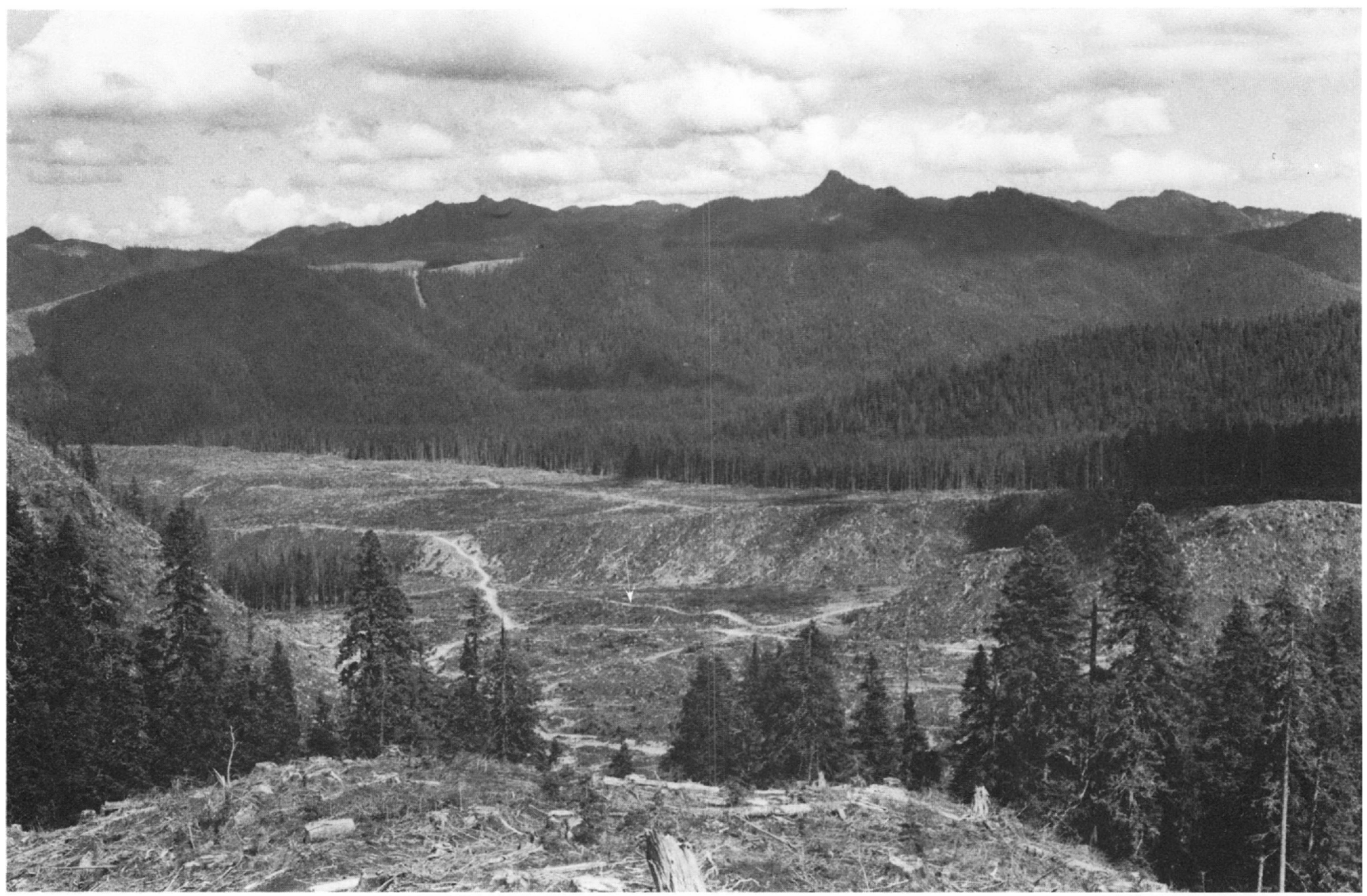

Figure 28.-View northward toward the valley of Castle Creek, which was cut into a broad, northwest-sloping fill formed by pyroclasticflow deposits and lahars of Pine Creek age northwest of Mount St. Helens. A low terrace (arrow) within the Castle Creek valley is underlain by a lava flow, a pyroclastic-flow deposit, and a lahar, all of Castle Creek age, and by a lahar of Kalama age. Photograph taken in 1977.

emplacement at a high temperature. Only lahars were seen downvalley from this locality.

Before May 18, 1980, the fill in the Castle Creek valley was exposed in many roadcuts and excavations made during logging operations. Four superposed pyroclasticflow deposits cropped out at one locality where the fill is banked against bedrock on the west side of the valley (locality 84). Charcoal from the lowest deposit had a radiocarbon age of $2,840 \pm 100$ years $(\mathrm{W}-2873)$.

The best outcrop of the units within the Castle Creek fill was in a deep gully (locality 88 ) where a succession of interbedded lahars and pyroclastic-flow deposits had an aggregate thickness of at least $75 \mathrm{~m}$. Two pyroclastic-flow deposits each about $1 \mathrm{~m}$ thick were present in the lower third of the gully; both consisted of lithic fragments in an ash matrix and had reddishgray zones at their tops. They were overlain by several lahars, above which was a pyroclastic-flow deposit about $25 \mathrm{~m}$ thick. A reddish-gray zone 2-3 $\mathrm{m}$ thick was present at its top. Above this deposit and separated from it by $1 \mathrm{~m}$ of fine gray ash was a dark-reddish-gray pyroclastic-flow deposit 4-5 m thick. A lahar $2.5 \mathrm{~m}$ thick, and lenticular ash perhaps of ash-cloud origin, topped the sequence.

Before the 1980 eruptions, ash-cloud deposits of Pine Creek age mantled the bedrock ridge that borders Studebaker Creek and forms the east boundary of the fill in the Castle Creek valley. Deposits as much as $2.5 \mathrm{~m}$ thick were noted on the west side of this ridge in section 19.

Pyroclastic flows and lahars moving down the Castle Creek valley extended out into the valley of the North Fork Toutle River where they formed a thick fill downstream from the mouth of Studebaker Creek (fig. 22). Repeated damming of the North Fork Toutle River by pyroclastic flows probably was followed by overtopping of the dams, rapid downcutting, and remobilization of some of the rock debris to form lahars that flowed down the valley.

The Castle Creek fill of Pine Creek age also temporarily blocked valleys that join the North Fork Toutle River valley from the north. Seven lahars $0.3-3 \mathrm{~m}$ thick 
separated by beds of fluvial sand 0.5-2 $\mathrm{m}$ thick were locally exposed prior to 1980 in the south bank of North Coldwater Creek (locality 89). The lowest lahars contained abundant pumice and a few breadcrusted blocks of dacite. Before the 1980 eruptions, this north-sloping backfill caused South Coldwater Creek to flow $1 \mathrm{~km}$ northwestward to join North Coldwater Creek.

Lahars of Pine Creek age form terraces along the valleys of the North Fork Toutle River and Toutle River downstream to the Cowlitz River. These lahars and the fluvial deposits interbedded with them were informally referred to as the Silver Lake lahar assemblage by Mullineaux and Crandell (1962). Near the mouth of Alder Creek (locality 81), some $30 \mathrm{~km}$ downvalley from the base of the volcano, lahars exposed in a gravel pit (measured section 8 ) form a terrace about $10 \mathrm{~m}$ above the North Fork. The lowest lahar exposed in the walls of the pit is more than 2,900 radiocarbon years old and probably is of Smith Creek age; the upper three lahars evidently were formed during the Pine Creek eruptive period.

\section{Measured section 8}

[Location-gravel pit in valley of North Fork Toutle River near mouth of Alder Creek (locality 81 ) in the SW1/4 sec. 15, T. 10 N., R. 2 E.]

Deposits of Pine Creek age: Thickness (meters)

7. Lahar: subangular to subrounded clasts of dacite as much as $30 \mathrm{~cm}$ in diameter in matrix of fine to medium gray sand and granules; grain size de creases from bottom to top; thickness increases northward, toward center of valley. As much as

6. Sand, fine to coarse, yellowish brown

5. Lahar: subangular to subrounded clasts of dacite as much as $50 \mathrm{~cm}$ in diameter in gray sand matrix; grain size decreases from bottom to top; thickness increases northward. As much as

4. Sand, fine to medium, gray; scattered pebbles; lenticular. As much as

3. Lahar: subangular to subrounded clasts of dacite as much as $35 \mathrm{~cm}$ in diameter in matrix of silty fine to medium sand, gray ............. Deposits of Smith Creek(?) age:

2. Sand, fine to medium, gray and locally yellowishbrown; silty and humified in upper $20-25 \mathrm{~cm}$; upper part contains carbonized wood fragments that have a radiocarbon age of $2,900 \pm 70$ years (W-2875)

1. Lahar: subangular to subrounded clasts of dacite in silty sand matrix; very compact; gray with purplish cast

Twenty kilometers farther downvalley, deposits of Pine Creek age are especially well exposed in the sides of a gravel pit near Toutle Lake (Gilmore Corners) (locality 77). Those deposits include three lahars each 3-6 $\mathrm{m}$ thick consisting of nonvesicular rock fragments in a sand matrix; they are interbedded with fluvial sand and gravel of similar lithology (Mullineaux and Crandell,
1962). The lowest unit exposed in the gravel pit is a 6-m-thick lahar, the base of which can be seen in the adjacent bank of Outlet Creek where it overlies a deposit of humified fine sand $20 \mathrm{~cm}$ thick (fig. 29). Wood fragments in the sand had a radiocarbon age of $2,810 \pm 70$ years (W-3265). Beneath the sand is a humified zone and other sand layers that contain pumice mineralog. ically similar to pumice in tephra set $Y$. These sand beds overlie a lahar of Smith Creek(?) age more than $1.5 \mathrm{~m}$ thick that extends below the level of Outlet Creek. The deposits of Pine Creek age form a west-sloping backfill that is responsible for impounding Silver Lake in a valley tributary to the Toutle River (Mullineaux and Crandell, 1962).

A wood fragment in the lowest lahar exposed in the gravel pit was reported to have a radiocarbon age of 2,030 \pm 240 years (W-811; Mullineaux and Crandell, 1962). This age seems to be too young inasmuch as the lahar and those that overlie it seem to be typical deposits of the Pine Creek eruptive period. The possibility was considered that they are products of the Castle Creek eruptive period, perhaps genetically related to pyroclastic-flow deposits in the Castle Creek area from which radiocarbon dates have been obtained that range from about 2,060 to about 2,200 years. However, those pyroclastic flows are pumiceous, of relatively small volume, and lie within a valley cut into radiocarbondated deposits of Pine Creek age. The deposits of Pine Creek age in the Castle Creek valley are chiefly of nonvesicular rock debris and resemble the deposits at Toutle Lake. The large volume of the Pine Creek deposits close to the volcano also suggests that they are more likely to be the near-source correlatives of the deposits far downvalley.

The flood of volcanic rock debris from Mount St. Helens aggraded the Cowlitz River valley below the mouth of the Toutle. The resulting fill forms a terrace just upstream from the community of Castle Rock that is about $6 \mathrm{~m}$ higher than the Cowlitz River. Two finegrained lahars and fluvial sand and gravel in the terrace deposit crop out in the sides of a gravel pit about $2 \mathrm{~km}$ northwest of Castle Rock (measured section 9), at a downvalley distance of about $65 \mathrm{~km}$ from the mouth of Castle Creek. At the gravel pit some boulders of dacite from Mount St. Helens, presumably carried by the lahars, are as much as $1 \times 1.5 \times 2 \mathrm{~m}$ in size.

\section{Measured section 9}

[Location-walls of gravel pit $2 \mathrm{~km}$ northwest of Castle Rock in the SW1/4 sec. 3, T. 9 N., R. 2 W.] (meters)

Deposits of Pine Creek age:

10. Sand and pebble to cobble gravel; locally oxidized to depth of as much as $70 \mathrm{~cm}$; mixed lithology but chiefly from Mount St. Helens volcano .. 


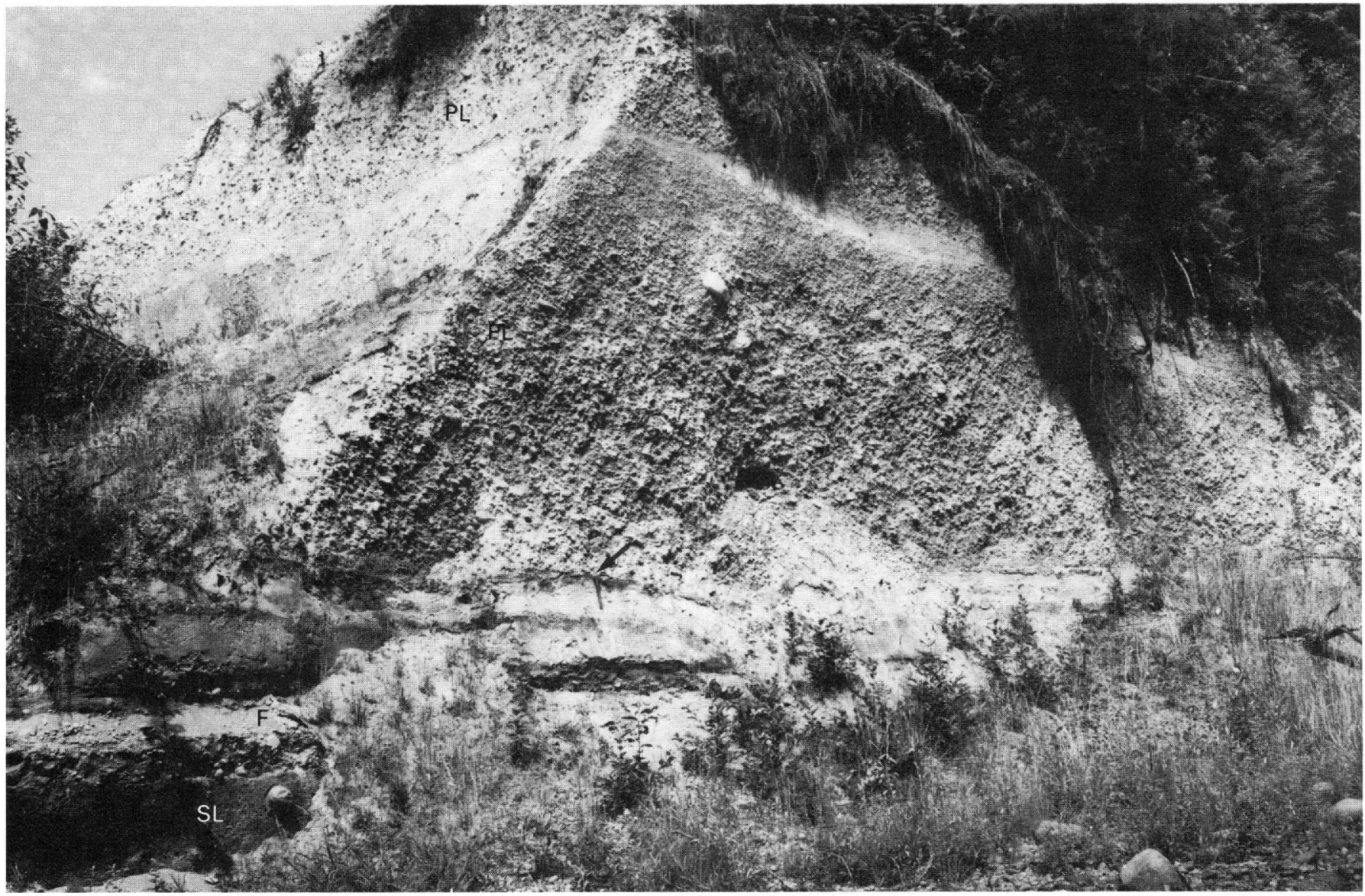

Figure 29.-Lahars of Pine Creek age (PL) overlying a fluvial deposit (F) and a lahar of Smith Creek(?) age (SL) in bank of Outlet Creek near Toutle Lake (locality 77). Pick in lower center of photograph shows scale.

Deposits of Pine Creek age-Continued

9. Lahar: subangular and subrounded rock fragments mostly less than $1 \mathrm{~cm}$ in diameter in matrix of medium to coarse gray sand; lenticular. As much as

8. Sand and granule gravel, loose, crossbedded, gray; contains pebbles of hypersthene-hornblende pumice

7. Sand, fine to medium, gray, horizontally bedded

6. Silt and fine sand; grayish brown; lenticular. As much as

5. Lahar: subangular and subrounded rock fragments mostly less than $2 \mathrm{~cm}$ in diameter in compact matrix of gray silty sand; grades upward to sandand granule-sized material at top

4. Sand, fine, gray

3. Sand, medium to very coarse; grades down into coarse sand and granule gravel

2. Silt and very fine sand, gray; locally humified; contains abundant organic matter

Deposit of pre-Pine Creek age:

1. Pebble and cobble gravel; oxidized dark yellowish orange; stones are coated with iron oxides; forms floor of gravel pit

\section{NATURE AND AGE OF VOLCANISM}

Pine Creek time was characterized by the eruption of small volumes of tephra and the formation of many pyroclastic flows, in contrast to the Smith Creek eruptive period when much larger volumes of pumiceous tephra were erupted but fewer pyroclastic flows occurred.

The Pine Creek eruptive period evidently was separated from the preceding eruptive period by an interval of about 300 years, if the youngest Smith Creek deposits and the oldest Pine Creek deposits have been recognized and accurately dated. Radiocarbon dates on deposits of Pine Creek age suggest that the eruptive period spanned about 500 years, but the volcano probably was not erupting continuously for five centuries. Instead, eruptions probably occurred during repeated short-lived episodes of intense activity.

Much of the material deposited by pyroclastic flows and lahars during Pine Creek time probably originated at domes. Remnants of several domes older than tephra set B have been recognized by C. A. Hopson (unpub. 
map, 1977), and some of these may be of Pine Creek age. Other domes and short lava flows may be buried by the modern cone. Pyroclastic eruptions during Pine Creek time included pumice and nonvesicular rock, both represented by tephra of set $\mathrm{P}$ and by pyroclastic-flow deposits (Crandell and Mullineaux, 1973).

Except for the domes, the highest deposits of Pine Creek age at the volcano are at an altitude of only about $1,600 \mathrm{~m}$. The highest dome remnant of possible Pine Creek age is at an altitude of about $2,200 \mathrm{~m}$ on the southwest flank of Mount St. Helens, about $750 \mathrm{~m}$ below the pre-1980 summit of the volcano (C. A. Hopson, unpub. map, 1977). The fact that only fragmental material is seen in outcrops at the base of Mount St. Helens suggests that during Pine Creek time the volcano consisted of irregular piles of coarse debris that surrounded one or more domes. Remnants of old domes exposed since May 1980 in the new crater walls of Mount St. Helens (Hopson and Melson, 1982) may be of Pine Creek age.

Crandell and Mullineaux (1973) inferred that some kind of topographic feature prevented volcanic debris from moving into valleys north and west of the volcano during Pine Creek time. This inference was based on our apparently erroneous conclusion that lahars in the North Fork Toutle River valley are younger than the Pine Creek eruptive period. I now believe those deposits to be products of that period, and that pyroclastic flows and lahars extended away from the volcano to the north and west as well as to the south.

\section{CASTLE CREEK ERUPTIVE PERIOD}

The Castle Creek eruptive period, between about 2,200 and 1,600 years ago (table 8), was characterized by eruptions of andesite, dacite, and basalt. Andesite was produced during eruptive episodes twice during the period and formed lava flows, lahars, and often-repeated small volumes of tephra. Eruptions of dacite that occurred during the middle part of the period formed pumiceous pyroclastic flows, air-fall tephra, and at least one pyroclastic surge; basalt erupted at and near the end of the period formed air-fall tephra and lava flows. The inferred stratigraphic succession of Castle Creek eruptive products is shown in table 9.

Some radiocarbon dates from deposits of Castle Creek age are consistent with the stratigraphic succession but others are not, and it is not possible to state with certainty which dates, if any, are correct or nearly so. Although radiocarbon dates from Pine Creek deposits suggest that the Pine Creek eruptive period ended about 2,500 years ago, one date from a Castle Creek deposit is about 2,660 years B.P. (table 9).
The succession of rock types erupted during Castle Creek time that was inferred before 1981 included two consecutive sequences of andesite-dacite-basalt (Mullineaux and Crandell, 1981). The position of the earliest basalt in this succession was based on its radiocarbon age. Subsequent discovery that the Cave Basalt was erupted at or near the end of Castle Creek time, however, shows that it was contemporaneous with the other basalt flows of the eruptive period. Basalt thus was erupted only at the end of the period.

The previously inferred repetition of dacite eruptions twice during the period was based primarily on three radiocarbon dates between 2,060 and 2,200 years on samples from pyroclastic-flow deposits on the west side of the volcano, and bracketing dates of 1,780 and 1,850 years on a dacitic tephra layer east of the volcano. However, the tephra is mineralogically similar to the pumiceous pyroclastic-flow deposits (D. R. Mullineaux, oral commun., 1983), which suggests that they are genetically related; no unequivocal stratigraphic evidence exists of andesitic eruptive products between the dacitic eruptive products. The stratigraphic relation of the pyroclastic-flow deposits and tephra layer $\mathrm{Bd}$ west of the volcano to tephra layer $\mathrm{Bi}$ east of the volcano is not known.

In the following discussion of the eruptive products of Castle Creek time, those on the northwest side of the volcano are described first, and other areas are treated in clockwise succession around the volcano (fig. 30).

\section{DEPOSITS}

PYROCLASTIC-FLOW DEPOSITS AND LAVA FLOWS IN AND NEAR THE CASTLE CREEK VALLEY

Castle Creek no longer heads on Mount St. Helens, but it did so during and after the Castle Creek eruptive period; consequently, lava flows and pyroclastic flows could descend northwestward from the volcano along that valley.

The stratigraphic record of Castle Creek time in the Castle Creek area includes the following units, which are arranged in order of age, oldest at the bottom:

lava flow of olivine basalt;

lava flow of hypersthene-augite andesite;

pumiceous pyroclastic-flow deposits, 2,100-2,200

years old (hypersthene-bearing pumice);

tephra of layer Bh (hypersthene-augite scoria);

lava flow and lahars of hypersthene-augite andesite.

The oldest lava flow (unit 1, measured section 10) extends down the Castle Creek valley and terminates near locality 86. A chemical analysis of this flow showed a $\mathrm{SiO}_{2}$ content of $\mathbf{5 7 . 7 6}$ percent (sample 8 , 


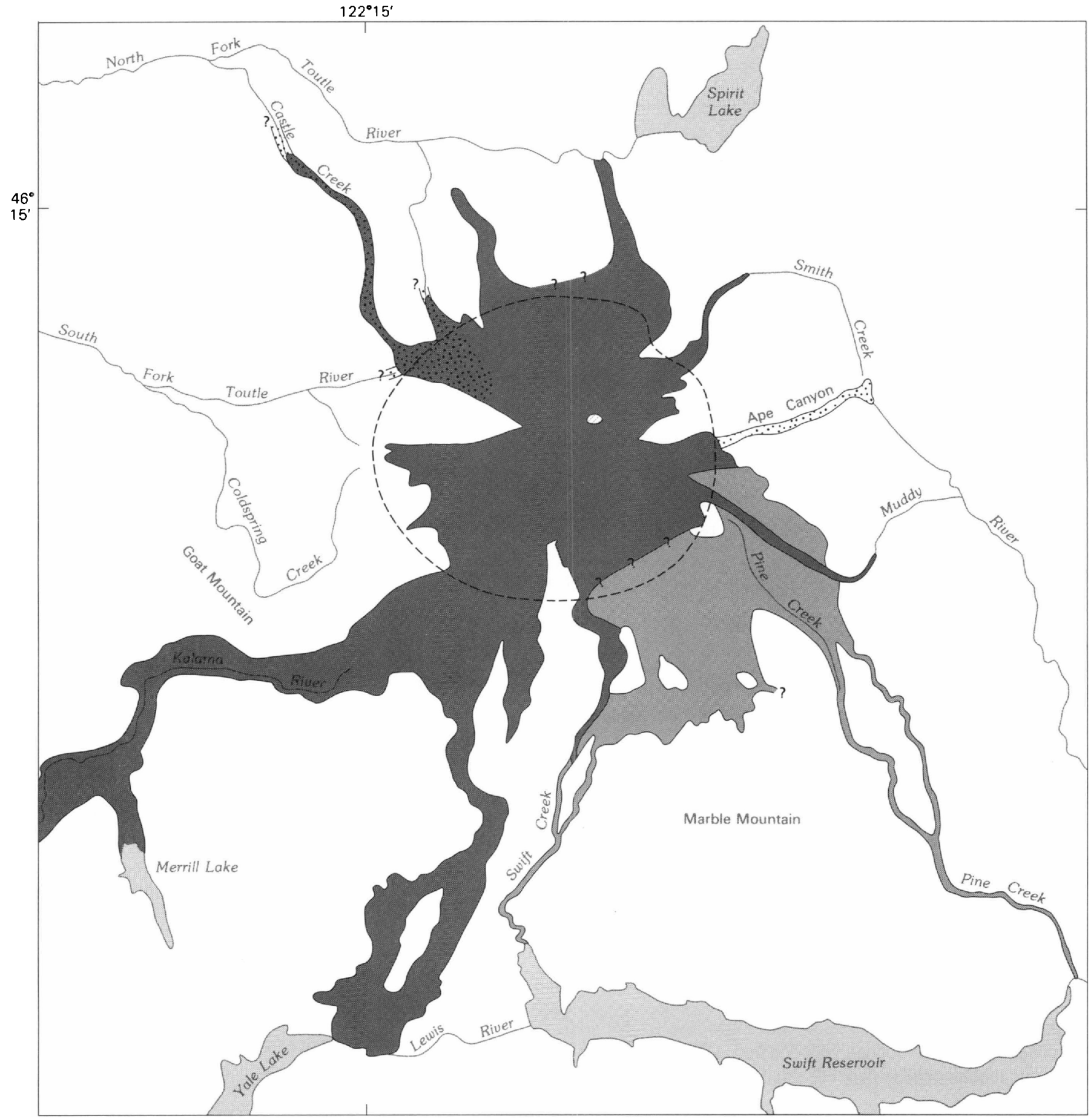

o 5 KILOMETERS

EXPLANATION

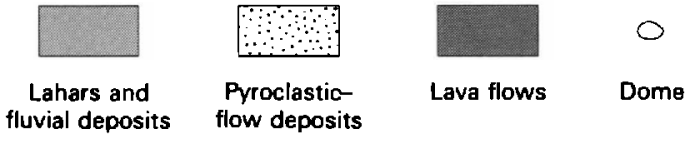

FIGURE 30.-Sketch map showing inferred distribution of pyroclastic-flow deposits, lahars, fluvial deposits, and a dome of Castle Creek age at Mount St. Helens. Based chiefly on unpublished geologic map by C. A. Hopson. Dashed line shows the base of the volcano. 
TABLE 9.-Inferred composite stratigraphic section, with pertinent ${ }^{14} \mathrm{C}$ dates, for the Castle Creek eruptive period

[a, andesite; b, basalt; d, dacite. Tephra units are from Mullineaux and Crandell (1981), and D. R. Mullinesux (oral commun., 1983) ----radiocarbon dates not available.]

\begin{tabular}{|c|c|c|}
\hline Tephra units & Other eruptive products & ${ }^{14} \mathrm{C}$ dates \\
\hline \multirow{3}{*}{$\mathrm{Bu}(\mathrm{b})$} & \multirow[t]{3}{*}{ Lava flows(b) } & 1,$860 ; 1,925$ \\
\hline & & $\begin{array}{l}1,670 \\
1,740\end{array}$ \\
\hline & & ---- \\
\hline $\mathrm{B} 1(\mathrm{~d})$ & & $\begin{array}{l}1,780 \\
1,850\end{array}$ \\
\hline$B d(d)$ & Pyroclastic-flow deposits & $\begin{array}{l}2,060 \\
2,100 \\
2,200\end{array}$ \\
\hline $\mathrm{Bo}(\mathrm{a})$ & & $\cdots$ \\
\hline & Lava flow(a), lahars & $\cdots$ \\
\hline $\mathrm{Bh}(\mathrm{a})$ & & $\cdots$ \\
\hline & Lava flow(a), lahars & 2,660 \\
\hline
\end{tabular}

app. A). The valley in which the flow lies is cut into deposits of Pine Creek age from which a sample with a radiocarbon age of about 2,800 years was obtained.

\section{Measured section 10}

[Location-cut on south side of logging road on floor of Castle Creek valley (locality 85) in the NW1/4 sec. $24, T$. 9 N., R. 4 E.]

\section{Thickness (meters)}

Deposits of Kalama age:

8. Lahar(?): dacite rock debris from summit dome; some blocks prismatically jointed; wood fragments in the deposits not charred ...............

7. Tephra of set X: fine ash, black to very dark brown at top; grading down to mottled gray and brown
Deposits of Castle Creek age:

6. Lahar: rock fragments as much as $\mathbf{1 5} \mathrm{cm}$ in diameter in gray sand matrix; oxidized yellowish brown in upper $10 \mathrm{~cm} \ldots \ldots \ldots \ldots \ldots \ldots \ldots \ldots \ldots$

5. Ash, fine, gray; lenticular; as much as .......

4. Pyroclastic-flow deposit: clasts of slightly pumiceous hypersthene-bearing dacite (about 80 percent), some breadcrusted, and nonvesicular dacite (about 20 percent) in gray ash matrix; contains charcoal that has a radiocarbon age of $2,200 \pm 60$ years

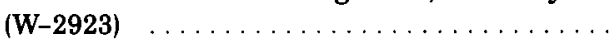

3. Ash, pumiceous, gray $\ldots \ldots \ldots \ldots \ldots \ldots \ldots$

2. Tephra of layer Bh: hypersthene-and augite-bearing scoriaceous ash and lapilli $\ldots \ldots \ldots \ldots \ldots \ldots$

Thickness (meters)

$.1-.2$

1. Rubbly top of hypersthene-augite andesite lava flow
.22

$>1$ 


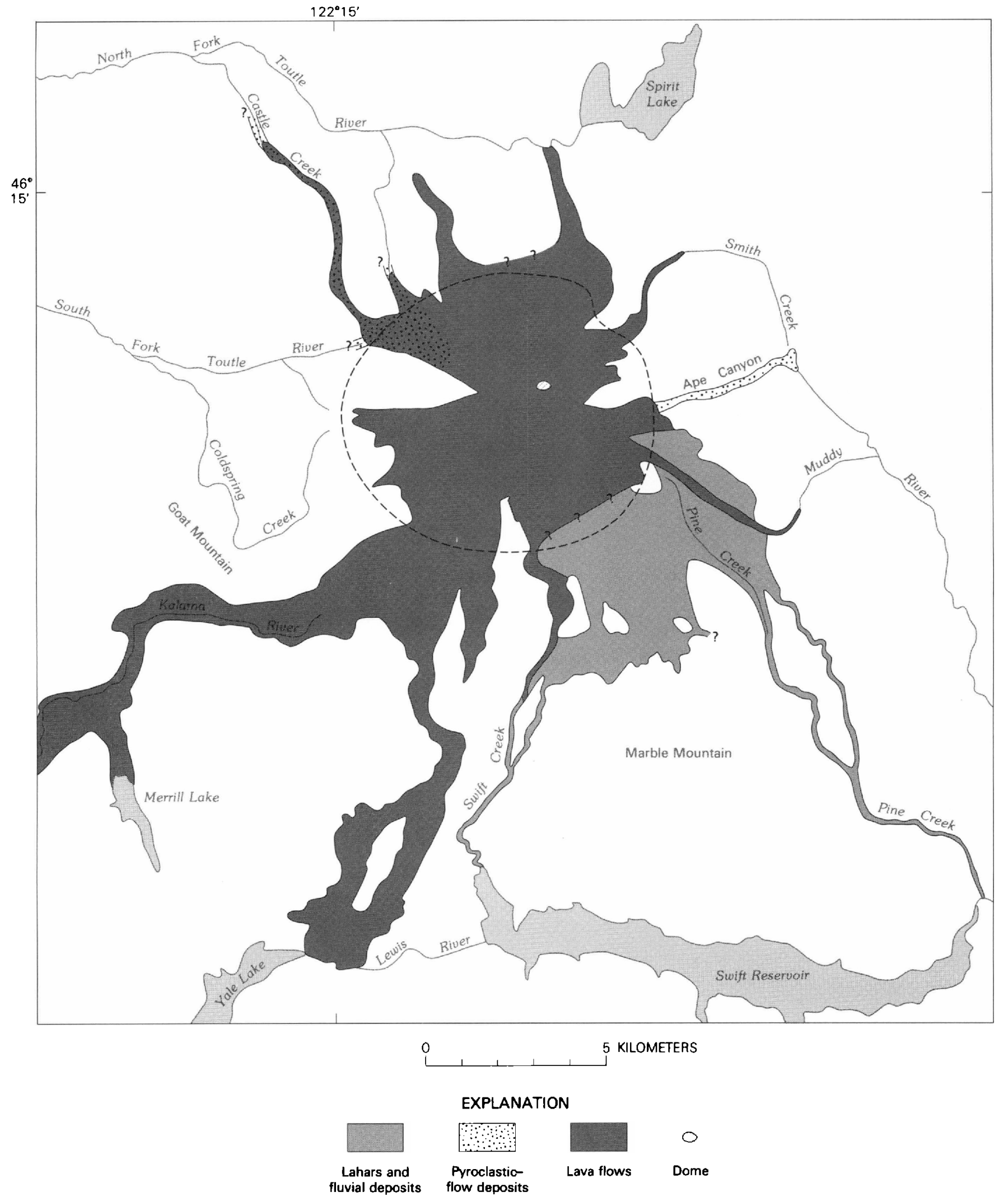

FigURE 30.-Sketch map showing inferred distribution of pyroclastic-flow deposits, lahars, fluvial deposits, and a dome of Castle Creek age at Mount St. Helens. Based chiefly on unpublished geologic map by C. A. Hopson. Dashed line shows the base of the volcano. 
The next-younger deposits in the Castle Creek area are two or more pumiceous pyroclastic-flow deposits, which crop out on the floor of the Castle Creek valley, in the west canyon wall of Studebaker Creek, and in the north canyon wall of the South Fork Toutle River. Most rock fragments in these deposits consist of hypersthenebearing pumice that contains traces of hornblende and augite.

Before the 1980 eruptions the pyroclastic-flow deposit on the floor of the Castle Creek valley was exposed beside a logging road that cut through a terrace about $10 \mathrm{~m}$ higher than Castle Creek (locality 85 ; fig. 28). The deposit had a matrix of gray ash and contained fragments of hypersthene-bearing pumiceous dacite, some of them breadcrusted, as well as fragments of nonvesicular dacite (measured section 10). A chemical analysis of a breadcrusted pumice clast showed a $\mathrm{SiO}_{2}$ content of 63.26 percent (sample 9, app. A). Fragments of charcoal were abundant in the deposit, one of which yielded radiocarbon dates of $2,200 \pm 60$ years ( $W-2923)$ and 2,220 \pm 50 years (W-2872). The pyroclastic-flow deposit was underlain by gray pumiceous ash, beneath which were hypersthene- and augite-bearing ash and lapilli of tephra layer $\mathrm{Bh}$ and the andesite lava flow described previously.

Breadcrusted blocks of pumice mineralogically similar to those in the pyroclastic-flow deposit and as large as $30 \mathrm{~cm}$ in diameter were scattered on the surface of the andesite flow near its terminus (locality 86 ). These fragments were not accompanied by a fine matrix. The top of the lava flow in that area was some 10-15 m higher than the adjacent floor of the Castle Creek valley. The way in which the blocks were deposited on top of the lava flow is not known.

A pumiceous pyroclastic-flow deposit is exposed beneath a lava flow of vesicular basalt in the west wall of the canyon of Studebaker Creek (locality 83). The deposit is 1-2 $\mathrm{m}$ thick and contains clasts of nonvesicular dacite as well as hypersthene-bearing pumice containing minor augite. A sample from a charcoal log in the deposit had a radiocarbon age of $2,100 \pm 50$ years (W-2978). The pyroclastic-flow deposit is underlain by about $4 \mathrm{~m}$ of stratified lithic sand of unknown age that is oxidized to a depth of about half a meter; in the middle of the sand are beds of pumiceous ash and lapilli. The sand is underlain by $1.7 \mathrm{~m}$ of fine sand or ash that is oxidized throughout, beneath which is a succession of pyroclastic-flow deposits and lahars of Swift Creek(?) age more than $20 \mathrm{~m}$ thick.

Two pyroclastic-flow deposits consisting chiefly of hypersthene-bearing pumice with minor hornblende and augite crop out beneath an andesite lava flow in the north canyon wall of the South Fork Toutle River (locality 80 ) (measured section 11), about $1 \mathrm{~km}$ southwest of locality 83. A sample of charcoal from the upper deposit had a radiocarbon age of $2,060 \pm 50$ years (W-2977). Airfall tephra between the two deposits consists of ash and lapilli of lithic dacite and pumice that contains hypersthene and minor amounts of hornblende and augite.

Measured section 11

[Location-near top of north canyon wall of South Fork Toutle River at locality 80 in the NW1/4SW1/4 sec. 31, T. 9 N., R. 5 E.J

\section{Thickness}

(meters)

Rocks and unconsolidated deposits of Castle Creek age:

7. Lava flow of hypersthene-augite andesite. Estimated

6. Pyroclastic-flow deposit: lapilli and blocks of hypersthene-bearing pumice that contains minor hornblende and augite, some breadcrusted, in gray ash matrix; contains charcoal fragments which have a radiocarbon age of $2,060 \pm 50$ years (W-2977); top concealed by colluvium

5. Air-fall tephra of layer Bd: lapilli of lithic dacite and hypersthene-bearing pumice that contains minor hornblende and augite

4. Pyroclastic-flow deposit: lapilli of gray dacite and pumice in gray ash matrix; contains charcoal

3. Silt and sand; humified in upper $3 \mathrm{~cm}$; grades down into reddish-brown sand; contains scattered small blocks of pumiceous gray dacite; lenticular. As much as ..................

2. Lahar(?): lithic rock fragments in gray sand matrix; lenticular. As much as . ........ Deposits of Swift Creek(?) age:

1. Lahars and pyroclastic-flow deposits; oxidized to depth of about $30 \mathrm{~cm}$ at top

At another outcrop near the top of the canyon wall (locality 78), about $0.4 \mathrm{~km}$ west of measured section 11 , lahars and pyroclastic-flow deposits fill a channel cut into deposits of Swift Creek(?) age (measured section 12). Several lahars near the base of the Castle Creek deposits contain pyroxene andesite rock debris. The basal lahar of the sequence is overlain by wood-bearing sand from which a radiocarbon date of $2,660 \pm 80$ years (W-4004) was obtained. This date seems to be too old because it is significantly greater than other dates on the Castle Creek eruptive period (table 8) and overlaps dates on some deposits of Pine Creek age.

Measured section 12

[Location-near top of north canyon wall of South Fork Toutle River at locality 78 in the SE $1 / 4$ SE $1 / 4$ sec. 36 , T. 9 N., R. 4 E.]

Thickness (meters)

Deposits of Kalama age:

15. Pyroclastic-flow deposit: lapilli of lithic dacite and pumice in grayish-brown lithic ash matrix . .

14. Lahar: rock debris consisting chiefly of nonvesicular dacite from summit dome; lenticular. As much as

1.0

13. Sand, very fine to medium, gray, planar bedded and crossbedded; contains layers of granule and pebble gravel and scattered cobbles. As much as 


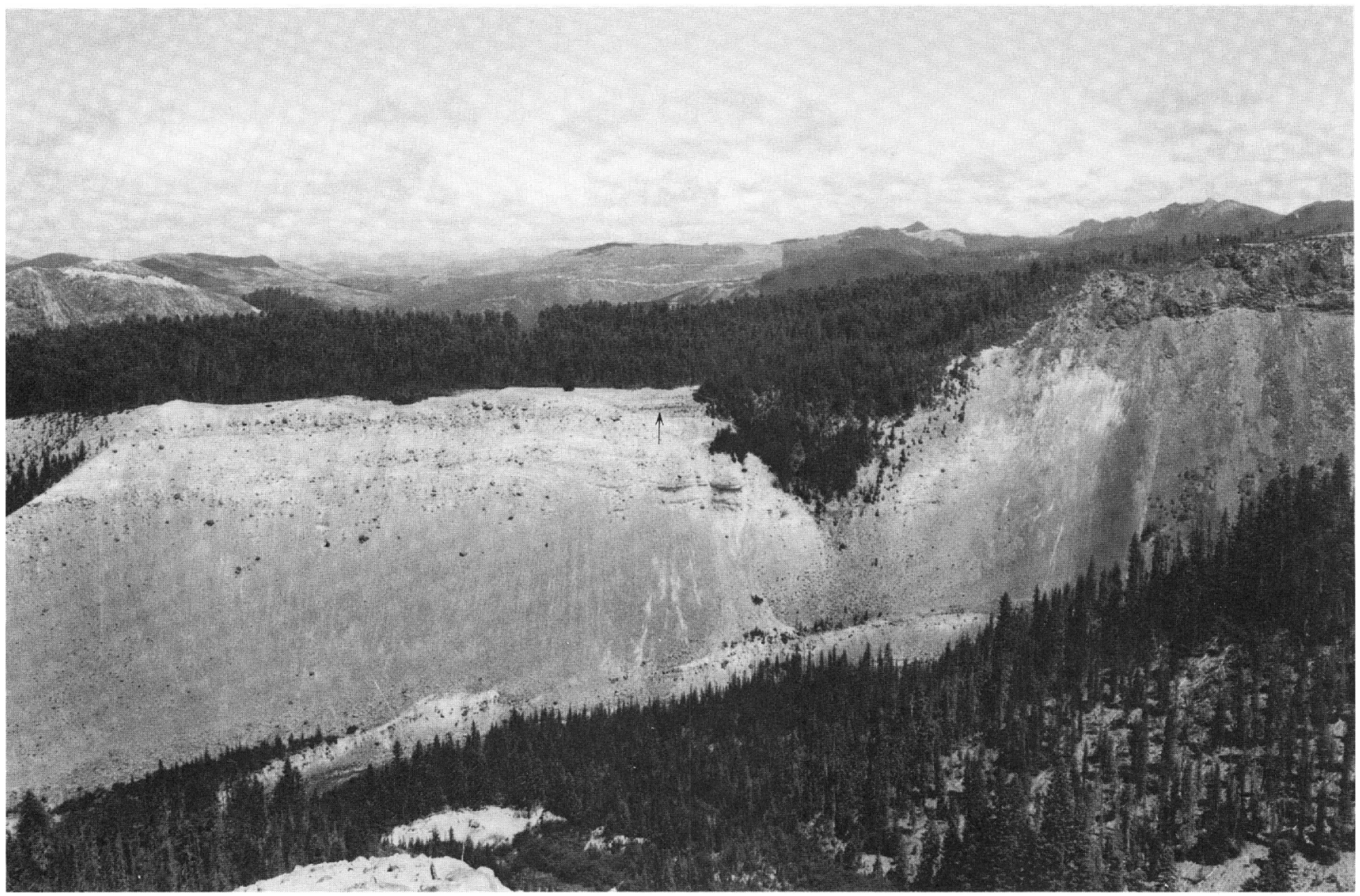

FIGURE 31.-View north-northwest toward the north canyon wall of the South Fork Toutle River. Conspicuously stratified units are pyroclastic-flow deposits and lahars of Swift Creek(?) age, at the top of which is a channel filled with deposits of Castle Creek and Kalama ages (arrow), which is the location of measured section 12. Photograph taken in 1974.

Deposits of Kalama Creek age-Continued

12. Lahar or pyroclastic-flow deposit: chiefly subangular and subrounded fragments of light-gray dacite from summit dome in gray sand matrix; some blocks prismatically jointed

11. Very fine sand and silt; lenticular. As much as

10. Sand, fine to very fine; lenses of pumiceous ash

9. Tephra of set X: lithic and pumiceous ash, grayish brown; lenses of black lithic olivine-bearing ash

8. Ash, lapilli, and small blocks of hypersthenehornblende pumice; lower $20 \mathrm{~cm}$ contains abundant charcoal and probably is a pyroclastic-flow deposit; middle 3-8 $\mathrm{cm}$ planar bedded and probably formed by a pyroclastic surge; upper $20 \mathrm{~cm}$ probably a second pyroclastic-flow deposit; contacts between units locally irregular

7. Sand, fine and very fine, gray and yellowish brown. horizontally bedded

Deposits of Castle Creek age:

6. Tephra of layer Bu: dark-yellowish-brown ash with scattered lapilli of black olivine-bearing scoria near base (meters)
Deposits of Castle Creek age-Continued

Thickness (meters)

5. Pyroclastic-flow deposit(?): ash, lapilli, and small blocks of hypersthene-bearing pumice and lithic dacite; humified at top

4. Lahars: lenticular deposits of rock debris consisting chiefly of dark-gray andesite in gray sand matrix

3. Sand, fine; contains scattered pumice lapilli and abundant organic matter, including wood fragments that have a radiocarbon age of $2,660 \pm 80(\mathrm{~W}-4004)$ and conifer needles .....

2. Lahar: chiefly dark-gray fragments of pyroxene andesite in gray sand matrix; lenticular. As much as

Deposits of Swift Creek(?) age:

1. Lahars and pyroclastic-flow deposits, oxidized to depth of about $50 \mathrm{~cm}$ at top

The andesite lava flow that forms the top of the north canyon wall at measured section 11 terminates less than $100 \mathrm{~m}$ west of that locality (figs. 31,32 ) in a steep front 40-50 m high; a remnant of the same flow can also be seen at the top of the opposite canyon wall. The flow moved downslope on a broad, northwest- and west-sloping 


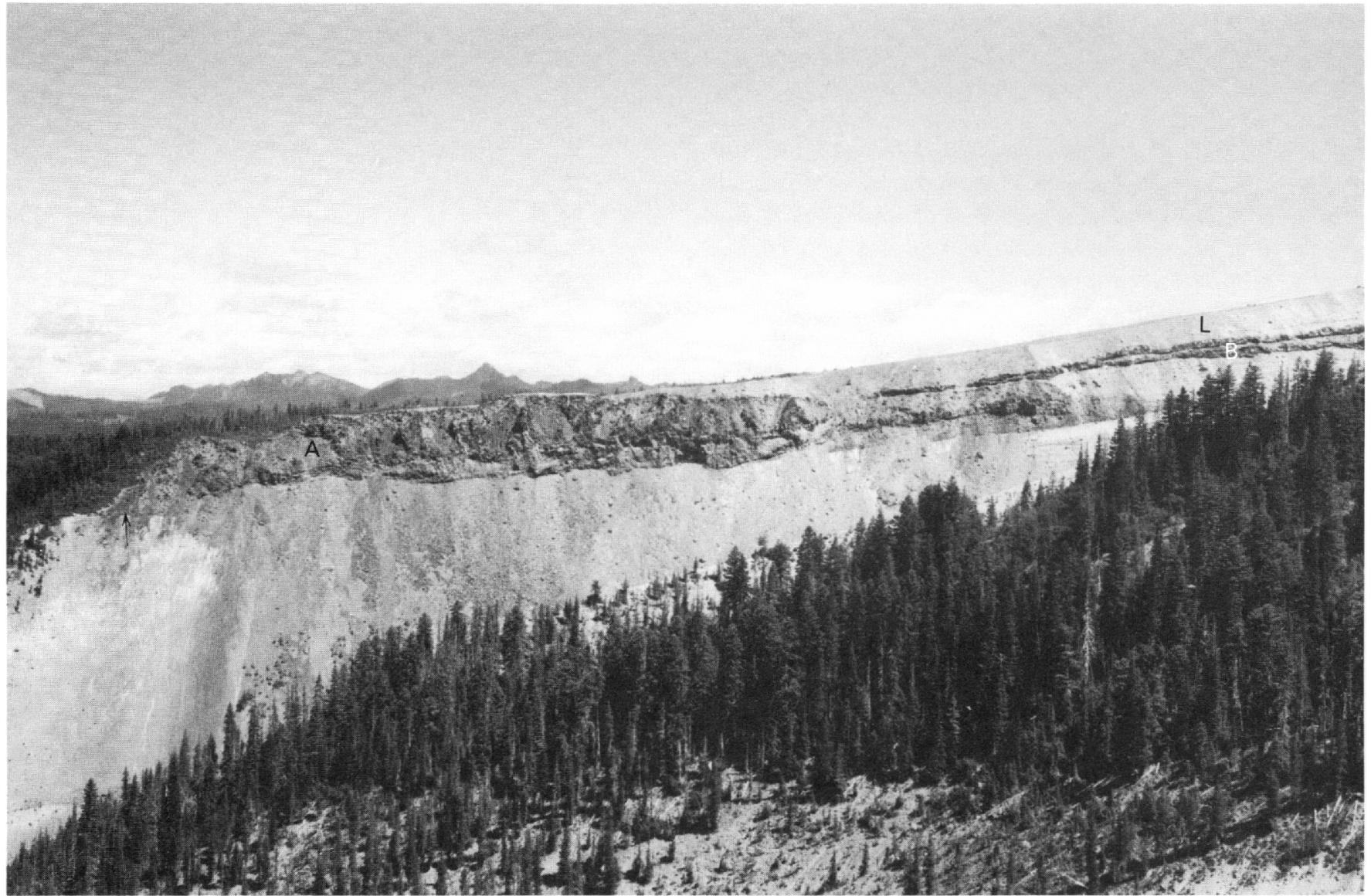

Figure 32.-View northeast toward the north canyon wall of the South Fork Toutle River. Arrow points to location of thin deposits of Cagtle Creek age beneath andesite lava flow (A) at measured section 11. Thin lava flows at right (B) are basalt of Castle Creek age, which are overlain by lahars (L) of dacitic rock debris from the summit dome of Kalama age. Photograph taken in 1974.

fan of pyroclastic-flow deposits and lahars that was locally overlain by thin deposits of Castle Creek age. A deep canyon similar to the one today at the head of the South Fork Toutle River did not exist during the Castle Creek eruptive period.

The andesite flow is overlain by an olivine basalt flow (fig. 32), which also crops out in the upper canyon of Studebaker Creek and which probably correlates with a basalt flow in the Castle Creek valley near the south edge of section 25 .

LAVA FLOWS ON THE NORTH AND NORTHEAST SIDES OF THE VOLCANO

The longest andesite lava flow on the north flank of the volcano terminates at a point about $1.7 \mathrm{~km}$ southeast of the mouth of Studebaker Creek (C. A. Hopson, unpub. map, 1977). It evidently heads high on the northwest side of the volcano, but most of its length is covered by an andesite flow (the "floating island" lava flow, p. 85) of Goat Rocks age. The flow of Castle Creek age probably is contemporaneous or nearly so with the andesite flow in the Castle Creek valley.

Farther east, the longest basalt flow on the north side of the volcano cropped out before the 1980 eruptions in the south bank of the North Fork Toutle River about $1 \mathrm{~km}$ southwest of Spirit Lake (locality 2). The lava flow postdates tephra set B. Verhoogen (1937, p. 284) suggested that this flow was responsible for damming the river valley to produce the basin of Spirit Lake. But this basin existed before Castle Creek time, dammed by lahars and pyroclastic flows during, if not before, the Smith Creek and Pine Creek eruptive periods. Before the 1980 eruptions, a succession of five or more basalt flows, each a meter or two thick, cropped out in a gully (locality 4) on the northeast flank of the volcano upslope from Timberline Viewpoint. The relation of these flows to the one that extends downslope to the North Fork is not known, but all are younger than tephra of layer 
$\mathrm{Bu}$ and are older than a pyroclastic-flow deposit of Sugar Bowl age (p. 65).

A similar succession of olivine basalt lava flows forms a waterfall along Smith Creek (locality 7) about $1 \mathrm{~km}$ east of Windy Pass. Each flow is 2-4 m thick and has a rubbly top. At least one flow moved farther down the Smith Creek valley; before 1980 it cropped out in the bed of Smith Creek near a logging road (locality 5). Basalt flows also overlie the eroded surface of pyroclastic-flow deposits of Pine Creek age along upper Smith Creek about $0.3 \mathrm{~km}$ south-southwest of Windy Pass. A lens of tephra set B that includes layer Bu is preserved at one place beneath the lava flows (D. R. Mullineaux, oral commun., 1977).

PYROCLASTIC-SURGE DEPOSIT IN APE CANYON

A pyroclastic-surge deposit of Castle Creek age that lies above tephra layer $\mathrm{Bo}$ and below layer $\mathrm{Bi}$ was recognized at several places on the south side of Ape Canyon. In one cut along a logging road (locality 18), the deposit is as much as $70 \mathrm{~cm}$ thick and consists of subangular and prismatically jointed clasts of hypersthene-augite dacite as large as $15 \mathrm{~cm}$ in maximum diameter in a matrix of loose, dark-gray lithic ash. One of these clasts had a $\mathrm{SiO}_{2}$ content of 62.5 percent (sample 10, app. A). In another road cut, $2 \mathrm{~km}$ to the east (locality 17), the deposit is $10-70 \mathrm{~cm}$ thick and contains similar clasts as large as $6 \times 7 \times 9 \mathrm{~cm}$. At that locality, the deposit is $60 \mathrm{~m}$ above the floor of Ape Canyon, and in a nearby outcrop, it is as much as $75 \mathrm{~m}$ higher than the canyon floor. In August 1983, the pyroclastic-surge deposit was also seen in the face of a low terrace on the south side of Ape Canyon Creek near the mouth of the canyon. There the deposit is lenticular and as much as $15 \mathrm{~cm}$ thick; it contains clasts of prismatically jointed dacite as large as $5 \times 5 \times 9 \mathrm{~cm}$. The pyroclastic-surge deposit is conformably overlain by a lenticular lahar as much as $55 \mathrm{~cm}$ thick that contains clasts as large as $30 \mathrm{~cm}$ in maximum diameter. The lahar is heterolithologic and includes clasts of hypersthene-hornblende pumice probably derived from tephra set $P$.

When, in the early 1970's, I first noted the pyroclastic-surge deposits on the canyon wall, I thought that they might be a thin, fine-grained facies of thicker and coarser pyroclastic-flow deposits on or near the canyon floor. The recent discovery of a thin, fine-grained deposit near the canyon floor, however, suggests that all these deposits were formed by a pyroclastic surge that extended down the canyon, momentarily filling it to a depth of at least $75 \mathrm{~m}$.

\section{DOME ON THE EAST SIDE OF THE VOLCANO}

A dome that may have been extruded during the Castle Creek eruptive period forms Dog's Head, high on the northeast side of the volcano (pl. 1). The rock of the dome is hypersthene-hornblende dacite (C. A. Hopson, written commun., 1971). The dome is overlain by basalt flows and may have been formed during the episode of dacitic volcanism in Castle Creek time.

LAHARS AND LAVA FLOWS ON THE
SOUTHEAST SIDE OF THE VOLCANO

A succession of lahars interbedded with tephra layers of set B is exposed in the walls of the Pine Creek canyon at locality 28 (measured section 13) (fig. 33). Rock fragments in the lahars are chiefly of pyroxene andesite. According to Hoblitt $(1978$, p. 73-82), clasts in the second lahar above the base of the succession have random directions of TRM, so he concluded that the deposit was cold when it came to rest. The lahars crop out along the top of the canyon walls for about $1.8 \mathrm{~km}$ downstream from the measured section and are intermittently exposed farther downstream within the canyon. At locality 35, for example, two lahars of Castle Creek age overlie deposits of Pine Creek age and form a terrace whose top is about $14 \mathrm{~m}$ above Pine Creek. The maximum downvalley extent of these lahars is not known.

As many as five lahars of Castle Creek age were noted locally in the canyon walls of East Fork Pine Creek, where they are 0.3-3 m thick.

A broad southeast-sloping surface west of Pine Creek, north of Forest Road 83 and east of June Lake, is underlain by deposits of Pine Creek age, which are locally capped by thin, poorly exposed lahars of Castle Creek age and more widespread lahars of Kalama age. The Pine Creek and Castle Creek deposits are overlapped near the base of the volcano by andesite lava flows of Kalama age (p. 76).

\section{Measured section 13}

(Location-east valley wall of Pine Creek at locality 28 in the NW1/4 sec. 29, T. 8 N., R. 6 E. TRM determined by R. P. Hoblitt from progressive thermal demagnetization of clasts in the deposit]

Deposits of Kalama age:

$$
\text { Thickness }
$$
(meters)

13. Lahar: subangular and subrounded fragments of light-gray dacite from summit dome in gray sand matrix; lenticular. As much as

12. Tephra of set $\mathrm{X}$ : horizontally bedded black and gray ash

11. Tephra of set $W$ : ash and lapilli of white hypersthene-and hornblende-bearing pumice Deposit of unknown age:

10. Fine and very fine crossbedded sand of fluvial origin 


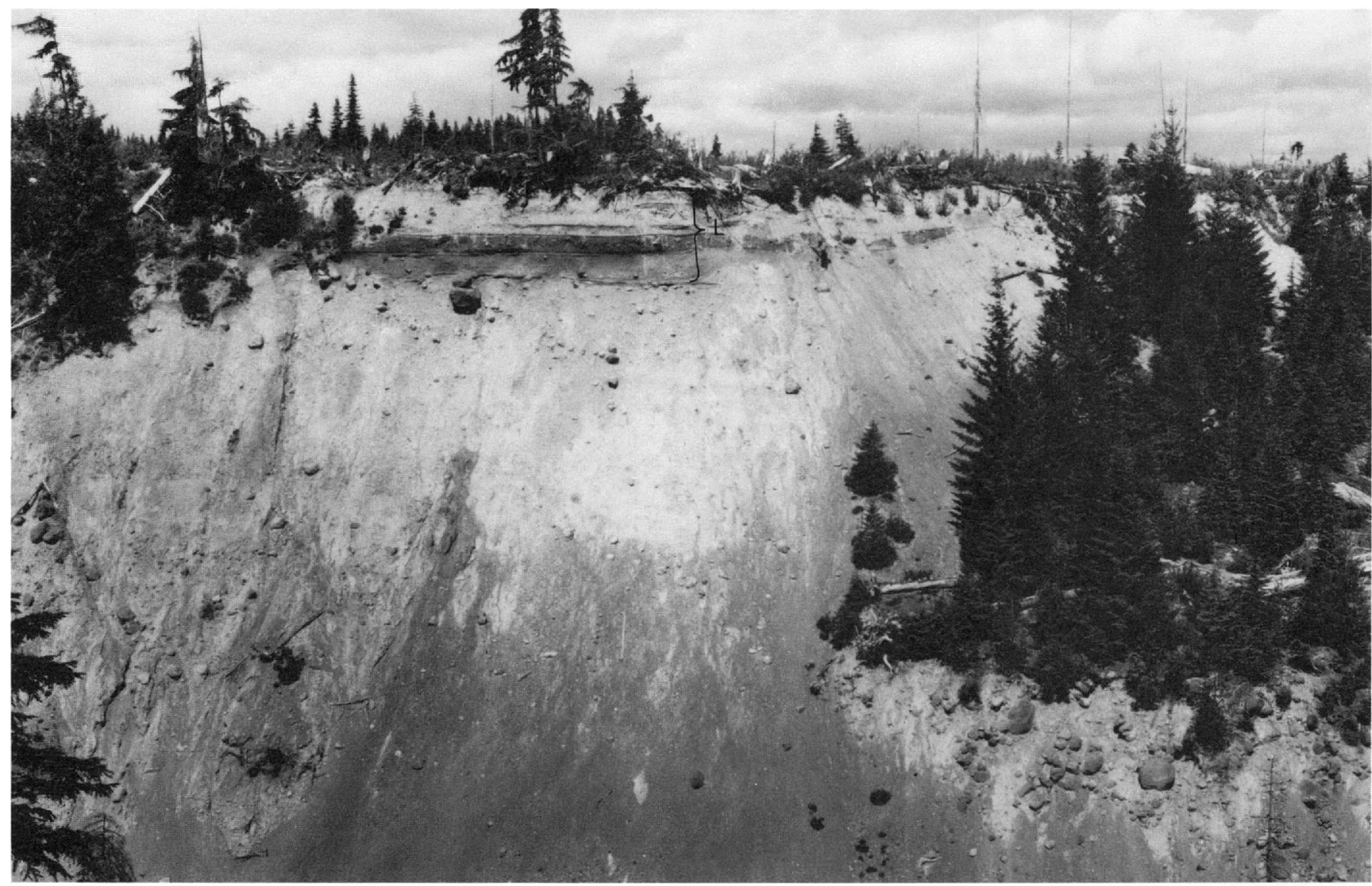

Figure 33.-Lahars of Castle Creek age (L) overlying a pyroclastic-flow deposit of Pine Creek age in the east bank of Pine Creek at measured section 13 (locality 28). The largest boulder just beneath the lahars is about $1 \mathrm{~m}$ in diameter.

Deposits of Castle Creek age:

9. Tephra of layer Bu: dark-brown olivine-bearing ash and lapilli

8. Four lahars: contain clasts of andesite and dacite; lenticular; interbedded with fine sand and silt

7. Lahar: subangular and subrounded fragments of andesite, mostly less than $3 \mathrm{~cm}$ in diameter, in matrix of gray sand and granule gravel

6. Tephra of layer Bo: brownish-black layers of ash and lapilli that contain olivine and augite or hypersthene, olivine, and augite

5. Lahar: subangular and subrounded fragments of andesite as much as $1 \mathrm{~m}$ in diameter in matrix of gray to reddish-brown sand; lenticular; fragments have random directions of TRM. As much as

4. Tephra of layer Bo: brownish-black ash that contains hypersthene, olivine, and augite

3. Lahar: chiefly medium to very coarse brown sand and granules; contains scattered fragments of andesite and dacite as much as $20 \mathrm{~cm}$ in diameter; lenticular. As much as

2. Tephra of layer Bo: fine ash, brown; scattered scoria lapilli at base contain hypersthene, olivine, and augite
Deposit of Pine Creek age:

1. Pyroclastic-flow deposit; reddish-gray; locally

$$
\text { humified in upper } 5 \mathrm{~cm}
$$

At the southeast base of the volcano (locality 22) a succession of lahars of Castle Creek age overlies a glacially eroded, pyroxene- and hornblende-bearing andesite or dacite lava flow of probable Cougar age. The basal lahar of the succession is about $60 \mathrm{~cm}$ thick; three other lahars of similar thickness above it are interbedded with tephra layers of set B.

A lava flow of hypersthene-augite-olivine andesite crops out in the bed of the Muddy River at and downstream from the point at which the river is crossed by Forest Road 83. The flow extends a little more than $1 \mathrm{~km}$ farther downvalley and ends near a second waterfall in the southeast corner of section 17 . Neither the base nor top of this lava flow was exposed prior to 1980 . and its stratigraphic position was not precisely known. Floods and lahars formed by the May 18 eruption, however, stripped vegetation from this area and exposed the lava flow in cross section. Tephra of layer Bh was 


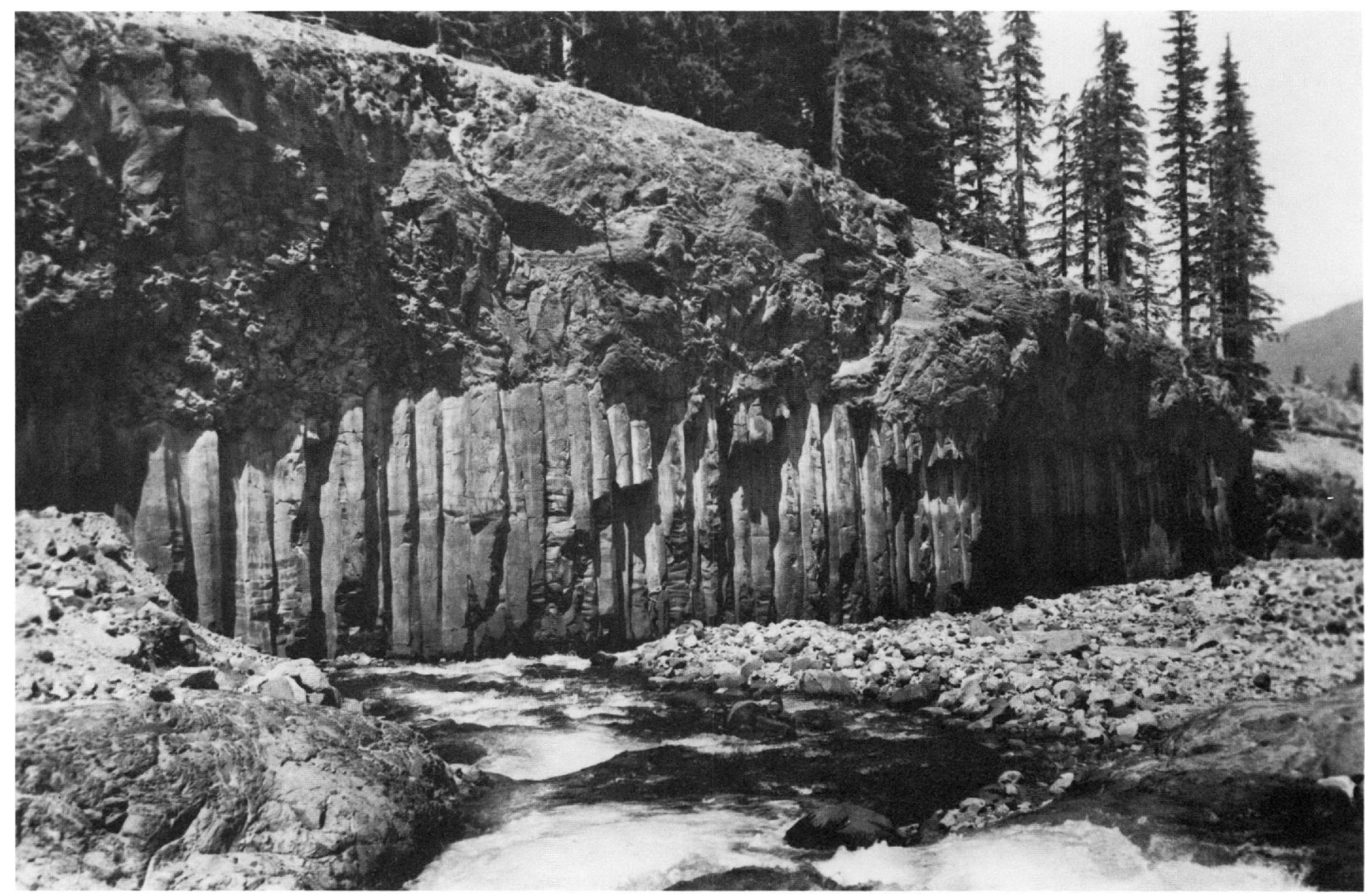

Figure 34. - Columnar jointing in andesite flow of Castle Creek age exposed on the north side of the Muddy River near locality 25. At this outcrop, the lava flow overlies weathered bedrock of Tertiary age. A short distance upstream (to the left in the photograph), the flow overlies tephra of early Castle Creek age and older deposits. The columns are about $4 \mathrm{~m}$ high. Photograph taken in 1982.

found at one place immediately beneath the flow, and at a nearby locality, layer Bo directly overlies the flow; the lava flow thus is of early Castle Creek age. Welldeveloped vertical columnar jointing is a noteworthy feature of the lower part of this andesite flow (fig. 34).

Several other andesite flows of Castle Creek age crop out along the east base of the volcano, but their stratigraphic relations to tephra of set B are not known.

Two lahars of Castle Creek age in the valley of East Fork Swift Creek south of the volcano are both younger than tephra layer Bu but older than set W (Hyde, 1973, p. 65). The older lahar of the two consists of fragments of vesicular basalt in a brown sand matrix and also contains abundant white pumice of sand and pebble size. This lahar is as much as $3 \mathrm{~m}$ thick and mantles the valley sides to a height of about $30 \mathrm{~m}$ (height mistakenly stated as $100 \mathrm{~m}$ by Hyde, 1973, p. 65). This vertical distribution indicates that the lahar was temporarily at least $30 \mathrm{~m}$ deep when it moved down the East Fork valley; however, the lack of a continuous fill indicates that most of the lahar drained downvalley before it solidified.
DEPOSITS IN THE KALAMA RIVER VALLEY

Deposits of Castle Creek age are intermittently exposed along the Kalama River valley downstream from Kalama Falls. I did not examine that area in detail and, in most places, did not differentiate Castle Creek deposits from those of other eruptive periods.

About $35 \mathrm{~km}$ downvalley from the base of the volcano (locality 65), a roadcut in the south face of a terrace exposes a succession of lahars and fluvial deposits (measured section 7). The uppermost lahar is at the top of the terrace and is about $2 \mathrm{~m}$ thick; it overlies lenticular gravel as much as $15 \mathrm{~cm}$ thick that consists chiefly of pumice. A sample of charcoal from the basal part of the gravel had a radiocarbon age of $2,200 \pm 60$ years (W-2436); thus, this deposit and the overlying lahar evidently were formed during the Castle Creek eruptive period. The gravel seems to be a fluvial deposit, and the pumice and charcoal in it may have been derived from a pumiceous pyroclastic flow at the volcano. The terrace is about $20 \mathrm{~m}$ above the Kalama River, which 
indicates that the lahar of Castle Creek age temporarily filled the valley to that depth.

LAVA FLOWS ON THE SOUTH AND SOUTHWEST SIDES OF THE VOLCANO

The longest lava flows at Mount St. Helens were erupted on the southwest flank of the volcano during the Castle Creek eruptive period. The Cave Basalt flow extended southward down a shallow valley cut into pyroclastic-flow deposits and lahars of Swift Creek age. The basalt did not spread eastward and spill into the much deeper valley of West Fork Swift Creek, but flowed southward at a relatively high altitude until it reached the Lewis River valley, where it cascaded down the north side of that valley just west of the site of Swift Dam through a vertical distance of about $125 \mathrm{~m}$. General features of this lava flow and the tubes within it are described by Greeley and Hyde (1972).

A similar and evidently contemporaneous basalt flow extends down the Kalama River valley to a point about $0.8 \mathrm{~km}$ beyond Kalama Falls (Hyde, 1970, p. 7). Drill holes beneath Merrill Lake indicate that the flow is 18-40 m thick. Outcrops of the basalt in the Kalama River valley north of Merrill Lake show the flow to be more than $18 \mathrm{~m}$ thick, but they do not expose its base. Some of the thicknesses of the flow in the Kalama River valley that were reported by Hyde may include an underlying pyroxene andesite flow recognized by C. A. Hopson (unpub. map, 1977).

Prior to 1980 the age of the Cave Basalt was known only from radiocarbon dates on charcoal samples taken from the base of the lava flow at two localities. These samples were dated as $1,860 \pm 70(\mathrm{~W}-2277)$ and $1,925 \pm 95$ (GX-1673) (Greeley and Hyde, 1972, p. 2399-2400). On the basis of these dates, the lava flow was believed to have occurred just before the deposition of tephra layer $\mathrm{Bi}$, which consists of dacite and is bracketed by radiocarbon dates of $1,780 \pm 60(\mathrm{~W}-2924)$ and $1,850 \pm 60$ (W-2925) (Mullineaux and Crandell, 1981). The stratigraphic relation of the Cave Basalt to the various layers of tephra set $B$ was not known until the summer of 1981, when James Nieland, U.S. Forest Service, directed me to a new exposure in the NE1/4 sec. 31, T. 8 N., R. 5 E. (locality 52). Floodwaters associated with the May 18,1980 , eruption and subsequent runoff have cut a small gully there near the west edge of the Cave Basalt lava flow. The flow can be seen in the walls of this gully overlying tephra of layers $\mathrm{Bo}$ and $\mathrm{Bu}$, as well as older tephra and a pyroclastic-flow deposit of Swift Creek age. Thus, the Cave Basalt evidently was erupted at or near the end of the Castle Creek eruptive period, at about the same time that smaller basalt flows moved down other sides of the volcano.
NATURE AND AGE OF VOLCANISM

The Castle Creek eruptive period marked a change in the eruptive style of Mount St. Helens, when the repeated dacitic eruptions that had characterized Smith Creek and Pine Creek time were followed by andesitic volcanism that produced air-fall tephra and a lava flow. Renewed dacitic volcanism then resulted in air-fall tephra, pyroclastic flows, and perhaps a dome, but eruptions later in the period reverted to andesitic; and the period ended with the eruption of voluminous basalt flows. The total volume of tephra erupted during Castle Creek time may have been less than that of any previous eruptive period.

During an early part of Castle Creek time, successive explosive eruptions produced parts of tephra layer Bo at about the same time that lahars of andesitic rock debris moved down the southeast side of the volcano, resulting in interbedding of the two kinds of deposits. The length of time represented by this eruptive activity may have been on the order of days or weeks rather than years.

The end of Castle Creek time has not been closely determined. A radiocarbon limiting date of 1,620 \pm 50 years (W-2990) on a sample from a horizon above tephra of layer Bu suggests that the period ended at about that time, but the stratigraphic relation of the post-Bu basalt flows to the radiocarbon sample horizon is not known.

The distribution of basalt and andesite flows indicates that Mount St. Helens developed into a stratovolcano during Castle Creek time and began to assume its pre-1980 shape. The presence of andesite flows of Castle Creek age as high as about $150 \mathrm{~m}$ below the summit of the pre-1980 volcano indicates that the volcano became almost as high during Castle Creek time as it was before the 1980 eruptions.

\section{SUGAR BOWL ERUPTIVE PERIOD}

The Sugar Bowl eruptive period occurred about midway between the Castle Creek and Kalama eruptive periods. The principal product of this period was the Sugar Bowl dome (locality 3), which is a nearly circular protrusion of hypersthene-hornblende dacite, about $800 \mathrm{~m}$ in diameter, on the north flank of Mount St. Helens $^{5}$. The dacite of the dome evidently flowed a short distance downslope during its extrusion; before the 1980 eruptions it could be seen overlying basalt lava flows in a ravine west of Sugar Bowl (D. R. Mullineaux, oral commun., 1975).

\footnotetext{
${ }^{5}$ Verhoogen (1937) identified the dome on his geologic sketch map of Mount St. Helens and called it the Sugar Cone plug, he noted that the mass has horizontal flow structures instead of the vertical or fan-shaped flow structures that are more typical of plugs and domes.
} 


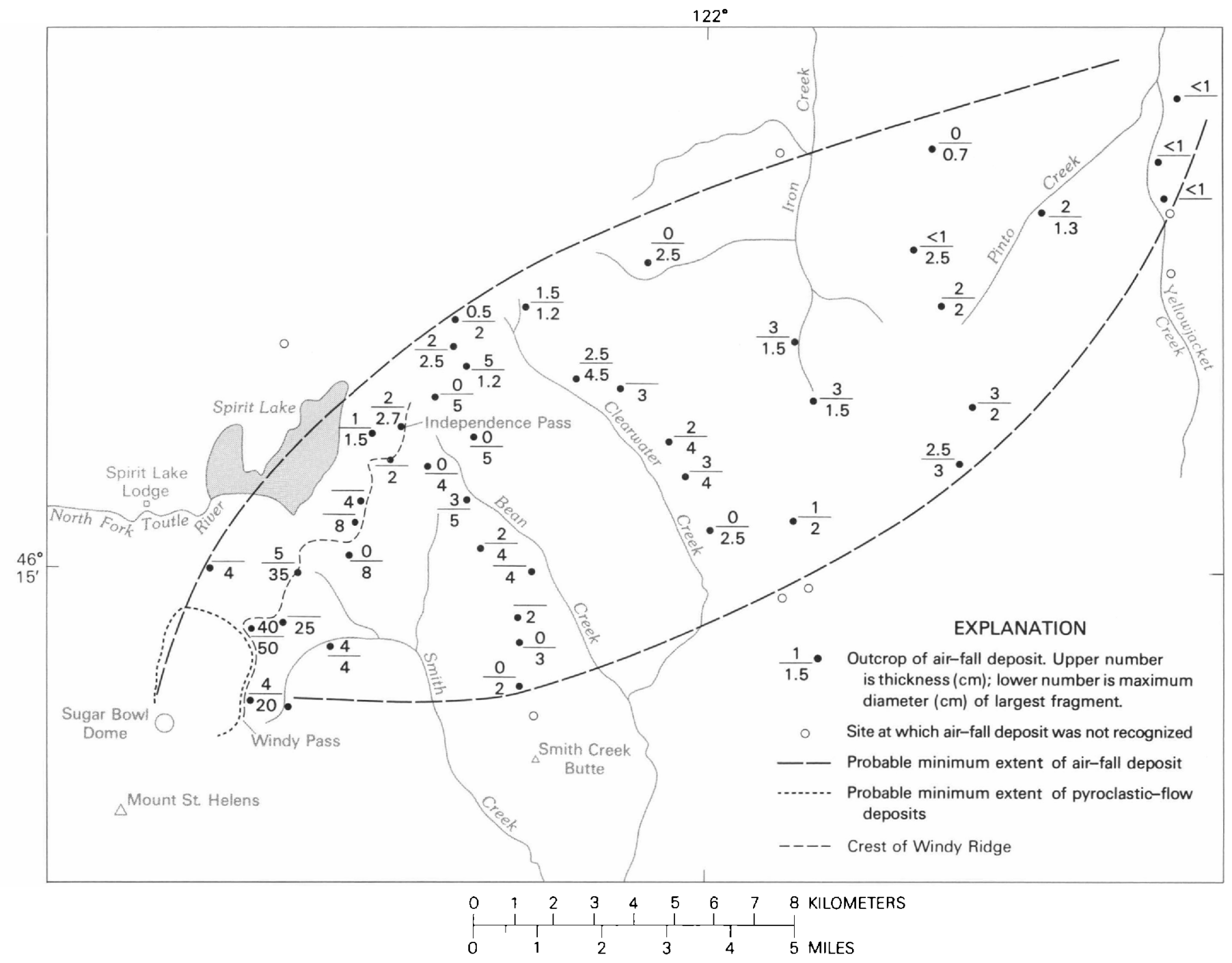

FIGURE 35.-Sketch map showing inferred distribution of air-fall tephra and pyroclastic-flow deposits of Sugar Bowl age.

The extrusion of the dome was accompanied by explosions which produced fragmental deposits; the description of these deposits that follows has been condensed from a report by Crandell and Hoblitt (1986).

\section{FRAGMENTAL DEPOSITS ASSOCIATED WITH THE SUGAR BOWL DOME}

Fragmental deposits produced by explosions during the extrusion of the Sugar Bowl dome include air-fall ash, lapilli, and blocks, as well as pyroclastic-flow deposits and lahars. All the fragmental deposits consist wholly or mostly of hypersthene-hornblende dacite like that of the Sugar Bowl dome. The fragmental deposits stratigraphically overlie tephra set B and underlie tephra set $W$, formed about 500 years ago (Yamaguchi, 1983). A charcoal sample obtained from the air-fall deposits of Sugar Bowl age had a radiocarbon age of 1,150 \pm 60 years (W-2993) (Crandell and others, 1981), and charcoal from a pyroclastic-flow deposit had an age of $1,200 \pm 200$ years (W-5343).

\section{AIR-FALL TEPHRA}

Air-fall deposits produced by a laterally directed explosion at the site of the Sugar Bowl dome include two principal components: 1) debris thrown on ballistic trajectories by the explosion, and 2) ash suspended in the blast cloud and subsequently transported eastward by winds. 
Ballistic Fragments

Rock debris that was thrown into place along ballistic trajectories can be seen in road cuts and natural exposures along a ridge that trends northward from Windy Pass to Independence Pass; this ridge is informally referred to here as Windy Ridge (fig. 35).

The debris includes breadcrusted and prismatically jointed blocks of hypersthene-hornblende dacite as well as a small proportion of fragments of nonvesicular hornblende dacite that contains cummingtonite and biotite. The breadcrusted surfaces of the hypersthenehornblende dacite blocks indicate a juvenile origin, and these blocks are thought to have been derived from an early Sugar Bowl dome. When the blocks are removed from an outcrop, most break apart along joints that were formed as the blocks cooled. The blocks, some of which are as large as $50 \mathrm{~cm}$ in maximum diameter (MD), generally are accompanied by a lenticular layer of slightly vesicular ash and lapilli a few centimeters to $40 \mathrm{~cm}$ thick. For example, on the east side of the ridge near Windy Pass (fig. 35), the ash layer is about $4 \mathrm{~cm}$ thick and the associated breadcrusted blocks are as large as $14 \times 15 \times 20 \mathrm{~cm}$. A block with an MD of $35 \mathrm{~cm}$ was noted at a point $4.5 \mathrm{~km}$ northeast of Sugar Bowl, where the ash is no more than $5 \mathrm{~cm}$ thick. The presence of blocks within the ash layer at many places suggests that the ash and blocks were deposited simultaneously.

At some places along Windy Ridge, dacite blocks with MDs of as much as $30 \mathrm{~cm}$ lie in depressions in the underlying ash of tephra set $B$, which suggests that the blocks fell into place on ballistic trajectories.

The rock fragments decrease in diameter away from the volcano. At a site 6-7 km northeast of Sugar Bowl, the MD of the largest fragment noted is $8 \mathrm{~cm}$, and those having MDs of $5 \mathrm{~cm}$ extend northeastward as far as about $10 \mathrm{~km}$ from Sugar Bowl. The outward limit of ballistic material is arbitrarily based on the presence of fragments $4 \mathrm{~cm}$ or larger in MD. The sector defined by such fragments covers an $\operatorname{arc}$ of $30^{\circ}$ and includes an area of about $50 \mathrm{~km}^{2}$.

In addition to the large proportion of dacite fragments derived from the Sugar Bowl dome, the deposit along Windy Ridge contains a small proportion of nonvesicular dacite that contains hornblende, cummingtonite, and biotite. Blocks of this nonvesicular rock have MDs of as much as $12 \mathrm{~cm}$ at a point $6 \mathrm{~km}$ northeast of Sugar Bowl (fig. 35). These blocks are mineralogically similar to those in pyroclastic-flow deposits and tephra formed during the Ape Canyon eruptive period. The presence of both Sugar Bowl and Ape Canyon rocks in the ballistic deposit along Windy Ridge suggests that the Sugar Bowl magma intruded rocks of Ape Canyon age beneath the north flank of the volcano.
Wind-Transported TEPHRA

Ash accompanied by scattered angular lapilli of light gray hypersthene-hornblende dacite extends at least $30 \mathrm{~km}$ northeastward from Mount St. Helens in an elliptical lobe (fig. 35). The deposit typically is of variable thickness and is represented in some outcrops only by scattered lapilli of dacite from the Sugar Bowl dome. The layer is as much as $3 \mathrm{~cm}$ thick east of Clearwater Creek and is only a few millimeters thick east of Yellowjacket Creek, at a distance of about $30 \mathrm{~km}$ from Sugar Bowl. In addition to the $50 \mathrm{~km}^{2}$ area in which there are fragments $4 \mathrm{~cm}$ or larger in MD, the wind-borne ash and accompanying smaller lapilli fell across an area of at least $200 \mathrm{~km}^{2}$.

\section{PYROCLASTIC-FLOW DEPOSITS}

Pyroclastic-flow deposits consisting of ash, lapilli, and blocks of dacite like that of the Sugar Bowl dome, and in the same stratigraphic position as the air-fall deposits, are exposed at several places on the northeast flank of Mount St. Helens. Nowhere, however, have pyroclastic-flow deposits been seen in contact with airfall deposits. At a site near the western base of Windy Ridge, about $2.2 \mathrm{~km}$ northeast of Sugar Bowl, post-1980 erosion has exposed flowage deposits through a northsouth distance of about $50 \mathrm{~m}$ (fig. 36). The deposits are $45-100 \mathrm{~cm}$ thick and consist mostly of unstratified, poorly sorted gray ash and small lapilli, but include breadcrusted blocks of juvenile dacite as large as $16 \mathrm{~cm}$ in maximum diameter. The deposits appear to be a single unit; however, rock types in samples from the lower and upper parts of the deposits indicate that two units are present even though a contact between them is not discernible. Rock fragments from the lower part consist entirely of dacite from Sugar Bowl. In the upper part of the deposit, 15 percent of the rock fragments consist of dacite like that of Ape Canyon age and similar to that in the ballistic air-fall deposits on Windy Ridge. The lithologic similarity of the upper part of the pyroclastic flow deposits to the ballistic air-fall deposit on Windy Ridge suggests that both were formed by the same event.

Wood fragments and twigs are abundant in the flowage deposits, and although some fragments are only partly charred, most are completely carbonized. The lower part of the deposits contains, in addition, abundant conifer needles and clumps of needles, some of which are carbonized.

The lower unit contains irregular masses of oxidized ash derived from the underlying soil developed on tephra set B. Some masses form lenses that project 


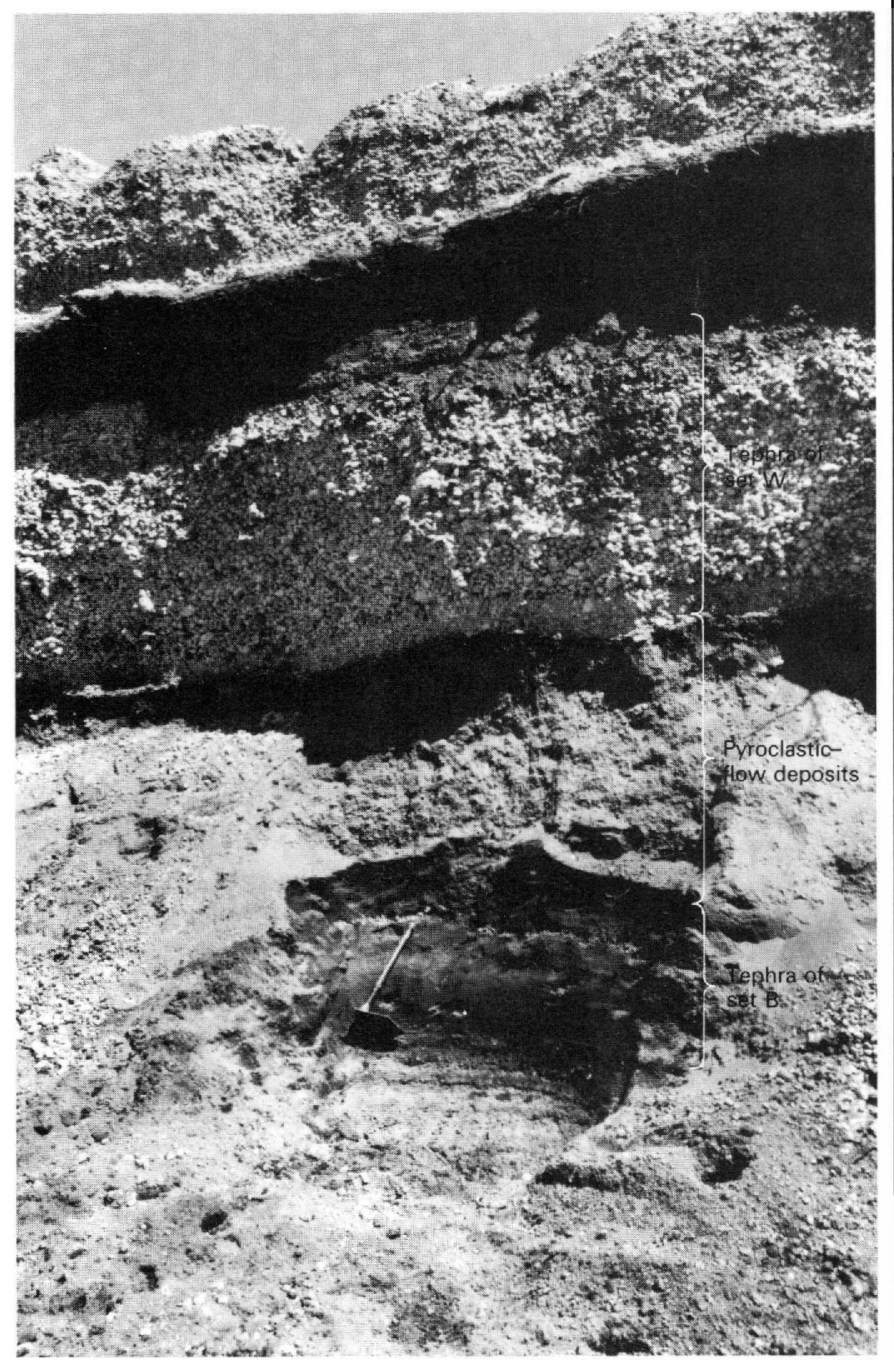

FIGURE 36.-Pyroclastic-flow deposits that resulted from lateral blasts at the site of Sugar Bowl dome. Outcrop along a gully near the intersection of Forest Road 99 and the former State Highway 504 on the north side of the volcano. Photograph taken in July 1981.

upward from the soil into the lower part of the flowage deposit. In addition, lenses of the lower unit project downward into the soil. The base and top of the flowage deposits, however, are generally planar despite these local irregularities. The mixing of soil with the lower unit, as well as the flat top of the upper unit, seem to indicate that all the debris flowed into place. This interpretation is consistent with the massive and poorly sorted character of the deposits.

Zones of openwork are common in the flowage deposits. Some zones are vertical and as much as $10 \mathrm{~cm}$ wide and $50 \mathrm{~cm}$ long, and others dip at angles ranging from nearly vertical to nearly horizontal. In addition, the ash and lapilli matrix of the deposit has an overall openwork texture and includes little fine ash.
Before the 1980 eruptions, a pyroclastic-flow deposit was exposed in the side of a gully about $1 \mathrm{~km}$ directly downslope from the Sugar Bowl dome. The deposit was $1.4 \mathrm{~m}$ thick and contained breadcrusted and prismatically jointed dacite blocks as large as $70 \mathrm{~cm}$ in diameter. A similar deposit was noted on the northeast flank of the volcano $0.7 \mathrm{~km}$ northeast of Sugar Bowl. This deposit was 2-3 $\mathrm{m}$ thick and contained breadcrusted blocks of both vesicular and nonvesicular Sugar Bowl dacite as much as $2 \mathrm{~m}$ in diameter. The deposit had a reddish-gray zone in its upper part that is indicative of emplacement at a high temperature.

Two superposed pyroclastic-flow deposits with a combined thickness of about $1 \mathrm{~m}$ are now exposed in the walls of a gully about $1 \mathrm{~km}$ north of Sugar Bowl. The lower of the two has a somewhat higher proportion of ash-sized material than the upper. Fifty rock fragments taken from each unit were identified as follows. The lower unit contains 38 percent dacite from Sugar Bowl and 6 percent dacite of Ape Canyon age; the remaining fragments are andesite of pre-Sugar Bowl age. The upper half contains about 70 percent dacite from Sugar Bowl and 14 percent dacite of Ape Canyon age; the remaining fragments are from rocks of pre-Sugar Bowl age. This difference in proportions of rock types suggests that the deposits were formed by two pyroclastic flows, both of which are lithologically similar to the ballistic air-fall deposits on Windy Ridge.

\section{LAHARS}

Before the 1980 eruptions, three superposed lahars of Sugar Bowl age cropped out on the south bank of the North Fork Toutle River near Spirit Lake Lodge (locality 1) (units 7, 8, and 9, measured section 14). Each lahar was less than $1 \mathrm{~m}$ thick and contained abundant breadcrusted blocks of Sugar Bowl dacite in a sand matrix. Most clasts in the lower two lahars were no more than $5 \mathrm{~cm}$ in diameter, but the uppermost lahar contained dacite clasts as large as $30 \mathrm{~cm}$ in diameter. The stratigraphic relation of the lahars to the other Sugar Bowl fragmental deposits is not known.

\section{Measured section 14}

[Location-south bark of North Fork Toutle River at locality 1, in the NE1/4 sec. 16, T. 9 N., R. 5 E. This outcrop was buried by the debris avalanche of May 18, 1980]

Deposits of Kalama age:

Thickness (meters)

16. Breadcrusted blocks as much as $1.5 \mathrm{~m}$ in diameter of dark-gray to black scoriaceous pyroxene andesite in black ash matrix; basal $20-30 \mathrm{~cm}$ is mostly less than $5 \mathrm{~cm}$ in diameter; contains scattered pumice lapilli in upper $2 \mathrm{~m}$ and abundant wood fragments, most of which are carbonized throughout; one sample yielded a radiocarbon date of $460 \pm 60$ years $(W-2874)$ and another a date of $275 \pm 60$ years $(W-3991)$ 
Deposits of Kalama age-Continued

15. Sand, dark gray and black; contains scattered pumice lapilli and wood fragments; lenticular. As much as

14. Sand and granule gravel; lenticular. As much as

13. Lahar: mixture of medium to coarse sand and pumice lapilli derived from tephra set $W$, and rock fragments mostly less than $3 \mathrm{~cm}$ in diameter

12. Lahar, as above

11. Lahar, chiefly pumice fragments $5 \mathrm{~cm}$ or less in diameter in gray sand matrix

10. Tephra of set $W$ : lenses and layers of pumice lapilli and blocks as large as $7 \times 12 \times 15 \mathrm{~cm}$ in matrix of fine ash

Deposits of Sugar Bowl age:

9. Lahar: breadcrusted blocks of light-gray dacite as much as $30 \mathrm{~cm}$ in diameter in matrix of grayishbrown fine and medium sand; contains many small charcoal fragments; duff zone in upper $3 \mathrm{~cm}$ (soil)

8. Lahar: unsorted mixture of sand and rock fragments; includes small breadcrusted fragments of light-gray dacite as well as basalt and andesite

7. Lahar: rock fragments mostly less than $5 \mathrm{~cm}$ in diameter in brownish-gray sand matrix; contains abundant fragments of light-gray hypersthenehornblende dacite $\ldots \ldots \ldots \ldots \ldots \ldots \ldots$

Deposit of Castle Creek(?) age:

6. Lahar(?): rock fragments as much as $50 \mathrm{~cm}$ in diameter in brownish-gray sand matrix

Deposits of Pine Creek age:

5. Silt and fine to coarse sand; purplish-gray; includes layers of ash and small pumice lapilli of tephra set $P$; includes several thin layers of organic matter near top

Deposits of Smith Creek age:

4. Gravel, consists chiefly of pumice lapilli derived from tephra set $Y$

3. Silt and fine sand, gray

2. Sand and pumice lapilli of tephra set $Y$

1. Silt and fine sand, grayish-brown, at river level
15

.15

.4

.4

$.25-.4$

.3

.4

.6

\section{ORIGIN OF THE SUGAR BOWL FRAGMENTAL DEPOSITS}

The large breadcrusted dacite blocks accompanied by lenticular deposits of ash along the crest and east side of Windy Ridge were regarded as products of a northeast-directed lateral blast by Crandell and Mullineaux (1978) because the size and distribution of the blocks suggested that they were thrown on ballistic trajectories to their present locations. Pyroclastic-flow deposits and lahars in the same general stratigraphic position as the dacite blocks were thought to have resulted directly or indirectly from the blast (Mullineaux and Crandell, 1981).

The stratigraphy, character, and distribution of the fragmental deposits suggest that they originated from at least two explosions at the site of Sugar Bowl. The first explosion, which may have occurred soon after the initial extrusion of the Sugar Bowl dome, threw debris from the dome northeastward. After falling onto the land surface, some of this rock debris subsequently flowed downslope and is represented by the lower part of the pyroclastic-flow deposits along the west base of Windy Ridge. Rock debris from this explosion has not been recognized on Windy Ridge. A second, more energetic, explosion threw dacite rock debris northeastward across a sector of about $30^{\circ}$, some of which moved downslope to form part of the pyroclastic-flow deposits.

Much of the rock debris derived from the dome was hot, as is indicated by the charred wood in the resulting tephra and pyroclastic-flow deposits, the breadcrusted surfaces of dacite blocks, and the local presence of a reddish gray zone at the top of some of the pyroclastic-flow deposits. The zones of openwork in the pyroclastic-flow deposits probably are gas-escape structures and may have been caused by the incorporation of snow and its conversion to steam. The inclusion of wood that is only partly charred and the local presence of conifer needles that are not carbonized suggest that parts of the pyroclastic flows either were not at a high temperature or were quenched before charring could occur.

The distribution of the air-fall ash that extends east northeastward from the volcano indicates transportation by wind. The ash probably represents the finegrained component of the second and perhaps also the first lateral blast. No stratigraphic evidence was found that either explosion was preceded or accompanied by a vertical eruption of pumiceous tephra.

The presence in the ballistic air-fall tephra of rock fragments that were derived from eruptive products of Ape Canyon age raises the question of how this rock could have been incorporated in the Sugar Bowl deposits without the inclusion of substantial amounts of other rock debris of pre-Sugar Bowl age. I suggest that the first explosion occurred after an embryonic Sugar Bowl dome had already been extruded and that the explosion threw out only dome rock. The second explosion, which may have quickly followed the first, could have occurred at the base of the dome and involved rock of Ape Canyon age as well as that of the dome. Subsequent extrusion of the dome could have covered remnants of the Ape Canyon rocks.

\section{EAST DOME}

East dome is a small protrusion of hypersthenehornblende dacite at the east base of Mount St. Helens, $2.5 \mathrm{~km}$ southeast of the Sugar Bowl dome. The oldest tephra on top of it is part of set $W$. The absence of set $B$ tephra indicates that the dome is younger, because this area is well within the distribution of the tephra 


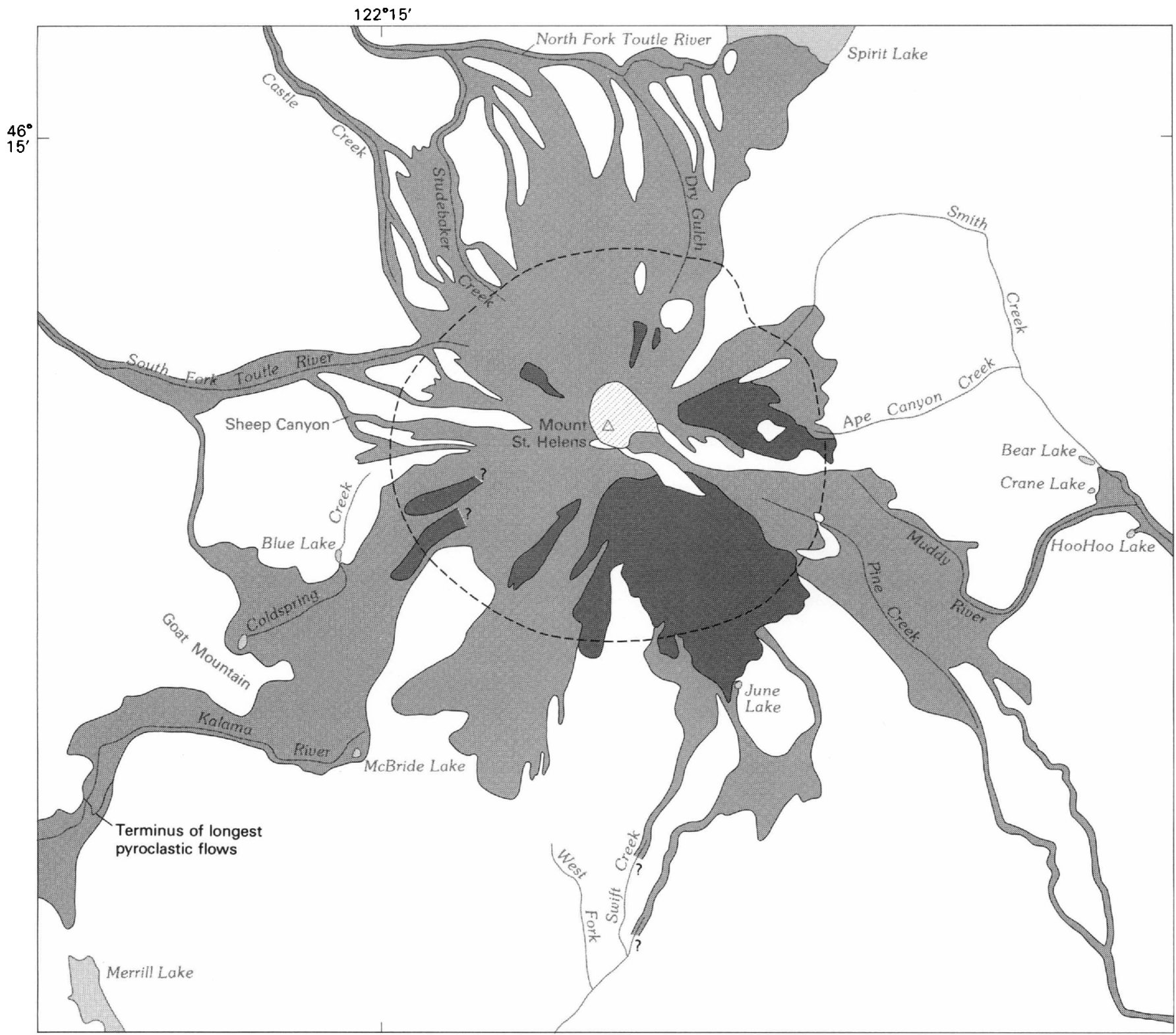

0 5 KILOMETERS

EXPLANATION

Pyroclastic-flow

deposits, lahars,

and local fluvial

deposits

Lava flows

Dome

FIGUne 37.-Sketch map showing inferred original extent of lava flows, pyroclastic-flow deposits, dome, lahars, and fluvial deposits formed during the Kalama eruptive period at Mount St. Helens. Based chiefly on unpublished geologic map by C. A. Hopson. Dashed line shows the base of the volcano. 
(D. R. Mullineaux, oral commun., 1979). Although the dome is tentatively assigned to the Sugar Bowl eruptive period, it could have been formed any time between the deposition of tephra sets $B$ and $W$, a time span of at least 1,000 years. No fragmental deposits associated with the formation of the dome were identified.

\section{KALAMA ERUPTIVE PERIOD}

The Kalama eruptive period began in A.D. 1480 and lasted about 100 years. Eruptive events included the formation of dacitic and andesitic tephra, dacite domes, pumiceous and lithic pyroclastic flows, andesite lava flows, and lahars. These eruptions affected every flank of the volcano (fig. 37), and one of them spread tephra across much of northeastern Washington and into Canada (Smith and Okazaki, 1977).

The succession of kinds of eruptive activity during Kalama time seems to be as shown below, but dating of some events is not precise enough to establish their exact chronology or to reveal whether they were separated by many years of dormancy. Determination of the calendar ages of volcanic events is especially difficult for the Kalama eruptive period, principally because events of the last 500 years cannot be closely dated by radiocarbon.

\begin{tabular}{ll}
\hline & $\begin{array}{c}\text { Formation of andesitic pumiceous pyro- } \\
\text { clastic flows } \\
\text { Extrusion of summit dacite dome; forma- } \\
\text { tion of dacitic lithic pyroclastic flows } \\
\text { and lahars }\end{array}$ \\
Formation of andesitic pyroclastic flows \\
and lahars \\
Eruption of andesite lava flows \\
Eruptions of andesitic ash of tephra set X \\
Early Kalama time $\quad$ Extrusion of dacite dome(s); formation of \\
dacitic pyroclastic flows \\
Eruption of dacitic pumice of tephra set W
\end{tabular}

Deposits formed during the Kalama eruptive period are discussed in their inferred order of age from oldest to youngest as determined by stratigraphic relations and radiocarbon dating (table 10).

\section{DEPOSITS OF EARLY KALAMA AGE}

The initial event of the eruptive period was the formation of tephra set W. A recent analysis of annual growth rings of trees in the fallout area of the oldest part of set $W$, layer $W n$, indicates that this tephra was erupted in A.D. 1480 (Yamaguchi, 1982, 1983). Fluvial deposits more than $4 \mathrm{~m}$ thick, consisting almost entirely of pumice ash and lapilli of set $W$, underlay the broad smooth surface that, before the 1980 eruptions, sloped from the volcano northward down to Spirit Lake. Lahars less than a meter thick and of similar lithology were locally interbedded with the fluvial deposits. These deposits partly buried a mature forest, and the subsequent rotting of large trees left many vertical tubes or "tree wells." Lawrence $(1954$, p. 43$)$ attributed the burial of the trees to a "coarse volcanic mudflow or possibly glacier outwash," but there is no evidence that any of these deposits are genetically related to glaciers on Mount St. Helens. From the ages of the trees that survived partial burial, Lawrence concluded that burial occurred sometime before A.D. 1550. The fluvial deposits and lahars derived from tephra set $\mathrm{W}$ probably were formed very soon after the tephra was deposited.

Similar pumiceous fluvial deposits and lahars derived chiefly from tephra of set $\mathrm{W}$ are locally present at the east base of the volcano, north of Ape Canyon Creek.

South of the volcano, a lahar that contains abundant pumice derived from set $W$ crops out along Forest Road 83 near the creek that drains June Lake (locality 41). In addition to pumice lapilli and blocks, the lahar contains andesite boulders as much as $30 \mathrm{~cm}$ in diameter. This lahar is overlain by a lenticular lahar of andesitic rock debris as much as $1.8 \mathrm{~m}$ thick. Some prismatically jointed blocks in this lahar are as large as $70 \mathrm{~cm}$ in maximum diameter. The lahars are overlain by about $1.5 \mathrm{~cm}$ of ash of tephra set $X$ and two more lahars, the lower of which is as much as $60 \mathrm{~cm}$ thick and contains andesite boulders as much as $50 \mathrm{~cm}$ in diameter. The upper lahar is about $80 \mathrm{~cm}$ thick and contains pumice as well as andesite boulders as much as $1.3 \mathrm{~m}$ in diameter. Tephra set $\mathrm{X}$ and the overlying lahars were formed during middle Kalama time.

The Kalama River valley contains pyroclastic-flow and fluvial deposits that probably were formed during and shortly after the eruptions that produced tephra set $W$. The pyroclastic-flow deposits terminate about $3 \mathrm{~km}$ north of Merrill Lake, but fluvial deposits extend farther down the Kalama River valley.

The two longest pyroclastic flows in the Kalama River valley are represented by deposits exposed in the walls of a gravel pit adjacent to Forest Road 81 (locality 63) (fig. 38). The pit is about $0.6 \mathrm{~km}$ from the downvalley terminus of the pyroclastic-flow deposits and about $13.5 \mathrm{~km}$ from the pre-1980 summit of the volcano. The lower deposit at the pit is a mixture of angular and subangular rock fragments as much as $1 \mathrm{~m}$ in diameter in a loose matrix of gray lithic ash. The fragments are chiefly light-gray nonvesicular dacite that contains hypersthene and hornblende, but about 20 percent of 
TABLE 10.-Radiocarbon dates on samples that date or limit the ages of deposits of the Kalama eruptive period [Corrected dates are based on the tree-ring correction curve of Stuiver and Pearson (1986). Dates are in years before 1950. A one-sigma standard deviation is not shown for the corrected dates.]

\begin{tabular}{|c|c|c|c|}
\hline $\begin{array}{c}\text { Radiocarbon } \\
\text { date }\end{array}$ & $\begin{array}{c}\text { Corrected } \\
\text { date }\end{array}$ & $\begin{array}{l}\text { Sample } \\
\text { No. }\end{array}$ & Stratigraphic position and location \\
\hline $275 \pm 60$ & 310 & $W-3991$ & $\begin{array}{l}\text { Charcoal from deposit of a post-W hot lahar } \\
\text { (unit } 16 \text {, measured section } 14 \text { ). South } \\
\text { bank of North Fork Toutle River near } \\
\text { Spirit Lake Lodge, SE1/4NE1/4 sec. } 16 \text {, } \\
\text { T. } 9 \text { N., R. } 5 \text { E. }\end{array}$ \\
\hline $290 \pm 70$ & 315 & $W-3995$ & $\begin{array}{l}\text { Charcoal from upper pyroclastic-flow deposit } \\
\text { of Kalama age. Gravel pit in Kalama River } \\
\text { valley, SEl } / 4 \mathrm{NWl} / 4 \mathrm{sec} .33 \text {, T. } 8 \mathrm{~N} \text {, } \\
\text { R. } 4 \mathrm{E} \text {. }\end{array}$ \\
\hline $350 \pm 60$ & 340 or 440 & $W-3150$ & $\begin{array}{l}\text { Charcoal from pyroclastic-flow deposit that } \\
\text { overlies lahar of rock debris from summit } \\
\text { dome. Cut along road in Castle Creek } \\
\text { valley, NW1/4 sec. } 24 \text {, T. } 9 \mathrm{~N} \text {, } \\
\text { R. } 4 \mathrm{E} \text {. }\end{array}$ \\
\hline $460 \pm 60$ & 515 & W-2874 & $\begin{array}{l}\text { Charcoal from deposit of hot lahar of Kalama } \\
\text { age (same deposit as that represented by } \\
\text { sample } W-3991 \text { ). }\end{array}$ \\
\hline $510 \pm 50$ & 535 & $W-2989$ & $\begin{array}{l}\text { Charcoal from pyroclastic-flow deposit of } \\
\text { Kalama age. Borrow pit at southeast base } \\
\text { of Goat Mountain, NE } 1 / 4 \mathrm{NWl} / 4 \text { sec. } 26 \text {, } \\
\text { T. } 8 \text { N., R. } 4 \text { E. }\end{array}$ \\
\hline $610 \pm 50$ & $\begin{array}{c}570,600 \\
\text { or } 640\end{array}$ & $W-2403$ & $\begin{array}{l}\text { Charcoal from lower pyroclastic-flow } \\
\text { deposit of Kalama age. Same locality as } \\
\text { sample W- } 3995 \text {. }\end{array}$ \\
\hline
\end{tabular}

${ }^{1}$ Date on deposit that resulted from an eruption.

the fragments consist of basalt and hypersthenehornblende pumice in about equal proportions (Hyde, 1973, p. 112). The deposit has an exposed thickness of about $10 \mathrm{~m}$, and nearby outcrops of a basalt lava flow of Castle Creek age suggest that the base of the pyroclastic flow is not far below the floor of the pit.

At times when the walls of the pit are nearly vertical, a crude horizontal stratification can be seen in the part of the lower deposit that is exposed in the north wall of the pit (fig. 38). The stratification consists of alternating zones of material of slightly different textures and shades of gray and seems to be limited to the top few meters of the deposit. The origin of the stratification seems best explained by movement by laminar flow as the pyroclastic flow was coming to rest (p. 4).

Progressive thermal demagnetization was carried out (Hoblitt, 1978; Hoblitt and Kellogg, 1979) on a total of 27 clasts from the lower pyroclastic-flow deposit. Of these, 2 clasts yielded inconclusive results; 13 were emplaced above their maximum blocking temperatures, which ranged from about $400^{\circ} \mathrm{C}$ to $450^{\circ} \mathrm{C}$; and 12 were emplaced below their blocking temperatures, but at $300^{\circ} \mathrm{C}$ or above. These experimentally determined emplacement temperatures, as well as other characteristics, are consistent with and seem to favor a pyroclastic-flow origin of the deposit. 


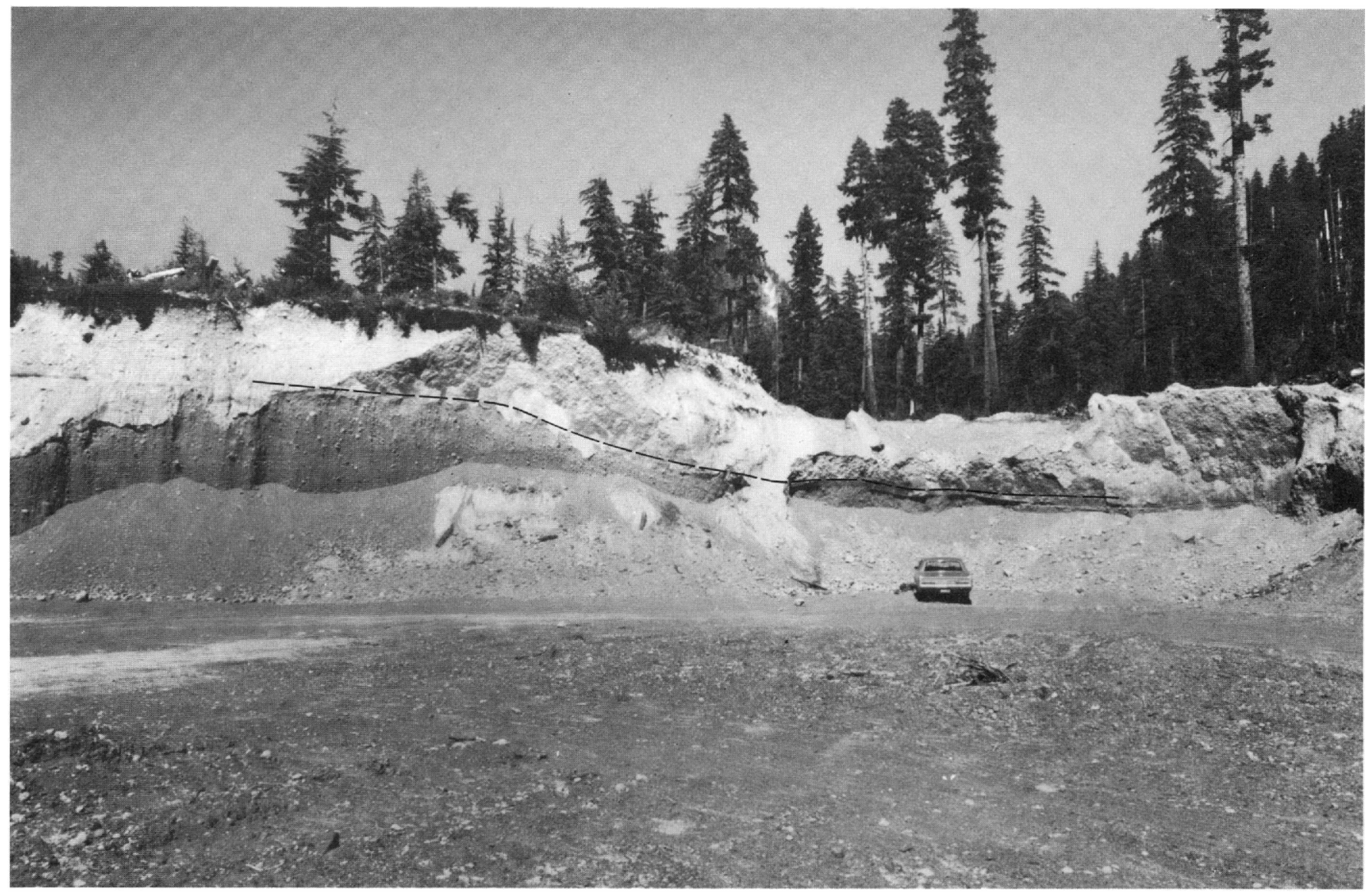

FIGURE 38.-Two pyroclastic-flow deposits of Kalama age exposed in the walls of a gravel pit in the Kalama River valley (locality 63). The upper deposit is compact and contains abundant pumice; lower deposit is loose and contains less pumice. Lower deposit shows faint horizontal banding at the left side of the photograph.

A lenticular layer as much as $15 \mathrm{~cm}$ thick of coarse ash overlies the pyroclastic-flow deposit (fig. 39). This layer has thin planar bedding, and some beds become finer in texture upward. The beds probably were formed by a pyroclastic surge that immediately preceded a second pyroclastic flow.

The upper pyroclastic-flow deposit at the gravel pit contains more fine ash in its matrix than does the lower deposit and is somewhat more coherent. The upper deposit contains nonvesicular light-gray fragments of hypersthene-hornblende dacite as well as abundant lapilli and small blocks of white hypersthene-hornblende pumice that is mineralogically similar to pumice of tephra set W (D. R. Mullineaux, oral commun., 1979). The thickness of the upper deposit is as much as about $5 \mathrm{~m}$, but is variable because of the uneven surface of the underlying pyroclastic-flow deposit. Although the overall color of the upper deposit is light gray, the uppermost 1-2 $\mathrm{m}$ is reddish gray.

The upper pyroclastic-flow deposit contains scattered pumice clasts throughout and also includes horizontal lenses of pumice lapilli and blocks in an ash matrix. These lenses are as much as $1.5 \mathrm{~m}$ thick (fig. 40) and several tens of meters wide in a direction normal to the direction of flow. The matrix of the lenses seems to grade imperceptibly into the matrix of the adjoining material, and no depositional hiatus is visible beyond their ends. Similar lenses were recognized in pyroclasticflow deposits of Pine Creek age at one locality (measured section 6) (Crandell and Mullineaux, 1973, p. 16). The upper deposit exposed at the gravel pit may have been formed by a series of pyroclastic flows, as suggested by Hyde (1973, p. 74-75, 112), but the absence of conspicuous breaks within the deposit suggests that the upper deposit was formed as a single unit. If so, the presence of the horizontal lenses of pumice blocks seems to indicate movement as laminar flow or as flow en masse ("plug flow").

A lens of pumice ash, lapilli, and blocks as much as $1 \mathrm{~m}$ thick forms the top of the upper pyroclastic-flow deposit. The basal contact of this lens is marked by a textural contrast with the finer material below, but the 


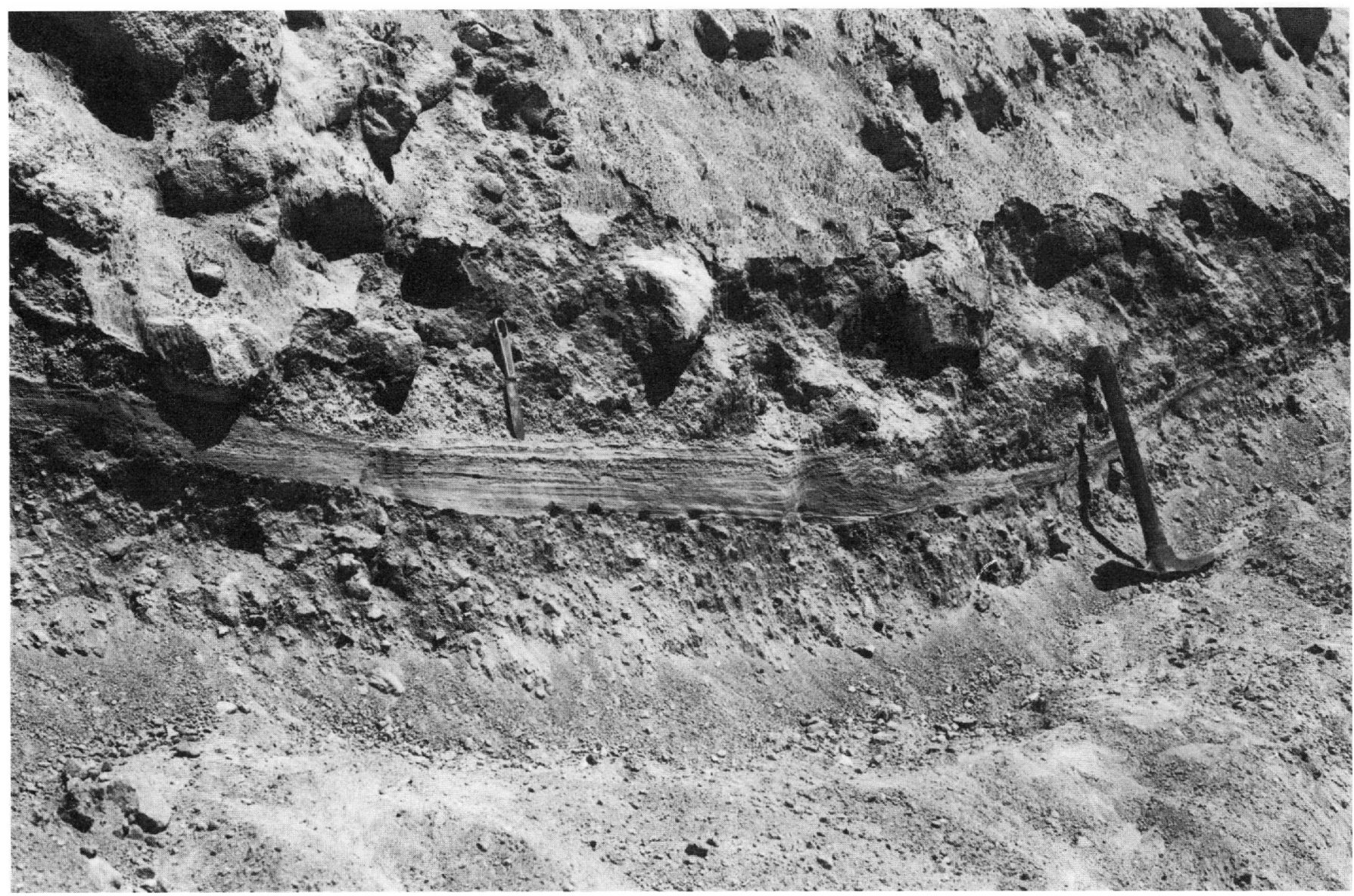

FIGURE 39.-Pyroclastic-surge deposit consisting of lenticular beds of lithic ash with planar stratification lies between two pyroclastic-flow deposits at gravel pit in the Kalama River valley. (See fig. 38.) Rock fragments in the deposit beneath the stratified beds are chiefly nonvesicular dacite; those above are pumice.

matrix of each deposit seems to grade into the other. It is not known whether the lens is analogous to the pumice-block lenses within the upper pyroclastic-flow deposit, represents a part of the upper pyroclastic-flow deposit that became segregated at the top because of a relatively lower density, or was formed by a subsequent pyroclastic flow that consisted chiefly of pumice.

The pyroclastic-flow deposits at the gravel pit contain many charcoal fragments ranging in size from tiny pieces to large logs. A log with bark still attached was exposed in cross section in the lower pyroclastic-flow deposit in the late 1950's (Mullineaux and Crandell, 1962). In 1974-76, several logs were exposed in the south wall of the pit at the nearly horizontal contact of the upper and lower deposits (fig. 41). The largest of these had a diameter of $50 \mathrm{~cm}$ and an exposed length of about $7 \mathrm{~m}$. The log was surrounded by a zone a few centimeters thick from which the ash-size component of the matrix was absent, leaving voids between larger rock fragments. In addition, "pipes" having a similar openwork texture led from the top of the log upward through the upper pyroclastic-flow deposit for a distance of $20-30 \mathrm{~cm}$ (fig. 42). Some of the rock fragments in the "pipes," as well as those surrounding the log, were coated with a soft dark sooty material which apparently is an organic substance expelled during destructive distillation of the $\log$ (Mullineaux and Crandell, 1962, p. 865). The fine material probably was carried away by steam that was released as the log was baked by the hot rock debris enclosing it. If the log had laid on the surface of the lower pyroclastic flow and had burned in open air, it would have been converted to ash instead of charcoal. The logs clearly were carbonized in their present position, and their presence along the contact between the two deposits suggests that the two flows came to rest within a very short time of each other, probably less than a minute. This conclusion is supported by the presence of the openwork "pipes" that extend from the charcoal log upward into the overlying pyroclastic-flow deposit. 


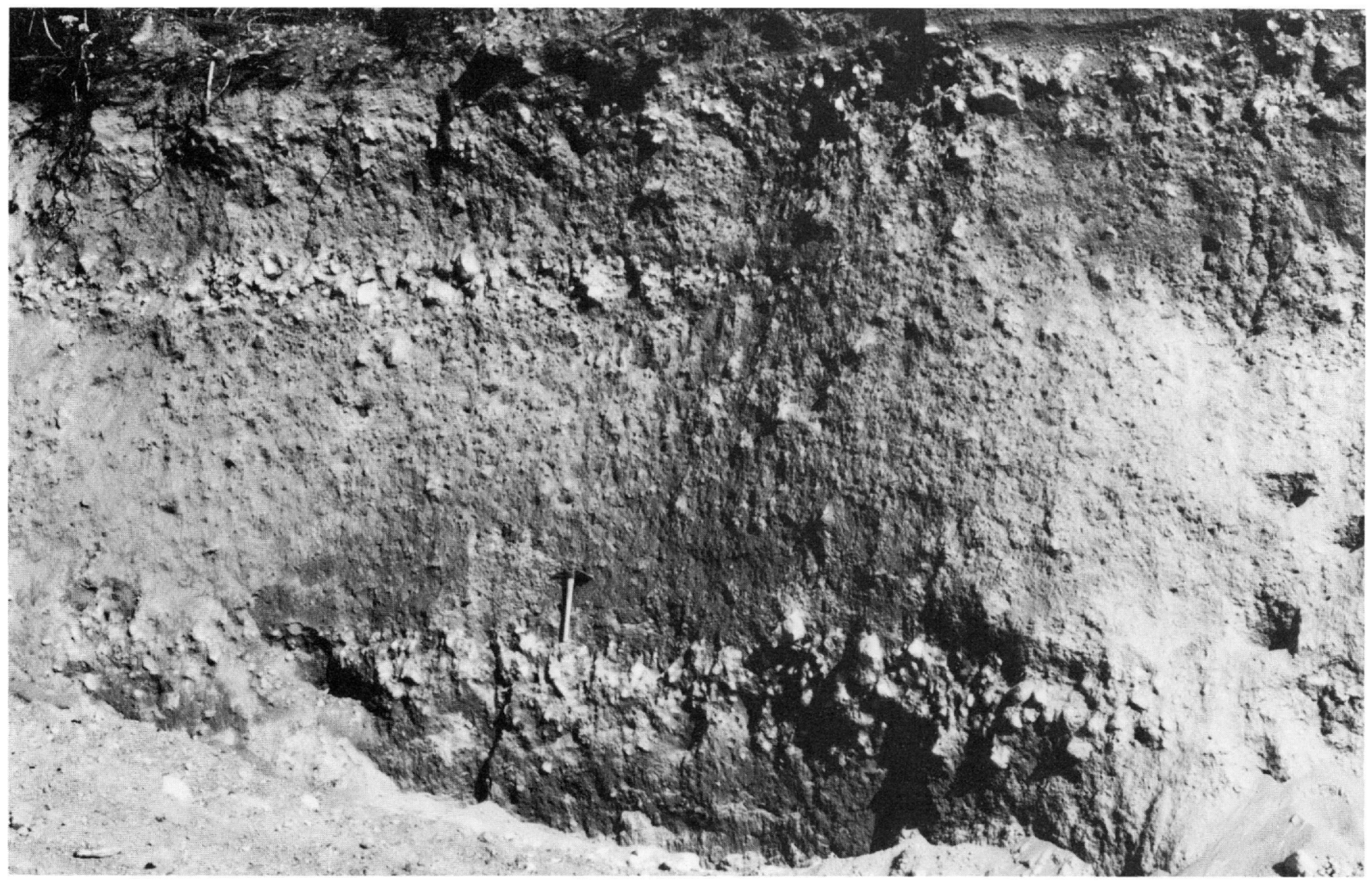

FIGURE 40.-Horizontal lenses of pumice lapilli and blocks (below and about $2 \mathrm{~m}$ above pick) within the upper pyroclastic-flow deposit exposed at a gravel pit in the Kalama River valley. (See fig. 38.)

Soon after the pyroclastic flows came to rest, the Kalama River became established in its present course on the valley fill and began to cut down through the incoherent deposits. Much of the debris eroded from the pyroclastic-flow deposits was redeposited as alluvium. Near the terminus of the pyroclastic flows, the alluvium is about $16 \mathrm{~m}$ thick; at a gravel pit $1.5 \mathrm{~km}$ farther downvalley (locality 62 ) it is 6-7 m thick. Although some thin lahars are interbedded with the alluvium near the terminus of the pyroclastic-flow deposits, only fluvial deposits are present at the gravel pit. The deposits exposed in the walls of the gravel pit are mostly sand and pebble to cobble gravel that contains a few boulders as large as $2 \times 2 \times 2.5 \mathrm{~m}$. Although most of the rock fragments are nonvesicular gray dacite, pebbles and cobbles of white pumice are common. Bedding is chiefly horizontal and planar, and individual beds are a few centimeters to $50 \mathrm{~cm}$ thick. Layers of granules and pebbles with openwork texture are abundant. A large log that protruded from the wall of the pit in 1977 (fig. 43) was carbonized only on the outside; it was charred before it was incorporated in the fluvial gravel, but where and how the charring occurred is not known.

Fluvial deposits about $4 \mathrm{~m}$ thick with generally similar characteristics are exposed in the walls of another gravel pit about $1.5 \mathrm{~km}$ farther west.

The bulk of the fluvial deposits probably originated when two narrow valleys were cut into the pyroclasticflow deposits, one of which is now occupied by the Kalama River. Both valleys contain stream-cut terraces and probably were excavated soon after the pyroclasticflow deposits were formed. Just downvalley from the terminus of the pyroclastic-flow deposits, the Kalama River left a succession of five nonpaired terraces as it cut down through the fluvial deposits; an underlying basalt lava flow ultimately inhibited further downcutting.

Lithic pyroclastic-flow deposits with an aggregate thickness of 50-60 m crop out in the north wall of a narrow trench occupied by the Kalama River (locality 61). A single reddish-gray zone $6 \mathrm{~m}$ thick occurs at the top of these deposits. Although beds of pumice or pumiceous pyroclastic-flow deposits are not exposed, one or more lithic pyroclastic flows near the bottom of the 


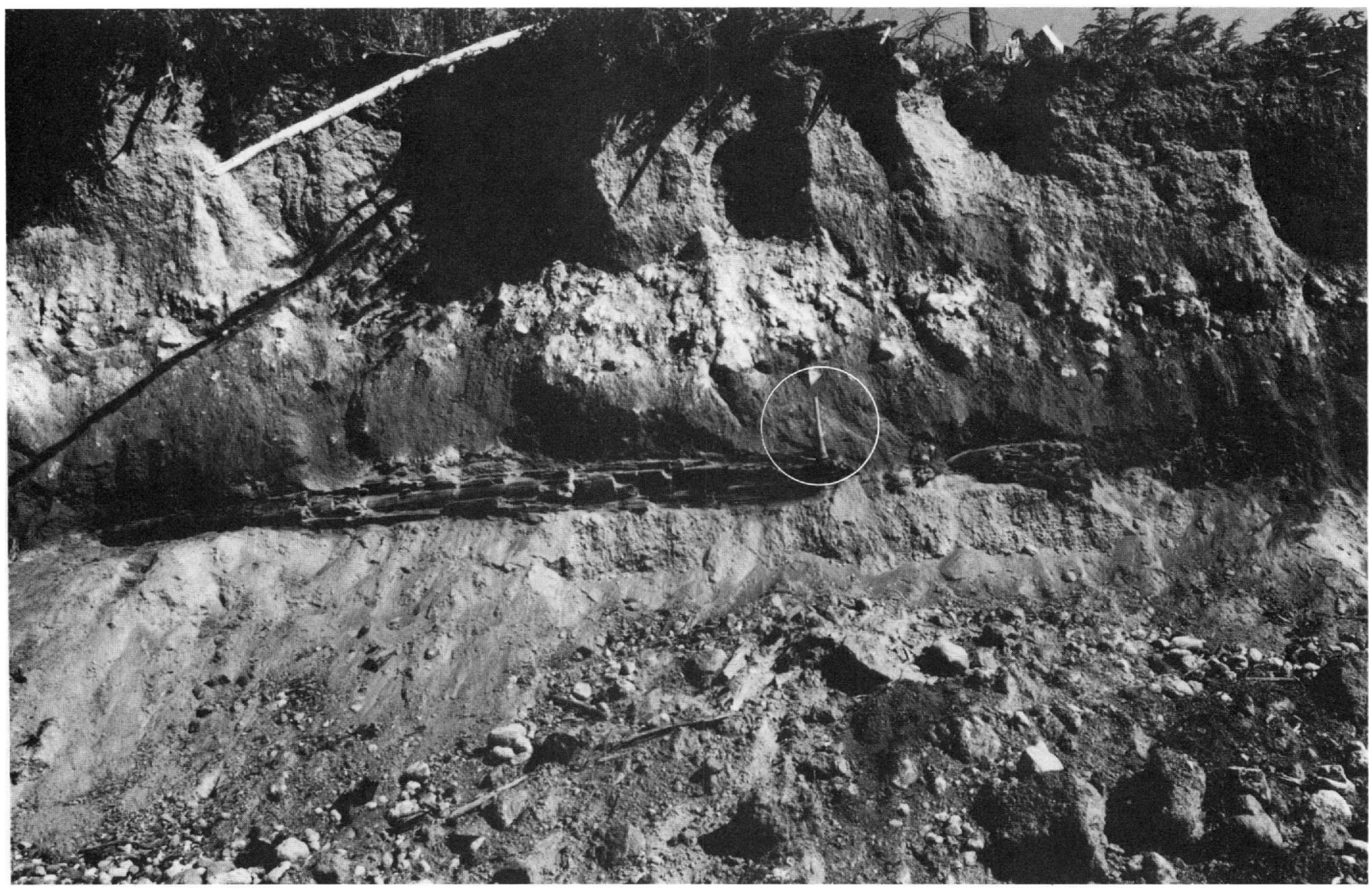

Figure 41.-Large conifer logs, now entirely converted to charcoal, lie along contact between two pyroclastic-flow deposits in south wall of borrow pit in the Kalama River valley. A lens of pumice lapilli and blocks in the upper pyroclastic-flow deposit is above pick.

outcrop do contain scattered pumice lapilli. The deposits exposed in the trench wall are probably correlative with the lower pyroclastic-flow deposit at the gravel pit (locality 63) farther downvalley. Deposits that probably correlate with the upper pyroclastic-flow deposit at the gravel pit occur at the top of the valley fill north of the trench followed by the Kalama River. The oldest tree that was found in 1974 growing on the surface of this fill had 344 annual growth rings at a height of $80 \mathrm{~cm}$ above its base; thus, vegetation became established on this surface before A.D. 1630. Upvalley from Forest Road 81 all these deposits are overlapped by younger pyroclastic-flow deposits (p. 77).

Ash-cloud deposits of massive gray lithic ash mantle the south valley wall of the Kalama River, the crest of the adjacent ridge south and west of McBride Lake, and an area east of the lake. Ash a few centimeters thick occurs at least as high as $180 \mathrm{~m}$ above the floor of the Kalama River valley on the ridgetop south of the lake. Similar deposits about $1 \mathrm{~m}$ thick are present along a road that extends up the valley wall about $2.5 \mathrm{~km}$ west of McBride Lake (locality 57). These deposits are mostly of fine to medium sand size at a height of about $60 \mathrm{~m}$ above the adjacent valley floor, but they contain scattered angular and subangular rock fragments as large as $6 \times 9 \times 10 \mathrm{~cm}$. At a height of about $150 \mathrm{~m}$, they are $15 \mathrm{~cm}$ thick and chiefly of fine sand size.

The distribution of the ash along the valley wall, and its thinning and decreasing grain size upslope, suggest that the deposits were formed by clouds of ash that accompanied pyroclastic flows moving down the Kalama River valley. These deposits contain hypersthene and hornblende but lack augite; the ash-cloud deposits therefore seem to be genetically related to the pyroclastic flows that extended as far downvalley as the gravel pit at locality 63 , rather than to a younger pyroclastic flow deposit of hypersthene-augite andesite immediately west of McBride Lake (p. 78).

Pyroclastic-flow deposits of early Kalama age also crop out in a roadcut upslope from McBride Lake (locality 55), in the wall of a pit on the southeast spur of Goat Mountain (locality 60), and in cuts along a road southwest of Blue Lake. The deposit near McBride Lake is 1-2 $\mathrm{m}$ thick and consists of fragments of nonvesicular 


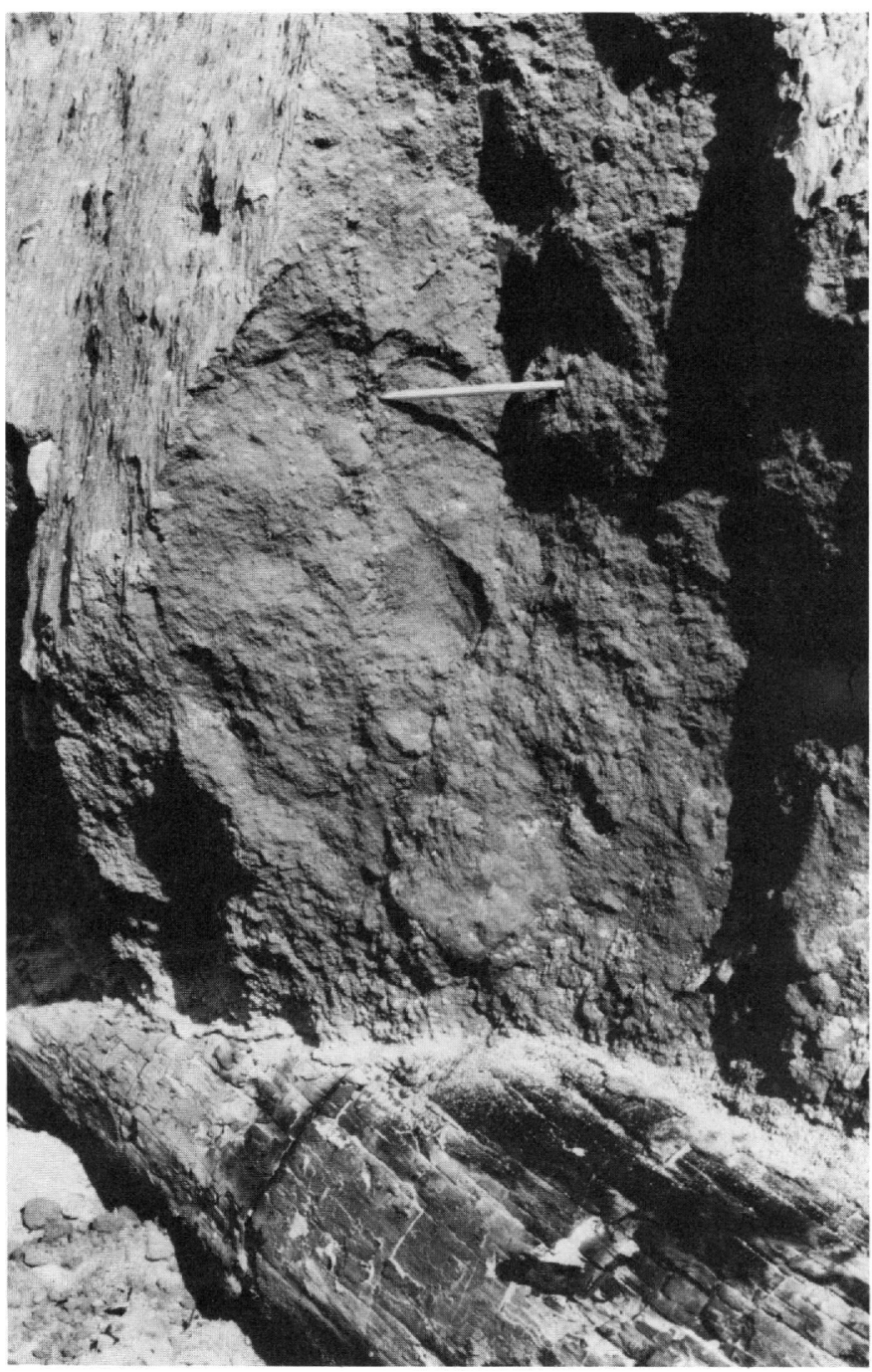

FIguRe 42.-Vertical "pipe" (at pencil point) from which fine-grained component of matrix of pyroclastic flow has been removed. "Pipe" extends upward from charcoal log that lies at contact between two pyroclastic-flow deposits. (See fig. 41.) Log also is surrounded by a zone a few centimeters thick from which fine material has been removed.

hypersthene-hornblende dacite in a lithic ash matrix. It overlies brownish-gray fine ash that contains scattered lapilli of white hypersthene-hornblende pumice of tephra set $W$. This is the only locality at which the stratigraphic relation between set $W$ and pyroclasticflow deposits of early Kalama age was observed; it is not known which part of set $W$ is represented by the lapilli near McBride Lake.

The pyroclastic-flow deposit that crops out in a pit on the southeast spur of Goat Mountain (locality 60) consists of nonvesicular fragments of gray and reddishgray hypersthene-hornblende dacite, some of them prismatically jointed, in a matrix of loose gray ash. The largest rock fragments are about $60 \mathrm{~cm}$ in maximum dimension. TRM determinations of some clasts in the deposit indicate an emplacement temperature of more than $550^{\circ} \mathrm{C}$ (R. P. Hoblitt, oral commun., 1978).

The deposit veneers the east-facing slope of the spur and probably is at least $10 \mathrm{~m}$ thick. It rests on gray lithic ash as much as $60 \mathrm{~cm}$ thick, probably an ash-cloud deposit. The ash overlies oxidized tephra of set $\mathrm{J}$, colluvium, till, and glacially striated bedrock. Logs as much as $30 \mathrm{~cm}$ in diameter are abundant in the deposit; some are entirely charcoal, others are only partly charred. The long axes of six of these logs, each longer than $2 \mathrm{~m}$, are nearly horizontal and point directly away from the volcano. The pyroclastic-flow deposit extends upslope to a height of about $70 \mathrm{~m}$ above the adjacent surface to the east, and ash-cloud deposits extend even farther upslope. The vertical height attained by the pyroclastic flow suggests a velocity of at least $37 \mathrm{~m} / \mathrm{s}$ (about $133 \mathrm{~km} / \mathrm{h}$ ) when it encountered the base of the spur.

A similar pyroclastic flow of early Kalama age moved upslope on a spur west of Blue Lake through a vertical distance of at least $100 \mathrm{~m}$, crossed the crest of the spur, then continued downslope southwestward toward Goat Marsh Lake. The resulting deposits are as much as $2 \mathrm{~m}$ thick and contain nonvesicular dacite fragments as large as $15 \times 20 \times 25 \mathrm{~cm}$ in roadcuts northeast of Goat Marsh Lake. The minimum velocity of the pyroclastic flow, suggested by the height it reached in crossing the spur, is about $44 \mathrm{~m} / \mathrm{s}(160 \mathrm{~km} / \mathrm{h})$. Ash-cloud deposits that may have been associated with this pyroclastic flow veneer the south-facing ridge northeast of Goat Mountain. These deposits are as thick as $50 \mathrm{~cm}$ at a roadcut near the center of section 14 north of Goat Mountain.

The calendar age of the pyroclastic-flow deposits of early Kalama age in the Kalama River valley is not clear, because of large differences in radiocarbon ages obtained from them. But all these deposits probably were formed after A.D. 1480, the time that tephra of layer Wn was erupted. A sample of charcoal from a log in the deposit at locality 60 , on the southeast spur of Goat Mountain, yielded a radiocarbon age of $510 \pm 50$ years (W-2989). The tree-ring calibration curve of Stuiver and Pearson (1986) indicates that this radiocarbon age corresponds to a calendar age of about A.D. 1415. A date of $610 \pm 50$ years (W-2403) was reported by Hyde (1970) from charcoal taken from the lower pyroclastic-flow deposit at the gravel pit (locality 63). Subsequently, a date of $290 \pm 70$ years (W-3995) was obtained on a sample collected from the outermost part of a charcoal $\log$ in the upper pyroclastic-flow deposit at the same locality. Correction of these two dates with the tree-ring calibration curve of Stuiver and Pearson 


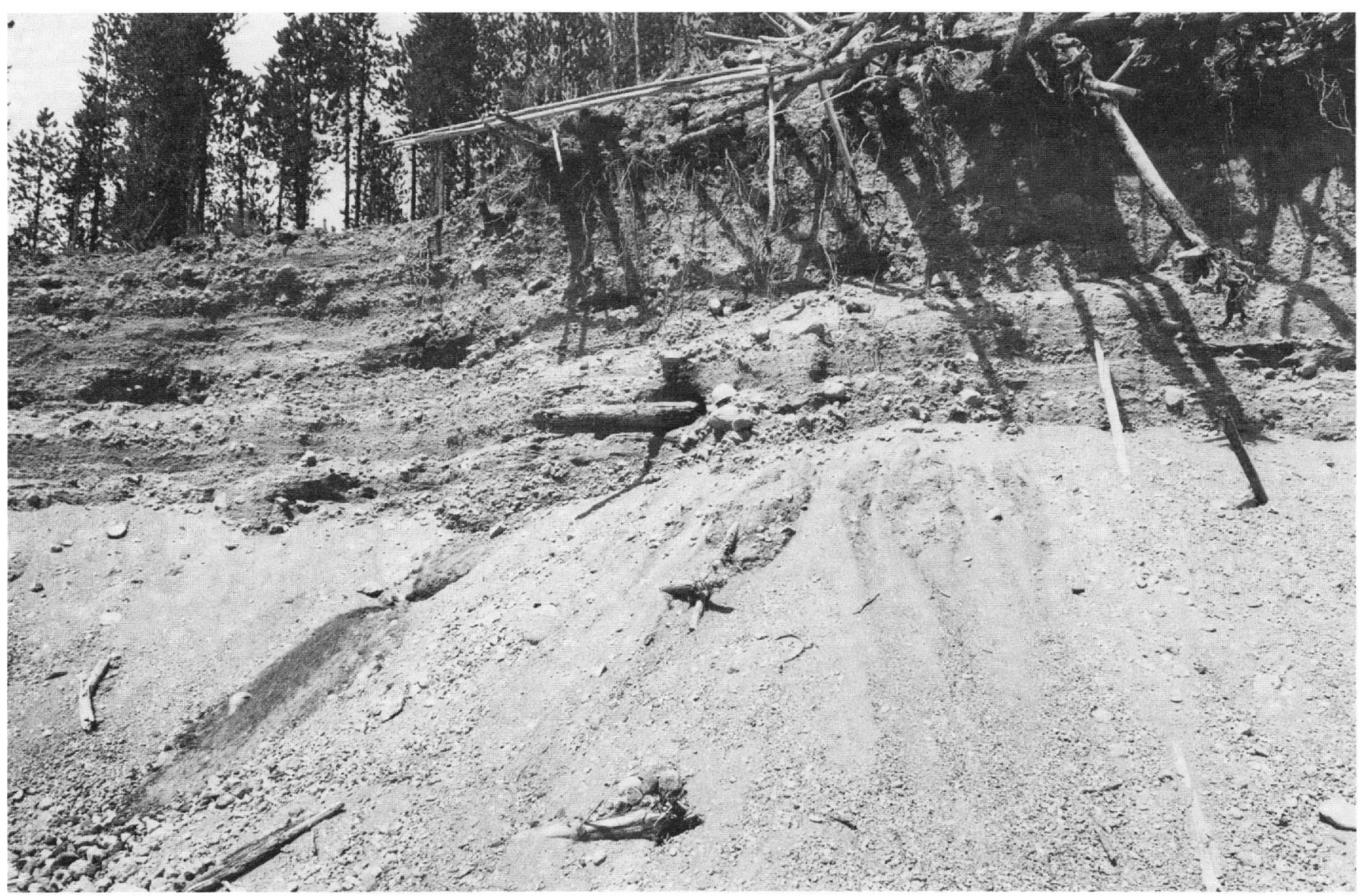

Figure 43.-Fluvial deposits of Kalama age that were derived from pyroclastic flows in the Kalama River valley (locality 62). Log protruding from wall of gravel pit is charred only on the outside; it is about $20 \mathrm{~cm}$ in diameter.

(1986) results in calendar ages, respectively, of A.D. 1310,1350 , or 1380 , and A.D. 1635 (table 10).

The origin of the lithic pyroclastic-flow deposits of early Kalama age is not clear; however, the apparent restriction of the deposits to the southwest side of Mount St. Helens is best explained by one or more collapses of a dacite dome being extruded on the flank or at the summit of the volcano. No remnant of a possible source dome has been recognized, but one may be buried beneath younger deposits.

It is possible that the inferred episode of dome extrusion occurred between eruptions of tephra layers Wn and We, which Yamaguchi (1985) has dated at A.D. 1480 and 1482 , respectively. If so, the eruption of 1482 could have begun with the explosive disruption of the dacite dome, which produced lithic pyroclastic flows represented by the deposit at the site of the gravel pit in the Kalama River valley (locality 63). This flow could have picked up pumice of previously erupted layer Wn as it moved from the dome down the flank of the volcano. Dome disruption could have been immediately followed by venting of pumiceous dacite, which produced one or more pumiceous pyroclastic flows down the Kalama River valley and which were emplaced immediately after the lithic pyroclastic flow came to rest.

\section{DEPOSITS OF MIDDLE KALAMA AGE}

The initial event of middle Kalama time was the eruption of tephra set X, which fell on all sides of the volcano (Hoblitt and others, 1980, p. 558). The tephra is chiefly ash of andesitic composition and includes at least 10 separate beds. Following the deposition of the ash, andesitic pyroclastic flows, lava flows, and lahars moved down several flanks of Mount St. Helens.

Lava flows. - Andesite lava flows were extruded after the eruption of tephra set X (fig. 37), and their distribution on most sides of the volcano suggests that they were erupted at a summit crater. The greatest volume of lava is on the south-southeast sector of the cone west of Pine Creek, where a complex of overlapping flows 


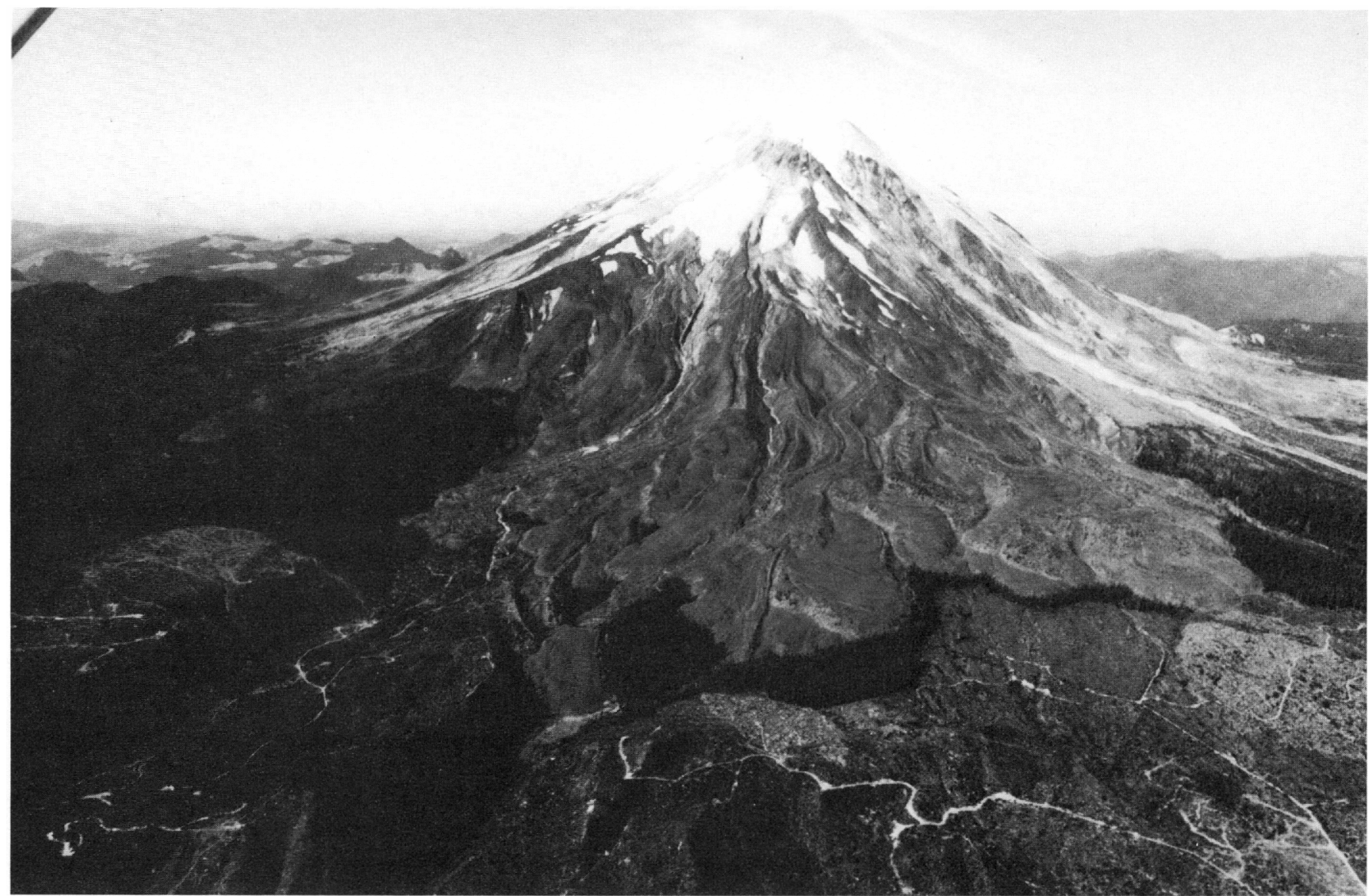

Figure 44.-Aerial view of complex of andesite lava flows of Kalama age on the southeast side of Mount St. Helens. Photograph taken in 1979 by R. P. Hoblitt, U.S. Geological Survey.

extends from an altitude of about $2,400 \mathrm{~m}$ down to about $920 \mathrm{~m}$ (fig. 44). The longest flow terminates near June Lake and is about $6 \mathrm{~km}$ long, measured from the pre-1980 summit of the volcano. A similar post- $X$ flow (Hoblitt and others, 1980, p. 558) on the west side of the volcano, terminating east-southeast of Blue Lake, is only slightly shorter. Most of the flows have high steep fronts and sides, and their tops consist of angular blocks a meter or two in diameter. Prominent levees are conspicuous features of the lava-flow complex west of Pine Creek (fig. 44). The andesite of the flows typically contains hypersthene and augite; hornblende or olivine is present in some flows. Rhizocarpon sp. lichens measured on surfaces of blocks of several flows near June Lake have maximum diameters of as much as $165 \mathrm{~mm}$.

Post-X andesite-bearing lahars that may be genetically related to some of these middle Kalama lava flows crop out along Forest Road 83 on the south side of the volcano (p. 69).

Pyroclastic-flow deposits.-At least two pyroclastic- flow deposits of middle Kalama age underlie an area about $1.5 \mathrm{~km}$ wide and 5-6 km long southwest of the volcano; the deposits split into two lobes west of McBride Lake (fig. 45). Forest Road 81 crosses the easternmost lobe and Road 8123 follows the longitudinal slope of the western lobe north and northwest of McBride Lake.

The older of the two deposits is exposed in a cut just east of the junction of Forest Roads 81 and 8123 (locality 56). It consists of subangular to subrounded boulders and blocks as large as $1 \mathrm{~m}$ in diameter in a fine to coarse lithic ash matrix. The clasts are of a gray andesite that contains hypersthene and hornblende, accompanied by augite in some fragments. The deposit has a reddishgray zone $3.5 \mathrm{~m}$ thick at its top. The surface of the deposit east of the roadcut is incised by a lahar-floored channel, beyond which the surface of the pyroclasticflow deposit is littered with blocks as much as $3 \mathrm{~m}$ in diameter.

This pyroclastic-flow deposit is stratigraphically younger than those at the gravel pit (locality 63) 


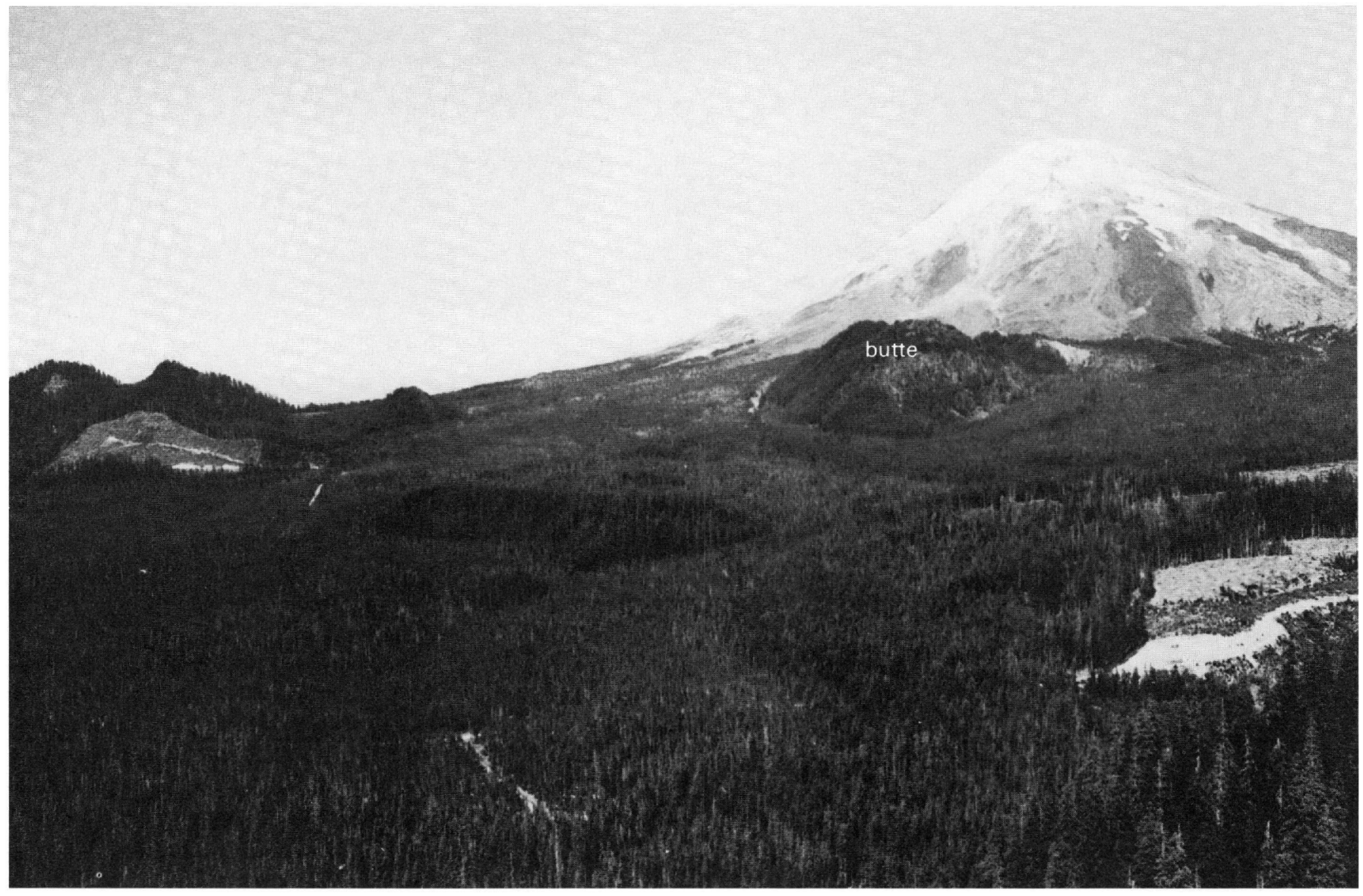

FIGURE 45.-View northward across surface of pyroclastic-flow deposits of Kalama age southwest of Mount St. Helens. McBride Lake is downslope from roadcut at right. "Butte canyon" is to the left of hill identified as "butte." Photograph taken in 1978.

farther down the Kalama River valley, but the age difference in years is not known.

Still farther east, this deposit is overlapped by a pyroclastic-flow deposit of black scoriaceous hypersthene-augite andesite. Large blocks of the andesite, many of them breadcrusted, litter the surface of the pyroclastic flow (figs. 46, 47). This deposit can be traced upslope to an altitude of about $1,500 \mathrm{~m}$ on the west flank of the volcano. It underlies most of the flattish area in the SW1/4 sec. 17 north of Butte Camp, veneers two andesite lava flows in section 18 , and extends downslope along the southern lava flow and in low areas adjacent to the flows. The deposit consists almost wholly of blocks of scoriaceous andesite (fig. 48) in outcrops along the north side of "butte canyon" (locality 59). Large blocks of the same rock form elongate west-trending ridges on the first lava flow north of "butte canyon" which seem to be levees formed along the edge of one or more pyroclastic flows.

Cuts along Forest Road 81 west of McBride Lake reveal a reddish-gray zone $1.5-1.7 \mathrm{~m}$ thick at the top of the pyroclastic-flow deposit of black andesite. Progressive thermal demagnetization of six clasts taken from a roadcut about $0.5 \mathrm{~km}$ west of McBride Lake indicated an emplacement temperature at or above $550^{\circ}-600^{\circ} \mathrm{C}$ (Hoblitt and Kellogg, 1979).

The age of the pyroclastic flow of scoriaceous black andesite is not precisely known. A tree stump on the deposit west of McBride Lake had 294 growth rings at a height of $50 \mathrm{~cm}$ above the base; the tree must have been more than 300 years old when it was cut during the 1970's. On the southwest slope of the volcano, the pyroclastic flow of black scoriaceous andesite is locally overlain by lahars of dacitic rock debris derived from the summit dome.

The scoriaceous nature of the large breadcrusted blocks in the pyroclastic-low deposit suggests that the flow did not originate in a dome, but resulted from massive eruptions of fragmental material. The deposit of a hot lahar on the north side of the volcano near Spirit Lake Lodge contained similar breadcrusted blocks of scoriaceous hypersthene-augite andesite, and a small 


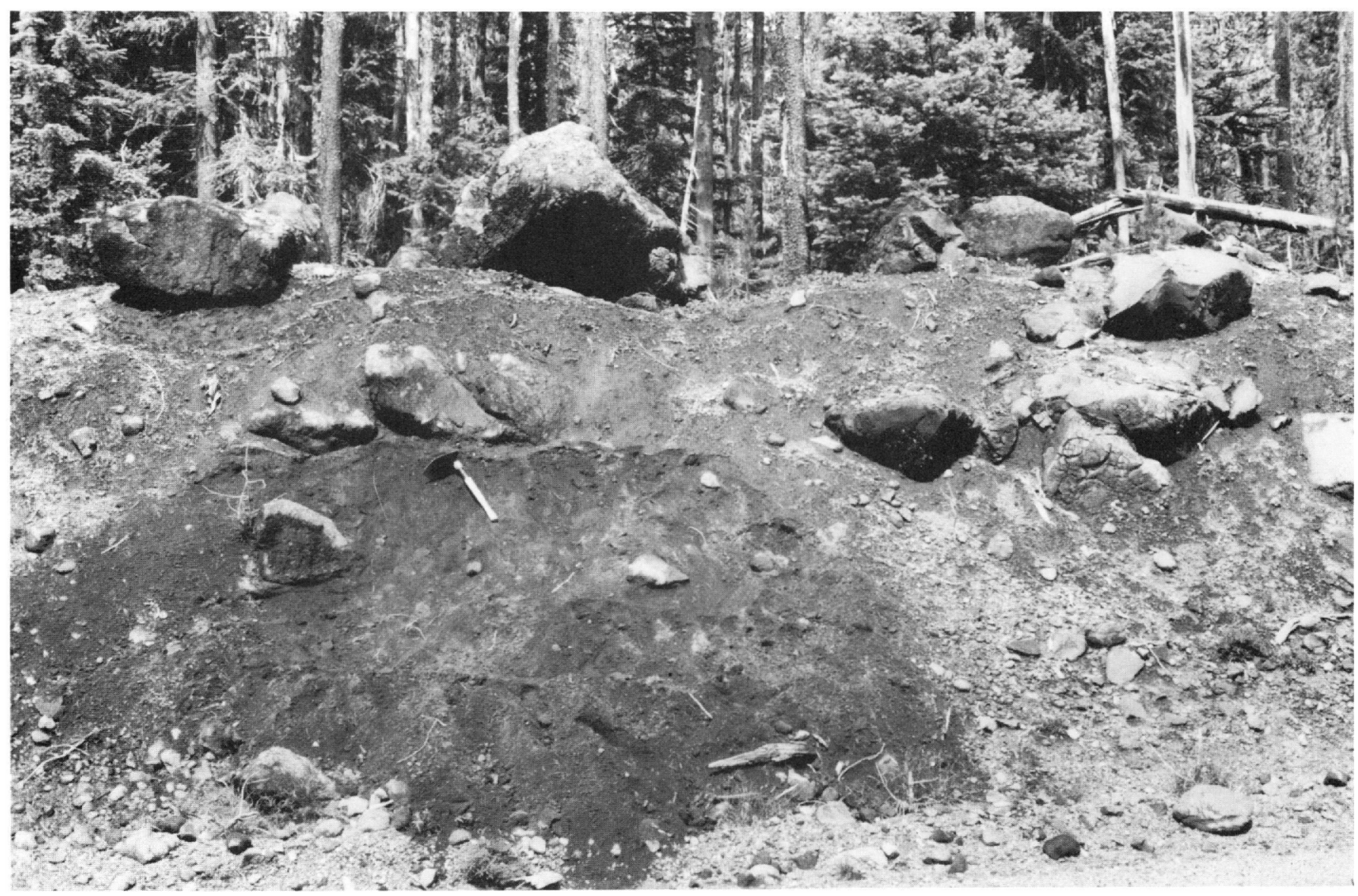

Figure 46.-Pyroclastic-flow deposit consisting of scoriaceous blocks of black andesite in a lithic ash matrix, exposed at a roadcut 0.5 km west of McBride Lake.

deposit of unknown origin that contains the same rock type has been noted by R. P. Hoblitt (oral commun., 1981 ) on the summit of east dome. The limited distribution of these deposits suggests that they were not produced by a vertical eruption of material that fell on all sides of the volcano. Instead, the deposits probably were formed by fragmental material that poured out of the summit crater across low places in the crater rim.

Deposit of hot lahar(?) near Spirit Lake Lodge.-An unsorted and unstratified deposit probably formed by a lahar carrying hot rock debris cropped out, before 1980 , in the south bank of the North Fork Toutle River at locality 1 (measured section 14). The rock fragments were breadcrusted blocks as large as $2 \mathrm{~m}$ in diameter of scoriaceous black hypersthene-augite andesite that were lithologically similar to those in a pyroclastic-flow deposit west of McBride Lake. Smaller rock fragments were mostly dense gray andesite. The deposit contained wood fragments of many sizes, most of them converted to charcoal. Some wood fragments were only partly carbonized, however, and others that were found in an earlier study of the deposit were uncharred (Mullineaux and Crandell, 1962). Some fragments of charcoal noted in the earlier study were branched twigs less than a centimeter in diameter, and others were long slender branches with bark still attached.

From the earlier study, Mullineaux and Crandell (1962) inferred that the matrix of the hot lahar(?) was so cool by the time it reached the Spirit Lake Lodge locality that it could not char wood, and that the large clasts evidently did not retain enough heat and were not numerous enough to heat all of the enclosing matrix to their temperature.

Partial thermal demagnetization of blocks in the deposit indicate emplacement temperatures ranging from less than $300^{\circ} \mathrm{C}$ to probably more than $450^{\circ} \mathrm{C}$ (R. P. Hoblitt, oral commun., 1979).

A few vertical openwork "pipes" were noted at the top of the deposit. These were as much as $5 \mathrm{~cm}$ wide and a meter in length and resembled those at the top of the deposit of a hot lahar of Smith Creek age.

The calendar age of the deposit near Spirit Lake Lodge is not known. Mullineaux and Crandell (1962) reported that tree-ring counts of stumps on the deposit 


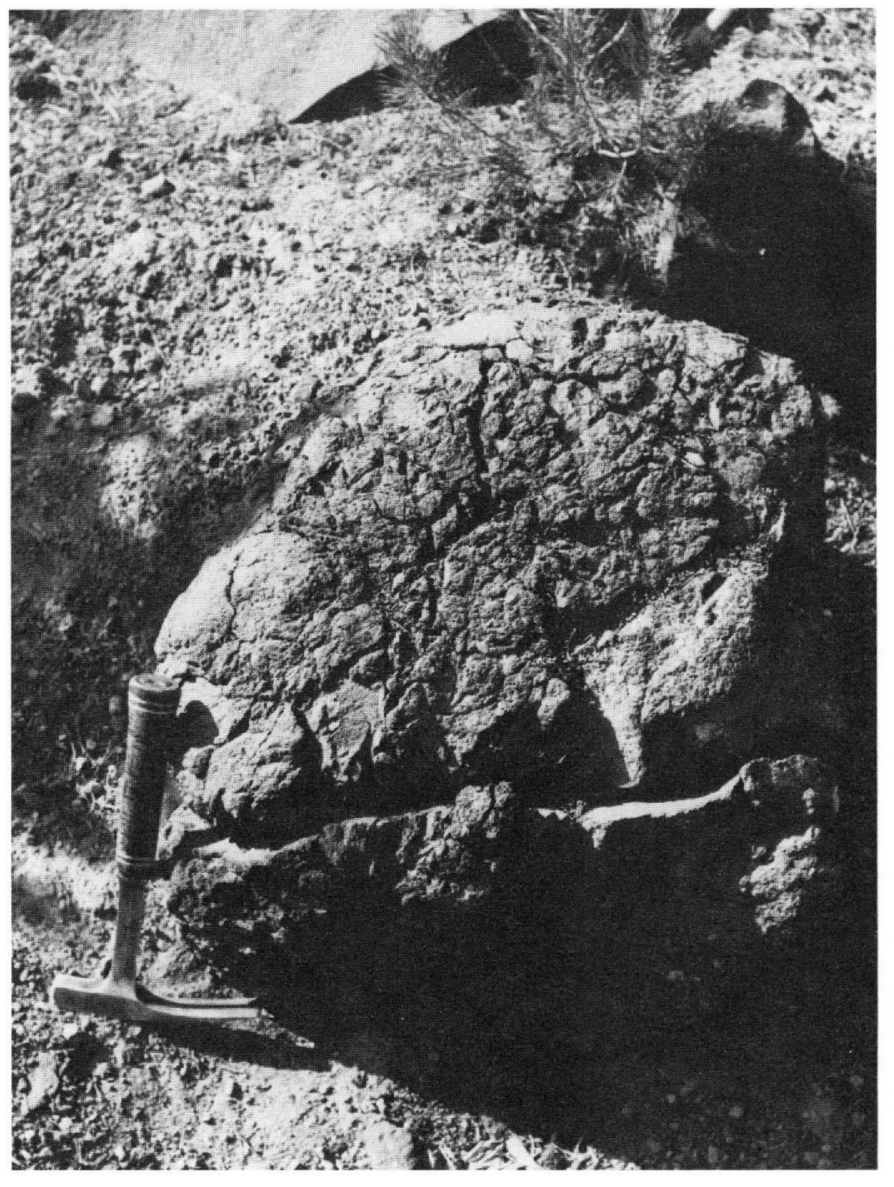

Flgure 47.-Breadcrusted block of scoriaceous black andesite in pyroclastic-flow deposit of Kalama age $0.5 \mathrm{~km}$ west of McBride Lake.

suggested an age of about 330 years (about A.D. 1630), but this is only an upper bracketing date. The outer part of a charcoal log enclosed in the deposit had a radiocarbon age of $275 \pm 60$ years (W-3991). The corrected date determined from the calibration curve of Stuiver and Pearson (1986) is about A.D. 1640. The lahar(?) may have originated about the same time that the pyroclastic flow of black scoriaceous andesite moved down the southwest flank of the volcano to the vicinity of McBride Lake and may have been caused by a similar pyroclastic flow on the north flank of the volcano.

\section{DEPOSITS OF LATE KALAMA AGE}

During a late part of the Kalama eruptive period, perhaps about 400 years ago, a dacite dome was extruded at the summit of Mount St. Helens (fig. 49). Avalanches of rock debris on the flanks of the volcano accompanied the growth of the dome and were followed by a few pyroclastic flows of pumiceous material. All of this rock debris contains hypersthene accompanied by small amounts of hornblende and augite. The rock that formed the dome is a distinctive light-gray and reddish-gray fine-grained dacite. Much of the debris from the dome moved downslope as hot avalanches, but beyond the base of the volcano, the debris was carried chiefly by lahars.

The most extensive deposits of debris derived from the summit dome underlie a broad area adjacent to the upper part of Pine Creek and Muddy River. These deposits head in a fan whose apex is at an altitude of about $1,500 \mathrm{~m}$ on the east-southeast side of the volcano (fig. 50). In section 13, downstream from the terminus of Shoestring Glacier, the fan surface was littered with prismatically jointed blocks of dacite (fig. 51) before the 1980 eruptions, and the fan deposits appeared to have been formed by a succession of pyroclastic flows and hot lahars. Similar blocks of dacite from the summit dome were present adjacent to Pine Creek as far downvalley as the center of section 30 . Thermoremanent magnetization studies of three of these blocks indicated an emplacement temperature of more than $500^{\circ} \mathrm{C}$, whereas two rock fragments that were not prismatically jointed were emplaced at temperatures of about $200^{\circ} \mathrm{C}$ (Hoblitt, 1978, p. 98). This range of emplacement temperatures suggests that the deposit was formed by a lahar that was carrying hot rock debris (Hoblitt, 1978, p. 105-107). The oldest tree found on this deposit in 1970 , represented by a stump adjacent to Forest Road 83 , had 220 growth rings at a height of $45 \mathrm{~cm}$ above its base.

Still farther down the Pine Creek valley, a lahar that consists of rock debris from the summit dome veneers a terrace that is about $13 \mathrm{~m}$ above the level of the creek (locality 35). The lahar evidently was more than $13 \mathrm{~m}$ deep when it moved down this part of the valley, but the deposit it left on the terrace is only about half a meter thick.

A succession of similar lahars flowed down the Muddy River valley and built a thick fan of rock debris (fig. 52) at the confluence of the river and Smith Creek. Before the 1980 eruptions, the margins of this fan dammed tributary valleys to form the basins of two small lakes. The oldest tree found on this deposit in 1970 had 210 annual growth rings at a height of $90 \mathrm{~cm}$ above the ground surface.

Lahars of rock debris from the summit dome partly buried a mature forest near the south base of the volcano. Before 1980, the upright stumps of large trees were visible in the walls of a borrow pit (locality 51) (fig. 53) about $3 \mathrm{~km}$ east of McBride Lake. Trees growing on these deposits were as old as 250 years when they were cut, probably during the 1960's (Hyde, 1973, p. 72-73). 


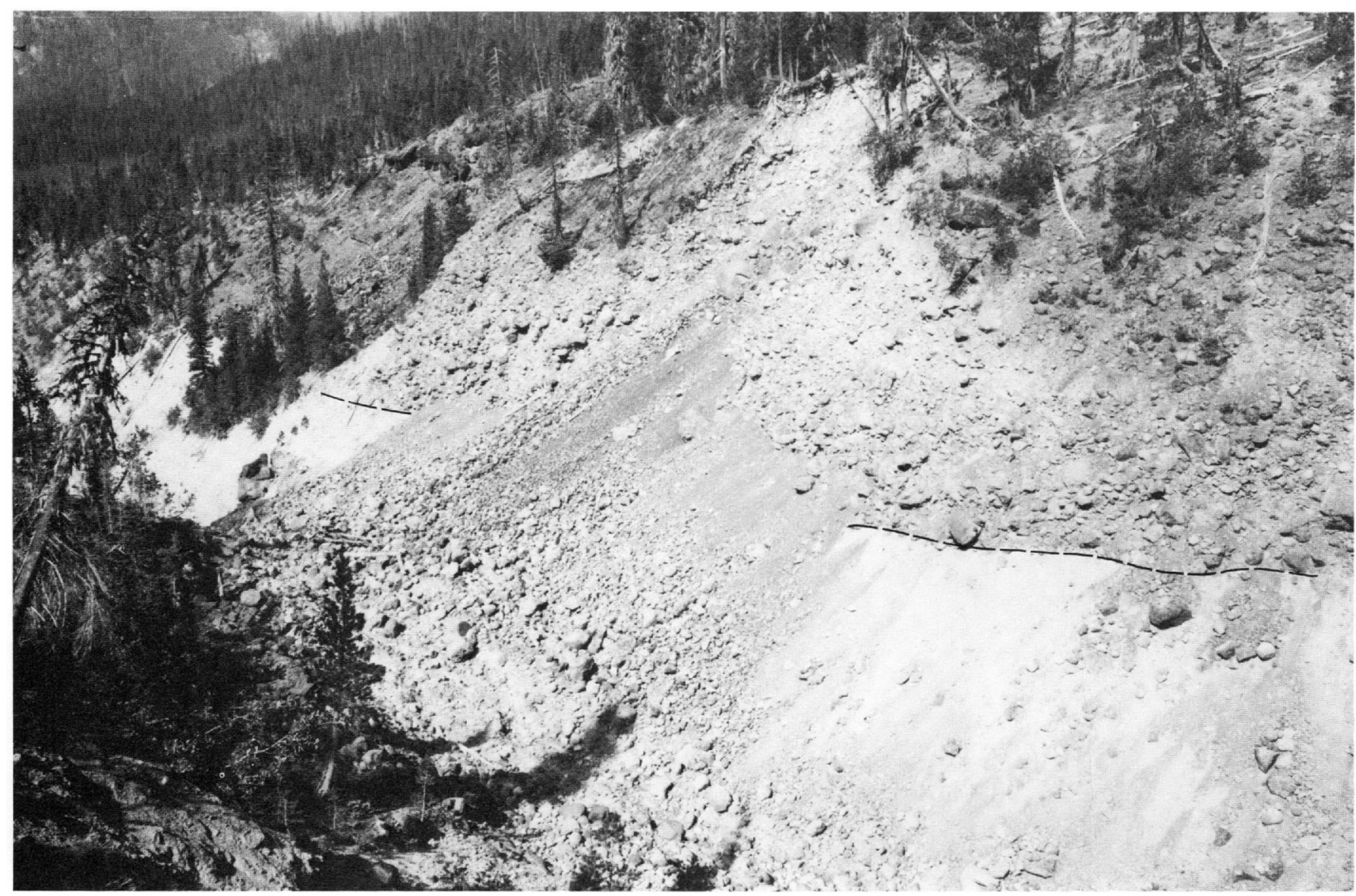

FiguRE 48.-View down "butte canyon" on southwest flank of Mount St. Helens showing pyroclastic-flow deposit of Kalama age consisting of breadcrusted blocks of scoriaceous black andesite (above dashed line). Largest blocks at right side of photograph are about $1 \mathrm{~m}$ in diameter.

Lahars of summit-dome dacite are present along low areas between andesite lava flows of middle Kalama age on the west side of the volcano. Downslope from the ends of the flows, the deposits merge and form a broad fan that dams the valley of Coldspring Creek to form the basins of Blue Lake and Goat Marsh Lake (fig. 48). In section 7 , on the low west side of the volcano, summit-dome rock debris, some of it prismatically jointed, is mixed with blocks of mineralogically similar light-gray pumice. This debris veneers the lava flows, forms thicker deposits between the flows, and has a vertical range of several tens of meters. The lithology and distribution of the deposits suggest that they were formed by one or more pyroclastic flows.

Rock debris from the summit dome forms a large dissected fan on the northwest flank of the volcano between Studebaker Creek and Castle Creek (fig. 54). Before 1980, large blocks of prismatically jointed dacite were scattered on the surface of the fan, and the fan deposits extended down the Studebaker and Castle Creek valleys to the North Fork Toutle River where they capped terraces as much as $12 \mathrm{~m}$ above river level. The fan deposits once filled the head of the canyon of the South Fork Toutle River, as well as the canyon at the head of Studebaker Creek, and were subsequently removed by erosion. Before the 1980 eruptions, lahars were observed as far down the South Fork valley as $11 \mathrm{~km}$ from the base of the volcano. Near the mouth of Coldspring Creek, about $6 \mathrm{~km}$ from the base of the volcano, a fine-grained lahar of summit-dome debris caps a terrace formed of older lahars on the south side and about $17 \mathrm{~m}$ above the South Fork (locality 72). A $7.5-\mathrm{m}$ terrace on the north side of the river in the same area is underlain by bouldery fluvial gravel interbedded with lahars. The deposit that caps the terrace on the south side of the river probably does not represent a higher and thicker continuous valley fill, but evidently is a veneer left on pre-existing surfaces after a deep lahar moved on down the valley.

A pyroclastic-flow deposit in the Castle Creek valley as much as $2 \mathrm{~m}$ thick overlies lahars of dacite rock debris from the summit dome. The deposit also was 


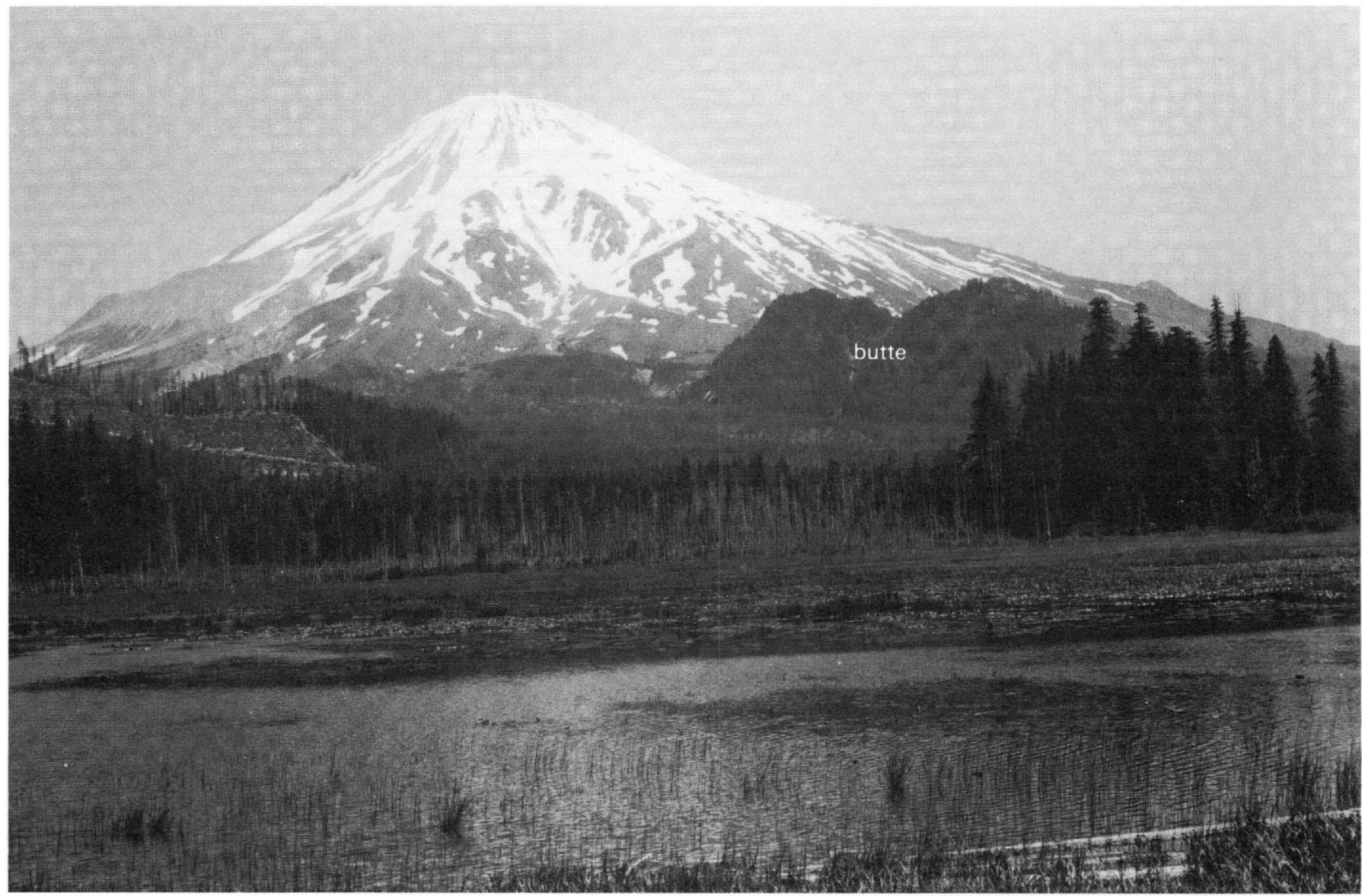

Figure 49.-View of west side of Mount St. Helens from Goat Marsh Lake. The summit of the volcano consists of a dacite dome of Kalama age. Most of the smoothly sloping surface to the left and front of "butte" is underlain by pyroclastic-flow deposits of Kalama age that are older than the summit dome. Photograph taken in 1978.

noted in 1977 in cuts along a logging road being constructed along the north canyon wall of the South Fork Toutle River (locality 75). The pyroclastic flow evidently moved downslope on the fan of rock debris from the summit dome and extended northwestward into the Castle Creek valley as well as into the canyon of the South Fork Toutle River.

The pyroclastic-flow deposit consists mostly of ash, but contains blocks of pumiceous silicic andesite as much as $30 \mathrm{~cm}$ in diameter, some having breadcrusted surfaces. Hypersthene, hornblende, and augite are present in the pumiceous rock. Its $\mathrm{SiO}_{2}$ content is 60.8 percent (sample 11, app. A), which is lower than that of the summit dome (64 percent; Hoblitt and others, 1980). In section 25 in the Castle Creek valley (locality 82 ), the pyroclastic-flow deposit contains branches and twigs of charcoal. A radiocarbon age determination of the charcoal resulted in a date of $350 \pm 60$ years (W-3150). This radiocarbon age corresponds with calendar dates of about A.D. 1510 and 1610 on the calibration curve of
Stuiver and Pearson (1986). The oldest tree found on the pyroclastic-flow deposit was more than 290 years old when it was cut down about 1970 .

Stratigraphic relations of the pyroclastic-flow deposit to rock debris from the summit dome indicate that these deposits are of nearly the same age. This inference is based on a lack of weathering at the top of the lahars of summit-dome debris where they are overlain by the pumiceous pyroclastic-flow deposit in the Castle Creek valley.

\section{NATURE AND AGE OF VOLCANISM}

A variety of eruptive events occurred during the Kalama eruptive period when the volcano acquired most of its pre-1980 shape. The initial explosive eruptions of dacite pumice formed tephra layer $W n$ and were followed by the extrusion of a dacite dome at or near the summit of the volcano. This activity was followed 


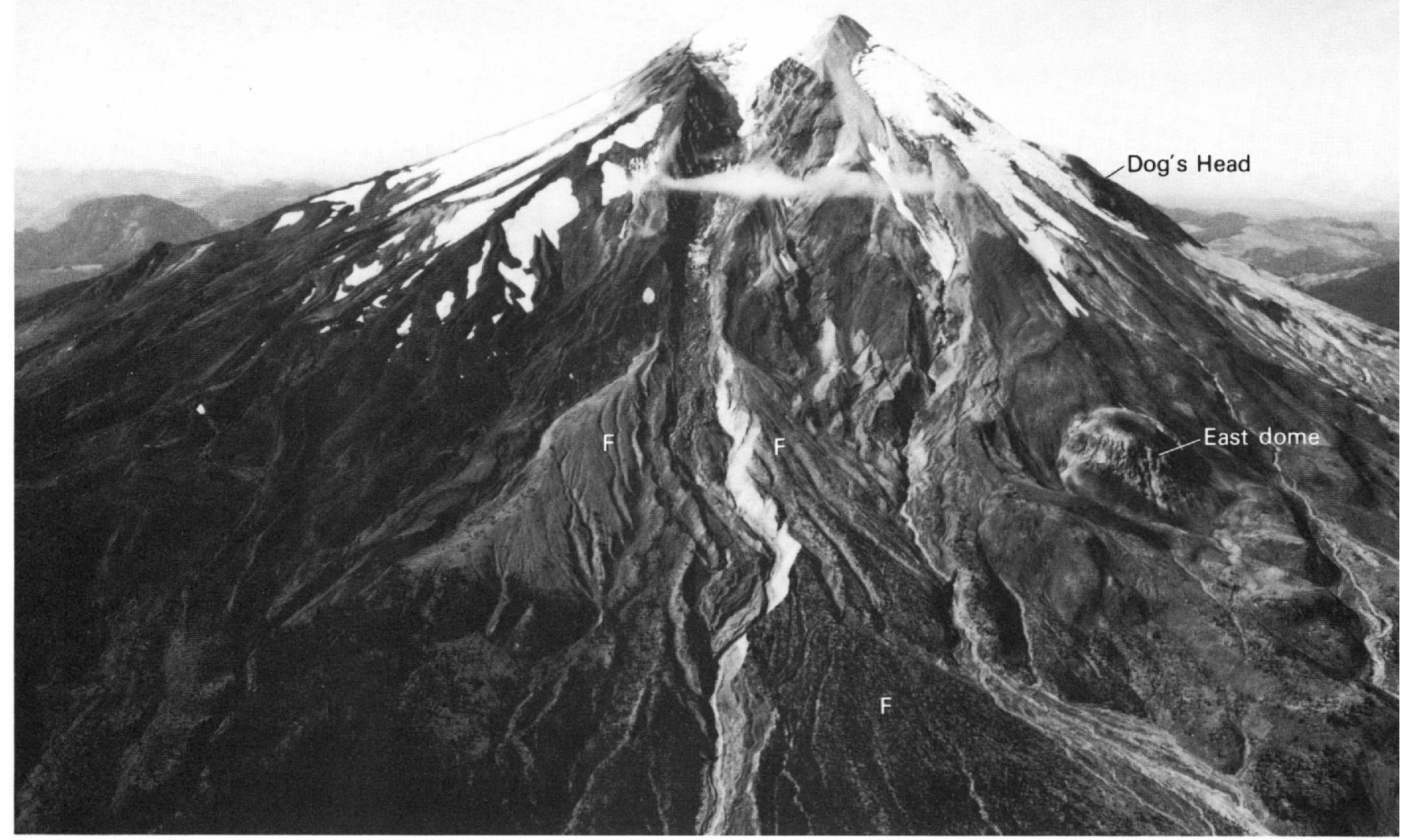

FigURE 50.-Aerial view of the southeast side of Mount St. Helens, showing fan (F) of laharic debris of Kalama age derived from the summit dome. East dome may have been formed during the Sugar Bowl eruptive period. Photograph taken in 1979 by R. P. Hoblitt, U.S. Geological Survey.

shortly by explosive eruptions which produced the multiple andesitic ash layers of tephra set $\mathrm{X}$. Later lava flows of andesite which affected nearly every side of Mount St. Helens were followed by explosive eruptions which produced pyroclastic flows on the north and southwest sides of the volcano. After these eruptions, a dacite dome was extruded at the summit of the volcano, and the eruptive period concluded with the formation of small pyroclastic flows of pumiceous highsilica andesite.

The date of A.D. 1480 (Yamaguchi, 1982, 1983) for tephra layer $\mathrm{Wn}$ is inferred to represent the beginning of the Kalama eruptive period, and the radiocarbon date of about 350 years on the youngest pyroclastic-flow deposit of Kalama age indicates a calendar age between A.D. 1510 and 1610 . These dates suggest that the eruptive period lasted about a century. I infer that the period was characterized by episodes of intense eruptive activity, separated by longer intervals of quiescence. Some events described here, such as eruptions of tephra and repeated pyroclastic flows, probably occurred during relatively short episodes of activity, measured in terms of hours, days, or months. Others, such as the extrusion of lava to form domes or lava flows, may have continued for at least several years.

\section{GLACIAL DEPOSITS OF HOLOCENE AGE}

Moraines and other glacial deposits of late Holocene age were observed adjacent to existing glaciers on Mount St. Helens during field studies in the 1970's. These deposits were not examined in detail, but a few observations are recorded here concerning moraines adjacent to Shoestring Glacier on the southeast side of the volcano.

A large steep fan of rock debris, derived chiefly from the pre-1980 summit dome of the volcano, lies adjacent to and downslope from the end of Shoestring Glacier (locality 21) (fig. 49). Although the bulk of the rock debris in the fan probably avalanched from the dome as it was being extruded, much of the debris was subsequently redistributed by Shoestring Glacier. The 


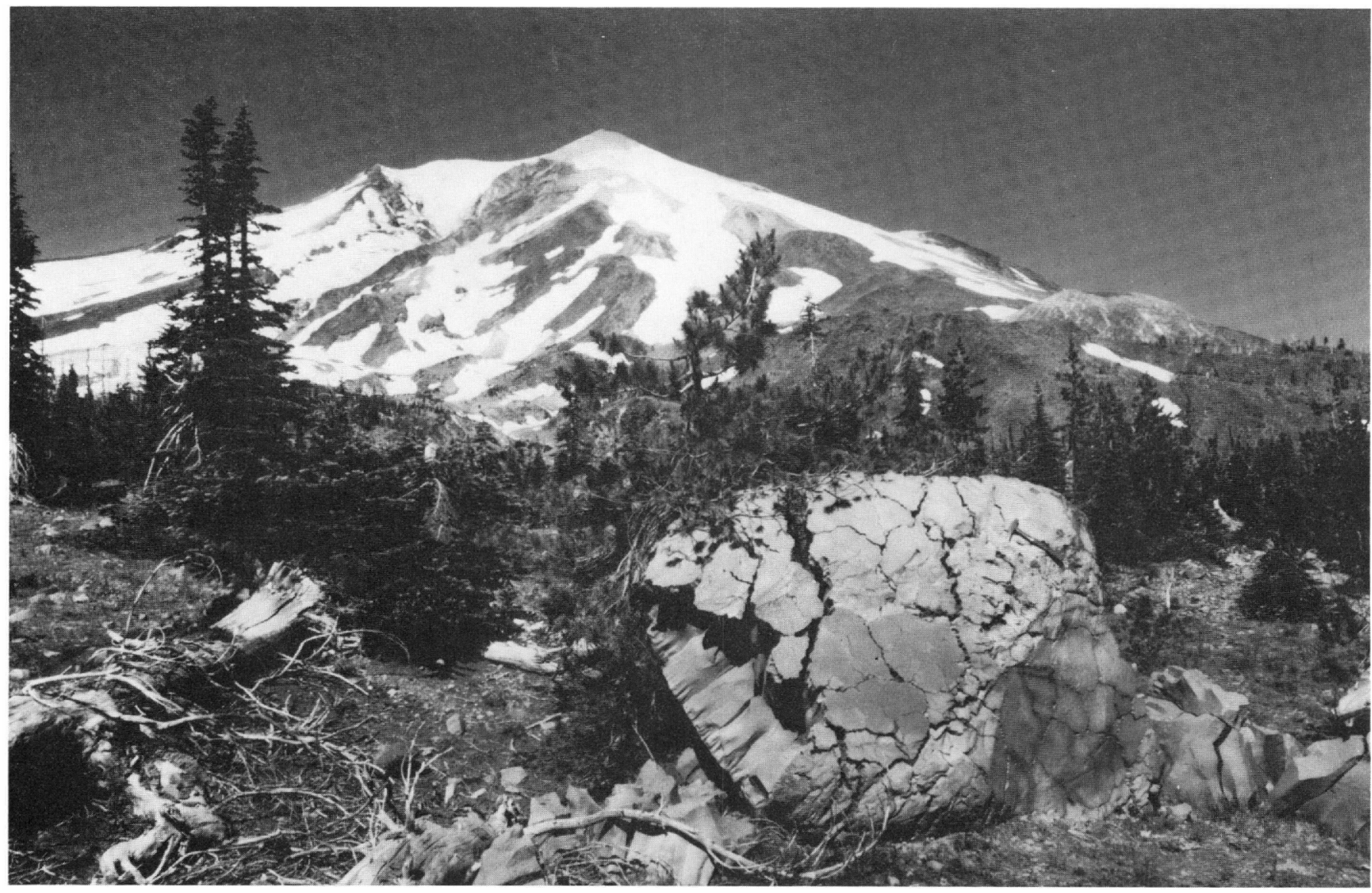

Figure 51.-Prismatically jointed block of dacite from the summit dome of Mount St. Helens. The block is about $3 \mathrm{~m}$ in diameter and lies on a fan formed by hot lahars and pyroclastic flows between Pine Creek and Muddy River at the southeast base of the volcano. Photograph taken in 1972.

resulting moraines are present on both sides of the glacier, but are better developed on the south side. These moraines have not been dated directly, but the ones on the south side are overlain by scattered lapilli of tephra layer T, hence they were formed before A.D. 1800. They may date from a period during the mid-1700's when glaciers at Mount Rainier were forming end moraines (Crandell and Miller, 1974, p. 50). The largest Rhizocarpon sp. lichen noted on the moraines in 1971 had a diameter of $50 \mathrm{~mm}$. After forming this group of end moraines, the glacier shrank and became much narrower but slightly longer. The oldest tree found on a moraine formed by the narrower and longer glacier started to grow about A.D. 1900, and the largest Rhizocarpon sp. lichen noted on the moraine had a diameter of $30 \mathrm{~mm}$.

\section{GOAT ROCKS ERUPTIVE PERIOD}

The Goat Rocks eruptive period began with an explosive eruption that produced pumice of tephra layer T in A.D. 1800 (Yamaguchi, 1983) and ended in 1857.
The tephra eruption was followed several decades later by the eruption of an andesite lava flow and extrusion of the Goat Rocks dacite dome. Many eruptions between 1835 and 1857 were witnessed by inhabitants of the surrounding region and were recorded in local newspapers. Such reports commonly included such terms as "smoke," "fire," and "flame," and on several occasions small amounts of ash were deposited many tens of kilometers from the volcano. The historic record of these eruptions is summarized by Harris (1976), and Majors (1980) noted reports of minor activity at the volcano on three occasions between 1889 and 1921.

\section{DEPOSITS}

\section{TEPHRA LAYER T}

The initial eruption of the Goat Rocks eruptive period produced dacite pumice which contains hypersthene, hornblende, and augite, and which has a $\mathrm{SiO}_{2}$ content of 64 percent (Hoblitt and others, 1980). The tephra was 


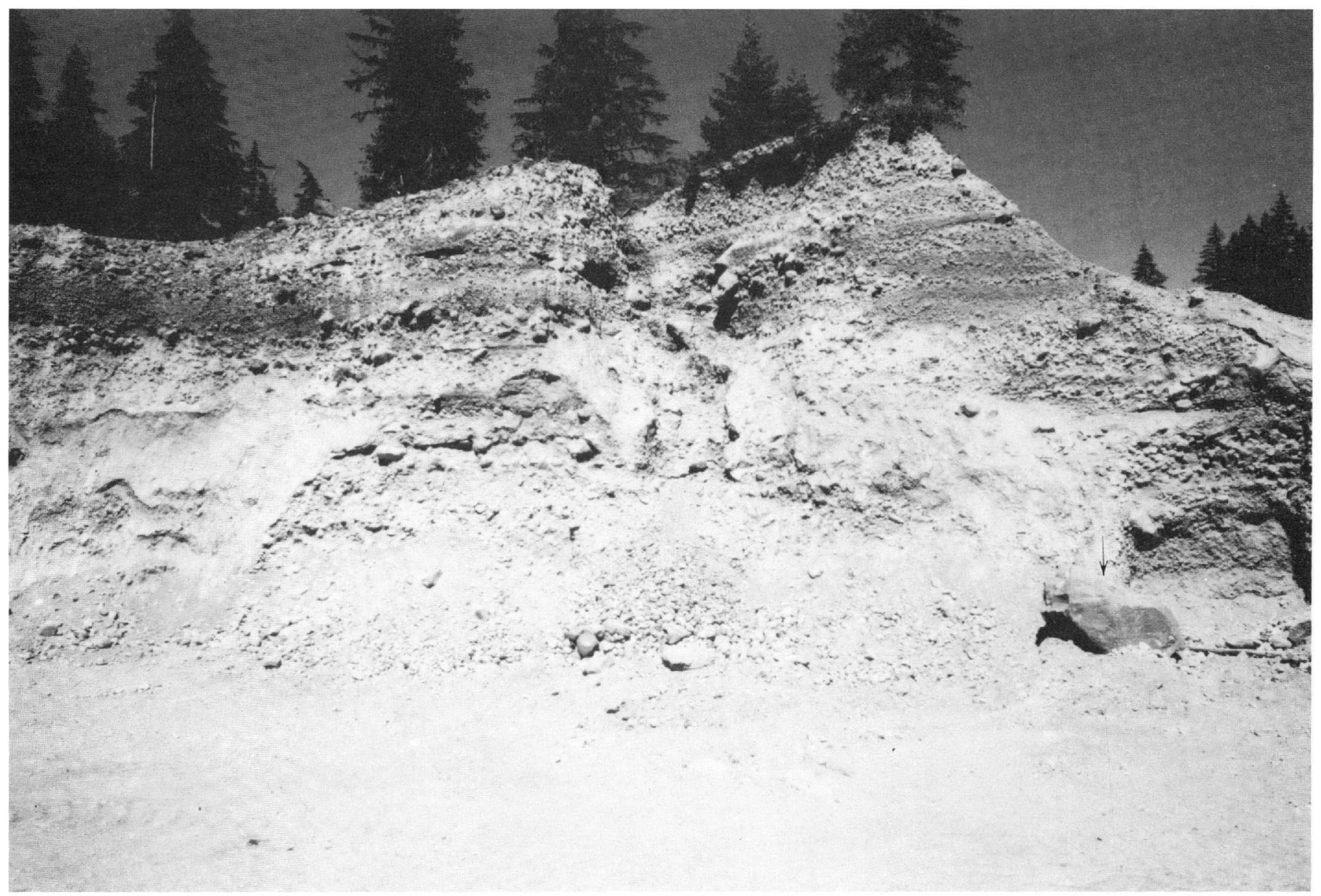

FIGURE 52.-Lahars exposed in a pit near the confluence of the Muddy River and Smith Creek. Rock debris in the deposits is mostly dacite derived from the summit dome of Mount St. Helens and carried down the Muddy River valley. The block on the pit floor at right center (arrow) is about $1.5 \mathrm{~m}$ across. Photograph taken in 1978.

carried mostly northeastward from the volcano by winds and fell at least as far away as northwestern Montana, some $575 \mathrm{~km}$ from Mount St. Helens (Okazaki and others, 1972). The estimated volume of tephra layer $\mathrm{T}$ is on the order of $0.1 \mathrm{~km}^{3}$ (Crandell and Mullineaux, 1978). No deposits of pyroclastic flows or lahars are known to have been formed at the time this tephra was erupted.

Hopson (1971) suggested that the tephra was erupted from the vent at which the Goat Rocks dome was later extruded, but it is also possible that the tephra came from a nearby vent that later was the source of the "floating island" lava flow.

\section{"FLOATING ISLAND" LAVA FLOW}

A large andesite flow (locality 90) extends northward from a vent on the northwest flank of the volcano that, before 1980 , was about $0.5 \mathrm{~km}$ southwest of the site of the Goat Rocks dome (frontispiece). The vent was at an altitude between 2,200 and $2,300 \mathrm{~m}$ (C. A. Hopson, unpub. map, 1980). The lava flow is nearly $5 \mathrm{~km}$ long and from 0.2 to $0.7 \mathrm{~km}$ wide. The andesite contains hypersthene, augite, and hornblende and has a $\mathrm{SiO}_{2}$ content of 60.ll percent (Hoblitt and others, 1980). Lawrence (1941) named this the "floating island" lava flow. The "islands" are lithologically dissimilar deposits which overlie the flow; trees grew on them before the 1980 eruptions, whereas the flow itself was barren. The rubbly nature of the deposits that form the "islands" led Lawrence to suggest that they are masses of till carried downslope on a lava flow that had emerged from a vent beneath a debris-laden glacier. My examination of the islands during the 1970's revealed that they are formed by a mixture of fine-grained gray and reddish-gray dacite fragments in a sand and silt matrix. Pumice fragments mixed with the lithic material are mineralogically similar to tephra of layer $T$. These masses occur in several areas and duplicate the arcuate transverse ridge 


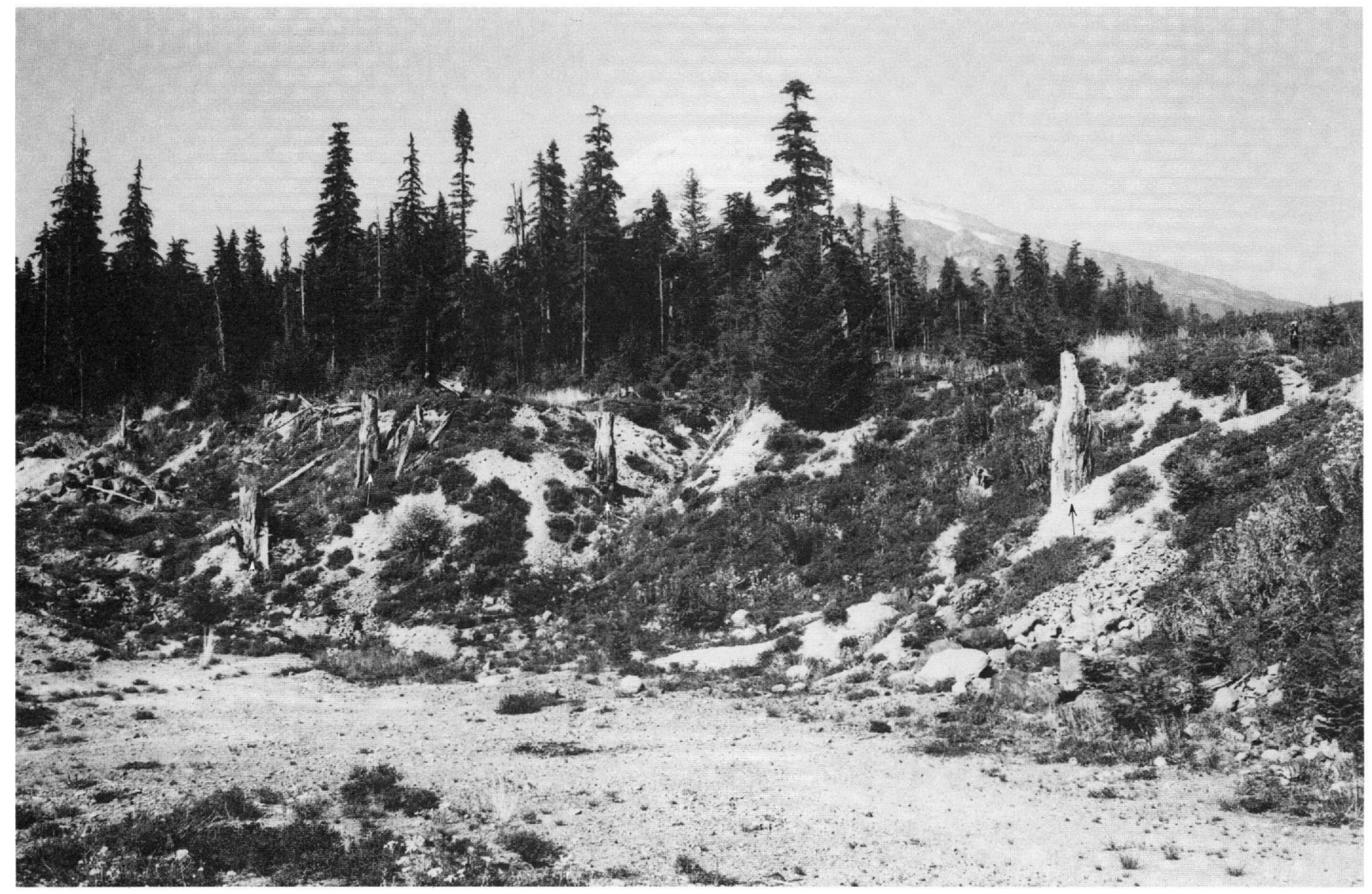

Figure 53.-Lahars of dacite rock debris from the summit dome of Mount St. Helens bury stumps of trees (arrows) at the south base of the volcano (locality 51). This area was buried by fluvial deposits during and after the May 18, 1980, eruption.

pattern of the surface of the lava flow. As Lawrence pointed out, the normally gray rock debris has been altered to bright shades of red where it is in contact with the flow and thus had been baked by the underlying hot lava.

There is little question that the rock debris that forms the islands was carried along on the surface of the lava flow, but the debris probably was deposited on the moving lava flow by several successive avalanches from the flank of the volcano as the lava was being extruded.

The age of the "floating island" lava flow has long been in question. Verhoogen (1937, p. 273) suggested that it is one of the "latest products of volcanic activity at Mount St. Helens" and labeled the flow "1854" on his geologic sketch map. Lawrence $(1954$, p. 59) thought that the flow was erupted before 1838 because of the ages of trees growing on the islands. He noted that tephra erupted about 1800 (layer T) was absent from the lava flow and that therefore the flow is younger. According to Hoblitt (oral commun., 1979), the magnetic direction of the lava flow is consistent with an age between 1800 and 1838 .
The lava flow bears Rhizocarpon sp. lichens that have diameters of as much as $160 \mathrm{~mm}$, similar to the sizes of lichens on lava flows of Kalama age on the southeast side of Mount St. Helens. If the age of the "floating island" lava flow is post-1800, as suggested, an unusually rapid growth rate is thereby implied for Rhizocarpon lichens in this area.

\section{TEPHRA ERUPTED IN 1842}

An explosive eruption of Mount St. Helens in 1842 produced lithic ash (Holmes, 1955; Hoblitt and others, 1980) that fell downwind at least as far as The Dalles, Oreg., $100 \mathrm{~km}$ southeast of the volcano. No other products of this eruption have been recognized at the volcano. The ash eruption probably preceded or accompanied the initial extrusion of the Goat Rocks dome and may have been analogous to repeated eruptions of lithic ash at Mount St. Helens after March 27, 1980, that preceded the initial magmatic eruption on May 18. 


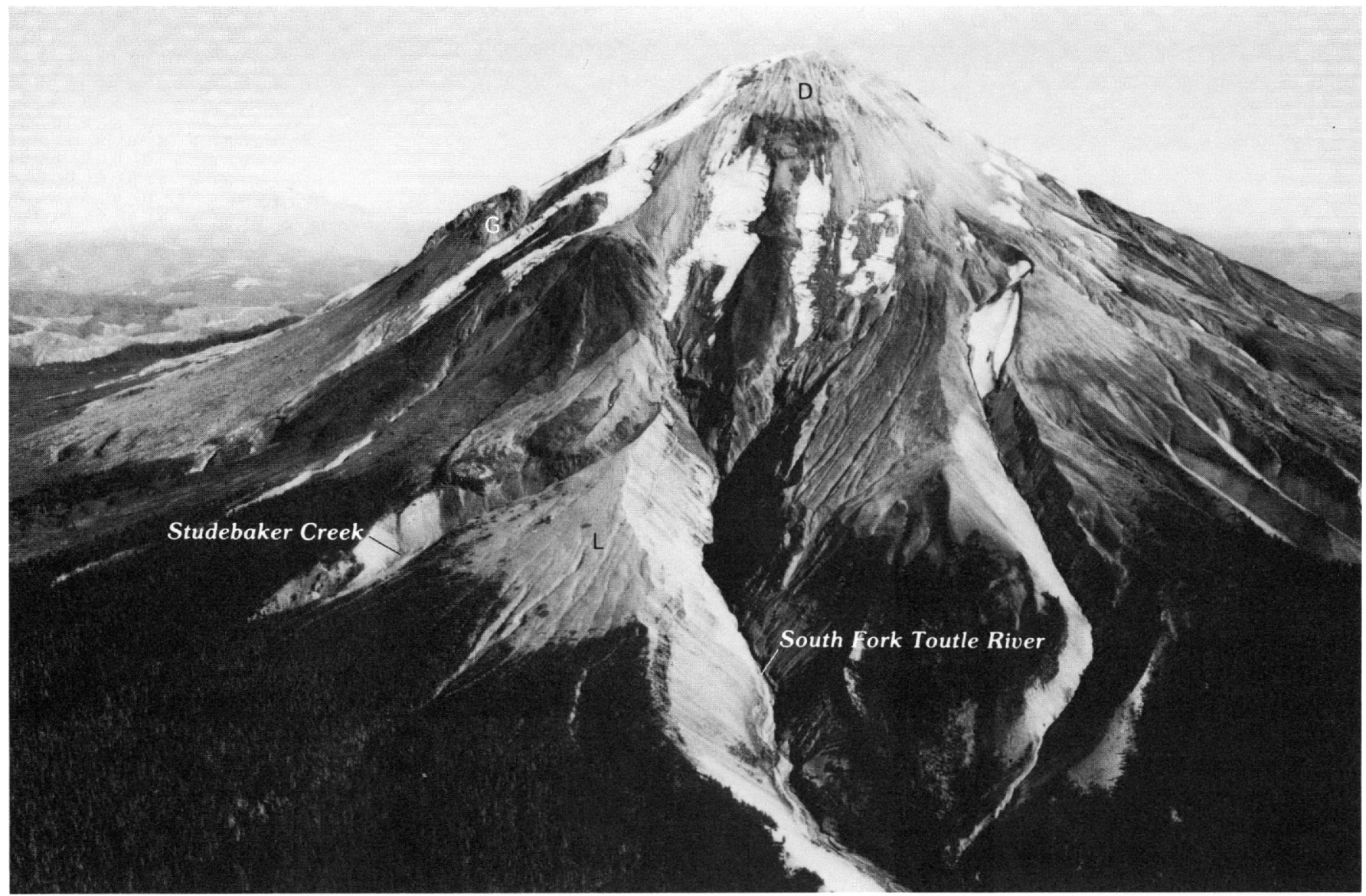

Figure 54.-Aerial view toward the canyon of the South Fork Toutle River on the west side of Mount St. Helens. The triangular area (L) north (left) of the canyon is underlain by lahars of dacite rock debris derived from the summit dome (D). The knob (G) on the north side of the volcano is the Goat Rocks dome. Photograph taken in 1979 by R. P. Hoblitt, U.S. Geological Survey.

\section{GOAT ROCKS DOME}

A dome was extruded $600-700 \mathrm{~m}$ below the summit on the northwest flank of the volcano during the next recorded eruption of the Goat Rocks eruptive period. The rock of the dome is a hypersthene-hornblende dacite that contains small amounts of augite. Its $\mathrm{SiO}_{2}$ content is 63.35 percent (Hoblitt and others, 1980). The Goat Rocks dome was destroyed during the landslide and eruption of May 18, 1980.

A large convex and digitate fan of rock debris extended downslope from Goat Rocks before the 1980 eruptions (frontispiece). The fan was barren above an altitude of about $1,350 \mathrm{~m}$, but below that altitude it bore a sparse pine forest. In detail, the surface of the fan was a complex of shallow gullies and low bouldery ridges, all trending downslope to the north, as well as mounds a meter or two high and a few tens of meters across that represented the ends of individual flowage lobes. At the downslope margin of the fan, fingers of the fan debris with its sparse forest extended into a mature forest growing on older deposits. The fan was littered with large angular and subangular blocks of dacite, many of them prismatically jointed. Verhoogen $(1937$, p. 274) noted that the blocks were in various stages of disaggregation and concluded that the jointing developed after the blocks came to rest. He inferred that their source was at Goat Rocks and concluded that the blocks had been carried downslope by a nuée ardente (pyroclastic flow).

Blocks of dacite on the fan were sampled by R. P. Hoblitt (oral commun., 1979) at three localities for the purpose of determining TRM directions, and thereby possibly proving whether the fan was formed during growth of the dome, or later. The three sites were downslope from the base of Goat Rocks at distances of about $1.1,1.8$, and $2.7 \mathrm{~km}$, and the vertical distances of each locality below the base of the dome were about 530,730 , and $900 \mathrm{~m}$, respectively. The first sample site was in the middle of a lobe of rock debris 1-1.5 m thick 
and a few tens of meters wide that had steep blocky margins. Four samples from this deposit all had random TRM directions; hence, the lobe of debris evidently was formed by a lahar. The second locality was along a downslope-trending bouldery ridge that probably was formed as a levee along the margin of a pyroclastic flow or lahar. All four samples from this locality were from prismatically jointed blocks. The TRM direction of three of these paralleled the earth's present magnetic field, and the fourth was random. The third locality was along another downslope-trending ridge of rock debris. Two samples taken from prismatically jointed blocks at this locality were both oriented. One rock fragment, not prismatically jointed, taken from beneath the ground surface, had a random TRM direction; the results from a fourth sample were inconclusive.

The results of these determinations show that the fan deposits included both material that was hot, when it was emplaced either by pyroclastic flows or lahars carrying hot material, and debris that was cold. The fan deposits clearly were formed during the growth of the Goat Rocks dome, originating as hot avalanches from the flanks of the dacite mass as it was being extruded. Avalanches that moved across snow probably caused melting and were remobilized as lahars.

The exact age of the Goat Rocks dome and associated fan of debris is not known. The fan deposits were younger than tephra layer $T$, which was erupted in A.D. 1800. The oldest tree I found on the fan deposits, which was near the northwest margin, started to grow sometime before 1876 . The trees on the fan were much smaller and younger than trees growing on adjacent, older surfaces, and clearly represented a first-generation forest on the fan deposits. The largest lichen (Rhizocarpon sp.) I found on dacite blocks that littered the fan surface was near timberline and had a diameter of $63 \mathrm{~mm}$. Most lichens on these blocks, however, were no more than $40 \mathrm{~mm}$ in diameter.

Several eyewitness accounts cite some kind of eruptive activity occurring on the northwest or north side of Mount St. Helens during the 1840's and 1850's. Of these accounts, the best documentation is a painting by the Canadian artist Paul Kane, which was based on a sketch he made in March 1847. The painting shows an eruption column rising above a vent on the northwest side of the volcano in the approximate position of Goat Rocks. The start of dome extrusion has not been determined. I infer that the eyewitness accounts and Kane's painting record dome extrusion over a period of many years, intermittently accompanied by emission of ash, steam, and gases which were visible for great distances.

Other accounts of eruptions printed in local newspapers of the mid-1800's place the sites of activity on the south side $(1842,1843-44,1853)$ and the northeast side $(1850,1853)$. Vents associated with these reported eruptions have not been identified.

The last significant eruption of the Goat Rocks period was in 1857, when "volumes of dense smoke and fire" were reported (Frank Balch, quoted by Majors (1980, p. 36). A recent study of old records has reported minor eruptions in 1898, 1903, and 1921 (Majors, 1980, p. 36-41). None of these produced deposits that have been recognized, and probably none were accompanied by juvenile magmatic material.

\section{NATURE AND AGE OF VOLCANISM}

The eruptive period began in 1800 with an explosive eruption of dacite pumice from a vent at or near the site of Goat Rocks, which was followed perhaps as much as several decades later by an andesite lava flow from the same general vent area. The Goat Rocks dacite dome is believed to have been extruded in the 1840's and 1850 's, following an eruption of lithic tephra in 1842. No stratigraphic evidence was found of other explosive activity before or during the formation of the dome. The lithologic sequence of the Goat Rocks eruptive period resembled that of the more complex Kalama eruptive period, which probably was about twice as long as Goat Rocks time.

The Goat Rocks eruptive period followed a dormant interval of 170-210 years and was followed by 123 years of quiescence before the eruptions that began March 27, 1980.

\section{THE FUTURE}

Mount St. Helens has been intermittently active for the last 4,000 radiocarbon years, a time during which most eruptive periods have had lengths on the order of a few decades or a few centuries and have included several kinds of volcanic activity. This pattern suggests that the sporadic activity that began in 1980 will persist for many years if not decades and will include a variety of eruptive behaviors.

Dormant intervals during the last 4,000 years have also lasted a few decades to a few centuries. That time was preceded, however, by an apparent dormant interval of more than 5,000 years, and some intervals during the earlier history of the volcano may have been even longer. When the present period of activity ends, there probably will be no sure way to know whether the next dormant interval will be one of decades, centuries, or millennia.

The modern volcano developed during the Castle Creek, Sugar Bowl, Kalama, and Goat Rocks eruptive 
periods; thus, these periods can be examined for possible models which might suggest the most likely future course of the present eruptive activity. None of these previous periods included a catastrophic lateral blast like that of May 18, 1980; that explosion evidently was an aberration in the eruptive history of Mount St. Helens.

The initial eruptions of Castle Creek time evidently produced one or more andesite lava flows which were followed by eruptions of andesitic tephra; thus, the early part of this period differed from the eruptive period that started in 1980 with dacitic volcanism. The early Castle Creek andesite eruptions were followed by dacitic volcanism which produced tephra, pyroclastic flows, and perhaps the Dog's Head dome. The age of explosive eruptions relative to dome extrusion is not known. The eruptions of dacite were followed by andesite lava flows, and the period ended with the eruption of basaltic tephra and lava flows. If the present period of activity is analogous to the dacitic volcanism of Castle Creek time, andesite and perhaps basalt in the form of lava flows or tephra, or both, would be expected before the volcano becomes dormant again.

The Sugar Bowl eruptive period of about 1,200 years ago was relatively simple; it consisted of the extrusion of a dacite dome without preceding, accompanying, or following tephra eruptions. Explosions that disrupted the dome during its growth seem to have originated within the dome itself. In contrast, the present period of activity began with an explosive tephra eruption; thus it does not seem to be closely analogous to the Sugar Bowl eruptive period.

The Kalama eruptive period began in 1480 with an explosive eruption of dacitic tephra which was followed by a similar eruption in 1482 . In addition to these two voluminous eruptions, other eruptions in early Kalama time produced minor layers of tephra and probably a dacite dome whose disruption caused one or more pyroclastic flows on the southwest side of the volcano. These eruptions were followed by andesite lava flows and pyroclastic flows and a small amount of tephra. During the last part of the period, perhaps in the early part of the 17th century, the volcano again erupted dacite in the form of a dome and pyroclastic flows.

The most recent pre-1980 activity of Mount St. Helens, the Goat Rocks eruptive period, produced voluminous dacitic tephra in 1800 , a lava flow of high silica andesite sometime between 1800 and 1838 , and the Goat Rocks dacite dome probably during the 1840's and 1850's. The explosive eruptions of Mount St. Helens in May, 1980, could be analogous to the tephra eruption that initiated the Goat Rocks period, but the dome extrusion that immediately followed in 1980 differs from the sequence of events during Goat Rocks time.
The variety in kinds and sequences of volcanic activity during the four most recent eruptive periods before 1980 shows that no single pattern of behavior has characterized the volcano. Because of this, there is no assurance that future activity will duplicate that of any period of the past. Nevertheless, the eruptive events of early Kalama time seem to be the closest analog to the present activity. If the current eruptive sequence repeats the events of Kalama time, future volcanic activity will include multiple eruptions of dacite in the form of domes, tephra, and pyroclastic flows, and andesite in the form of lava flows, tephra, and pyroclastic flows, and will continue intermittently for at least a century.

\section{REFERENCES}

Browning, J. M., 1973, Catastrophic rock slide, Mount Huascaran, north central Peru, May 31, 1970: American Association of Petroleum Geologists Bulletin, v. 57, na 7, p. 1335-1341.

Crandell, D. R., 1965, The glacial history of western Washington and Oregon, in Wright, H. E., Jr., and Frey, D. G., eds., The Quaternary of the United States: Princeton, Princeton University Press, p. 341-353.

Crandell, D. R., 1971, Postglacial lahars from Mount Rainier volcana, Washington: U.S. Geological Survey Professional Paper 677, 75 p.

Crandell, D. R., and Hoblitt, R. P., 1986, Lateral blasts at Mount St. Helens and hazard zonation: Bulletin of Volcanology, v. 48, no. 1, p. 27-37.

Crandell, D. R., and Miller, R. D., 1974, Quaternary stratigraphy and extent of glaciation in the Mount Rainier region, Washington: U.S. Geological Survey Professional Paper 847, 59 p.

Crandell, D. R., and Mullineaux, D. R., 1973, Pine Creek volcanic assemblage at Mount St. Helens, Washington: U.S. Geological Survey Bulletin 1383-A, 23 p.

Crandell, D. R., and Mullineaux, D. R., 1978, Potential hazards from future eruptions of Mount St. Helens volcano, Washington: U.S. Geological Survey Bulletin 1383-C, 26 p.

Crandell, D. R., Mullineaux, D. R., and Rubin, Meyer, 1975, Mount St. Helens volcano-Recent and future behavior: Science, v. 187, no 4175, p. 438-441.

Crandell, D. R., Mullineaux, D. R., Rubin, Meyer, Spiker, Elliott, and Kelley, M. L., 1981, Radiocarbon dates from volcanic deposits at Mount St. Helens, Washington: U.S. Geological Survey Open-File Report 81-844, $15 \mathrm{p}$.

Cummans, John, 1981, Chronology of mudflows in the South Fork and North Fork Toutle River following the May 18 eruption, in Lipman, P. W., and Mullineaux, D. R., eds., The 1980 eruptions of Mount St. Helens, Washington: U.S. Geological Survey Professional Paper 1250, p. 479-486.

Fisher, R. V., 1971, Features of coarse grained high concentration fluids and their deposits: Journal of Sedimentary Petrology, v. 41, na. 4. p. 916-927.

1979, Models for pyroclastic surges and pyroclastic flows: Jour nal of Volcanology and Geothermal Research, v. 6, p. 305-318.

Fisher, R. V., and Heiken, Grant, 1982, Mt. Pelé, Martinique May 8 and 20,1902, pyroclastic flows and surges: Journal of Volcanology and Geothermal Research, v. 13, p. 339-371.

Fisher, R. V., Smith, A. L., and Roobol, M. J., 1980, Destruction of St. Pierre, Martinique, by ash-cloud surges, May 8 and 20, 1902: Geology, v. 8, p. 472-476. 
Francis, P. W., Roobol, M. J., Walker, G. P. L., Cobbold, P. R., and Coward, M., 1974, The San Pedro and San Pablo volcanoes of northern Chile and their hot avalanche deposits: Geologische Rundschau, v. 63 , no. 1, p. 357-388.

Greeley, Ronald, and Hyde, J. H., 1972, Lava tubes of the Cave Basalt: Geological Society of America Bulletin, v. 83, p. 2397-2418.

Harris, S. L., 1976, Fire and ice-The Cascade volcanoes: Seattle, The Mountaineers and Pacific Search Books, 316 p.

Hays, J. D., Imbrie, John, and Shackleton, N. J., 1976, Variations in Earth's orbit-Pacemaker of the Ice Ages: Science, v. 194, no. 4270, p. 1121-1132.

Hoblitt, R. P., 1978, Emplacement mechanisms of unsorted and unstratified deposits of volcanic rock debris as determined from paleomagnetically derived emplacement-temperature information: Boulder, University of Colorado $\mathrm{Ph}$. D. thesis, $206 \mathrm{p}$.

Hoblitt, R. P., Crandell, D. R., and Mullineaux, D. R., 1980, Mount St. Helens eruptive behavior during the past 1,500 yr.: Geology, v. 8, p. 555-559.

Hoblitt, R. P., and Kellogg, K. S., 1979, Emplacement temperatures of unsorted and unstratified deposits of volcanic rock debris as determined by paleomagnetic techniques: Geological Society of America Bulletin, v. 90, pt. 1, p. 633-642.

Holmes, K. L., 1955, Mount St. Helens' recent eruptions: The Oregon Historical Quarterly, v. 56, p. 196-210.

Hopson, C. A., 1971, Eruptive sequence at Mount St. Helens, Washington: Geological Society of America Abstracts with Programs, v. 3 , no. 2 , p. 138 .

Hopson, C. A., and Melson, W. G., 1982, Stratigraphy of Mount St. Helens 1980 crater walls: Eos, American Geophysical Union Transactions, v. 63 , no. 45, p. 1144 .

Hyde, J. H., 1970, Geologic setting of Merrill Lake and evaluation of volcanic hazards in the Kalama River Valley near Mount St. Helens, Washington: U.S. Geological Survey Open-File Report, $17 \mathrm{p}$.

1973, Late Quaternary volcanic stratigraphy, south flank of Mount St. Helens, Washington: Seattle, University of Washington $\mathrm{Ph}$. D. thesis, $114 \mathrm{p}$.

1975, Upper Pleistocene pyroclastic-flow deposits and lahars south of Mount St. Helens volcano, Washington: U.S. Geological Survey Bulletin 1383-B, 20 p.

Iida, Kumizi, 1938, The mud flow that occurred near the explosion crater of Mt. Bandai on May 9 and 15, 1938, and some physical properties of volcanic mud: Tokyo University Earthquake Research Institute Bulletin, v. 16, pt. 3, p. 658-681.

Janda, R. J., Scott, K. M., Nolan, K. M., and Martinson, H. A., 1981, Lahar movement, effects, and deposits, in Lipman, P. W., and Mullineaux, D. R., eds., The 1980 eruptions of Mount St. Helens, Washington: U.S. Geological Survey Professional Paper 1250, p. 461-478.

Johnson, A. M., 1965, A model for debris flow: Pennsylvania State University $\mathrm{Ph}$. D. thesis, $232 \mathrm{p}$.

1970, Physical processes in geology: San Francisco, Freeman, Cooper, and Company, $577 \mathrm{p}$.

Lawrence, D. B., 1941, The "floating island" lava flow of Mt. St. Helens: Mazama, v. 23 , no. 12 , p. $56-60$.

1954, Diagrammatic history of the northeast slope of Mt. St. Helens, Washington: Mazama, v. 36, no. 13, p. 41-44.

Lipman, P. W., and Mullineaux, D. R., eds., 1981, The 1980 eruptions of Mount St. Helens, Washington: U.S. Geological Survey Professional Paper 1250, 844 p.

Lowe, D. R., 1976, Grain flow and grain flow deposits: Journal of Sedimentary Petrology, v. 46, no. 1, p. 188-199.

Lucchitta, B. K., 1978, A large landslide on Mars: Geological Society of America Bulletin, v. 89, p. 1601-1609.
Macdonald, G. A., 1975, Hazards from volcanoes, ch. 2, in Bolt, B. A., Horn, W. L., Macdonald, G. A., and Scott, R. F., Geological hazards: New York, Springer Verlag, p. 63-131.

Macdonald, G. A., and Alcaraz, Arturo, 1956, Nuées ardentes of the 1948-1953 eruption of Hibok-Hibok: Bulletin Volcanologique, $v$. 18 , p. $169-178$.

Majors, H. M., 1980, Three newly discovered accounts of activity on Mount St. Helens, 1898, 1903, and 1921: Northwest Discovery, v. 1 , no. 1 , p. $36-41$.

Miller, C. D., 1969, Chronology of neoglacial moraines in the Dome Peak area, north Cascade Range, Washington: Arctic and Alpine Research, v. 1, no. 1, p. 49-66.

Miller, C. D., Mullineaux, D. R., and Hall, M. L., 1978, Reconnaissance map of potential volcanic hazards from Cotopaxi volcano, Ecuador: U.S. Geological Survey Miscellaneous Investigations Map I-1072.

Mullineaux, D. R., 1986, Summary of pre-1980 tephra-fall deposits erupted from Mount St. Helens, Washington State, U.S.A.: Bulletin of Volcanology, v. 48, no. 1, p. 17-26.

Mullineaux, D. R., and Crandell, D. R., 1962, Recent lahars from Mount St. Helens, Washington: Geological Society of America Bulletin, v. 73 , no. 7 , p. 855-869.

1981, The eruptive history of Mount St. Helens, in Lipman, P. W., and Mullineaux, D. R., eds., The 1980 eruptions of Mount St. Helens, Washington: U.S. Geological Survey Professional Paper 1250, p. 3-15.

Mullineaux, D. R., Hyde, J. H., and Rubin, Meyer, 1972, Preliminary assessment of upper Pleistocene and Holocene pumiceous tephra from Mount St. Helens, southern Washington [abs.]: Geological Society of America Abstracts with Programs, v. 4, no. 3, p. 204-205.

1975, Widespread late glacial and postglacial tephra deposits from Mount St. Helens volcano, Washington: U.S. Geological Survey Journal of Research, v. 3, no. 3, p. 329-335.

Mullineaux, D. R., Wilcox, R. E., Ebaugh, W. F., Fryxell, Roald, and Rubin, Meyer, 1978, Age of the last major scabland flood of the Columbia Plateau in eastern Washington: Quaternary Research, v. 10, p. $171-180$.

Mundorff, M. J., 1984, Glaciation in the lower Lewis River basin, southwestern Cascade Range, Washington: Northwest Science, v. 58, p. 269-281.

Munsell Color Company, 1954, Munsell soil color charts: Baltimore, Maryland.

Murai, Isamu, 1963, A brief note on the eruption of the Tokachi-dake volcano of June 29 and 30, 1962: Tokyo University Earthquake Research Institute Bulletin, v. 41, pt. 1, p. 185-208.

Newhall, C. G., 1982, A prehistoric debris avalanche from Mount St. Helens [abs.]: Eos, American Geophysical Union Transactions, v. 63 , no. 45 , p. 1141 .

Okazaki, Rose, Smith, H. W., Gilkeson, R. A., and Franklin, Jerry, 1972 , Correlation of West Blacktail ash with pyroclastic layer $T$ from the 1800 A.D. eruption of Mount St. Helens: Northwest Science, v. 46, p. 77-89.

Pearson, G. W., and Stuiver, Minze, 1986, High-precision calibration of the radiocarbon time scale, 500-2500 BC: Radiocarbon, v. 28,, no. 2B, p. 839-862.

Plafker, George, and Ericksen, G. E., 1978, Nevados Huascarán avalanches, Peru, in Rockslides and avalanches, 1, natural phenomena: New York, Elsevier Scientific Publishing Company, p. 277-314.

Plafker, George, Ericksen, G. E., and Concha, J. F., 1971, Geological aspects of the May 31,1970, Peru earthquake: Seismological Society of America Bulletin, v. 61, no. 3, p. 543-578.

Rodine, J. D., and Johnson, A. M., 1976, The ability of debris, heavily freighted with coarse clastic materials, to flow on gentle slopes: Sedimentology, v. 23, p. 213-234. 
Schmincke, H. U., 1967, Graded lahars in the type sections of the Ellensburg Formation, south-central Washington: Journal of Sedimentary Petrology, v. 37, no. 2, p. 438-448.

Scrivenor, J. B., 1929, The mudstreams ("lahars") of Gunong Keloet in Java: The Geological Magazine, v. 66, no. 10, p. $433-434$.

Shapiro, Leonard, 1975, Rapid analysis of silicate, carbonate, and phosphate rocks-Revised edition: U.S. Geological Survey Bulletin 1401, 76 p.

Smith, H. W., and Okazaki, Rose, 1977, Electron microprobe analysis of glass shards from tephra assigned to set W, Mount St. Helens, Washington: Quaternary Research, v. 7, p. 207-217.

Sparks, R. S. J., 1976, Grain size variations in ignimbrites and implications for the transport of pyroclastic flows: Sedimentology, v. 23, p. $147-188$.

Sparks, R. S. J., and Wilson, Lionel, 1976, A model for the formation of ignimbrite by gravitational column collapse: Geological Society of London Journal, v. 132, p. 441-451.

Stuiver, Minze, 1978, Radiocarbon timescale tested against magnetic and other dating methods: Nature, v. 273, p. 271-274.

Stuiver, Minze, and Pearson, G. W., 1986, High-precision calibration of the radiocarbon time scale, AD 1950-500 BC.: Radiocarbon, v. 28 , no. $2 B$, p. $805-838$.

Suess, H. E., 1970, Bristlecone-pine calibration of the radiocarbon time scale 5200 B.C. to the present [with discussion], in Olsson, I. U., ed., Radiocarbon variations and absolute chronology: Nobel Symposium, 12th, Uppsala, 1969, Proceedings, New York, John Wiley, p. $303-311$.

Tada, Fumio, and Tsuya, Hiromichi, 1927, The eruption of the Tokachidake Volcano, Hokkaido, on May 24, 1926: Tokyo University Earthquake Research Institute Bulletin, v. 2, p. 49-84 [English summary, p. 49-50].
Taylor, G. A., 1958, The 1951 eruption of Mount Lamington, Papua: Australia Bureau of Mineral Resources, Geology and Geophysics Bulletin 38, $100 \mathrm{p}$.

Varnes, D. J., 1958, Landslide types and processes, ch. 3, in Eckel, E. B., ed., Landslides and engineering practice: National Research Council, Highway Research Board Special Report 29, p. 20-47.

Verhoogen, Jean, 1937, Mount St. Helens-A recent Cascade volcano: California University Department of Geological Sciences Bulletin, v. 24 , no. 9 , p. 263-302.

Waldron, H. H., 1967, Debris flow and erosion control problems caused by the ash eruptions of Irazú Volcano, Costa Rica: U.S. Geological Survey Bulletin 1241 I, p. I1-I37.

Williams, Howel, 1960, Volcanic history of the Guatemalan Highlands: California University Publications of Geological Sciences, v. 38. no. 1, p. 1-87.

Wohletz, K. H., and Sheridan, M. F., 1979, A model of pyroclastic surge: Geological Society of America Special Paper 180. p. 177-194.

Wolf, Teodoro, 1878, Der Cotopaxi und seine letzte eruption am 26 Juni 1877: Neues Jahrbuch fur Mineralogie Abhandlungen, p. 113-167.

Wright, J. V., and Walker, G. P. L., 1981, Eruption, transport, and deposition of ignimbrite-A case study from Mexico: Journal of Volcanology and Geothermal Research, v. 9, p. 111-131.

Yamaguchi, D. K., 1982, New tree ring dates for recent eruptions of Mount St. Helens: American Quaternary Association, Seventh Biennial Conference, Program and Abstracts, p. 183.

1983, New treering dates for recent eruptions of Mount St. Helens: Quaternary Research, v. 20, p. 246-250.

1985, Tree-ring evidence for a two-year interval between recent prehistoric explosive eruptions of Mount St. Helens: Geology, v. 13 , p. $554-557$. 



\section{APPENDIX A}

Eleven samples collected for chemical analysis during this study, and reported below, supplement analyses of samples collected by others, most of which are from volcanic products of post-Pine Creek age. Some of these other analyses were reported by Hoblitt, Crandell, and Mullineaux (1980). All the analyses shown here were made on samples of what is believed to be juvenile magmatic material. 



\section{CHEMICAL ANALYSES}

Chemical analyses, in percent, of some rocks erupted at Mount St. Helens

[Rapid rock analyses (columns 1-7) were performed in the laboratories of the U.S. Geological Survey by C. Jones using the method described under "single solution" in U.S. Geological Survey Bulletin 1401 (Shapiro, 1975). Chemical analyses by X-ray spectroscopy (columns 8-11) by J. E. Taggart. nd, not determined]

\begin{tabular}{|c|c|c|c|c|c|c|c|c|c|c|c|}
\hline Sample Nos ${ }^{1}$ & 1 & 2 & 3 & 4 & 5 & 6 & 7 & 8 & 9 & 10 & 11 \\
\hline$\ldots \ldots \ldots \ldots \ldots \ldots \ldots \ldots \ldots \ldots$ & 66.7 & 62.6 & 62.6 & 67.2 & 64.4 & 64.6 & 64.2 & 57.8 & 63.3 & 62.5 & 60.8 \\
\hline $\mathrm{Al}_{2} \mathrm{O}_{3}$ & 16.3 & 18.0 & 18.3 & 17.6 & 17.3 & 17.6 & 17.3 & 16.8 & 17.1 & 17.4 & 17.9 \\
\hline $\mathrm{Fe}_{2} \mathrm{O}_{3}$ & 1.4 & 1.7 & 1.6 & 1.6 & 1.3 & 2.1 & 2.4 & & & & \\
\hline $\mathbf{F e O} \ldots \ldots \ldots \ldots \ldots$ & 2.1 & 3.2 & 3.2 & 2.1 & 2.8 & 2.4 & 1.9 & 8.74 & 4.63 & 5.45 & 5.65 \\
\hline $\mathrm{MgO}$ & 1.4 & 2.2 & 2.2 & 1.4 & 2.2 & 1.9 & 1.9 & 2.36 & 1.71 & 1.71 & 2.47 \\
\hline $\mathrm{CaO}$ & 3.7 & 4.7 & 4.8 & 4.2 & 4.9 & 4.6 & 4.5 & 5.99 & 4.55 & 5.03 & 5.68 \\
\hline$\ldots \ldots \ldots \ldots$ & 4.3 & 4.5 & 4.4 & 4.7 & 4.4 & 4.6 & 4.9 & 4.54 & 4.39 & 4.39 & 4.41 \\
\hline 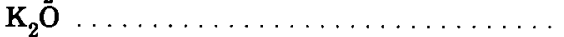 & 1.4 & 1.3 & 1.2 & 1.4 & 1.3 & 1.3 & 1.5 & 1.26 & 1.47 & 1.46 & 1.20 \\
\hline 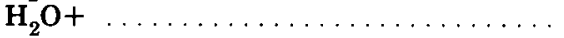 & 1.9 & 1.3 & 1.5 & .33 & .82 & .10 & .05 & & & & \\
\hline $\mathrm{H}_{2}^{2} \mathrm{O}-$ & .39 & .70 & .57 & .17 & .59 & .16 & .11 & .04 & 1.35 & .59 & .75 \\
\hline $\mathrm{TiO}_{2}$ & .55 & .74 & .73 & .53 & .67 & .64 & .69 & 1.54 & .67 & .82 & .71 \\
\hline $\mathrm{P}_{2} \mathrm{O}_{5}$ & .15 & .25 & .28 & .15 & .15 & .17 & .19 & .29 & .15 & .18 & .17 \\
\hline MnO & .03 & .07 & .06 & .05 & .05 & .04 & .03 & .13 & .07 & .08 & .09 \\
\hline$\ldots \ldots \ldots \ldots \ldots$ & .02 & .02 & .03 & .03 & .03 & .03 & .03 & nd & nd & nd & nd \\
\hline Totals $\ldots \ldots \ldots \ldots \ldots$ & 100.34 & 101.28 & 101.47 & 101.46 & 101.91 & 100.24 & 99.7 & 99.49 & 99.39 & 99.61 & 99.83 \\
\hline
\end{tabular}

${ }^{1}$ Samples for chemical analysis were obtained from the following locations:

1. Pumice clast from pyroclastic-flow deposit of Ape Canyon age at locality 16. Deposit radiocarbon dated as $>42,000$ years old.

2. Pumice clast from pyroclastic-flow deposit of Cougar age at locality 46. Deposit radiocarbon dated as 20,350 \pm 350 years old.

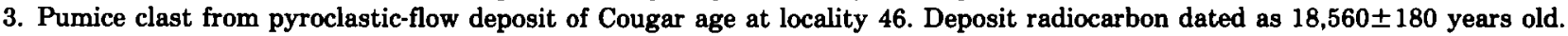

4. Prismatically jointed block of nonvesicular rock from pyroclastic-flow deposit of pre-S Swift Creek age at locality 47 (unit 6 in measured section 1).

5. Prismatically jointed block of nonvesicular rock from pyroclastic-flow deposit of post-S, pre-J Swift Creek age at locality 12.

6. Prismatically jointed block of nonvesicular rock from pyroclastic-flow deposit of Smith Creek age at locality 10 (unit 8 in measured section 5).

7. Prismatically jointed block of nonvesicular rock from pyroclastic-flow deposit of Pine Creek age at locality 33 (unit 7 in measured section 6).

8. Andesite lava flow of Castle Creek age below tephra layer Bh in Castle Creek valley at locality 85 (unit 1 in measured section 10).

9. Pumice clast from pyroclastic-flow deposit of Castle Creek age above tephra layer Bh in Castle Creek valley at locality 85 (unit 4 in measured section 10).

10. Prismatically jointed block of nonvesicular rock from pyroclastic-surge deposit of Castle Creek age in Ape Canyon at locality 18.

11. Pumice clast from pyroclastic-flow deposit of late Kalama age in Castle Creek valley at locality 82 . Deposit radiocarbon dated as $350 \pm 60$ years old.

${ }^{2} \mathrm{SiO}_{2}$ percentages shown here are somewhat lower than those reported on the same samples by Mullineaux and Crandell (1981, p. 9), which were calculated water free. 



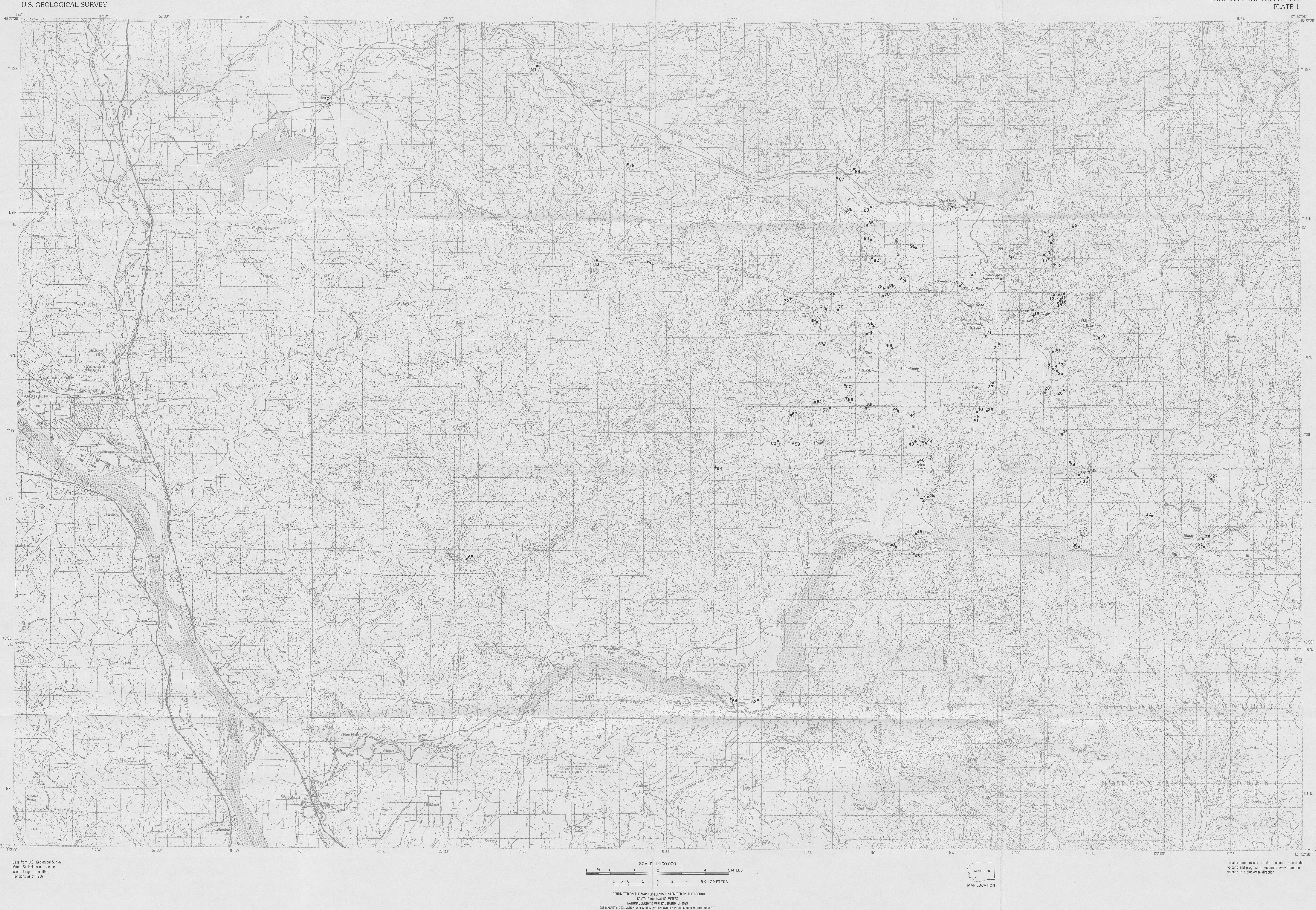

MAP OF MOUNT ST. HELENS AND VICINITY, WASHINGTON, SHOWING LOCALITIES REFERRED TO IN THE TEXT 
